\author{
UNIVERSIDADE DE SÃO PAULO \\ FACULDADE DE FILOSOFIA, LETRAS E \\ CIÊNCIAS HUMANAS \\ DEPARTAMENTO DE LETRAS MODERNAS \\ PROGRAMA DE PÓS-GRADUAÇÃO EM LÍNGUA, \\ LITERATURA E CULTURA ITALIANAS
}

Quézea Regina Albolea Mastelaro

\title{
ANÁLISE DE MATERIAIS E PROPOSTAS DE CURSOS PARA O ENSINO DO ITALIANO JURÍDICO
}

Versão corrigida

São Paulo

2014 


\author{
UNIVERSIDADE DE SÃO PAULO \\ FACULDADE DE FILOSOFIA, LETRAS E \\ CIÊNCIAS HUMANAS \\ DEPARTAMENTO DE LETRAS MODERNAS \\ PROGRAMA DE PÓS-GRADUAÇÃO EM LÍNGUA, \\ LITERATURA E CULTURA ITALIANAS
}

Quézea Regina Albolea Mastelaro

\title{
ANÁLISE DE MATERIAIS E PROPOSTAS DE CURSOS PARA O ENSINO DO ITALIANO JURÍDICO
}

Dissertação apresentada ao Programa de PósGraduação em Língua, Literatura e Cultura Italianas do Departamento de Letras Modernas da Faculdade de Filosofia, Letras e Ciências Humanas da Universidade de São Paulo, para a obtenção do título de Mestre

Área de Concentração: Língua, Literatura e Cultura Italianas

Orientadora: Prof ${ }^{a}$. Dra. Maria Cecilia Casini

\author{
São Paulo
}


Nome: MASTELARO, Quézea Regina Albolea

Título: Análise de materiais e propostas de cursos para o ensino do italiano jurídico

Dissertação apresentada ao Programa de Pós-Graduação em Língua, Literatura e Cultura Italianas do Departamento de Letras Modernas da Faculdade de Filosofia, Letras e Ciências Humanas da Universidade de São Paulo, para a obtenção do título de Mestre

Aprovada em:

Banca examinadora

Prof. Dr. Instituição:

Julgamento: Assinatura:

Prof. Dr. Instituição:

Julgamento: Assinatura:

Prof. Dr. Instituição:

Julgamento: Assinatura: 
$12712 \mathrm{~N}$

VERSÃO CORRIGIDA

O Exemplar original encontra-se no CAP. (CAPH. Centro de Apoio à Pesquisa en

De acoide, Profe. Ire. Mlecilia Casici 
A meu marido Claudemir, pela paciência e pelo apoio. Aos meus queridos filhos Gian Lucca e Gabriel, e a toda a minha família. 


\section{AGRADECIMENTOS}

A Deus, que me deu condições para a concretização deste trabalho.

A meus pais, que sempre me socorreram nos momentos difíceis da minha vida. A meu marido Claudemir e aos meus filhos Gian Lucca e Gabriel pela compreensão e apoio.

Às minhas irmãs e sobrinhas, que sempre me alegraram nos momentos de preocupação.

Ao CNPQ pelo financiamento da minha pesquisa.

À minha orientadora Maria Cecilia Casini, pelo incentivo e por acreditar no meu trabalho.

À diretoria da $\mathrm{OAB}$ - Jundiaí e aos alunos que frequentaram o curso de Italiano para Juristas. Obrigada a Patrícia, Andréa, Roseli, Inês e José Francisco

Aos meus queridos alunos, que se tornaram meus amigos, Inês e José Francisco, pelo apoio nas últimas horas da pesquisa.

À professora Ângela Zucchi, pelos conselhos no exame de qualificação e pela gentileza e atenção na coordenação dos cursos da São Francisco.

À professora Olga Mordente pelos valiosos conselhos no exame de qualificação.

Ao professor Otávio Pinto e Silva juntamente com a professora Ana Maria Nusdeo, por terem apoiado a nossa ideia.

À cara Daniela Aparecida Vieira, por ter me socorrido e ajudado, sempre muito disponível e atenciosa.

À minha amiga Maria Eugênia Savietto por ouvir meus desabafos.

À Daniele Fonseca pela ajuda com o idioma inglês. 
Aos alunos que frequentaram o curso de Italiano para Juristas da São Francisco, principalmente àqueles que terminaram o segundo módulo. Muito obrigada a Guilherme Grise, José Guilherme Fraga, Rafael Meirelles, Tamiris Britzki, Ana Laura Pongeluppi, Ana Paula Castelhano, Ana Paula Ribeiro, Eliegi Tebaldi, Henrique Volpini, Isabela Sperandio, João Paulo Guerra, Lara Veronese, Marcelo Delbim, Rafael Viotti, Regina Cirino e Cristiano Camargo. 


\section{RESUMO}

MASTELARO, Q.R.A. Análise de materiais e propostas de cursos para o ensino do italiano jurídico. 2014. 260 f. Dissertação (Mestrado) - Faculdade de Filosofia, Letras e Ciências Humanas da Universidade de São Paulo, São Paulo, 2013.

O presente trabalho tem por objetivo analisar a metodologia aplicada ao ensino do italiano em contextos específicos, mais precisamente, a linguagem técnica adotada no âmbito profissional jurídico. Para alcançar essa finalidade, primeiramente, analisamos os manuais didáticos de italiano jurídico disponíveis no Brasil e destinados a um público adulto que já tenha conhecimentos básicos do idioma e sinta a necessidade de aprofundá-los por motivos pessoais, profissionais, acadêmicos etc. Além de fazer essa análise, preparamos e ministramos cursos de italiano jurídico para três grupos: um de estudantes que têm o perfil indicado nesses livros didáticos, e dois de alunos iniciantes. Nosso intuito ao propor tais cursos consistia em tentar mostrar que, se os aprendizes fazem parte do "mundo jurídico", eles conseguem desenvolver o léxico específico ao mesmo tempo em que conseguem aprender/adquirir as estruturas básicas da língua italiana. Nas aulas ministradas, utilizamos um dos manuais didáticos de italiano jurídico e, também, um livro didático voltado para o público geral, entretanto não nos restringimos ao uso desses materiais, isto é, elaboramos e propusemos novas atividades. Os cursos foram avaliados pelos alunos por meio de questionários. Com base na análise da utilização dos materiais mencionados e das atividades propostas bem como nas respostas dos discentes, chegamos a algumas conclusões quanto à abordagem de ensino do italiano jurídico.

Palavras-chave: ensino de italiano, análise de materiais, fins específicos, italiano jurídico. 


\begin{abstract}
MASTELARO, Q.R.A. Analysis of materials and courses used to teach legal Italian. 2014. 260 f. Dissertation (Master's degree) - Faculty of Philosophy, Languages and Literature, and Human Sciences of the University of São Paulo, São Paulo, 2013.

This dissertation aims at analyzing the methodology applied to teaching Italian for specific purposes, focusing on the technical language used in the legal setting. To reach this goal, we first analyzed educational materials used to teach legal Italian in Brazil which are targeted at adults with basic language skills who want to enhance those skills due to personal, academic or professional needs. We also prepared and taught Italian classes to three distinct groups: a group of students whose profile matched the target audience for those educational materials and two groups of beginners. Our goal was to show that, if beginners have a legal background, they can develop the specific legal vocabulary at the same time as they learn/acquire the basic structures of the Italian language. In our classes, we also used one of the Legal Italian teaching manuals and a book used to teach students in general. However, we did not restrict ourselves to the use of these materials, but rather prepared and used new activities in the classes. These Italian courses were assessed by students through surveys. Based on the analysis of the materials used in classes as well as the activities proposed, we reached some conclusions as to the approach to be used in teaching legal Italian courses.
\end{abstract}

Keywords: Italian language teaching, educational material analysis, specific purposes, legal Italian. 


\section{RIASSUNTO}

MASTELARO, Q.R.A. Analisi di materiali e proposte di corsi per l'insegnamento dell'italiano giuridico. 2014. 260 p. Tesi (Master) - Facoltà di Filosofia, Lettere e Scienze Umane dell' Università di San Paolo, San Paolo, 2013.

Questo studio si prefigge di esaminare la metodologia usata nell'insegnamento dell'italiano in contesti specifici, e, più precisamente, il linguaggio tecnico adottato nell'ambito giuridico. A tal fine, abbiamo analizzato in primo luogo i libri didattici italiani disponibili in Brasile e destinati ad un pubblico adulto già provvisto di una conoscenza di base della lingua italiana, e che senta il bisogno di approfondirne lo studio per motivi personali, professionali, di studio ecc. Oltre a questa analisi, abbiamo tenuto dei corsi di italiano giuridico a tre gruppi di discenti: il primo a studenti rispondenti ai requisiti richiesti nei libri di testo utilizzati, gli altri due a studenti principianti. Con questi corsi abbiamo cercato di dimostrare che studenti di materie giuridiche possono sviluppare il lessico specifico attinente mentre imparano / acquisiscono le strutture di base della lingua italiana. Durante le lezioni, oltre a utilizzare uno dei suddetti libri di italiano giuridico e un manuale rivolto al pubblico in generale, abbiamo anche preparato e proposto attività nuove. I corsi sono stati valutati dagli studenti grazie a questionari finali. In base all'analisi dell'uso di tali materiali, delle attività proposte, delle risposte degli studenti, siamo arrivati ad alcune conclusioni sull'insegnamento della lingua giuridica italiana.

Parole-chiave: insegnamento dell'italiano, analisi di materiali, scopi specifici, italiano giuridico. 


\section{LISTA DE GRÁFICOS}

Gráfico 1- Idade dos alunos................................................................115

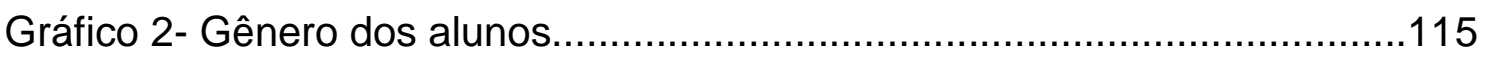

Gráfico 3- Formação dos discentes.......................................................116

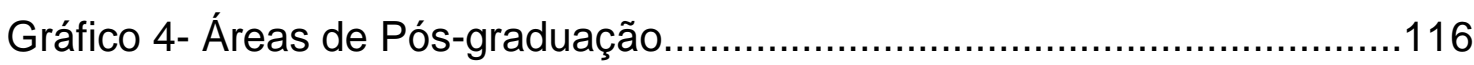

Gráfico 5- Alunos que estudaram anteriormente a língua italiana..................117

Gráfico 6- Nível dos alunos.................................................................118

Gráfico 7- Ênfase dos alunos no curso...................................................118

Gráfico 8- Expectativas dos alunos em relação ao curso.................................119

Gráfico 9- Interesse em relação ao grau de instrução.......................................120

Gráfico 10- Nível de conhecimento dos alunos (primeiro questionário)..........125

Gráfico 11- Nível dos alunos de acordo com o teste ....................................125

Gráfico 12- Final do primeiro módulo. Expectativas iniciais alcançadas..........160

Gráfico 13- Opinião sobre o livro Italiano per giuristi......................................161

Gráfico 14- Impressões sobre o livro Espresso A1.....................................161

Gráfico 15- Atividade mais interessante do curso ......................................162

Gráfico 16- Atividade menos interessante do curso.....................................162

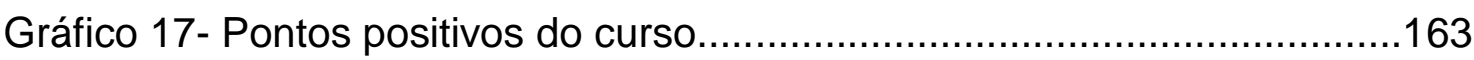

Gráfico 18- Pontos negativos do curso …………………....................... 163

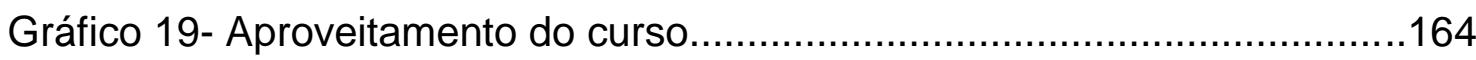

Gráfico 20- Críticas ou sugestões sobre o curso........................................165

Gráfico 21- Nota dos alunos quanto ao próprio desempenho no curso..........198

Gráfico 22- Aspecto que, segundo os estudantes, melhorou.........................198 
Gráfico 23- Aspectos a serem mais bem trabalhados durante o curso.

Gráfico 24- Maior dificuldade dos alunos durante as aulas.

199

Gráfico 25- Interessados em continuar o curso ............................................200

Gráfico 26- Relação entre o tempo e o alcance das expectativas..................200 


\section{SUMÁRIO}

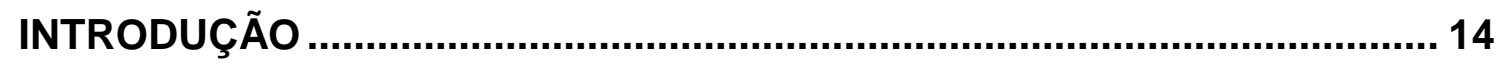

1- O ESTUDO DO ITALIANO COM FINS ESPECÍFICOS. O ITALIANO

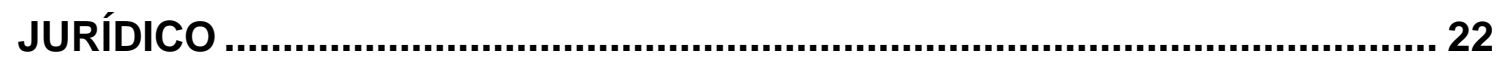

1.1- EVOLUÇÃO HISTÓRICA do ITALIANO: OS PRIMEIROS TEXTOS JURÍDICOS .... 22

1.2- DEFINIÇÕES DO CONCEITO DE LÍNGUAS COM FINS ESPECífICOS POR AUTORES

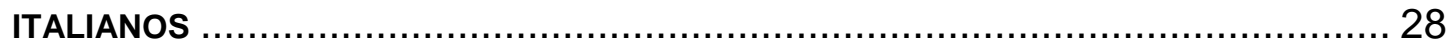

1.3- As LíNGUAS COM FINS ESPECÍFICOS NA ITÁLIA: ALGUMAS PESQUISAS ........... 34

1.4- O ESTUDO DE LÍNGUAS COM FINS ESPECíFICOS NO BRASIL ......................... 37

1.6- UMA VISÃo GERAL E PROPOSTAS DE TRABALHO …................................53

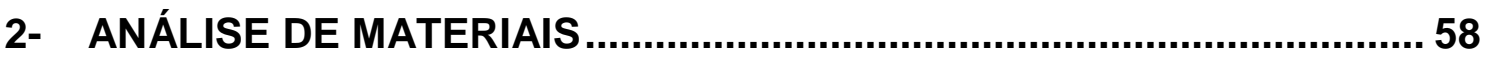

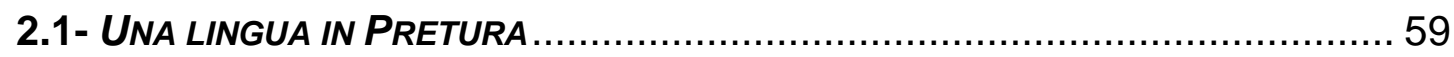

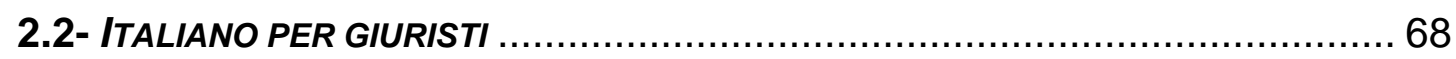

2.3- ELOGIO DEI GIUDICI SCRITTO DA UN AVVOCATO....................................... 74

2.4- ESPRESSO A1 - CORSO DI ITALIANO................................................... 75

3- PROPOSTAS DE CURSOS DE ITALIANO JURÍDICO.............................. 77

3.1- CuRso de Italiano PaRA JuRistas na OAB- Jundiaí............................... 77

3.2- Curso de Italiano para JuRIStas na Faculdade de Direito da

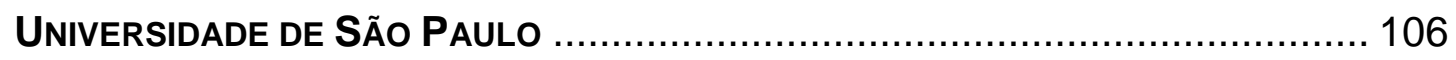

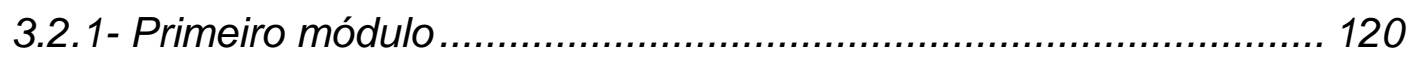

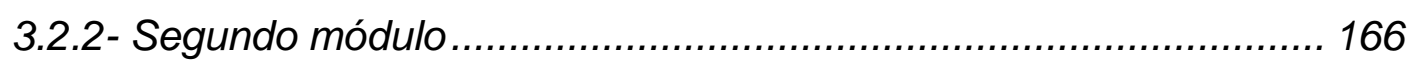

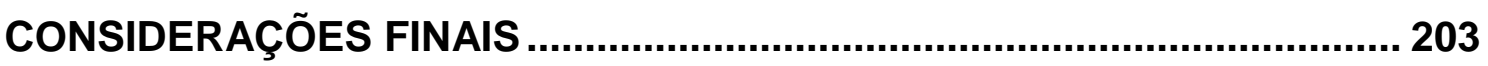

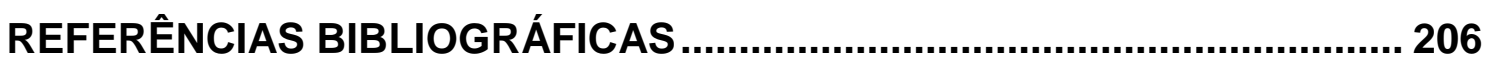

APÊNDICES

APÊNDICE A- Questionário respondido pelos alunos ao final do curso da

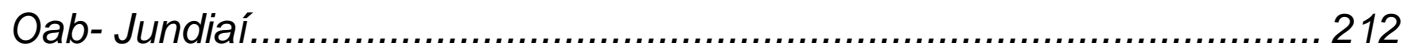

APÊNDICE B-Prova de compreensão de textos realizada com os alunos

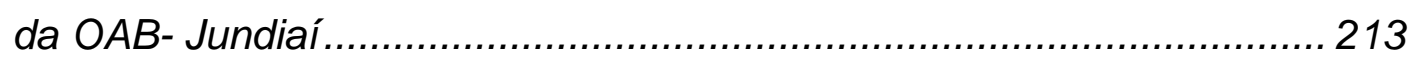


APÊNDICE C- Atividade de compreensão escrita realizada com os alunos da OAB- Jundiaí a partir de um capítulo do livro Le perfezioni provvisorie de Gianrico Carofiglio, p. 100 a 109............................................... 215 APÊNDICE D- Questionário respondido pelos alunos no início do primeiro módulo do curso da São Francisco- USP 219 APÊNDICE E- Teste aplicado para avaliar o nível dos alunos do primeiro módulo do Curso da Faculdade de Direito- USP 220 APÊNDICE F- Questionário respondido ao final do primeiro módulo do curso da São Francisco- USP 228 APÊNDICE G- Questionário respondido ao final do segundo módulo do curso da São Francisco- USP. 229 APÊNDICE H - Termo de autorização do aluno do Curso de Italiano Para Juristas 230

ANEXOS 231

ANEXO A- Trabalho apresentado por uma aluna do grupo de segundafeira (primeiro módulo do curso da São Francisco) 231

ANEXO B- Trabalho apresentado por um aluno do grupo de sábado (primeiro módulo do curso da São Francisco).

ANEXO C-Alguns resumos do grupo de sábado (segundo módulo do curso da São Francisco) 253 ANEXO D-Alguns resumos do grupo de segunda-feira (segundo módulo do curso da São Francisco) 255 


\section{INTRODUÇÃO}

Ao iniciar um curso de língua estrangeira, pode-se notar que, em alguns casos, o aluno não tem uma ideia muito clara quanto aos motivos que o levam a estudar um idioma e quanto à importância da sua participação na aprendizagem. As pessoas, em geral, procuram um curso de línguas simplesmente por quererem aprender um idioma estrangeiro, sem nenhuma exigência específica; às vezes, simplesmente, por lazer ou para aprender algo novo e manter o cérebro ativo. No entanto, em alguns casos, os discentes já chegam com um objetivo específico pré-definido e, nem sempre, encontram o curso que atende as suas necessidades; resta, assim, uma lacuna na sua aprendizagem, que, dificilmente, poderá ser preenchida:

No contexto de ensino de língua estrangeira, uma das perguntas quase nunca feitas pelos pesquisadores $e$ professores é: "Por que é que os alunos querem aprender uma língua estrangeira?" Não é difícil adivinhar o porquê de tamanho descaso e desinteresse em saber algo que com certeza deveria nortear a elaboração de currículos e conteúdos curriculares, a adoção de metodologias apropriadas e a fixação de metas a ser alcançadas. O simples fato é que, com raríssimas exceções, sempre se pensou que só pode haver um único motivo para alguém querer aprender uma língua estrangeira: o acesso a um mundo melhor. (RAJAGOPALAN, 2003)

No caso de alunos que procuram um curso de italiano com fins específicos voltado para a linguagem do Direito, podemos dizer que o principal objetivo é compreender textos jurídicos, além de desenvolver a linguagem escrita e oral. Por esse motivo, o professor, além de possuir conhecimentos de língua, deve ter, também, noções da linguagem usada no âmbito jurídico. É 
importante que o docente adote uma metodologia e materiais adequados, que correspondam às expectativas dos alunos; além disso, é necessário que ele tenha uma postura reflexiva quanto aos motivos que levam os estudantes a procurarem um curso de língua estrangeira com fins específicos.

Por ser bacharel em Direito e docente de italiano há vários anos, a autora notou, ao longo do tempo, várias mudanças no perfil dos alunos que procuram aulas de italiano. Essas mudanças ocorreram, a nosso ver, principalmente por influência da abertura econômica do Brasil para os mercados internacionais, ocasionando, desse modo, uma crescente demanda no mercado de trabalho contemporâneo, especialmente em nível internacional. Há, portanto, cada vez mais exigências para que profissionais atuantes se especializem, e uma delas é que tenham conhecimentos específicos de idiomas voltados para diferentes áreas de trabalho, tais como: as áreas técnico-científicas, a de negócios e a jurídica.

O nosso foco de pesquisa refere-se à especificidade da linguagem jurídica, já que a autora, como já mencionado, possui formação em Direito agregada ao conhecimento da língua italiana. Ressaltamos que a aprendizagem desse idioma resultou do fato de a autora ter morado em Pescara (Itália) de 1994 a 1996 e de ter frequentado muitos cursos de língua italiana e de didática dessa língua, o que contribuiu para o aperfeiçoamento da sua formação docente.

Um dos pontos que queremos destacar diz respeito ao fato de que as sociedades são reguladas pelo Direito, e isso se reflete na língua por meio da escrita, influenciando também a linguagem falada. 
Além disso, destacamos que um dos primeiros documentos escritos em língua italiana foi exatamente um documento jurídico. Abordaremos esse curioso fato concernente à origem da língua italiana no primeiro capítulo do presente trabalho.

A origem do Direito Brasileiro é romana, o que leva os estudiosos do âmbito jurídico à leitura de textos escritos em italiano. Muitos textos históricos ou atuais não possuem tradução para o português e, por vezes, quando se encontram traduzidos por pessoas inexperientes, perdem a qualidade do conteúdo. A nosso ver, os especialistas precisam desenvolver, além da habilidade de leitura e compreensão de textos, a habilidade oral e escrita no idioma para poderem argumentar com propriedade nas suas relações jurídicas, atuando nas soluções de litígios, no Direito Público ou no Direito Privado, tanto no âmbito jurídico como fora dele.

No Brasil, notamos um interesse cada vez maior pela importação e exportação de produtos, sendo que também há um grande empenho, por parte de empresas italianas, em estabelecerem seus negócios no país. Isso exige que os profissionais envolvidos tenham conhecimento do vocabulário indispensável ao elaborar um contrato, por exemplo, ou até mesmo ao atender um cliente que não saiba se comunicar em português. Para atuar em questões que envolvem o nosso país e a Itália, é importantíssimo o conhecimento das leis italianas, o que torna possível compará-las às leis brasileiras. Para tanto, não basta somente ter uma tradução da lei; é necessário compreender o idioma estrangeiro e saber comunicar-se nele, pois a comunicação envolve, também, a cultura do país, e o conhecimento cultural facilita a compreensão e a solução dos problemas. Torna-se relevante, portanto, um estudo aprofundado 
e específico do idioma, que ajudará o jurista a solucionar, com mais desenvoltura, problemas de ordem profissional.

É relevante sublinhar que, do ponto de vista da sintaxe e da organização do texto, a linguagem jurídica, diferentemente das linguagens das matérias científicas (que se caracterizam por um uso muito restrito dos tempos verbais), recorre a um número muito mais amplo de tempos e modos e apresenta, normalmente, períodos muito longos e complexos, com subordinadas frequentemente implícitas, notável recurso do gerúndio e do particípio presente, frequente utilização da voz passiva e da forma impessoal. A linguagem jurídica, portanto, possui uma estrutura textual particularmente complexa, que pode ser dificilmente compreensível, até mesmo, para um falante nativo (SEMPLICI, 1996). Nesse contexto, é necessário que o jurista brasileiro consiga também alcançar o domínio do vocabulário jurídico italiano. Portanto, parece ser importante a existência de metodologias especiais e de materiais adequados para a aprendizagem específica em questão. Esse assunto será tratado ao fazermos a análise dos materiais, no segundo capítulo.

O processo de ensino pressupõe que se façam escolhas. Para fazê-las, é necessário realizar uma análise das necessidades de comunicação dos discentes. Tal análise é um dos requisitos fundamentais para a preparação de um curso de italiano para juristas. A expressão "análise das necessidades" refere-se, de modo geral, à coleta e à análise das informações necessárias para a tomada de decisões criteriosas relativas à escolha do tipo de atividades que serão utilizadas a fim de desenvolver as habilidades de leitura e compreensão de textos, além da comunicação oral e escrita. Essa análise oferece a possibilidade de refletir sobre o plano de ensino e a execução de um 
programa linguístico e é usada para estabelecer os objetivos, avaliar e efetuar os ajustes no planejamento, se necessários.

Partindo-se de tal análise, redefine-se o objetivo geral da aprendizagem e chega-se aos objetivos de ensino específicos para atender as necessidades peculiares de um determinado grupo de alunos. A partir dessa redefinição, inicia-se o trabalho com o desenvolvimento das habilidades e competências na língua estrangeira. Para realizar esse trabalho, fizemos, nos cursos que ministramos e que descrevemos nesta dissertação, a análise das necessidades discentes, como mostraremos adiante.

$\mathrm{Na}$ organização dos cursos, é importante destacar a diferença entre as línguas específicas e as línguas setoriais. Trataremos, no primeiro capítulo, das diferenças referentes à terminologia adotada pelos autores no Brasil e na Itália, explicando como cada um deles conceitua o estudo da língua com fins específicos e qual a distinção feita por cada teórico.

O ensino do italiano com fins específicos do qual tratamos propõe o desenvolvimento das quatro habilidades comunicativas: ler, ouvir (e entender o que se ouve), falar e escrever. Decidimos esclarecer isso para que não se confunda o tipo de curso que propomos com o de italiano instrumental, muito conhecido no meio acadêmico e que desenvolve, basicamente, a habilidade de leitura e compreensão de textos (MORDENTE, 2011); discorreremos a respeito dos cursos de italiano instrumental mais adiante. No presente trabalho, usaremos os termos "italiano com fins específicos" quando nos referirmos ao ensino com fins específicos em âmbito geral, e "italiano jurídico" para referirmonos ao ensino-aprendizagem do italiano com fins específicos envolvendo a linguagem usada no Direito. 
A nosso ver, as aulas de italiano jurídico podem ser ministradas para alunos que não tenham nenhum conhecimento dessa língua, e não somente para estudantes que tenham o nível intermediário do idioma. Acreditamos que podem ser desenvolvidas as quatro habilidades (escuta, leitura, fala e escrita) dentro do contexto jurídico do idioma. Trabalhando as quatro habilidades, o aluno passa a se comunicar tanto no âmbito geral quanto no jurídico.

Para tentarmos comprovar isso, no terceiro capítulo do presente trabalho, reportamos uma pesquisa que envolveu a organização de dois cursos de italiano jurídico, com metodologia e materiais específicos, através dos quais procuramos desenvolver as quatro habilidades linguísticas. Nesse sentido, parece-nos que não seja necessário que o aprendiz tenha conhecimento anterior da língua italiana, basta que tenha o conhecimento técnico no âmbito jurídico.

O nosso objetivo, no presente trabalho, consiste em avaliar o uso de materiais didáticos em dois momentos distintos. Primeiramente, partindo das análises preliminares de dois manuais para o ensino do italiano jurídico, identificamos (dentro do perfil do aluno indicado por tais livros) as dificuldades de produção oral e escrita dos discentes aos quais esses materiais são destinados. Para alcançar esse objetivo elaboramos alguns materiais didáticos para avaliar a produção dos alunos, (por meio de leitura, compreensão de textos e redações elaboradas pelos alunos) e, posteriormente, compará-las às produções realizadas com base nas atividades do manual didático. Propusemos uma avaliação em forma de apresentação de seminário e filmamos essa produção oral dos alunos. Essa apresentação foi realizada a partir de textos autênticos pesquisados por eles. 
Para desenvolver essa primeira análise, ministramos um curso para alunos com o nível intermediário do idioma italiano na Casa do Advogado da Ordem dos Advogados (OAB) de Jundiaí/SP, 33aㅗ Subseção. A escolha pela cidade de Jundiaí foi, em primeiro lugar, puramente logística, já que a autora reside na cidade, e em segundo lugar porque a cidade de Jundiaí hospeda mais de $75 \%$ de descendentes de origem italiana, sendo, portanto, uma cidade muito ligada à cultura e à língua italianas ${ }^{1}$. Essa pesquisa será vista, detalhadamente, na parte 3.1. Em segundo lugar, desenvolvemos uma pesquisa de campo direcionada ao ensino do italiano jurídico para alunos principiantes no idioma. Para coletar os dados da nossa pesquisa, preparamos e ministramos um curso para um público específico. Esse curso foi elaborado para os alunos da faculdade de Direito da Universidade de São Paulo, conhecida popularmente por faculdade de Direito do Largo São Francisco, e o nosso objetivo principal foi desenvolver as quatro habilidades em língua italiana, agregando-as à competência da leitura de textos específicos da área jurídica.

Os cursos foram realizados ao longo de dois semestres, nos quais tivemos a oportunidade de avaliar as produções orais e escritas dos estudantes, observando, em tais produções, o uso de termos jurídicos e o uso da língua italiana.

Ao final desse trabalho, analisamos os dados coletados a partir da nossa experiência empírica, fazendo considerações sobre o primeiro curso ministrado aos alunos de nível intermediário, de acordo com o perfil indicado pelos 
manuais utilizados, e também sobre a viabilidade da estrutura do segundo curso proposto, o de italiano jurídico para iniciantes. 


\section{1- O ESTUdO DO ITALIANO COM FINS ESPECÍfICOS. O ITALIANO JURÍDICO}

Dalla nascita alla morte, ogni giorno, viviamo in un oceano di parole?

Gian Luigi Beccaria

\section{1- Evolução histórica do italiano: os primeiros textos jurídicos}

Considerando que a nossa pesquisa diz respeito ao ensino do italiano jurídico, acreditamos ser de grande importância salientar que o uso do italiano vulgar apareceu, pela primeira vez, em textos jurídicos.

Podemos considerar que as diferenças entre o latim (empregado como língua culta pelos juristas e pelos eclesiásticos) e a língua falada pelo povo, aprofundaram-se, em toda a Europa, a partir da queda do Império Romano do Ocidente. Nasceram, assim, os idiomas vulgares, precursores das línguas nacionais:

O uso do vulgar faz progressos na legislação e no procedimento de diversos Estados italianos: a Toscana está na vanguarda, enquanto o mais relutante em abandonar o latim é - Estado da Igreja. O cardeal De Luca, na sua interessante dissertação Defesa da língua italiana (Roma 1675), propunha, com vivo e sólido sentimento, o uso do italiano, vinculando-o à sua enciclopédia legal, Doutor vulgar, do mesmo autor (Roma 1673). (MIGLIORINI, 1967, p. 410, tradução nossa $\left.{ }^{3}\right)^{4}$.

\footnotetext{
2 (BECCARIA, 2002, p. 09)

${ }^{3}$ Nota: todas as traduções feitas por nós, no presente trabalho, terão o texto original em nota de rodapé.

${ }^{4}$ No original: L'uso del volgare fa progressi nella legislazione e nella procedura dei diversi Stati italiani: la Toscana è all'avanguardia, mentre il più restio ad abbandonare il latino è lo Stato della Chiesa. II card. De Luca, nella sua interessante dissertazione Difesa della lingua italiana (Roma 1675), propugna, con vivo senso di concretezza, l'uso dell'italiano, in connessione con quella specie di enciclopedia legale che è il Dottor volgare dello stesso autore (Roma 1673).
} 
Os vários vulgares se transformaram no que chamamos, hoje, de italiano padrão. Refletindo a esse respeito, concluímos que o "italiano vulgar" difundiuse, pois, na verdade, era falado pela maior parte da população, já que poucos tinham acesso à cultura das elites, na qual era usado o latim.

É interessante salientar que, até pouco tempo atrás, os primeiros textos reconhecidos como documentos escritos em vulgar italiano eram os "placiti cassinesi". Trata-se de documentos jurídicos que diziam respeito a um litígio sobre a disputa de algumas terras. As partes do litígio eram o mosteiro de Montecassino e um agricultor chamado Rodelgrimo d'Aquino. Nesses documentos, aparece a transcrição de três testemunhos a favor do mosteiro dos Beneditinos, diante do juiz Arechisi. As testemunhas indicavam com um dedo o local da divisa que tinha sido ocupada ilicitamente pelo camponês, depois da destruição da abadia em 885 pelos sarracenos. Os documentos jurídicos são agrupados em quatro pergaminhos:

Os documentos em que, pela primeira vez, o vulgar aparece em plena luz, conscientemente contraposto ao latim, são os quatro "placiti cassinesi". Trata-se de um conjunto de quatro pergaminhos de argumento análogo (quatro plácidos ou, mais exatamente, três plácidos e um "memorando" sobre a posse de certas terras, nos quais a base para a decisão é fornecida por testemunhas juramentadas), pertencentes ao mesmo tempo (o breve período de 960 a 963) e aos mesmos lugares. (MIGLIORINI, 1967, p. 91) ${ }^{5}$.

\footnotetext{
5 No original: I documenti in cui per la prima volta il volgare appare in piena luce, coscientemente contrapposto al latino, sono i quatro placiti cassinesi. Si tratta di un gruppetto compatto di quatro pergamene di analogo argomento (quattro placiti o più esattamente tre placiti e un "memoratorio" sull'appartenenza di certe terre, nei quali la base per la decisione è fornita da testimonianze giurate), appartenenti allo stesso tempo (il breve período dal 960 al 963) e agli stessi luoghi.
} 
A oitiva das testemunhas foi colhida em língua vulgar, e esses textos forneceram a base para a fundamentação da decisão jurídica. A fórmula ${ }^{6}$ comunicada pelo juiz foi reproduzida e apresentada da seguinte maneira:

(Capua, março de 960):

Sei que aquelas terras, naquelas fronteiras em que estão incluídas, trinta anos as possuíram os Beneditinos.

(Sessa, março de 963):

Sei que aquelas terras, naquelas fronteiras que lhe mostrei, e em que estão incluídas, pertenceram a Pergoaldo, que as possuiu durante trinta anos.

(Teano, julho de 963):

Aquelas terras, naquelas fronteiras que lhes mostrei, são de santa Maria, que trinta anos as possuiu.

(Teano, outubro 963):

Sei que aquelas terras, naquelas fronteiras que lhe mostrei, trinta anos as possuiu santa Maria. (MIGLIORINI, 1967, p. 92) ${ }^{7}$.

Segundo Migliorini, esses documentos são os primeiros que apresentam uma linguagem cartorária, e refletem a língua regional, da Campânia, falada habitualmente por juristas e eclesiásticos na segunda metade do século $X$ :

Mas aquela linguagem regional continha também elementos inter-regionais e de duas espécies diferentes: latinismos e italianismos. Ou melhor, e mais simplesmente: elementos em latim e em italiano. O mais certeiro de tais elementos é sao, do qual provém so (sei). (MIGLIORINI, 1967, p. 92). ${ }^{8}$

\footnotetext{
${ }^{6}$ Expressão linguística cujo uso é frequentemente exigido pelo Direito para que possua certos efeitos jurídicos, como a validade de uma norma ou de um contrato. (AMARAL, 2006)

${ }^{7}$ No original: (Capua, marzo 960): Sao ko kelle terre, per kelle fini que ki contene, trenta anni le possette parte sancti Benedicti. (Sessa, marzo 963): Sao cco kelle terre, per kelle fini que tebe monstrai, Pergoaldi foro, que ki contene, et trenta anni le possette. (Teano, luglio 963): Kella terra, per kelle fini que bobe mostrai, sancte Marie è, et trenta anni la posset parte sancte Marie. (Teano, ottobre 963): Sao cco kelle terre, per kelle fini que tebe mostrai, trenta anni le possette parte sancte Marie.

${ }^{8}$ No original: Ma quel linguaggio regionale conteneva anche elementi interregionali e di due specie diverse: latinismi e italianismi. O meglio e più semplicemente: elementi latini e italiani. II più sicuro di tali elementi è sao, onde so.
} 
Ao colher os testemunhos em língua italiana vulgar, o que, até então, era feito em latim, o juiz abriu um precedente, ou seja, posteriormente, outros documentos começaram a ser escritos na língua do povo. Esse fato contribuiu para a difusão do uso do italiano, sobrepondo-o ao uso do latim. Nesse contexto, ao servir-se da língua do povo para documentar fatos que eram relatados pelo próprio povo, do ponto de vista jurídico, o juiz estava somente agindo de acordo com a realidade das partes e cumprindo o seu papel social diante da solução do litígio.

No entanto, segundo estudos mais recentes, os "placiti cassinesi" perderam o seu lugar de primeiros documentos escritos em língua italiana vulgar $^{9}$. Todavia:

...Resta aos "placiti cassinesi" o primeiro lugar entre os documentos de interesse jurídico: além de serem os mais antigos com data certa e que mostram abertamente uma clara distinção entre vulgar e latim (FIORELLI, 1994, p. 555) ${ }^{10}$.

Posteriormente, um dos fatos históricos que contribuiu grandemente para a difusão da língua italiana foi a elaboração dos códigos, principalmente o Civil e o Penal. Em 1865, houve a promulgação do Código Civil e, em 1889, a do Código Penal. Esses códigos foram influenciados pelo surgimento do Código de Napoleão, em 1804, que marcou a Era das Codificações ${ }^{11}$. O

\footnotetext{
9 Fiorelli aponta "l'indovinello di Verona", "l'iscrizione della catacomba romana di Commodilla" e "il glossario di Monza" como os documentos mais antigos em língua italiana vulgar. (FIORELLI, 1994, p. 555)

10 No original: Resta ai placiti cassinesi il primo posto tra i documenti d'interesse giuridico: oltre all'essere i più antichi che abbiano data certa e che, per giunta, mostrino apertamente una consapevole distinzione tra volgare e latino.

${ }^{11}$ A codificação é um movimento jurídico aparecido no Ocidente no século XIX, em função do qual os direitos ocidentais, quanto à forma, se dividem em: direito continental, ou direito codificado, que compreende o grupo francês, tendo por ponto de partida o Código de Napoleão (Code Civil des Français), e o grupo alemão; e sistema do Common Law ou do grupo AngloAmericano. Disponível em: http://jus.com.br/artigos/3549/a-codificacao-dodireito\#ixzz2c4NYMEQ7. Acesso em 15 de agosto 2012.
} 
Código de Napoleão foi o mais influente dos códigos legais, apesar de não ter sido o primeiro.

Na Itália e em outros países da Europa, a adoção do Código de Napoleão influenciou a formação das bases dos sistemas legais modernos. Dessa forma, a linguagem usada pelo aparato administrativo entrou na vida quotidiana dos italianos, refletindo-se, sobretudo, na língua falada. Isso repercutiu também na elaboração de uma língua jurídica italiana comum em toda a Itália:

Sob o governo napoleônico instaurou-se um aparato administrativo e burocrático moderno e em 1806 no Reino itálico foi emanado o Código civil bilíngue, italiano e francês, um passo importante para a difusão de uma terminologia jurídica unitária. (ZOLLI, 1974)..$^{12}$

De fato, após a unificação da Itália (1861), tornou-se necessário chegar a um consenso principalmente no que diz respeito às normas linguísticas que atingiriam a todos os italianos. A escola, finalmente obrigatória para todos, contribuiu grandemente para a alfabetização de massa e para a difusão do italiano como língua nacional.

Depois da queda do fascismo e do fim da Segunda Guerra Mundial, é evidente a preocupação com a língua no texto da Constituição da República Italiana, que foi promulgada em dezembro de 1947 e entrou em vigor no dia 01 de janeiro de 1948. No artigo terceiro da Constituição, podemos ler: Todos os cidadãos tem a mesma dignidade social e são iguais perante a lei, sem

\footnotetext{
12 No original: Sotto il governo napoleonico si instaurò un apparato amministrativo e burocratico moderno e nel 1806 nel Regno italico fu emanato il Codice civile in testo bilingue, italiano e francese, un passo importante per la diffusione di una terminologia giuridica unitaria (ZOLLI, 1974). Disponível em: http://www.treccani.it/enciclopedia/lingua-dell-ottocento (Enciclopediadell'Italiano)/. Acesso em 15 de agosto de 2012.
} 
distinção de sexo, de raça, de língua, de religião, de opiniões políticas, de condições pessoais e sociais ${ }^{13}$ (grifo nosso).

Portanto, podemos dizer que as condições socioculturais, econômicas, jurídicas e científicas, contribuíram para a evolução linguística na Itália. Nos últimos anos, de acordo com Beccaria, a língua italiana está atravessando uma fase típica de todas as línguas modernas:

Agora, estamos atravessando outra fase, típica de todas as línguas modernas, devido à maior divisão do trabalho, que torna os falantes reciprocamente sempre mais distantes, incide sobre a própria compreensão dos discursos desenvolvidos pela mídia, pela escola, pelos centros de atividade política. O italiano setoriza-se, nascem léxicos particulares das várias técnicas ou atividades profissionais, estabilizam-se códigos corporativos, linguagens com circuito fechado. (BECCARIA, 2002, p. 172). ${ }^{14}$

Para Beccaria, não se trata mais somente de variações geográficas ou de variedades sociais ou de registro, mas de variedades funcionais para uma comunicação que se desenvolve sobre assuntos específicos, em âmbitos particulares de setores de atividades e profissões.

Diante disso, podemos reafirmar que o italiano jurídico pertence ao ramo das línguas que se especializaram, o que o tornou uma das muitas línguas com fins específicos. Mas, como os autores italianos definem o ensino das línguas com fins específicos? E como é ensinado o italiano jurídico hoje, no Brasil? No decorrer deste trabalho, procuraremos responder essas e outras questões.

\footnotetext{
${ }^{13}$ No original: Tutti i cittadini hanno pari dignità sociale e sono eguali davanti la legge, senza distinzione di sesso, di razza, di lingua, di religione, di opinioni politiche, di condizioni personali e social.

${ }^{14}$ No original: Ora stiamo attraversando un'altra fase, tipica di tutte le lingue moderne, dovuta alla sempre più accentuata divisione del lavoro, che rende i parlanti reciprocamente sempre più estranei, incide a volte sulla stessa comprensibilità dei discorsi svolti dai mass media, dalla scuola, dai centri di attività politica. L'italiano si settorializza, nascono lessici privati delle varie tecniche 0 attività professionali, si stabilizzano dei codici corporativi, dei linguaggi a circuito chiuso.
} 


\section{2- Definições do conceito de línguas com fins específicos por autores italianos}

Segundo Sobrero e Miglietta (2006), as línguas com fins específicos são divididas em dois grupos: lingue specialistiche e lingue settoriali (respectivamente: línguas específicas e línguas setoriais):

As línguas específicas são aquelas que preveem um alto grau de especialização (física, medicina, matemática, linguística, informática); as línguas setoriais são aquelas relativas a setores ou âmbitos de trabalho não especializados: a língua dos jornais, da televisão, da publicidade etc. Os dois grupos constituem o conjunto das línguas especiais. (SOBRERO, MIGLIETTA, 2006, p. 137) ${ }^{15}$.

Esses autores consideram que a diferença entre as línguas específicas e as línguas setoriais está, fundamentalmente, no vocabulário. Para eles, as línguas específicas possuem um léxico próprio, isto é, um conjunto de termos técnicos relativos à matéria, organizado e ordenado conforme normas convencionais; enquanto que as línguas setoriais não o têm, mas partem da língua comum ou de outras línguas especializadas para compor seu léxico.

Os dois teóricos consideram, ainda, que essa diferença não é formal, mas ligada aos objetivos próprios da comunicação:

Enquanto os textos específicos têm uma circulação limitada, os setoriais têm uma difusão mais vasta e um maior número de usuários, além de utilizarem um léxico menos específico, mais próximo da língua comum exatamente para corresponder à exigência de compreensão de um público mais amplo e diferenciado. (SOBRERO, MIGLIETTA, 2006, p. 137). ${ }^{16}$

\footnotetext{
15 No original: [...] lingue specialistiche le varietà che prevedono un alto grado di specializzazione (fisica, medicina, matematica, linguistica, informatica) e lingue settoriali quelle che riguardano settori o ambiti di lavoro non specialistici: lingua dei giornali, della televisione, della pubblicità ecc. I due sottoinsiemi 'lingue specialistiche 'e 'lingue settoriali' costituiscono l'insieme 'lingue speciali'.

${ }^{16}$ No original: [...] mentre i testi specialistici hanno una circolazione limitata (presso gli esperti , i tecnici, gli studiosi), quelli settoriali hanno una diffusione più vasta e un maggior numero di fruitori, e usano un lessico meno specialistico ma più vicino alla lingua comune proprio per rispondere all'esigenza di farsi capire da un pubblico più ampio e differenziato.
} 
Já Elena Ballarin, em seu texto "Didattica delle microlingue", atesta que há um problema de definição no que diz respeito ao uso da língua e, para solucionar o problema, opta pelo uso dos termos "macrolíngua" e "microlíngua". Define a macrolinguística como o estudo das línguas naturais, incluindo a semântica linguística, a pragmática e a sociolinguística, enquanto a microlíngua seria um sinônimo da expressão "língua setorial" (BALLARIN, 2011).

Para entendermos melhor os termos usados pela autora, efetuamos uma pesquisa, no dicionário on line da enciclopédia Treccani, no qual não encontramos o termo "macrolíngua", mas encontramos a definição de "macrolinguística", que consiste em:

Termo usado para designar os estudos de linguística quantitativa (nos quais se examinam fenômenos linguísticos de massa: por exemplo, a relação entre todas as palavras de igual frequência media e a sua estrutura fonética), opondo-se aos estudos de microlinguística, isto é, de linguística descritiva e histórica, em que se consideram as unidades ou pequenos grupos de unidade ${ }^{17}$.

Também no dicionário Treccani ${ }^{18}$, encontramos a definição de microlíngua:

Termo usado por alguns linguistas como sinônimo de linguagem setorial, para indicar as linguagens técnicas e especializadas que, usadas em determinados setores da ciência, da técnica, das atividades de produção, constituem-se como variedades no seio da língua comum, com características típicas próprias tanto no plano lexical (constituição de uma terminologia própria, prevalência da denotação sobre a conotação e da monossemia sobre a polissemia etc.) como no plano morfossintático (preferência por algumas estruturas sintáticas, tendência à frase nominal etc. $)^{19}$.

\footnotetext{
17 No original: Macrolinguistica. s. f. [comp. di macro-e linguistica]. - Termine con cui sono talora designati gli studi di linguistica quantitativa (nei quali si prendono in esame fenomeni linguistici di massa: per es., il rapporto tra tutte le parole d'ugual frequenza media e la loro struttura fonematica), in opposizione agli studî di microlinguistica, cioè di linguistica descrittiva e storica, in cui si considerano singole unità o piccoli gruppi di unità. Disponível em: http://www.treccani.it/vocabolario/macrolinguistica/. Acesso em janeiro 2011.

18 Nota: A enciclopédia Treccani está disponível em http://www.treccani.it/. O dicionário Treccani está disponível em: http://www.treccani.it/vocabolario/. Acesso em janeiro de 2011.

${ }^{19}$ No original: Microlìngua s. f. [comp. di micro-e lingua]. - Termine usato da alcuni linguisti come sinon. di linguaggio settoriale, per indicare cioè quei linguaggi tecnici o specialistici che, in
} 
De acordo com o dicionário on line Treccani, alguns linguistas italianos dividem o estudo da língua em setores. Consideram a macrolinguística como o âmbito geral do estudo da língua comum, e as diversas microlínguas como divisões especializadas que estão inseridas no conjunto da macrolinguística.

A linguagem jurídica e a filosófica (e também a da crítica literária e a artística), com certeza incluem-se no ramo das microlínguas. Por conseguinte, é possível distinguir as microlínguas da língua comum, analisando aspectos fonológicos, morfossintáticos, lexicais e textuais. Todos os falantes adultos sabem fazer essa distinção intuitivamente; todavia, somente uma análise mais aprofundada do contexto pode realmente esclarecer a distinção entre as várias realizações linguísticas que se destacam da língua "comum", colocando-as no nível de microlíngua, de língua literária ou das várias formas de gíria.

A seguir, vejamos o que outros autores italianos dizem acerca das línguas especiais e dos termos usados para designá-las:

Gaetano Berruto usa o termo sottocodici (subcódigos) afirmando que são variedades diafásicas caracterizadas por um léxico especial. Para ele, a função dos "sottocodici" é disponibilizar uma simbologia que possibilita uma comunicação de forma unívoca, precisa e econômica e, portanto, mais eficaz e funcional no que diz respeito a temas específicos (BERRUTO, 1997).

Para Berruto, o vocabulário técnico dos sottocodici seria, na verdade, uma nomenclatura, ou seja, uma terminologia cuja estrutura tem como referência campos extralinguísticos.

uso in determinati settori della scienza, della tecnica, delle attività produttive, costituiscono altrettante varietà in seno alla lingua comune, con caratteri tipici propri sia sul piano lessicale (costituzione di una propria terminologia, prevalenza della denotazione sulla connotazione e della monosemia sulla polisemia, ecc.) sia sul piano morfosintattico (preferenza per alcune strutture sintattiche, tendenza alla frase nominale, ecc.). Disponível em: http://www.treccani.it/vocabolario/microlingua/. Acesso em janeiro de 2011. 
O léxico especial dos subcódigos se constitui de acordo com três modalidades: ou associando um significante novo e específico a um significado novo e específico [...], ou associando um significante já existente na língua a um significado novo, [...] ou, - mais raramente - associando um significante novo a um significado já existente [...]. (BERRUTO, 1997$, p. 154$)^{20}$

\section{Giacomo Devoto usa as expressões lingue speciali e specialistiche}

(línguas especiais e específicas) e ressalta que a língua científica italiana foi personificada por Galilei (1564-1642): segundo Devoto (1974), Galilei a influenciou decisivamente ao transformar palavras da língua "comum" em palavras técnicas.

Paolo Balboni (2009) usa a expressão microlingue (microlínguas), definindo o termo como:

[...] variedades da língua que são usadas entre os especialistas de um setor, tanto para aumentar a clareza e reduzir a ambiguidade, como para possibilitar que, por meio de um estilo microlinguístico, os membros de uma "corporação" se reconheçam entre si como profissionais, excluindo, portanto, os leigos (BALBONI, 2009, p. 33) ${ }^{21}$.

Quanto à didática das microlínguas, ele afirma que:

Um currículo de microlíngua, mesmo privilegiando o aspecto instrutivo, pode incluir também metas educativas: culturização no universo da pesquisa científica ou da profissão; socialização na "comunidade do discurso" que reconhece, entre outras coisas, o uso da microlíngua; autopromoção como técnico, estudioso, profissional. (BALBONI, 2010, p. 190) ${ }^{22}$.

\footnotetext{
${ }^{20}$ No original: II lessico speciale dei sottocodici si costituisce secondo tre modalità: o associando un significante nuovo e specifico a un significato nuovo e specifico [...], o associando un significante già esistente nella lingua a un significato nuovo, [...] $0,-$ più raramente associando un significante nuovo a un significato già existente [...].

${ }^{21}$ No original: [...] varietà di língua che si usano tra specialisti di un settore sia per aumentare la chiarezza e ridurre l'ambiguità, sia perché attraverso un particolare stile microlinguistico i membri di una "corporazione" si riconoscono tra loro come professionisti, escludendo dunque i dilettanti. P.33.

${ }^{22}$ No original: Un curricolo di microlingua, pur privilegiando l'aspetto istruttivo, può includere anche le mete educative: culturizzazione nell'universo della ricerca scientifica o della professione; socializzazione nella "comunità di discorso" che si riconosce, tra l'altro, per l'uso della microlingua; autopromozione come tecnico, studioso, professionista.
} 
Já Francesco Sabatini adota os termos linguaggi speciali ou settoriali (linguagens especiais ou setoriais) e esclarece que a existência de línguas especiais não é um fenômeno novo, porque em todos os países e em todos os grupos de profissionais quem desenvolvia o mesmo tipo de trabalho tinha um modo próprio de se comunicar no contexto do ambiente profissional. Diz ainda que:

Chamamos "linguagem especial" aquele tipo particular de língua que usam os especialistas de um certo ramo de atividade, de estudos, etc., quando falam ou escrevem sobre o próprio trabalho. Essas linguagens são também chamadas de "setoriais" porque dizem respeito, justamente, a cada um dos setores da atividade. (SABATINI, 1998, p. 544) ${ }^{23}$

Gian Luigi Beccaria usa o termo linguaggio settoriale (linguagem setorial) e diz que, "na realidade, as linguagens setoriais não passam de "províncias" variadas de um italiano especializado, que, se por um lado, fragmentam, por outro lado, tornam fluente e variado o mosaico da língua" (BECCARIA, 2002, p. $172)^{24}$.

Ainda segundo Beccaria, na linguagem setorial, deve ser valorizada a função designativa da palavra. Acrescenta que, no âmbito específico da linguagem, cada palavra quer dizer uma única coisa para ser usada com um objetivo bem preciso (BECCARIA, 2002).

Maurizio Gotti adota a expressão linguaggi specialistici (linguagens específicas), desenvolvendo pesquisas nessa área na Università degli Studi di

\footnotetext{
${ }^{23}$ No original: Chiamiamo "linguaggio speciale" quel tipo particolare di lingua che usano gli specialisti di un qualche ramo di attività, di studi, ecc., quando parlano o scrivono del proprio lavoro. Questi linguaggi vengono anche chiamati "settoriali" perché riguardano, appunto, i singoli settori di attività.

${ }^{24}$ In realtà i linguaggi settoriali non costituiscono che "province" varie di un italiano specializzato che tornano sì a frantumare per un verso, ma per altro a rendere fluido e variegato il mosaico della lingua.
} 
Bergamo, no CERLIS (Centro di Ricerca sui Linguaggi Specialistici) do qual é diretor. Interessante observar que:

O Centro de pesquisa sobre Linguagem Especializada (CERLIS) foi instituído em 1999 com o objetivo de desenvolver iniciativas comuns de pesquisas no âmbito das linguagens especializadas, seja do ponto de vista sincrônico que diacrônico. Baseados no Regulamento Institucional, para alcançar os seus objetivos, o Centro prevê a: promover, sustentar e coordenar pesquisas, favorecer a coleta e a troca de documentação, informações e materiais aptos à pesquisa, também no quadro de colaborações com outros organismos e entes de pesquisa nacionais e internacionais, públicos e privados; estimular iniciativas de divulgação por meio de conferências, congressos, cursos, etc., publicando os resultados científicos obtidos; promover a elaboração de materiais para a didática das linguagens especializadas. ${ }^{25}$

Por fim, Coveri et al. (1998, p. 172) ressaltam que um grande problema a ser enfrentado no tocante à língua com fins específicos diz respeito à terminologia adotada por diferentes autores italianos. Para ilustrar o problema, Coveri apresenta, de maneira sintética, os termos empregados por alguns desses autores:

Devoto, Cortelazzo e Berruto usam linguaggi speciali e lingue speciali; Beccaria e Dardano preferem linguaggi settoriali; Wandruszka opta por tecnoletti; Balboni prefere microlingue; Berruto, Dardano, Berretta e Sabatini usam, também, o termo sottocodici; De Mauro e seus seguidores usam lingue per scopi speciali; Gensini optou por sottocodici specializzati; Gotti usa linguaggi specialistici; Sobrero adotou lingue speciali/ sottocodici ${ }^{26}$.

\footnotetext{
${ }^{25}$ No original: II Centro di Ricerca sui Linguaggi Specialistici (CERLIS) è stato istituito nel 1999 al fine di sviluppare iniziative comuni di ricerca nell'ambito dei linguaggi specialistici sia in chiave sincronica che diacronica. Sulla base del Regolamento istitutivo, per conseguire i suoi scopi il Centro provvede a: promuovere, sostenere e coordinare ricerche; favorire la raccolta e lo scambio di documentazione, informazioni e materiali atti alla ricerca, anche nel quadro di collaborazioni con altri organismi ed enti di ricerca nazionali e internazionali, pubblici e privati; stimolare iniziative di divulgazione tramite conferenze, convegni, corsi, ecc., pubblicando i risultati scientifici ottenuti; promuovere l'elaborazione di materiali per la didattica dei linguaggi specialistici. Disponível em: http://dinamico.unibg.it/cerlis/page.aspx?p=4. Acesso em $10 \mathrm{de}$ janeiro de 2013.

26 No original: Troviamo: linguaggi speciali e lingue speciali in Devoto (1939 a, b), Cortelazzo (1988 a e 1990 a) e Berruto (1987); linguaggi settoriali risalente a Beccaria (1973, 1986) ma anche in Dardano (1987); tecnoletti per Wandruszka (1974); microlingue per Balboni (1982); sottocodici per Berruto (1974 e oltre), Dardano (1973), Berretta (1988), Sabatini (1990 b); lingue per scopi speciali per la scuola di De Mauro; sottocodici specializzati in Gensini (1986); linguaggi specialistici in Gotti (1991); lingue speciali/ sottocodici in Sobrero (1993 b).
} 
Em síntese, podemos dizer que cada um dos autores adotou o seu próprio termo; no entanto, visto que, no Brasil, a denominação mais conhecida é língua com fins específicos, optamos por adotá-la no presente trabalho. Ademais, como nossa pesquisa refere-se à língua específica do Direito, usaremos, também, a expressão italiano jurídico.

\section{3- As línguas com fins específicos na Itália: algumas pesquisas}

Com o objetivo de encontrar trabalhos (teses, dissertações, monografias, e artigos) que tratassem da língua italiana com fins específicos, fizemos uma pesquisa em alguns sites de universidades italianas. Ao realizá-la, constatamos, no entanto, que a maioria desses trabalhos não estava integralmente disponível. Por isso, infelizmente, não pudemos acessá-los. Assim sendo, analisaremos apenas três artigos (disponíveis na íntegra) na presente dissertação. A nosso ver, esses três textos são importantes justamente por consistirem em trabalhos realizados na área da língua italiana com fins específicos.

No primeiro trabalho analisado, realizado por alunos do Departamento de Ciências da Comunicação da Universidade de Salerno: "Strutture lessicali delle informazioni comunitarie all'interno di domini specialistici" (ELIA et al, 2010 $)^{27}$, os autores explicam que as informações, dentro da comunidade Europeia, são veiculadas por meio de termos técnicos específicos. Esses termos, são agrupados em glossários pelas instituições que deles se utilizam, facilitando, assim, a comunicação. O estudo diz respeito à descrição das

27 ELIA, A. et al. Disponível em: http://www.ledonline.it/ledonline/JADT-2010/allegati/JADT2010-1227-1236_159-Elia.pdf. Acesso em janeiro 2012. 
estruturas que compõem as unidades lexicais dos dicionários eletrônicos de domínio público desenvolvidos por meio de corpora de textos tipificados de acordo com a informação comunitária, a fim de obter informações sobre as distribuições de frequências úteis para indagar os processos múltiplos de rematização.

Desde 1988, o Departamento de Ciências da Comunicação da Universidade de Salerno (Itália) desenvolve um sistema de dicionários eletrônicos chamado DELA, com palavras simples e compostas. No artigo já referido, os autores explicam que desenvolvem um estudo para descrever as unidades lexicais presentes nos textos e glossários institucionais, além de fazer a catalogação morfológica e gramatical para a construção de dicionários eletrônicos de domínios especializados para informações comunitárias. Abordam as informações difundidas pelas instituições da União Europeia por meio de vários gêneros de textos em diferentes processos de comunicação. Os organismos comunitários são fonte de direito e de políticas de desenvolvimento socioeconômico, por isso são múltiplos os domínios especializados das informações comunitárias.

Esse artigo é interessante, pois demonstra a preocupação dos estudiosos em veicular o léxico especializado, disponibilizando dicionários em formato eletrônico para facilitar a pesquisa e a consequente troca de informações.

O segundo artigo que citamos foi escrito por Rosario Coluccia (2001), "Le lingue della scienza oggi e ieri" para participar de um congresso em Lecce sobre o uso da linguagem na ciência. O artigo trata da evolução histórica da língua na ciência, mencionando, inclusive, a questão terminológica, pois, na 
bibliografia existente sobre o assunto, não se encontra uma uniformidade quanto à terminologia. Conforme já mencionamos no capítulo anterior, devido ao fato de não haver um consenso em relação à uniformidade terminológica (COLLUCIA, 2001), pode haver, até mesmo, alguma divergência no que diz respeito ao conteúdo. Para exemplificar isso, trazemos, aqui, alguns termos:

- Sottocodici (subcódigos): diz respeito à língua usada no funcionalismo público;

- Linguaggi settoriali (linguagens setoriais): línguas que tratam de interesses de setores específicos dos usuários;

- Lingue speciali (línguas especiais): compreendem, normalmente, as linguagens técnicas e científicas;

- Tecnoletto (tecnicismo): também usado para setores técnicos;

- Microlíngua (microlíngua): língua usada num grupo específico de profissionais, por exemplo, na informática.

No terceiro artigo, "La traduzione nell'insegnamento della lingua e nello studio dei linguaggi specialistici"28, Maria Vittoria Calvi, (2003) propôs alguns questionamentos a respeito da tradução pedagógica. Segundo ela, a tradução pode se constituir em um útil exercício didático no ensino de línguas estrangeiras, além de, representar, também, um objetivo específico de aprendizagem, em vários percursos de formação. A autora ressalta que, além das quatro habilidades primárias a serem trabalhadas em um curso de língua estrangeira, é necessário desenvolver, também, a habilidade da tradução, de acordo com cada nível de estudo do idioma.

28 Trabalho apresentado na Giornata di studio Milano 28 febbraio 2003. Disponível em http://www.ledonline.it/ledonline/index.html?/ledonline/tradurrespagnolo.html. Acesso em 28 de novembro de 2013. 
Ademais, Calvi considera oportuno definir critérios de avaliação dos exercícios de tradução, pois traduzir textos específicos requer instrumentos linguísticos adequados, e não somente conhecimentos terminológicos, pois, do ponto de vista didático, em primeiro lugar, o estudante deve reconhecer as características de cada gênero textual específico.

Ao analisarmos os três artigos mencionados, notamos que há certa preocupação dos pesquisadores com a questão da metodologia adotada para o ensino do italiano com fins específicos, não somente do ponto de vista didático, mas também terminológico.

Esses são somente alguns poucos exemplos de pesquisas que envolvem não apenas os pesquisadores italianos, mas também outros pesquisadores da Comunidade Europeia. E no Brasil? São realizadas pesquisas no âmbito do ensino do italiano com fins específicos?

\section{4- $O$ estudo de línguas com fins específicos no Brasil}

Devido à influência italiana na cultura brasileira e ao grande número de descendentes de italianos no Brasil, principalmente no estado de São Paulo, há certa tradição no estudo do idioma em nosso país. Porém, diferentemente do que ocorre na Itália, não há, no Brasil, muitos teóricos que se dedicaram às pesquisas sobre os diversos usos da linguagem direcionada para fins específicos e setoriais em italiano.

Embora não haja, em nosso país, muitas pesquisas desse tipo na área de italiano, encontram-se diversos estudos voltados para a linguagem com fins específicos nas áreas de francês, inglês, espanhol, português, entre outros. No 
presente capítulo, mencionaremos alguns desses estudos, sem, no entanto, ter a pretensão de aprofundarmo-nos no assunto.

No que diz respeito ao estudo de uma língua com fins específicos, verificamos que, há algumas décadas, o idioma estrangeiro mais procurado, sobretudo na Universidade de São Paulo, foi o francês. Na década de 1970, a FFLCH ${ }^{29}$ começou a oferecer o curso de "francês instrumental", o qual não trabalhava somente a leitura e a compreensão de textos como os cursos que são oferecidos ainda hoje, mas sim as quatro habilidades do idioma. A necessidade dos universitários e do público em geral em entender a língua francesa com urgência levou-os a procurar o curso de francês instrumental. No entanto, como esses alunos tinham o propósito de participar de outros cursos, geralmente ligados ao âmbito profissional, (cursos ministrados em francês) e também precisavam fazer leitura de textos que seriam utilizados em tais cursos, o curso de francês instrumental tinha o objetivo de atender a demanda desse público.

\begin{abstract}
O "francês instrumental", ou se quiserem, o "francês funcional", tem por objetivo oferecer um aprendizado de língua francesa que permita utilizar com a máxima eficácia toda e qualquer documentação escrita, oral, audiovisual em língua francesa numa especialidade qualquer à exclusão das de professor e tradutor-intérprete de francês - e abrir novos horizontes nos vários caminhos do saber. [...] Não se limita a noção de francês "técnico e científico" nem a de um aprendizado do francês tendo por único objetivo dar aos estudantes acesso aos textos escritos. (LARANJEIRA, LAUNAY et al, 1977, p. 25).
\end{abstract}

Em um Congresso da AUPELF $^{30}$ realizado na USP, em 1973, Vitor Ramos $^{31}$ lançou o grupo de trabalho consagrado precisamente à contribuição

\footnotetext{
${ }^{29}$ Faculdade de Filosofia, Letras, e Ciências Humanas da Universidade de São Paulo.

30 Association des universités partiellement ou entièrement de langue française (Associação das universidades parcialmente ou inteiramente de língua francesa).

${ }^{31}$ Prof. Vítor de Almeida Ramos, professor de Literatura Francesa da USP, integrante do grupo de estudos.
} 
da língua francesa ao desenvolvimento da América Latina, chegando a afirmar que:

Num mundo onde infelizmente chegamos a um ponto em que o divórcio entre as técnicas e as ciências humanas é cada vez mais visível, nunca será demais louvar o esforço da AUPELF no sentido de retardar este divórcio ou, e é aí que eu falo de milagre, de procurar um meio de reunir os dois ramos separados. (CANDIDO, 1977, p. 17).

O professor Antônio Candido, um dos principais organizadores do congresso, discorreu a esse respeito no livro que publicou em 1977, cujo título era O Francês Instrumental: A experiência da Universidade de São Paulo. Essa obra teve grande impacto no ensino de idiomas com fins específicos. A partir daquele momento, a língua passou a ser considerada como instrumento de acesso à bibliografia especializada para a qual não havia tradução em língua portuguesa. Diante dessa necessidade, começaram a surgir cursos de francês instrumental voltados para um público de jovens matemáticos, físicos, biólogos, geólogos etc. Esses cursos foram desenvolvidos pelo Centro de Estudos Franceses da Universidade de São Paulo em todas as Faculdades Científicas da USP.

Por outro lado, encontramos, também, registros de trabalhos acerca de línguas específicas realizados, em 1977, na Pontifícia Universidade Católica de São Paulo (PUC-SP), no âmbito do Programa de Estudos de Pós-graduados em Linguística Aplicada e Ensino de Línguas (LAEL).

Em meados de 1980, essa metodologia começava então a se expandir em diversos países da América Latina graças ao Professor Gerard Alvarez: o Francês Instrumental estava se desenvolvendo como o ensino do francês enquanto língua estrangeira destinada a públicos adultos especializados (AVOLIO, 2009, p. 57).

No que diz respeito ao ensino do inglês com fins específicos, ou seja, "English for Specific Purposes" (ESP), podemos dizer que o idioma ficou, 
historicamente, mais conhecido do que o francês na área de ensinoaprendizagem de línguas estrangeiras. Em um primeiro momento, o ensino de idiomas, em geral, era baseado, unicamente, no método de gramática e tradução; posteriormente, a partir da Segunda Guerra Mundial, e tendo como finalidade ensinar línguas europeias aos soldados americanos, desenvolveu-se o método audiolingual, baseado nas teorias behavioristas.

No Brasil, o ESP é sinônimo de leitura instrumental, e há quem considere o ensino instrumental de idiomas como ensino de leitura no idioma estrangeiro. No entanto, há discussões sobre os mitos existentes acerca dessa denominação, já que se pode ensinar língua com fins específicos sem negligenciar as demais habilidades, como a oralidade e a escrita, por exemplo.

O professor João Sedycias, da Universidade Federal de Pernambuco, diz que:

O inglês instrumental consiste, como a própria palavra denota, no treinamento instrumental dessa língua. É também conhecido como Inglês para Fins Específicos e tem como objetivo principal capacitar o aluno, num período relativamente curto, a ler e compreender o essencial para o desempenho de determinada atividade. $\mathrm{O}$ arcabouço metodológico no qual o ensino de inglês instrumental está fundamentado é em boa parte resultado de mais de vinte anos de pesquisas realizadas pelo Conselho Britânico com apoio do Ministério da Educação e colaboração de linguistas ingleses e brasileiros, principalmente da Universidade de São Paulo (USP) e da Pontifícia Universidade Católica de São Paulo (PUC-SP). ${ }^{32}$

No Brasil, portanto, a PUC-SP foi a instituição responsável pela implantação do ESP33 (CELANI et al., 1988; CELANI, 2009), e, para isso, foi criado, em 1980, o Projeto Nacional de Ensino de Inglês Instrumental em Universidades Brasileiras. O projeto foi executado entre 1980 e 1989 e tinha como objetivo melhorar o uso de inglês dos pesquisadores brasileiros,

32 Disponível em: http://descomplicandoingles.blogspot.com.br/2009/02/o-que-e-inglesinstrumental.html. Acesso em abril de 2012.

${ }^{33}$ English for Specific Purposes (Inglês para fins específicos ou inglês instrumental). 
professores e técnicos, especialmente no que diz respeito à leitura de publicações especializadas e técnicas (RAMOS et al, 2009).

Ainda segundo Celani (2009), o desenvolvimento do projeto aconteceu em duas etapas, sendo que, na primeira delas, foram realizadas visitas em instituições de ensino superior com o escopo de analisar as necessidades e os tipos de cursos que seriam ministrados, além de preparar a estrutura, professores e materiais adequados. Num segundo momento, houve a chegada de especialistas na abordagem instrumental para o ensino-aprendizagem do inglês. O termo "abordagem instrumental" nada mais é do que um sinônimo da expressão "ensino-aprendizagem de idiomas com fins específicos".

Atualmente, no Brasil, quanto ao ensino de ESP, há uma gama de instituições que oferecem cursos com abordagem instrumental nas mais variadas orientações e segmentos profissionais, por exemplo: inglês para garçons, taxistas, engenheiros, médicos, pilotos, juristas etc.

Já no tocante ao ensino do espanhol, há a denominação "ensino de espanhol instrumental" ou "ensino de espanhol para fins específicos". Nas décadas de 1960, 1970 e 1980, o ensino desse idioma ficou praticamente inerte, pois, nesse período, o importante era o estudo do inglês. Porém, na atualidade, podemos dizer que houve uma "explosão" de interesse pelo estudo do espanhol, principalmente em decorrência da abertura e da expansão das relações econômicas entre o Brasil e os países sul-americanos, sendo que o conhecido acordo do MERCOSUL ${ }^{34}$ teve relevante importância.

Podemos verificar o aumento do interesse pelo estudo do espanhol, sobretudo com o surgimento da lei 9394/96, que deixou, a critério de cada

\footnotetext{
34 Nota: O MERCOSUL, como é conhecido o Mercado Comum do Sul, é a união aduaneira (livre comércio intrazona e política comercial comum) de cinco países da América do Sul.
} 
escola, a escolha da língua estrangeira cujo estudo seria obrigatório a partir do quinto ano do ensino fundamental. Muitas escolas escolheram o espanhol, como segunda língua estrangeira, sendo que, anteriormente, somente existia o ensino do inglês. Além disso, o ensino da língua espanhola não se restringiu somente às escolas públicas, mas estendeu-se, também, às escolas e universidades particulares.

Paralelamente ao crescimento do número de pessoas interessadas no estudo do espanhol, podemos colocar em relevo os diferentes objetivos que cada aluno traz ao iniciar o estudo de um idioma estrangeiro: alguns estudantes pretendem desenvolver as quatro habilidades (falar, ler, escrever e compreender); outros, no entanto, têm interesse somente em desenvolver uma única habilidade, como a leitura, por exemplo; outros, ainda, visam à aprendizagem da língua para um fim específico (para o turismo, para os negócios, para a complementação da formação tecnológica ou acadêmica etc.).

Em relação ao português, Ana Maria Marques Cintra, em seu artigo "Português Instrumental: um percurso", faz um breve histórico sobre o trajeto trilhado pela abordagem instrumental no ensino da língua portuguesa, que, segundo a autora, significou "uma oportunidade para reorganizar o que foi feito, refletir sobre acertos e erros cometidos ao longo do tempo e dimensionar a importância de continuidade deste trabalho" (CINTRA, 2009, p. 47). Segundo essa estudiosa, a tarefa de ensinar a língua portuguesa foi iniciada basicamente "sob a égide da filologia", que, na verdade, era o que se conhecia naquele momento (final dos anos 1960 e início dos anos 1970). Porém, logo começou a surgir certa inquietação quanto à metodologia abordada, e 
consequentemente, as coisas tomaram um rumo diferente, conforme ela afirma:

Foi, pois, o resultado de um olhar curioso que nos levou a descobrir a abordagem instrumental pela via do ensino de inglês, na PUCSP. Embora sem o devido domínio da língua inglesa, sempre nos instigavam alguns aspectos que sabíamos estarem sendo trabalhados no curso de inglês e nos perguntávamos se não seria possível lançar mão de algumas orientações didáticas que davam resultado naquele curso, para construir caminhos alternativos para o português, língua materna. (CINTRA, 2009, p. 48)

Partindo do exemplo de como era ensinado o inglês instrumental e participando de cursos específicos, Cintra começou a abandonar o papel do professor "tradicional" para "assumir um papel de animador de um processo de ensino, segundo o qual caberia ao próprio aprendiz construir seu aprendizado”. (CINTRA, 2009, p. 49).

Com essa experiência, os pesquisadores puderam observar que foi necessário quebrar alguns paradigmas para que o novo experimento pudesse alcançar resultados práticos no ensino da língua materna, já que para o ensino de língua estrangeira funcionava significativamente. E, ainda de acordo com Cintra, foi necessário aprender a desenhar um curso após a "análise das necessidades" do grupo de alunos, ou seja, o curso era programado levando em consideração os aspectos analisados do perfil do grupo e as suas necessidades.

Assim, colocando o aluno como centro do processo de ensinoaprendizagem e considerando as suas experiências pessoais, ficou evidente que estas precisavam ser levadas para dentro da sala de aula. Quando o discente entra numa sala de aula, ele traz consigo toda a sua bagagem de vida, tudo o que já aprendeu, pois não lhe é possível desvencilhar-se de seus 
conhecimentos anteriores no momento em que aprende algo novo. Desse modo, cada indivíduo terá uma única percepção diante das atividades que lhe serão apresentadas:

Aprendemos, ao colocar o aluno como centro, que eram fundamentais, as ideias e experiências que ele carregava consigo para a sala de aula; a sua percepção e assunção da relevância do que se estava trabalhando para as finalidades do curso, a sua autoconfiança para assumir cada tarefa escolar como problema, cuja solução poderia ser dada em etapas e o desenvolvimento de suas potencialidades como indivíduo, de modo especial a criticidade e a criatividade." (CINTRA, 2009, p. 51)

Para tal professora, essa foi uma experiência válida, mesmo tendo os seus percalços, e em alguns contextos, não funcionando tão bem como o grupo de pesquisa tinha imaginado inicialmente. Afirma a autora:

Em síntese, o que a abordagem instrumental trouxe de inovação para o ensino de língua materna foi uma consciente mudança de atitude do professor para ensinar, uma clareza de que seria fundamental estabelecer objetivos alcançáveis e metas, em lugar de transcrição de planejamentos anteriores; uma certeza de que deveria transformar conhecimentos teóricos em ações práticas, em lugar de disponibilizar textos teóricos para os alunos e apenas discuti-los em sala de aula. (CINTRA, 2009, p. 52)

Acreditamos, portanto, que, para estabelecer metas e alcançá-las, é necessário que o professor reflita sobre o seu papel dentro da sala de aula e, como já dissemos anteriormente, faça uma análise das necessidades dos discentes para que possa encontrar o método/abordagem mais apropriado para cada grupo de alunos. 


\section{5- O italiano com fins específicos no Brasil}

O nosso interesse pelo ensino do italiano com fins específicos surgiu por causa da necessidade de comunicação dos discentes em determinados contextos específicos e que, muitas vezes, requer do professor uma análise mais apurada na preparação de um curso.

Como dissemos anteriormente, o processo de ensino pressupõe que se façam escolhas, e, por meio da análise das necessidades, podemos definir quais critérios adotar na programação de um curso. Sabemos que o termo "necessidade" é bastante genérico, pois, pode indicar tanto as necessidades linguísticas quanto as de natureza social ou psicológica. Para exemplificar, podemos dizer que um discente pode ter necessidade de adquirir conhecimentos com relação à estrutura gramatical, ou somente precisa conhecer o vocabulário específico relacionado ao âmbito profissional ou acadêmico em que ele atua (compreensão escrita), ou ainda, pode ter necessidade de se comunicar (compreensão e produção oral) com os seus pares, ou, ainda, pode precisar produzir documentos no idioma (produção escrita), por exemplo. A identificação das distinções de natureza motivacional, cognitiva e de experiências vivenciadas pelos discentes constitui um prérequisito importante para a diversificação do processo didático, que permite estabelecer uma ligação entre as necessidades individuais e os objetivos de ensino fixados pelo curso ou pela instituição de ensino.

Partindo-se da análise das necessidades, pode-se chegar a uma especificação dos objetivos de ensino, dentre os quais os escopos genéricos são redefinidos de maneira funcional para um determinado grupo de discentes. 
Como exemplo de objetivo específico, podemos citar a habilidade de entender e falar sobre um assunto de determinada natureza com certo grupo de pessoas, assumindo um papel pré-definido; ou, também, a necessidade de ler e compreender textos escritos. Dentro da seara dos objetivos específicos, encontra-se o ensino do italiano instrumental.

Pesquisando sobre o ensino do italiano com fins específicos, percebemos que o termo mais conhecido e usado no Brasil é "italiano instrumental". Mas encontramos, também, vários manuais de ensino do italiano voltados para um fim específico, a saber: italiano para negócios, italiano para juristas, italiano comercial, italiano para médicos etc. No entanto, a nosso ver, há uma diferença entre o "italiano instrumental" e a finalidade desses livros de italiano para fins específicos, porque o ensino do italiano instrumental, visa ao desenvolvimento da habilidade de leitura e compreensão de textos, enquanto esses manuais de italiano têm o objetivo de trabalhar as quatro habilidades em uma linguagem específica de determinada área, com mais profundidade, sendo pré-requisito que o aluno já tenha estudado o idioma e queira aperfeiçoar seus conhecimentos.

O termo instrumental - associado, tanto no português, no espanhol, no italiano ou no inglês, ao ensino de uma língua estrangeira - significa que essa língua serve de instrumento para alcançar determinados fins em um contexto universitário ou profissional específico. Fala-se de "italiano com fins específicos", embora cursos e textos recorram frequentemente a denominações como "italiano para a medicina", "italiano dos negócios" ou "italiano comercial", planejados para estudantes que já possuem certo nível de domínio da língua italiana e querem aprofundá-lo dentro de um contexto profissional específico. (FALIERE, ALLEN, 2011, p. 14 e 15).

Segundo Cintra (2009, p. 53), "o termo instrumental aplicado ao ensino de língua foi, durante um tempo, muito criticado, pois se admitia que estaria remetendo a um conjunto de técnicas mecanicistas". (CINTRA, p. 53). Essa 
autora considera absurda tal ideia, porque pondera sobre a questão de que técnicas mecanicistas não dependem de nomes, mas de atitudes:

Por isso não tememos o termo e o tomamos no sentido mais amplo de meio para se chegar a determinados fins práticos, razão pela qual se impõe uma prática centrada no aprendiz e um conjunto de atividades capazes de trabalhar habilidades cognitivas e metacognitivas, dado que se parte do que o aluno já sabe para ajudá-lo a construir novos conhecimentos, ou a buscar internalizar conhecimentos ainda periféricos. (CINTRA, 2009, p. 53)

Como já mencionado anteriormente, o maior enfoque dado ao estudo de idiomas com fins específicos, atualmente, dá-se na área de inglês; por esse motivo, ao iniciar a nossa pesquisa, encontramos com mais facilidade os trabalhos desenvolvidos nessa área. Além dos trabalhos realizados na área de inglês, como já foi dito, há uma grande tradição no estudo do francês instrumental.

Encontramos, também, felizmente, trabalhos realizados na área de ensino de italiano, e muitos deles feitos na Universidade de São Paulo. A professora Olga Alejandra Mordente, da área de Língua Italiana da USP, foi quem mais realizou trabalhos sobre o ensino instrumental nesse idioma. As pesquisas que realizamos no site da USP, no banco de dissertações e teses, levaram-nos aos trabalhos realizados por essa pesquisadora e por alguns de seus orientandos.

No trabalho "A linguagem e os elementos de cultura e de costumes, nos guias turísticos, para um ensino específico do italiano como segunda língua”, Mordente (2000) diz acreditar que:

Esta pesquisa contribua para uma imagem adequada, da realidade italiana aos olhos dos brasileiros, pois os guias turísticos da Península, através da linguagem e de aspectos étnicos nos permitem conhecer uma Itália mais autêntica, elementos que um curso para o ensino específico da língua italiana deveria apontar. [...] foram examinados diversos 
aspectos linguísticos $o$ qual envolve não somente a competência de leitura para se chegar aos diversos níveis de significação, mas também aos aspectos discursivos implícitos na linguagem.

Ao analisar o trabalho de pesquisa desenvolvido pela professora

Mordente, pudemos observar que o seu foco refere-se, principalmente, ao ensino do italiano por meio de guias turísticos. Usando esse material autêntico na preparação das aulas, a professora procurou examinar os diversos aspectos linguísticos que envolvem não somente a habilidade de leitura, mas também os aspectos discursivos implícitos na linguagem desses materiais.

Encontramos, no artigo 'L'insegnamento dell' italiano per scopi specifici: livello iniziale e avanzato", da mesma autora, uma afirmação muito esclarecedora quanto às finalidades de um curso de língua instrumental:

Em um curso de língua instrumental não podem faltar elementos culturais em sentido antropológico: para poder comunicar-se é necessário, de fato, conhecer as regras culturais presentes nas principais situações em que o aluno possa se encontrar [...] A língua estrangeira ensinada para fins específicos tem o objetivo de oferecer um aprendizado que permite utilizar com maior eficiência quaisquer $e$ todo documento escrito, oral, audiovisual na língua que se aprende. [...] A maioria dos livros didáticos não parece abranger satisfatoriamente a compreensão de textos e a habilidade para escrever. [...] Consequentemente, é necessário visar sobre aquele universo particular de interesses e preparar cursos com fins específicos. É importante, portanto, que sejam elaborados cursos com ênfase na habilidade que se apresenta como prioritária para os alunos no momento em que procuram o curso, que porém não excluam, a priori, as outras habilidades. ${ }^{35}$

\footnotetext{
${ }^{35}$ No original: In un corso di lingua strumentale non possono mancare elementi culturali in senso antropologico: per poter comunicare è infatti necessario conoscere le regole culturali presenti nelle principali situazioni in cui l'allievo può trovarsi. [...] La lingua straniera insegnata per fini specifici ha l'obiettivo di offrire un apprendimento che permetta utilizzare con maggior efficienza qualsiasi e ogni documento scritto, orale, audiovisivo nella lingua che si impara. [...] La maggioranza dei libri didattici non sembra che coprino soddisfacentemente la comprensione di testi e l'abilità per lo scritto. [...] In conseguenza, è necessario puntare su quell'universo particolare di interessi e preparare corsi per fini specifici. È importante, pertanto, che siano elaborati corsi con enfasi sull'abilità che si presenti come prioritaria per gli alunni nel momento
} 
De fato, o ensino da língua italiana com fins específicos deve absolutamente levar em conta elementos culturais e antropológicos, já que a comunicação seria deficiente sem o conhecimento de regras que envolvem determinadas situações com as quais o discente possa se deparar. Saber lidar com todo tipo de documento escrito, oral e audiovisual na língua que se aprende, é um ponto essencial no processo de aprendizagem de um idioma. No entanto, a maioria dos livros didáticos peca por não atender satisfatoriamente essas necessidades de aprendizagem. É necessário, portanto que sejam elaborados cursos em que se priorizem o desenvolvimento e o aperfeiçoamento das quatro habilidades, conforme explicitado no Quadro Comum Europeu de Referência. Salientamos que o ensino de idiomas com fins específicos não deveria seguir a abordagem/método tradicional de ensino baseado somente na gramática; deve levar em consideração o perfil do aluno e as suas necessidades. Devemos, também, utilizar material autêntico nas aulas, para que o aluno possa se habituar rapidamente à linguagem "não didatizada".

Outra pesquisa que encontramos e que nos interessou por sua temática foi a de Rosiléa Pizarro Carnelós; em 2005, ela desenvolveu junto ao Programa de Pós-graduação em Linguística da USP um trabalho intitulado Estudo contrastivo da fraseologia presente em documentos jurídicos redigidos em português, francês e italiano: implicações na tradução juramentada e proposta de vocabulário fraseológico jurídico trilíngue:

O objetivo deste trabalho foi realizar um estudo contrastivo da fraseologia presente em textos jurídicos redigidos em português, francês e italiano, apresentar uma reflexão sobre a tradução das unidades fraseológicas no âmbito da tradução

in cui cercano il corso, ma però che non escludano, a priori, le altre abilità. (MORDENTE, 2000). 
juramentada, bem como propor a elaboração de um vocabulário fraseológico jurídico trilíngue. Partindo-se de um corpus constituído de atas de assembléias, contratos comerciais, contratos sociais, estatutos e procurações, redigidos originalmente nos três idiomas, e de outro constituído de traduções juramentadas, procedeu-se à coleta de unidades fraseológicas, tanto as colocações adjetivas, adverbiais, nominais e verbais, quanto às lexias textuais em nível de sintagma e de texto, representativas da linguagem jurídica. Pelo cotejo das unidades fraseológicas selecionadas com aquelas encontradas nas traduções juramentadas analisadas, constatou-se que, quando da inexistência de equivalentes fraseológicos na língua-meta, é grande a tendência literalizante da tradução juramentada e, consequentemente, o cuidado com a preservação das características discursivas da língua-fonte.

Visto que trabalhamos com termos jurídicos, a tese de Carnelós (2005), que culminou na constituição de um vocabulário fraseológico trilíngue baseado nas unidades fraseológicas existentes em textos de natureza jurídica em três idiomas (italiano, português e francês), foi muito útil à nossa pesquisa. Segundo a autora:

Toda disciplina, toda área do conhecimento tem sua própria terminologia, e o direito não é exceção à regra. A terminologia jurídica é uma língua técnica que se insere na língua geral. A tradução do discurso jurídico pode suscitar problemas de pelo menos três naturezas: terminológica, fraseológica e jurídica (sistemas jurídicos diferentes, como direito romano e common law). (CARNELÓS, 2005, p. 28)

Ainda no departamento de Letras Modernas da USP, encontramos uma pesquisa de mestrado de uma orientanda da professora Mordente que resultou na dissertação Proposta para o ensino de italiano por meio da culinária (FREITAS,2008), a qual tinha o objetivo de:

Mudar a clássica sala de aula pela cozinha, a carteira pela mesa de jantar; no lugar do lápis a colher-de-pau e no lugar do livro didático um caderno de receitas... O objetivo principal dessa dissertação é propor um curso de língua italiana por meio da culinária que permita ao aluno desenvolver as quatro habilidades linguísticas de base: ouvir, falar, ler e escrever em língua estrangeira, nos parâmetros propostos pelo Quadro Europeu Comum de Referência para as Línguas. Para alcançar tal objetivo, o Capítulo I deste trabalho apresenta um breve panorama da culinária italiana, as influências e os sabores que contribuíram para a formação de uma cultura reconhecida 
mundialmente. O Capítulo II analisa as teorias de ensino/aprendizagem centradas no aluno, a didática da ação e a proposta do Quadro Europeu Comum de Referência para as Línguas. A partir da fundamentação teórica apresentada nos dois primeiros capítulos, foi levantada a hipótese de que o aluno brasileiro se identifica com a culinária italiana e essa constitui uma motivação muito válida na aquisição/aprendizagem da língua italiana ainda na fase inicial de estudo. O Capítulo III apresenta o percurso de elaboração do curso: a análise dos livros didáticos, a definição dos objetivos e dos conteúdos e a sistematização das unidades didáticas. O quarto e último capítulo é dedicado à apresentação do curso experimental de italiano por meio da culinária. O curso foi realizado com estudantes de primeiro nível que encontraram na proposta uma oportunidade de conhecer melhor a cultura e os hábitos de um povo, e de adquirir/aprender os conceitos fundamentais da língua italiana.

A autora, apesar de usar a linguagem setorial da culinária, procurou ensinar o italiano trabalhando as quatro habilidades do idioma, de acordo com as orientações do Quadro Comum Europeu. Ela mesma, no terceiro capítulo, define a sua posição como formativa-comunicativa e não instrumental:

Sabemos que o percurso para a aquisição da língua será permeado pela terminologia alimentar, mas isso não impede de formar o aluno em todas as habilidades, ler, falar, escrever e entender a LE. A língua do setor culinário que contém maior ligação com a língua geral, será utilizada na preparação do aluno para os diferentes atos comunicativos, proposta de um curso regular de língua. (FREITAS, 2008, p. 61)

Pesquisando não apenas na área de didática das línguas estrangeiras, mas também em outras áreas, encontramos o Grupo de Trabalho sobre Lexicologia, Lexicografia e Terminologia (GTLEX) da Associação Nacional de Pós-Graduação e Pesquisa em Letras e Linguística (ANPOLL), que desenvolve pesquisas relacionadas ao uso das línguas de especialidades. Para esse grupo, "o principal objetivo da Terminologia é dar conta do funcionamento das unidades lexicais especializadas em situações comunicativas profissionais, acadêmicas ou científicas". Uma das acepções da terminologia refere-se ao 
conjunto vocabular próprio de uma ciência, técnica, arte ou atividade profissional; assim, é possível falar em terminologia da Informática, da Biotecnologia, do Direito, da Música, etc ${ }^{36}$.

O trabalho desenvolvido por tal grupo é muito relevante, pois oferece instrumentos de pesquisa que podem facilitar $o$ trabalho de tradutores $e$ professores de idiomas e que favorecem o ensino de línguas com fins específicos.

A seguir, mencionamos algumas pesquisas realizadas pelo GTLEX as quais englobam o uso da língua italiana ${ }^{37}$ :

\begin{tabular}{|c|c|c|c|}
\hline MACROTEMAS & $\begin{array}{c}\text { PROJETOS } \\
\text { Título e vigência }\end{array}$ & MEMBROS DO GT & PRODUTOS ESPERADOS \\
\hline $\begin{array}{l}\text { Lexicografia } \\
\text { pedagógica }\end{array}$ & $\begin{array}{c}\text { Dicionários temáticos } \\
\text { ilustrados bilíngues para } \\
\text { os níveis de aprendizagem } \\
\text { básico, intermediário e } \\
\text { avançado }\end{array}$ & $\begin{array}{l}\text { Claudia Zavaglia } \\
\text { Claudia Maria Xatara }\end{array}$ & $\begin{array}{l}\text { Publicação de artigos e da } \\
\text { coleção de dicionários } \\
\text { (português - alemão, } \\
\text { português - árabe, } \\
\text { português - espanhol, } \\
\text { português - francês, } \\
\text { português - inglês, } \\
\text { português - italiano, } \\
\text { português - japonês) }\end{array}$ \\
\hline \multirow[t]{3}{*}{$\begin{array}{l}\text { Lexicografia } \\
\text { bilíngue }\end{array}$} & $\begin{array}{l}\text { Guia dos curiosos: } \\
\text { xeretando a linguagem }\end{array}$ & $\begin{array}{l}\text { Adriana Zavaglia } \\
\text { Claudia Maria Xatara } \\
\text { Claudia Zavaglia }\end{array}$ & $\begin{array}{c}\text { Publicação de artigos e da } \\
\text { coleção "Xeretando a } \\
\text { linguagem" (espanhol, } \\
\text { francês, inglês, italiano, } \\
\text { latim) }\end{array}$ \\
\hline & $\begin{array}{c}\text { Dicionário Multilíngue de } \\
\text { Cores }\end{array}$ & $\begin{array}{l}\text { Adriana Zavaglia } \\
\text { Claudia Zavaglia }\end{array}$ & $\begin{array}{c}\text { Publicação de artigos e do } \\
\text { dicionário e elaboração de } \\
\text { dissertações }\end{array}$ \\
\hline & $\begin{array}{c}\text { Vocabulário erótico- } \\
\text { obsceno português - } \\
\text { italiano e italiano - } \\
\text { português }\end{array}$ & Claudia Zavaglia & $\begin{array}{l}\text { Publicação de artigos e do } \\
\text { vocabulário e elaboração } \\
\text { de dissertação e tese }\end{array}$ \\
\hline $\begin{array}{c}\text { Corpora de textos } \\
\text { especializados }\end{array}$ & $\begin{array}{c}\text { Elaboração de Corpora } \\
\text { paralelos - ECOPA }\end{array}$ & Claudia Zavaglia & $\begin{array}{l}\text { Publicação de artigos e } \\
\text { elaboração de dissertação }\end{array}$ \\
\hline $\begin{array}{c}\text { Padrões da } \\
\text { linguagem técnico- } \\
\text { científica }\end{array}$ & $\begin{array}{l}\text { ProjeCOM: Combinatórias } \\
\text { léxicas especializadas da } \\
\text { linguagem legal, normativa }\end{array}$ & $\begin{array}{l}\text { Anna Maria Becker } \\
\text { Maciel } \\
\text { Cleci Regina }\end{array}$ & \\
\hline
\end{tabular}

${ }^{36}$ Disponível em:

http://www.letras.ufmg.br/gtlexNovo/CMS/index.asp?pasta=gtlexnovo\&path=2013430155119.as p\&title=Terminologia\&id=60. Acesso em 28 de novembro de 2013.

${ }^{37}$ Disponível em:

http://www.letras.ufmg.br/gtlexNovo/CMS/index.asp?pasta=gtlexnovo\&path=2013625212956.as p\&title=Projetos\%20em\%20Execu\%E7\%E3o\&id=62. Acesso em 28 de novembro de 2013. 


\begin{tabular}{|c|c|c|c|}
\hline & e científica & $\begin{array}{c}\text { Bevilacqua, Cláudia } \\
\text { Mendonça Scheeren, } \\
\text { Maria José Bocorny } \\
\text { Finatto } \\
\text { Patrícia Chitoni } \\
\text { Ramos Reuillard } \\
\end{array}$ & \\
\hline $\begin{array}{c}\text { Pedagogia de } \\
\text { linguagens de } \\
\text { especialidade }\end{array}$ & $\begin{array}{l}\text { Elaboração de modelos } \\
\text { de transmissão/ } \\
\text { constituição de } \\
\text { conceitos e termos de } \\
\text { áreas técnicas e } \\
\text { científicas }\end{array}$ & $\begin{array}{c}\text { Maria Aparecida } \\
\text { Barbosa, Jeni Silva } \\
\text { Turazza, Alice Maria } \\
\text { Teixeira de Sabóia, } \\
\text { Maria Margarida de } \\
\text { Andrade, Rosiane } \\
\text { Cristina Gonçalves } \\
\text { Braga, Guiomar } \\
\text { Fanganiello Calçada, } \\
\text { Antonieta Laface e } \\
\text { alguns orientandos } \\
\text { de todas essas } \\
\text { docentes }\end{array}$ & $\begin{array}{c}\text { Publicações de natureza } \\
\text { pedagógica para } \\
\text { estudantes do terceiro } \\
\text { grau }\end{array}$ \\
\hline
\end{tabular}

Como já mencionado, as nossas principais fontes de pesquisa foram, basicamente, dissertações, teses, monografias e artigos disponíveis em formato eletrônico, no entanto, ao realizar a busca na biblioteca da Faculdade de Filosofia, Letras e Ciências Humanas da Universidade de São Paulo, pudemos perceber a grande contribuição da professora Olga Mordente, que pesquisou o assunto com relevante clareza e escreveu vários textos a respeito dele.

\section{6- Uma visão geral e propostas de trabalho}

Conforme já dissemos, encontramos poucos pesquisadores no Brasil que se dedicaram ao ensino-aprendizagem do italiano com fins específicos. Queremos salientar que muitos professores dedicam-se ao ensino da língua italiana para profissionais de diversas áreas e ministram, também, aulas de italiano com fins específicos a advogados, juízes e estudantes de Direito. Em 
São Paulo, por exemplo, o Instituto Cultural Ítalo-Brasileiro ${ }^{38}$ oferece cursos de italiano jurídico.

No entanto, em âmbito de pesquisa acadêmica, principalmente na Universidade de São Paulo (USP), não encontramos nenhum trabalho realizado com o objetivo de avaliar a metodologia e os materiais utilizados no ensino do italiano jurídico. A nossa referência, portanto, na USP, foi a pesquisa realizada pela professora Mordente, e, além disso, neste trabalho, procuramos basear-nos nas teorias de alguns autores italianos, já mencionados.

Diante de todo o exposto, decidimos realizar a nossa própria pesquisa para analisarmos os dados e podermos chegar a conclusões quanto ao ensinoaprendizagem do italiano jurídico. Elaboramos, portanto, uma pesquisa de campo, que se desenvolveu em duas etapas.

Em primeiro lugar, preparamos um curso de italiano para alunos que já tinham o nível intermediário de conhecimento da língua italiana e atuavam na área jurídica. Esse curso foi ministrado na Casa do Advogado de Jundiaí-SP e será descrito com maiores detalhes mais adiante.

Em segundo lugar, preparamos um curso para alunos com o nível iniciante, sem conhecimento da língua italiana, mas que frequentavam a faculdade de Direito. Esse curso foi ministrado para os alunos de graduação e pós graduação da Faculdade de Direito do Largo São Francisco (USP).

Cada uma das etapas foi subdividida em três fases, que descrevemos a seguir:

A primeira fase refere-se à análise da produção oral e escrita do grupo de alunos de nível intermediário, no qual usamos os dois manuais (Italiano per

38 Disponível em: http://www.icib.com.br/site/. Acesso em outubro 2012. 
giuristi e Una lingua in Pretura), que serão apresentados no próximo capítulo. Essa análise foi feita com base na participação dos estudantes nas atividades propostas por esses livros e levou em conta os seguintes critérios: a compreensão oral e escrita, a produção oral e escrita, a gramática, o vocabulário geral e o específico. Utilizamos, além dos dois manuais mencionados um livro bastante conhecido no âmbito jurídico e que foi escrito por Piero Calamandrei, Elogio dei giudici scritto da un avvocato.

Na segunda fase, fizemos a análise da compreensão oral e escrita do grupo de alunos iniciantes, com os quais usamos atividades de nível básico; algumas delas foram elaboradas por nós. Além de adotarmos um manual básico de gramática italiana (Espresso A1), utilizamos também o livro Italiano per giuristi. Apesar deste último ser indicado para alunos que já tenham conhecimento da língua italiana, decidimos fazer uma experimentação, utilizando-o com os alunos de nível iniciante.

Para desenvolver a análise, baseamo-nos nos postulados de Paolo Balboni (2009), segundo os quais às habilidades primárias (ler, compreender o que se ouve, falar e escrever) sobrepõem-se as habilidades integradas, e todas são trabalhadas em conjunto. Essa integração torna-se evidente se colocada no eixo receptivo-produtivo, possibilitando ao aprendiz:

-saber dialogar, o que não é uma simples soma de escuta e produção;

-saber parafrasear oralmente e por escrito;

-saber resumir oralmente e por escrito;

-saber tomar notas; 

$13)^{39}$

-saber escrever por meio de ditado; (BALBONI, 2009, p.

Levando em consideração os aspectos do saber receptivo-produtivo, na terceira fase, avaliamos o trabalho desenvolvido com cada um dos grupos e chegamos a algumas conclusões.

O nosso objetivo foi avaliar os materiais didáticos em dois momentos distintos: primeiramente, partindo das análises preliminares dos livros acima apontados tentamos identificar, com base no perfil do aluno mencionado nestes, as possíveis dificuldades de produção oral e escrita dos discentes. Para isso, realizamos todas as atividades programadas para as aulas, e a partir do nosso próprio desempenho fizemos suposições sobre quais seriam as dificuldades dos alunos. No entanto, chegamos a um resultado real somente durante as aulas, enquanto os alunos faziam os exercícios propostos e esclareciam as dúvidas.

Em segundo lugar, desenvolvemos uma pesquisa direcionada ao ensino do italiano jurídico para alunos principiantes no idioma, visando avaliar quais atividades didáticas poderiam ser propostas de modo a levar em consideração as questões específicas do italiano jurídico sem, no entanto, desprezar o ensino da estrutura da língua.

Ao longo de dois semestres de curso (mais precisamente, oito meses), avaliamos os trabalhos dos alunos iniciantes, verificando o que conseguiam produzir oralmente e por escrito e observando, nessas produções, não só o uso de termos jurídicos como também o uso da língua italiana.

\footnotetext{
${ }^{39}$ No original: -saper dialogare, che non è una semplice somma di ascolto e produzione, -saper parafrasare oralmente e per iscritto, -saper riassumere oralmente e per iscritto, -saper prendere appunti, saper scrivere sotto dettatura.
} 
Para analisarmos as produções dos estudantes, coletamos textos escritos por eles. Para analisarmos a produção oral dos discentes, filmamos algumas apresentações orais deles. Além disso, usamos um diário de campo, no qual fizemos anotações acerca das aulas e analisamos, também, a aplicação dos materiais didáticos elaborados por nós. 


\section{2- ANÁLISE DE MATERIAIS}

Faremos, aqui, uma breve apresentação do material que utilizamos durante os cursos que preparamos e ministramos para realizar nossa pesquisa de campo. Em primeiro lugar, apresentaremos dois manuais didáticos que são específicos para o ensino do italiano jurídico: Una lingua in Pretura e Italiano per giuristi, ambos formulados e editados na Itália. O primeiro foi compilado pela Università per Stranieri di Siena (Bonacci), e o segundo pelos docentes de Direito da Università di Parma.

Claro está que esses dois manuais são direcionados a um público com conhecimento prévio de gramática italiana e conhecimentos específicos de Direito. O objetivo é o aprofundamento do estudo do idioma para atuar em contextos que exijam o uso de conteúdo jurídico. Fizemos uma análise premilinar, mas todas as atividades foram analisadas em nossa pesquisa de campo, pelo método empírico, o que mostraremos, posteriormente, com maiores detalhes.

Além desses dois manuais didáticos, escolhemos trabalhar também, (com o grupo de nível intermediário), com o livro Elogio dei giudici scritto da un avvocato, de Piero Calamandrei, que conta com uma versão para o português intitulada Eles, os juízes, vistos por um advogado. Como a nossa pesquisa foi elaborada em duas etapas (primeiro, fizemos uma pesquisa com alunos de nível intermediário e, posteriormente, com alunos de nível iniciante), usamos também um livro de gramática básica, com o grupo de alunos iniciantes. $\mathrm{O}$ manual que escolhemos foi o Espresso 1, (corso di italiano, nível A1), editado pela Alma Edizione, do qual falaremos mais adiante. 


\section{1- Una lingua in Pretura}

O livro Una lingua in Pretura (SEMPLICI, 1996) é estruturado em doze unidades didáticas, das quais sete iniciam-se com textos escritos, e cinco, com textos orais; juntas, as unidades abrangem os diversos ramos das Ciências Jurídicas. Depois das primeiras duas unidades introdutórias sobre os direitos e deveres do cidadão e sobre as ciências e os ramos do Direito, são apresentados assuntos específicos de direito privado, direito público, direito romano, direito penal e direito do trabalho, retirados diretamente da Constituição Italiana, do Código Civil ou de livros de estudo universitário.

O livro Una lingua in Pretura foi elaborado pelos docentes da Università per Stranieri di Siena com o objetivo de atender um público específico, ou seja, todos os interessados na língua do Direito. O perfil do aluno indicado pelo livro é o estudante com conhecimento intermediário de língua italiana e noção da linguagem jurídica. Por tal motivo, utilizamos esse livro somente com o grupo de nível intermediário, no curso realizado na $O A B$ de Jundiaí, e todas as observações referentes às atividades realizadas dizem respeito a esse grupo. Paolo Balboni, no prefácio de tal livro, faz a seguinte observação, que consideramos muito pertinente:

Com Una lingua in Pretura procurou-se, principalmente, satisfazer as exigências de todos os interessados na língua do direito, colocando à disposição, tanto de quem ensina como de quem deseja estudar tal linguagem, um manual específico, que serve também a uma possível utilização autodidata. (BALBONI, 1996, p. 12 $)^{40}$.

\footnotetext{
${ }^{40}$ No original: Con Una lingua in Pretura si è cercato in particolare di soddisfare le esigenze di tutti coloro che sono interessati alla lingua del diritto, mettendo a disposizione sia di chi insegna che di chi desidera studiare tale linguaggio uno specifico manuale, che si presta tra l'altro anche ad una possibile utilizzazione in autoapprendimento.
} 
Os elementos trabalhados mais detalhadamente nas unidades são os gramaticais e os lexicais; é o que se observa ao se analisar o índice das unidades. No entanto, pela ordem dos exercícios, nota-se que as atividades do livro abordam a compreensão escrita, a produção escrita e a produção oral.

Tomamos como exemplo a segunda unidade, na qual os elementos gramaticais apresentados são: presente indicativo, particípio passado, adjetivos e pronomes demonstrativos e advérbios de modo. Do ponto de vista lexical, os elementos abordados são: parlamento, lei, direito, ramo jurídico, regra geral abstrata, regra concreta, aplicar, princípio, jurisprudência, vigente, disciplina, legislador, autonomia, igualdade, consentimento mútuo, Estado, direito público, direito privado, ilícito, autoridade, direito constitucional, direito civil, direito administrativo, direito penal, direito processual, direito comercial, direito do trabalho, ente público.

A primeira atividade é um exercício de pré-leitura. A própria explicação sobre o desenvolvimento da atividade aponta que o texto apresentado é uma introdução ao Direito, na qual se discorre sobre regras jurídicas. O discente é orientado a observar com atenção as palavras e expressões que o ajudarão a entender o texto, conforme podemos observar na figura a seguir: 


\section{ATtività 1}

$\|$ brano che ti presentiamo in questa unità è una introduzione al Diritto nella quale si parla delle regole giuridiche.

Prima di leggere il brano osserva attentamente le seguenti parole ed espressioni, che possono aiutarti a capire il testo.

- Parlamento:

- giuridico:

- formulare una legge o una regola:

- applicare una legge o una regola: organo dello Stato che svolge la funzione legislativa. cioè ha il compito di fare le leggi.

che riguarda il diritto.

esprimere una legge o una regola con termini specific del linguaggio giuridico.

mettere in atto una legge o una regola.

Figura 1- atividade 1, p. 10 do livro Una lingua in Pretura.

Ao desenvolvermos essa atividade com os alunos durante a aula, observamos que eles compreenderam com facilidade os termos reportados, e a proposta do exercício foi atendida.

Quando os discentes passaram efetivamente à leitura do texto, propusemos que a atividade fosse desenvolvida em três fases, sendo que a primeira delas foi uma leitura geral para a compreensão global do assunto. Durante essa leitura, os estudantes foram orientados a grifar as palavras e expressões desconhecidas por eles, para analisá-las posteriormente. A partir dessa leitura inicial, os alunos já podiam fazer comparações com os textos jurídicos em português que tratavam do mesmo assunto e discutiram o texto com os colegas, sem a interferência do professor. Na segunda fase, os estudantes esclareceram suas dúvidas lexicais, usando um dicionário ou consultando o professor. Quando, finalmente, as dúvidas de léxico foram esclarecidas, os aprendizes fizeram uma leitura em voz alta para praticarem a pronúncia das palavras e para que corrigíssemos eventuais falhas de 
leitura (erros de acentuação da sílaba tônica, por exemplo), concluindo, assim, a terceira fase. Em todos os textos dessa unidade, os autores do livro seguiram o mesmo formato, propondo atividades de leitura e compreensão escrita. Como podemos observar na atividade que segue:

\section{ATrività 2}

Leggi il brano, poi indica se le seguenti affermazioni sono vere o false.

\section{Regole giuridiche}

È regola giuridica (regola di comportamento assistita dalla forza dello Stato) la regola contenuta in una legge del Parlamento. Tra regola generale e astratta e regola concreta vi è una differenza non piccola. La regola generale e astratta è quella regola formulata in termini tali da poter essere applicata un numero indeterminato di volte: essa dunque, per questa sua qualità, è generale perché si applica ad una generalità di persone (non a questa o a quella in particolare), ed è astratta perché non si riferisce ad una situazione già verificatasi, ma ad indeterminate situazioni future.

Esattamente all'opposto la regola concreta si riferisce a quella o quell'altra persona determinata e, in genere, integra una regola generale e astratta con alcuni elementi particolari che si possono applicare solo a quel caso concreto considerato. Per conseguenza la regola generale e astratta si applica un numero indeterminato di volte, la regola concreta si applica a quel caso determinato e muore con il finire di quel caso.

G.U. Rescigno, Manuale di diritto pubblico, Bologna, Zanichelli. 195: ₹: : : : :

Figura 2 - atividade 2, p. 10 do livro Una lingua in Pretura.

$\mathrm{Na}$ atividade 2, logo após a compreensão textual, há uma atividade de fixação do conteúdo visto: 
a. Una regola giuridica è una regola di comportamento stabilita dallo Stato.

Q $\square$

V

I di volte.

d. La regola generale e astratta si riferisce a situazioni determinate.<smiles>[Hg]</smiles>

(1)

e. La regola concreta si riferisce a un caso determinato.
V

Figura 3- atividade 2, p. 11 do livro Una lingua in Pretura.

Quanto à compreensão do léxico comum, pudemos observar que a atividade 3 procura trabalhar o léxico do texto usando sinônimos e indicando aos estudantes que devem usar o dicionário para pesquisar as palavras que não conhecem. Os alunos deste grupo estão habituados a utilizar o dicionário como um instrumento de auxílio durante as aulas: em sua rotina profissional, tais discentes consultam os códigos para o andamento dos processos; da mesma forma, nas aulas, consultam o dicionário para o desenvolvimento dos exercícios. 


\section{Atrività 3}

S chiamano sinonimi le parole che hanno lo stesso significato o significato simile. Per esempio "arriare" e "giungere" sono sinonimi.

T: presentiamo una lista di parole. Scegli, tra i tre termini che seguono ogni parola, il sinonimo di ognura. Ricorda che devi scegliere il sinonimo facendo riferimento al brano letto. Se non conosci il signifizato delle parole cercalo sul dizionario.
a. regola:
norma
formula
metodo
b. generale:
particolare
generico
$\checkmark$ comune
c. astratto:
$\square$ generale
irreale
distratto
d. concreto:
$\square$ solido
$\square$ reale
$\square$ compatto
e. determinato:
$\checkmark$ particolare
deciso
stabilito
f. caso:
$\square$ occasione
possibilità
$\checkmark$ situazione
g. integrare:
$\square$ collegare
$\checkmark$ completare
stabilire
h. verificarsi:
controllarsi
regolarizzare
accadere

Figura 4- atividade 3, p. 11 do livro Una lingua in Pretura.

A partir das palavras do léxico comum fixadas na atividade 3 , desenvolve-se a atividade número 4 , em que se trabalha a produção escrita: os alunos devem escrever uma frase com cada uma das palavras examinadas no exercício anterior. A atividade 5 dá continuidade ao trabalho com a produção escrita e propõe, também, um trabalho referente às diferenças lexicais.

Percebemos que os autores procuraram intercalar atividades de préleitura (atividade 1), compreensão escrita (atividades 2-6-14), léxico especial/setorial (atividade 8), produção escrita (atividades 4-5-7-9-13-14), léxico comum (atividades 3-7-10), morfologia e sintaxe (atividades 11-12). No 
entanto, a nosso ver, faltaram atividades visando à produção oral; por esse motivo, a cada atividade de compreensão escrita, propusemos aos discentes

uma atividade de produção oral, em que eles deveriam comparar os elementos

do Direito italiano aos do Direito brasileiro. Uma das atividades propostas foi desenvolvida a partir do texto da atividade 6:

\section{Atrività 6}

Adesso che sai cos'è una regola giuridica leggi il seguente brano che parla dei rami del diritto. Poi completa le frasi che seguono. Scegli l'alternativa corretta tra le tre proposte.

La scienza che si occupa essenzialmente delle regole generali e astratte così come sono state formulate dal legislatore (nel senso più ampio del termine) è la scienza del diritto o scienza giuridica (giurisprudenza invece in Italia indica il diritto interpretato dai giudici, l'opinione dei giudici rispetto alle regole generali e astratte).

5. Spesso anziché scienza del diritto o scienza giuridica si usa puramente e semplicemente la parola «diritto», aggiungendo quasi sempre la specificazione del ramo del diritto a cui ci si riferisce (e cioè diritto civile o privato, diritto commerciale, diritto costituzionale ecc.). Così la parola «diritto» acquista un significato per lo meno duplice: ora designa l'oggetto della conoscenza, la parte di realtà che

10. vogliamo studiare (e cioè l'insieme di quelle regole generali e astratte che compongono il diritto); ora designa la disciplina scientifica che studia tale oggetto L'insieme delle regole generali e astratte vigenti in un certo paese costituisce il diritto di tale paese. Questo diritto però si applica a sfere diverse della realtà sociäle e talvolta, proprio per questa diversità, presenta differenze di principio tra ramo e

15. ramo del diritto. Così ad esempio, venendo alla divisione fondamentale entro il diritto moderno, quella tra diritto privato da un lato e diritto pubblico dall'altro, il diritto privato, che si riferisce essenzialmente ai rapporti tra privati posti in condizioni di eguaglianza giuridica (nessuno può comandare sull'altro, ma i privati si obbligano l'uno verso l'altro solo per mutuo consenso), è governato dal principio

20. della autonomia privata, per cui il privato detta le regole a se stesso; nel diritto pubblico invece prevale il momento dell'autorità, per cui il soggetto pubblico può imporre unilateralmente la sua volontà ai cittadini. Le principali partizioni entro il diritto privato sono quelle di diritto civile, diritto commerciale, diritto del lavoro; entro il diritto pubblico sono quelle di diritto costituzionale, diritto amministrativo,

25. diritto penale, diritto processuale penale, diritto processuale civile. A parte sta il diritto internazionale (pubblico), che non è diritto di uno Stato, ma diritto dell'ordinamento internazionale composto dagli Stati.

Figura 5- atividade 6, p. 13 do livro Una lingua in Pretura.

Como podemos observar, o texto tem como assunto "os ramos do

direito". A partir do exercício de compreensão do texto, fizemos na lousa um 
esquema sobre os ramos do Direito italiano. Para fazer tal esquema, contamos com a participação dos aprendizes: eles nos indicavam os ramos do Direito italiano e nós escrevíamos o que eles diziam. Durante essa atividade, os alunos perguntavam uns aos outros quais as diferenças entre os ramos do Direito italiano e do brasileiro e se naquele, havia, ou não, determinado ramo; os estudantes formularam perguntas como: Quali rami fanno parte del diritto privato italiano? / Quali sono i rami del diritto pubblico italiano? Quando o aluno interpelado respondia, colocávamos a resposta dele no esquema desenhado na lousa. Essa atividade oral foi complementada após a leitura da atividade 14, em que encontramos as definições dos vários ramos do Direito italiano, conforme segue: 


\section{Atrività 14}

Leggi le seguenti definizioni dei vari rami del diritto.

A questo punto sei in grado di fare una breve esposizione scritta o orale sui vari rami in cui si divide il diritto.

Questa attività, che è facoltativa, rappresenta un ampliamento dell'attività 9. Può essere svolta sia individualmente che in gruppo e puo essere effettuata come esercitazione in classe o come attività di rinforzo delle strutture e dei contenuti appresi in questa unità, da eseguire a casa.

Costituzionale, diritto - disciplina giuridica che studia i principi fondamentali dell'ordinamento giuridico, le fonti del diritto, la struttura e le funzioni degli organi dello Stato, i rapporti fra lo Stato e gli enti pubblici ...

Amministrativo, diritto - branca del diritto pubblico che concerne i modi e le forme secondo cui la pubblica amministrazione si organizza.

Penale, diritto - complesso delle norme giuridiche che prevedono i fatti illeciti (reati), per i quali sono previste conseguenze penali (pene e misure di sicurezza).

Processuale civile, diritto - ramo del diritto pubblico che regola to svolgimento del processo civile.

Processuale penale, diritto - ramo del diritto pubblico che regola lo svolgimento dei processi penali, costituito dal complesso delle norme giuridiche per l'accertamento del reato.

Civile, diritto - branca del diritto riguardante tutti i rapporti giuridici che si istituiscono tra $\mathrm{i}$ privati, ad eccezione delle operazioni economiche attinenti al commercio, all'industria e alle attività professionali che costituiscono oggetto del diritto commerciale.

Commerciale, diritto - branca del diritto privato che disciplina i rapporti tra imprese commerciali, industriali, bancarie, e quelli che si instaurano tra le stesse imprese e il pubblico dei risparmiatori e consumatori.

Lavoro, diritto del - branca del diritto di formazione recente. Esso costituisce una conseguenza della rivoluzione industriale che ha determinato la creazione di una nuova classe sociale: il proletariato. Nell'ambito del diritto del lavoro si opera, generalmente, una tripartizione in legislazione sociale, diritto sindacale, e norme sul contratto di lavoro.

Figura 6- atividade 14, p. 19 do livro Una lingua in Pretura.

A nosso ver, considerando que o presente manual trata de forma didatizada os assuntos concernentes ao Direito italiano, acreditamos que 
atende o seu objetivo, ou seja, consegue transmitir os conceitos de Direito em uma linguagem própria para alunos que ainda não atingiram a fluência em língua italiana.

\section{2- Italiano per giuristi}

O livro Italiano per giuristi (FORAPANI, 2005), subdivide-se em quinze unidades que tratam dos assuntos típicos do âmbito jurídico, previamente escolhidos por docentes de Direito da Università di Parma, a saber: o sistema jurídico italiano, a leitura das fontes, a hierarquia das fontes, o direito constitucional, a comparação entre o direito romano germânico e o direito anglo-saxão, o direito civil, o direito comercial, o processo civil e o processo penal.

A Alma Edizioni lançou uma coleção voltada ao estudo de línguas específicas. Faz parte dessa coleção o livro Italiano per giuristi, que, segundo a autora, tem o objetivo de:

...fornecer estratégias úteis para a compreensão de textos de argumento jurídico nos quais recorra a uma fraseologia e uma terminologia específica, procurando unir o rigor científico com a necessidade de tornar prazeroso e estimulante o estudo de um argumento tão complexo. (FORAPANI, 2003) ${ }^{41}$

Observamos que, antes da primeira unidade, intitulada "O sistema jurídico italiano", há uma explicação sobre estratégias de leitura e técnicas de memorização do vocabulário, as quais têm como objetivo ilustrar um método

\footnotetext{
${ }^{41}$ No original: ... fornire strategie utili per la comprensione di testi di argomento giuridico nei quali recorra una fraseologia ed una terminologia specifica, cercando di unire il rigore scientifico con la necessità di rendere piacevole e stimolante lo studio di un argomento così complesso.
} 
para a leitura de textos específicos. Esse método (o SQ3R ${ }^{42}$ ) foi desenvolvido por Robinson em 1970 (FORAPANI, 2005) e adaptado para a finalidade do manual, o qual consiste na didatização da linguagem jurídica. Pudemos notar que a primeira unidade didática abre-se com uma atividade de compreensão da terminologia jurídica; em seguida, apresenta-se um texto com um esquema das ramificações do direito privado. Pudemos observar, também, que, basicamente, os exercícios propostos são de compreensão e fixação do léxico; ao final da unidade, há um gráfico de recapitulação do conteúdo, para que se possa avaliar o que foi apreendido pelo discente.

Optamos pela unidade número 8 ("Diritto Civile - La struttura del contratto") para fazer a nossa análise quanto às atividades propostas pelo manual. $\mathrm{O}$ grupo de alunos com o qual fizemos a nossa primeira análise é o mesmo com que fizemos a análise do livro Una lingua in Pretura: cinco estudantes, todos advogados, todos no nível intermediário. Mas, quando fizemos a análise abaixo, eles já estávamos no quarto mês de curso, iniciando o terceiro módulo.

O primeiro exercício da unidade 8 é a tradução de um termo técnico. Pede-se que se consulte o dicionário e se traduza a palavra "contratto". Para o estudante brasileiro, esse vocábulo não apresenta nenhuma dificuldade de compreensão, porque o termo é muito claro, até mesmo para um leigo.

Compreender a terminologia jurídica por meio de um artigo de lei é o exercício de pré-leitura proposto pela unidade. Conforme podemos ver a seguir, a autora reproduziu o artigo 1321 do Código Civil italiano, em que há a explicação do termo jurídico contratto e, para que o aluno consiga entender

${ }^{42}$ A sigla provém das cinco etapas das técnicas: sondagem (survey), questionamento ou perguntar (question), leitura ativa (read) e recitar (recite). 
todos os detalhes implicados no texto de lei, a atividade seguinte propõe uma reflexão sobre o significado de cada expressão importante contida no texto:

\section{Comprendere la terminologia giuridica}

Leggi l'art. 1321 del Codice civile e collega le espressioni del testo con il significato corretto, come nell'esempio.

\begin{tabular}{c|c|c|c}
\hline $\begin{array}{c}\text { Codice } \\
\text { Civile }\end{array}$ & Libro IV & $\begin{array}{c}\text { Titolo II } \\
\text { Dei contratti in generale }\end{array}$ & $\begin{array}{c}\text { Capo I } \\
\text { Disposizioni preliminari }\end{array}$ \\
\hline
\end{tabular}

Art. 1321 Nozione2 - - Il contratto è l'accordo di due o più parti per costituire, regolare o estinguere tra loro un rapporto giuridico patrimoniale.

\begin{tabular}{l|l}
\multicolumn{1}{c|}{ espressione del testo } & \multicolumn{1}{c}{ significato } \\
\hline $\begin{array}{l}\text { 1. parti } \\
\text { 2. costituire (un rapporto) }\end{array}$ & $\begin{array}{l}\text { a. creare, iniziare (un nuovo rapporto) } \\
\text { b. rapporto tutelato dalla legge che ha un } \\
\text { valore economico }\end{array}$ \\
$\begin{array}{l}\text { 3. regolare (un rapporto) } \\
\text { 4. estinguere (un rapporto) }\end{array}$ & $\begin{array}{l}\text { d. porre fine (ad un rapporto che esiste già) } \\
\text { 5. rapporto giuridico patrimoniale } \\
\text { e. modificare, disciplinare (un rapporto che } \\
\text { esiste già) }\end{array}$
\end{tabular}

\section{Capire}

Vero o falso? Rispondi con una X.

1. Il contratto può essere costituito da una sola parte.

2. Il contratto deve sempre avere un valore economico.

Figura 7- atividade 2, p. 47 do livro Italiano per Giuristi.

É muito importante, a nosso ver, a utilização desse exercício de compreensão lexical, pois possibilita uma melhor compreensão no momento da 


\section{leitura do texto principal. Outro recurso utilizado é a inserção de balõezinhos}

\section{explicativos no próprio texto, que facilita bastante a compreensão:}

4 Leggere

Leggi il testo ${ }^{3}$. Aiutati con le spiegazioni ai lati.

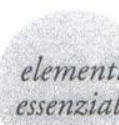

L'accordo delle parti. Il contratto) è definito dall'art. 1321 come "accordo": l'accordo delle parti è il primo dei requisiti che deve presentare per essere effettivamente un contratto, insieme con la causa, l'oggetto ed eventualmente la forma (art. 1325 $)^{4}$. Si ha un accordo quando due o più persone manifestano reciprocamente le proprie volontà, e queste sono dirette allo stesso scopo.

L'accordo si può formare attraverso una proposta, da parte di una persona e diretta a un'altra, seguita poi da un'accettazione, da parte del destinatario della proposta e diretta al proponente.

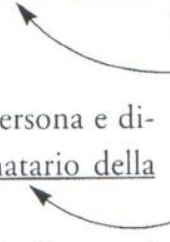

La proposta è effettivamente tale se contiene la regolazione di tutti gli aspetti $s i$ rilevanti dell'operazione economica che il contratto realizza. L'accettazione è efrealizza, fettivamente tale se è esattamente conforme alla proposta; in caso contrario essa non ha l'effetto di concludere il contratto, ma ha invece il valore di controproposta (art. 1326 c.5) .

Il contratto è concluso "nel momento (e nel luogo) in cui il proponente viene a conoscenza dell'accettazione dell'altra parte" (art. 1326 c. 1) ${ }^{6}$. Che cosa significa "viene a conoscenza"? Se la proposta e l'accettazione intercorrono fra due persone che si ritrovano l'una in presenza dell'altra (o che comunicano per telefono), il momento della conclusione è quello in cui il proponente ascolta la frase di accettazione; se invece sono lontane e comunicano per lettera, fax ecc. il momento della conclusione è quello in cui la lettera di accettazione giunge al domicilio del revocazione, proponente (art. 1335)7.

annullamento

La proposta contrattuale può essere revocata. Ecco cosa prevede il codice: Art. 1328 Revoca della proposta e della accettazione. - La proposta può essere revocata finché il contratto non sia concluso. Tuttavia, se l'accettante ne ha intrapreso in buonafede l'esecuzione prima di avere notizia della revoca, il proponente è tenuto ad indennizzarlo delle spese e delle perdite subite per l'iniziata esecuzione del contratto. L'accettazione può essere revocata,purché la revoca giunga a conoscenza del proponente prima dell'accettazione.

\section{convinzione}

di pensare o agire onestamente e

giustamente senza

causare danno

a nessuno

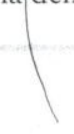

risarcirlo, pagarlo mancati guadagni danni

Figura 8- atividade 4, p. 48 do livro Italiano per Giuristi. 
Para aquisição do vocabulário, após a leitura desse texto, o livro apresenta três tipos diferentes de exercícios. O primeiro deles é de múltipla escolha, o segundo consiste na resolução de um problema envolvendo aspectos jurídicos, e o terceiro visa fixar a terminologia por meio de uma atividade lúdica conhecida como "palavras cruzadas".

Como já foi dito, essa unidade trata do instituto jurídico do "Contrato"; tal assunto é muito amplo e trabalhoso, por isso seria impossível entender toda a teoria contratual em uma única unidade. Devemos ter em mente, contudo, que o objetivo do manual é o conhecimento linguístico, isto é, se o aluno quiser se aprofundar no estudo da doutrina jurídica deverá procurar uma bibliografia mais especializada. Por tratar o assunto de forma simplificada e didática, para que 0 estudante possa entrar em contato com o léxico jurídico italiano, o autor separou o assunto em pequenos textos, com exercícios de fixação, referentes a cada tema proposto, com o objetivo de facilitar a aquisição e a compreensão da terminologia jurídica.

O segundo texto proposto (pág. 51) diz respeito ao "objeto e conteúdo do contrato", seguido de exercícios de fixação. O terceiro texto (pág. 52) aborda "a causa e o motivo", e o quarto texto (pág. 55) discorre sobre "a forma". Todos os textos tratam de elementos essenciais na formação do contrato e seguem a mesma estratégia do primeiro texto (mostrado acima), com "balõezinhos" que contêm notas explicativas do vocabulário novo e desconhecido pelos alunos. A unidade didática continua, assim, trazendo os diferentes elementos do contrato em textos explicativos e exercícios de fixação até a página 58 , em que apresenta um modelo contratual propriamente dito, conforme podemos observar na figura que segue: 
22 Verificare

Sulla base delle informazioni tratte dagli esercizi precedenti, verifica se in questo schema di contratto ${ }^{16} \mathrm{ci}$ sono tutti $i$ requisiti fondamentali richiesti dalla legge (accordo fra le parti, causa, oggetto e forma).

CONTRATTO DI COMPRAVENDITA
Con la presente scrittura privata, valevole ad ogni effetto di legge, tra
parti: - Sig. Marco Vescovi, nato a Parma il 30.8. in Via San Girolamo 8, da una parte;

parte;
- la Sig.ra Francesca Ventura, nata a $020 \mathrm{P}$
codice fiscale FRC VNT 65 M 49 L02te;

Via Roncobonoldo premesso che Fiat Punto ELX I1 Sig. Marco Vescovi è p

1.2 targata $\mathrm{AC} 047 \mathrm{NW}$ si conviene e si stipula quanto segre: Il Sig. Marco Vescovi vende alla Sig.ra Francesca Ventura che acoprietà; l'autovettura Fiat 11 prezzo del bene è fissato in ela dalla Sig.ra Francesca Ventura al Il prezzo del bene è fissato in $€ 12.500$ (dodicinich
Il suddetto importo verrà pagato dalla Sig.ra Francesca Ventura al
momento della consegna del bene. Tutte le spese del presente contratto ell'art. 1475 del c.c. del compratore a noma, il 7 dicembre 2003.

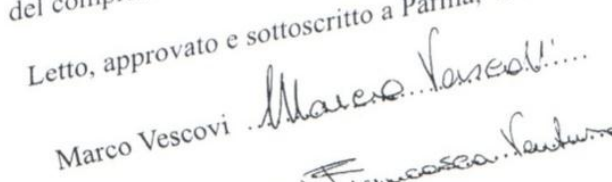

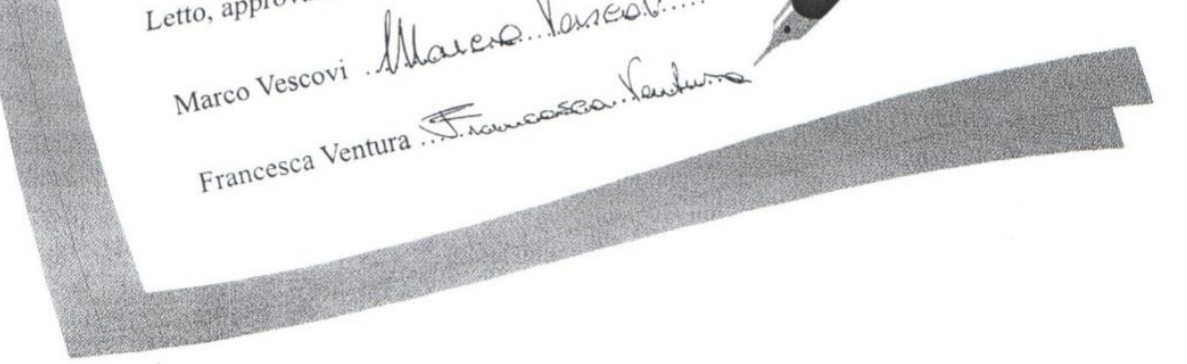

Figura 9- atividade 22, p. 58 do livro Italiano per Giuristi.

A partir desse modelo de contrato, pudemos realizar com os alunos, tanto de nível iniciante como de nível intermediário, uma atividade de produção escrita; pedimos que escrevessem um contrato simples, que tivesse todos os 
requisitos previstos em lei quanto à formação do contrato. Essa atividade foi muito produtiva, pois pudemos perceber o quanto os alunos eram capazes de produzir por escrito a partir do conhecimento que haviam adquirido até então. Discorreremos mais detalhadamente a esse respeito no momento da explanação sobre a pesquisa de campo com cada um dos grupos.

Fizemos a nossa primeira análise desse manual baseando-nos na ordem das atividades propostas, que, basicamente, são: leitura, compreensão e fixação dos termos jurídicos e alguns exercícios de gramática. Para exemplificar, fizemos uma lista das atividades (os números entre parênteses indicam o número da atividade no livro) da unidade 08: "tradurre" ( $\left.n^{\circ} 1\right)$, "comprendere la terminologia giuridica" (2 e 16), "capire" (3, 5, 9, 12, 18, 19), "leggere" $(4,8,11,17)$, "risolvere" (6), "fissare la terminologia giuridica" $(7,10$, 14, 20), "riflettere" (13), "riflettere sulla lingua - la particella ne" (15), "schematizzare", (21), "verificare" (22), "riflettere sulla lingua - L'uso del participio presente" (23).

Em síntese, podemos dizer que os objetivos do manual são a leitura e a compreensão de textos de forma muito simplificada, o que permite ao professor utilizá-lo, até mesmo, com alunos iniciantes; foi exatamente isso que fizemos. Discorreremos sobre esse uso na parte desta dissertação em que relataremos a nossa experiência com os alunos da faculdade de Direito do Largo São Francisco.

\section{3- Elogio dei giudici scritto da un avvocato}

O livro Elogio dei giudici scritto da un avvocato, de Piero Calamandrei, que conta com uma versão para o português intitulada Eles, os juízes, vistos 
por um advogado, não é um livro didático. Esse livro foi escrito por um advogado italiano em 1935 e reeditado muitas vezes; a sexta impressão é de fevereiro de 2009 e foi a partir desta que realizamos várias atividades durante as aulas. Essa obra foi sugerida pelos próprios alunos e, a partir dela, elaboramos várias atividades, que serão relatadas no decorrer da presente dissertação.

A obra de Piero Calamandrei inspira, a nosso ver, todos aqueles que se interessam em desvendar os melindres da prática judiciária e o relacionamento entre juízes, advogados e clientes. O escritor, por meio de anedotas e de considerações cheias de humor, retrata situações que envolvem não só o cotidiano de advogados e juízes, mas, principalmente, dos clientes.

Ao trabalharmos com esse livro, procuramos realizar atividades para 0 desenvolvimento das habilidades de compreensão escrita, de produção escrita e de produção oral. No que concerne à primeira, solicitamos aos alunos que fizessem, individualmente, algumas leituras do texto e que, a partir deste, elaborassem um glossário com as palavras cujos significados eles desconheciam. Quanto à segunda, propusemos que os estudantes escrevessem um resumo da obra. No tocante à terceira, por sua vez, a atividade realizada foi a seguinte: nas aulas, os discentes conversavam com os colegas sobre o texto lido.

\section{4- Espresso A1 - corso di italiano}

Como a nossa pesquisa foi elaborada em duas etapas (primeiramente, fizemos uma pesquisa com estudantes de nível intermediário e, posteriormente, com aprendizes de nível iniciante), usamos, também, um livro 
didático de nível $\mathrm{A} 1$ com o grupo de alunos iniciantes. O manual didático que escolhemos foi o Espresso 1. Publicado pela Alma Edizioni, o primeiro volume do livro totaliza noventa horas de aulas e é acompanhado por um caderno de exercícios, o qual deve ser utilizado pelos discentes fora das aulas, ou seja, eles devem usá-lo para praticar e revisar os conteúdos estudados na classe.

A edição atualizada desse livro está, segundo os autores, em consonância com os parâmetros do Quadro comum europeu de referência para as línguas, e inclui: um livro com dez unidades didáticas; dez unidades de exercícios; quatro seções de revisão; textos referentes a um "aprofundamento cultural"; materiais para a autoavaliação e um CD com textos orais, e exercícios de pronúncia.

Escolhemos esse material devido ao fato de os textos orais contidos no CD serem muito semelhantes a diálogos produzidos por falantes nativos de italiano em situações reais de comunicação. Como um dos nossos objetivos consistia no desenvolvimento da compreensão oral, pareceu-nos ser muito importante que os alunos fizessem exercícios de escuta com base em textos orais que se assemelhassem a textos autênticos. 


\section{3- PROPOSTAS DE CURSOS DE ITALIANO JURÍDICO}

\section{1- Curso de Italiano para Juristas na OAB- Jundiaí}

A proposta para o curso de italiano para juristas na Ordem dos Advogados do Brasil (OAB) de Jundiaí foi encaminhada à diretoria em 2010, quando iniciamos o nosso mestrado. O objetivo sempre foi verificar, na prática, com um grupo de alunos heterogêneos, do ponto de vista profissional, o uso dos manuais descritos nos tópicos anteriores. A nossa experiência, até então, tinha sido com alunos particulares, aos quais dávamos aulas individuais, e não com um grupo de alunos. Por esse motivo, a Ordem dos Advogados seria 0 lugar ideal para propormos o novo curso.

A proposta foi aceita pela diretoria da OAB somente em junho de 2012 e, para nós, foi muito gratificante, pois pensávamos que o curso não iria mais acontecer. A divulgação ficou a cargo da própria entidade que comunicou, por e-mail, a todos os inscritos na Ordem dos Advogados do Brasil, 33ª secção.

O programa do curso, que foi divulgado, previa a realização de dois cursos (módulos) em dois níveis diferentes. O primeiro nível era dirigido a alunos que não tinham nenhum conhecimento da língua italiana; o segundo, por sua vez, era destinado a quem tivesse conhecimentos básicos do idioma.

Como dissemos anteriormente, a aprovação do curso ocorreu somente em junho, e a divulgação dele foi feita a partir de então. O início estava previsto para o mês de julho, na primeira quinzena, no entanto, por ser um mês em que muitas pessoas viajam com os filhos por causa das férias escolares, não houve um grande número de inscritos. 
Estruturamos o curso em quatro estágios, com duração média de dois meses cada um. Cada estágio contava com a carga horária de vinte horasaula. As aulas foram organizadas de acordo com o conteúdo dos manuais: Italiano per giuristi e Una lingua in Pretura. O primeiro módulo/nível não foi realizado, pois somente duas pessoas inscreveram-se, e, para a concretização do curso, estipulamos o número mínimo de cinco alunos.

Segue, abaixo, a programação das aulas do segundo nível, pois foi o grupo que efetivamente se formou, com discentes que já tinham conhecimento básico do idioma italiano:

\begin{tabular}{|c|l|}
\hline $\begin{array}{l}\text { Aulas às quartas-feiras das } \\
\mathbf{1 9 h} \mathbf{3 0} \text { às 22h }\end{array}$ & Conteúdo programático para o 20 nível \\
\hline $13 / 07 / 12$ & $\begin{array}{l}\text { II sistema giuridico italiano (Italiano per giuristi - p. } \\
08) .\end{array}$ \\
\hline $20 / 07 / 12$ & $\begin{array}{l}\text { Scienze e rami del Diritto (Una lingua in Pretura - p. } \\
10)\end{array}$ \\
\hline $27 / 07 / 12$ & Leggere le fonti (Italiano per giuristi - p. 14) \\
\hline $03 / 08 / 12$ & La gerarchia delle fonti (Italiano per giuristi - p. 19) \\
\hline $10 / 08 / 12$ & $\begin{array}{l}\text { Diritti e doveri dei cittadini (Una lingua in Pretura - p. } \\
01)\end{array}$ \\
\hline $17 / 08 / 12$ & Diritto romano (Una lingua in Pretura - p. 39) \\
\hline $24 / 08 / 12$ & $\begin{array}{l}\text { La costituzione della Repubblica Italiana (Una lingua } \\
\text { in Pretura - p. 28). }\end{array}$ \\
\hline $31 / 08 / 12$ & $\begin{array}{l}\text { Attività extra- Testo: Le perfezioni provvisorie. } \\
\text { Gianrico Carofiglio. (Cap. 12, p. 100). }\end{array}$ \\
\hline & \\
\hline
\end{tabular}

Conseguimos formar um grupo de cinco alunos, que afirmavam possuir conhecimento básico da língua italiana. Convém ressaltar que não foi realizado nenhum teste de nível. 
Iniciamos, portanto, a nossa pesquisa de campo em julho de 2012. O grupo era composto de quatro mulheres e um homem, com idades variadas entre 33 e 56 anos. É interessante observar que a maior parte do grupo (três dos cinco alunos) possui a cidadania italiana. A tabela a seguir ilustra o perfil dos alunos:

\begin{tabular}{|r|r|r|l|c|}
\hline NOME & SEXO & IDADE & PROFISSÃO & $\begin{array}{l}\text { DUPLA } \\
\text { CIDADANIA? }\end{array}$ \\
\hline J. & M & 56 & Advogado & Não \\
\hline R. & F & 56 & Advogada & Sim \\
\hline I. & F & 53 & Procuradora Estadual & Sim \\
\hline P. & F & 41 & Advogada & Sim \\
\hline A. & F & 33 & Advogada & Não \\
\hline
\end{tabular}

Desde o início do curso, dissemos aos estudantes que o trabalho desenvolvido no decorrer das aulas seria utilizado como parte da nossa pesquisa de mestrado. Todos os discentes assinaram a autorização que nos permitiria o uso do material produzido por eles durante o curso.

Todos eles já tinham estudado o idioma anteriormente, mas não sabiam definir, com precisão, há quanto tempo. Os estudantes J. e I., por serem casados, estudaram italiano juntos e, por muito tempo, como autodidatas; depois, tiveram aulas com uma professora particular. A aluna P. é filha de italianos, e os pais levavam-na para passar férias na Itália; assim, ela aprendeu a comunicar-se no idioma, mas estuda a gramática com uma professora há menos de um ano. A aluna A. estudou essa LE por alguns anos, com uma professora particular, mas o curso era ministrado somente alguns meses por ano, pois a professora, por problemas pessoais, deixava de dar as aulas por 
um período e, depois de um ou dois meses, retomava-as. Essa discente afirmou que, durante sua vida escolar, sempre foi reprimida quando queria expressar-se oralmente, e isso fez com que ela se inibisse na hora de se expressar em italiano. A aluna R., filha de um italiano e uma suíça, falava o idioma com os pais desde pequena. Quando ela começou a frequentar a escola primária, falava italiano fluentemente, mas, segundo o seu relato, as pessoas zombavam dela na escola, e isso fez com que ela reprimisse o italiano e não o falasse mais. Esse fato a prejudica até hoje, pois, conforme ela mesma declarou, perdeu o vocabulário e sente-se muito insegura quando quer se expressar em italiano.

No início, como não sabíamos qual era o nível de compreensão dos aprendizes, começamos a trabalhar com os manuais citados (Italiano per giuristi e Una lingua in Pretura), que foram bem aceitos pelos estudantes. Com o uso de tais livros, seguíamos as recomendações indicadas pelos autores dos dois livros e procurávamos ver qual era a dificuldade dos alunos no decorrer de cada exercício.

Quando trabalhávamos com o livro Italiano per giuristi, os alunos não tinham muita dificuldade para acompanhar e realizar os exercícios, porque, conforme já dissemos, a linguagem é bem simplificada e, até mesmo, quando há algum elemento lexical novo, é apresentado de forma bastante elementar. Já nas primeiras aulas, por exemplo, os alunos apresentaram um trabalho sobre o sistema jurídico italiano. Isso nos indicou, claramente, que não tinham dificuldade para compreender o conteúdo visto durante as aulas. Ao terminarmos uma das atividades, em classe, pedimos aos alunos para 
elaborarem um esquema sobre o sistema jurídico brasileiro, atividade que deveria ser apresentada na aula posterior.

No decorrer de toda a unidade 2, procuramos avaliar continuamente os estudantes, verificando sempre as quatro habilidades: compreensão escrita, produção escrita, compreensão oral e produção oral. Ao final das atividades, os discentes compreendiam bem os textos escritos; além disso, demonstravam maior segurança ao escrever do que ao falar em italiano. A compreensão oral poderia ter sido melhor trabalhada, se a unidade contivesse exercícios de áudio; no entanto, como não os continha, restringiu-se à fala do professor. A produção oral dos alunos ainda era insuficiente, e continuamos analisando se isso se devia à falta de vocabulário, à dificuldades com a gramática ou somente à insegurança.

Já nas lições do livro Una lingua in Pretura, os alunos apresentavam bastante dificuldade, no início. No desenrolar das aulas, praticamente na metade desse estágio, os próprios alunos manifestaram o interesse de ler a versão original do livro Elogio dei giudici scritto da un avvocato, de Piero Calamandrei. Há uma tradução de tal livro para o português, e alguns discentes tiveram a oportunidade de conhecê-lo, por isso surgiu o interesse de lê-lo na língua original.

O livro Elogio dei giudici scritto da un avvocato trata, basicamente, do relacionamento que há entre advogados e juízes no desempenho das suas profissões. O texto pode ser considerado muito atual e demonstra, com grande realismo, o modo de agir dos profissionais do Direito, com um toque de humor que o autor, de maneira peculiar, soube inserir em sua obra. A escolha do livro 
foi motivada tanto pelo fato de o autor ser italiano, quanto pelo fato de ele utilizar, no texto, um vocabulário da área jurídica.

Quando iniciamos o trabalho com a leitura do livro, propusemos aos aprendizes que esse trabalho fosse feito por capítulos: na sala de aula, discutiríamos um capítulo por vez. Todos os alunos deveriam ler o capítulo inteiro, mas cada estudante falaria a respeito de uma parte escolhida por eles, previamente. O objetivo principal dessa atividade era desenvolver a produção oral dos discentes, possibilitando-Ihes a expressão de suas opiniões. Propusemos tal atividade, pois percebemos que alguns tinham dificuldade para falar em italiano.

O trabalho deveria ser desenvolvido da seguinte maneira: orientamos os alunos a efetuar, na casa deles, três leituras do texto, para que pudessem entendê-lo. A primeira leitura seria para a compreensão geral do texto, visando somente à apreensão do sentido global. Na segunda leitura, os estudantes deveriam grifar todas as palavras desconhecidas e, a seguir, efetuar a pesquisa no dicionário para que pudessem ampliar o léxico e, consequentemente, ter uma melhor compreensão textual. Por fim, fariam uma terceira leitura, para que tivessem maior familiaridade e clareza quanto ao texto e pudessem falar a respeito do assunto. Ao chegarem à sala de aula, os aprendizes deveriam falar sobre o que tinham lido, expressando a sua opinião acerca do texto.

Como dissemos, o nosso intuito inicial era a produção oral; no entanto, os alunos vinham às aulas com textos escritos sobre o que tinham lido e, em vez de falarem espontaneamente a respeito do livro, faziam uma leitura desses textos que eles tinham produzido. Quando solicitávamos aos discentes para se 
desvencilharem do papel (em que tinham escrito tais textos), pareciam sentirse inseguros e perdidos. Começamos, então, a analisar o porquê dessa reação e concluímos que o motivo da insegurança era o tipo de linguagem usada no livro. As palavras eram difíceis, e, por vezes, não se encontravam no dicionário que eles possuíam. Precisavam fazer pesquisas na internet, e isso requeria um pouco mais de tempo na elaboração do resumo que preparavam para a aula. Por ser uma obra de difícil compreensão, o trabalho que os estudantes faziam ao lê-la tornou-se uma espécie de "reescrita" do texto: os alunos procuravam entendê-lo e, por escrito, faziam paráfrases, usando um italiano mais simples e muito menos rebuscado. No decorrer dessas atividades, entendemos que desenvolvíamos as habilidades da paráfrase e do resumo que, segundo Balboni, fazem parte das habilidades integradas, colocadas no eixo receptivoprodutivo, e possibilita ao aprendiz: "saber parafrasear oralmente e por escrito e saber resumir oralmente e por escrito" (BALBONI, 2009).

Mostramos, a seguir, um trecho do livro Elogio dei giudici scritto da un avvocato e, logo abaixo, o texto produzido por uma aluna a partir desse trecho:

Si crede che basti leggere e coordinare le regole scritte nel codice di procedura civile $o$ in quello di procedura penale, per avere una immagine fedele del funzionamento pratico della giustizia.

E un'illusione: i codici regolano soltanto quello che si vede, cioè la mimica formale che, nella rappresentazione giudiziaria, si presenta alla luce del proscenio. Ma il codice ignora tutta la preparazione che si compie dietro le quinte prima che lo spettacolo cominci; e soprattutto non può regolare i procedimenti psicologici che si svolgono nel segreto delle coscienze.

Per capire come il processo veramente funzioni, non basta neanche assistere alle udienze, o legger le sentenze, o studiare le statistiche giudiziarie; i riti essenziali della giustizia sono quelli che si celebrano senza spettatori nelle camere di consiglio ove si decidono le sorti delle cause, o nei consigli giudiziari ove si decidono le sorti dei magistrati.

Da questi misteri orfici, non dalle formalità esteriori, dipende il buon funzionamento della giustizia. Anche nella procedura, come nella liturgia, esistono ceriemonie esoteriche, alle quali 
possono partecipare solo gli iniziati: noi profani, che studiamo la procedura sui codici, ne siamo all'oscuro. (CALAMANDREI, 2009, 6르 ed. p.19 e 20).

Texto produzido pela aluna:

In questo brano che io ho fatto il compedio il scrittore riporta come devono capire il funzionamento dei processi.

Questo perché non basti le regole scritte nel codice di procedura civile o nel codice di procedura penale come alcune persone credono.

Poiché le regole regolano soltanto quello che si vede e ignora tutta la preparazione che si compie dietro le quinte, aldilà di non regolare i procedimente psicologici.

II buon funzionamento della giustizia non dipende soltanto della formalità esteriori, ma dei misteri orfici.

As expressões em negrito foram marcadas pela estudante e foram colocadas em um glossário feito por ela. Todas as expressões desconhecidas pelos aprendizes foram pesquisadas e colocadas em um arquivo que eles produziram para uso pessoal. Exemplo:

compie dietro le quinte - acontece atrás dos bastidores. misteri orfici - mistérios órficos (orfismo - religião oriunda das tradições gregas e do culto a Dioniso Zagreu, a qual preconizava a ascese a fim de acelerar a libertação da alma, através de transmigrações sucessivas).

Podemos notar que, apesar de ter cometido erros gramaticais, a aluna compreendeu o conteúdo do texto; por esse motivo, conseguiu produzir e simplificar um texto escrito. No entanto, a produção oral dela ficou prejudicada, pois, por sentir-se insegura, não conseguia expressar-se. Possivelmente, se a discente estivesse com o filtro afetivo ${ }^{43}$ mais baixo, conseguiria ter um melhor desempenho ao produzir textos orais em italiano. O estudante deve estar

\footnotetext{
${ }^{43}$ A questão do filtro afetivo é um dos elementos que fazem parte da Teoria de Aquisição de Segunda Língua proposta por Krashen: [...] O autor da Teoria de Aquisição de Segunda Língua postula a existência de três categorias de variáveis afetivas que interferem no processo de aquisição de uma língua-alvo, a saber: a motivação (alunos mais motivados tendem a obter melhores êxitos nesse processo), a autoconfiança (aprendizes confiantes e com uma imagem positiva de si mesmos, em geral, obtêm melhores resultados na aquisição de uma L2) e ansiedade (a baixa ansiedade favorece o processo em questão). VIEIRA, 2012, p. 38 e 39.
} 
"aberto", sem bloqueios mentais, ansiedade ou medo para conseguir apreender um novo idioma (CILIBERTI, 2012, p. 49).

Outro caso que podemos mencionar é o de um aluno que consegue se comunicar bem oralmente, contudo seus textos escritos apresentam erros gramaticais, como podemos notar a seguir:

Dopo la morte di un vecchio avvocato, venti anni fa, i suoi eredi hanno trovato una pendana di legno sotto il suo banco. Nella pendana c'era diversi documenti sugli tutti argomenti di tanti persone: carte gelose, lettere d'amore, testamenti, documenti compromettenti e vecchie fotografie impudiche. C'era anche molti anotazioni sugli i giudici della città. Tutti le informazione erano sistematizzate in indice alfabetico, che rimandava a una pagina. (Grifo nosso)

O aluno não encontra dificuldade para compreender o conteúdo do texto, mas ao tentar fazer a sua interpretação por escrito, em relação ao uso da gramática italiana.

Concordamos com Balboni (2009) quando diz que as microlínguas, não importa o idioma, são melhor compreendidas por técnicos, com pouco conhecimento linguístico, do que por especialistas da área de Letras ou Linguistica que não possuem conhecimento técnico, pois foi exatamente o que constatamos pelo trabalho realizado com o grupo de advogados. ${ }^{44}$

Os alunos não tiveram dificuldade alguma para compreender os manuais didáticos de italiano para juristas: entenderam bem a estrutura do sistema jurídico italiano e as suas particularidades e demonstraram essa compreensão ao participarem das discussões, em português, realizadas na sala de aula; do ponto de vista técnico jurídico, expressaram-se com muita clareza. Todavia,

\footnotetext{
${ }^{44}$ No original: Le microlingue scientifico-professionali, in italiano come nelle lingue straniere, risultano in effetti assai più comprensibili a tecnici con scarsa conoscenza linguistica che a laureati in lettere o in lingue senza alcuna competenza tecnica - e, d'altro canto, anche un madrelingua colto ha difficoltà nel comprendere la microlingua di un medico, di un informatico, di un linguista. (BALBONI, 2009, p. 33).
} 
quando propusemos as mesmas discussões em italiano, os alunos pareciam sentir-se reprimidos e não conseguiam expressar-se oralmente.

Tentamos, por diversas vezes, fazer com eles a leitura de trechos menores e pedimos-Ihes que fizessem uma interpretação oral do que tinham lido, mas o resultado obtido foi, na verdade, uma paráfrase desses trechos; é o que se vê a seguir:

II Signore Calamandrei crede che per essere un buon avvocato di cassazione, Lei dovrebbe argomentare di maneira chiara e sucinta, cercando la comprensione di tutte le persone.

Calamandrei parla che se fosse istituitore/fondatore di una scuola di oratoria forense, la farebbe funzionare così: darebbe all'allievo un fascicolo di una complicata e difficile controversia civile per studiare in una mattinata. Nell inesorabile giro di un'ora Lui oralmente dovrebbe riferire in modo chiaro e compiuto sulla controversia. II giorno seguente diminuire in mezz'ora suo discorso e il terzo giorno ridurre a un quarto d'ora, nella presenza di uditorio per dimostrare che è capace di farsi intendere. (Trecho escrito por uma aluna, referente às p.76 e 77).

Podemos observar que o conteúdo do texto produzido pela aluna (obviamente, desconsiderando os erros de gramática), diz respeito à importância da oralidade na vida profissional de um advogado. Este, no exercício de sua função, deve saber falar de modo claro, para que não haja controvérsia em seu discurso. Assim sendo, como esses aprendizes, que são profissionais da área de Direito e têm facilidade para expressarem-se (oralmente e por escrito) em português, apresentam tanta dificuldade para falar italiano? Tendo em vista essa questão, acreditamos que o mais importante seria encontrar o meio adequado para favorecer o desenvolvimento da produção oral de nossos alunos. Mas qual a melhor maneira de alcançar esse objetivo?

Para buscar possíveis maneiras de atingi-lo, foi-nos necessário refletir muito acerca de nossa própria prática didático-pedagógica e das dificuldades 
de nossos discentes. Segundo Kumaravadivelu (2003), a condição pós-método permite que o professor construa teorias a partir da própria prática, criando estratégias de ensino. Com essa autonomia para lecionar, passamos a desenvolver a autocrítica, avaliando o nosso modo de ensinar, construindo e reconstruindo novas formas de trabalhar com os alunos durante as aulas.

Além disso, temos plena consciência de que, apesar da divisão clássica entre a escrita e a fala, as duas modalidades misturam-se e é difícil traçar uma linha de separação entre elas (MONDAVIO, 2013).

Assim sendo, partindo da análise de nossa própria prática, mas avaliando também as dificuldades desses alunos, começamos um lento percurso para desenvolver a produção oral.

O primeiro passo foi dar continuidade ao trabalho já mencionado; no entanto, solicitamos aos discentes que expusessem, oralmente, o que compreenderam do texto lido, mesmo que eles tivessem feito, por escrito, um resumo deste; isto é, pedimos que os aprendizes não lessem o que tinham escrito, mas sim que dissessem, com suas próprias palavras, o que apreenderam da leitura. No início, eles tiveram muita dificuldade em atender a nossa solicitação. Nas primeiras aulas, propusemos que os estudantes falassem, em português, a respeito do texto. Por isso, eles mostraram-se bastante seguros e expuseram, com clareza, as expressões que tinham pesquisado.

A partir da explicação, em português, pedíamos para que tentassem falar, mesmo que com poucas palavras, em italiano. Mas, ao fazermos tal proposta, a atitude de alguns alunos mudava, como se quisessem fugir da sala de aula. Não conseguíamos entender o motivo desse comportamento, mas, 
para que se sentissem mais tranquilos, permitíamos-Ihes que lessem o texto que eles tinham escrito em casa, em italiano. Contudo, esclarecemos aos aprendizes que, na aula seguinte, eles deveriam tentar falar em italiano, em vez de ler, em voz alta, o texto escrito. Com essa dificuldade, terminamos o segundo estágio e, baseando-nos nela, definimos que, no estágio seguinte, nosso objetivo consistiria no desenvolvimento da produção oral dos discentes.

O terceiro estágio foi proposto para os meses de outubro e novembro, e decidimos usar somente um dos manuais: Italiano per giuristi. Fizemos essa escolha, pois as atividades de tal livro são mais simples do que as de Una lingua in pretura, o que poderia fazer com que os alunos se sentissem mais seguros ao realizá-las. Trabalhando com um único livro didático, planejamos as aulas com um tempo maior reservado à produção oral. As atividades que visavam ao desenvolvimento dessa habilidade foram propostas, sobretudo, a partir da leitura do livro Elogio dei giudici. A seguir, mostramos a programação do terceiro estágio:

\begin{tabular}{|c|l|}
\hline Aulas das 19h30 às 22h & Conteúdo programático para o 3 estágio \\
\hline $10 / 10 / 12$ & Diritto Costituzionale - Le leggi ordinarie (p. 23) \\
\hline $17 / 10 / 12$ & Diritto Costituzionale - I decreti-legge (p. 30). \\
\hline $24 / 10 / 12$ & Diritto Costituzionale - I decreti leggislativi (p. 30). \\
\hline $07 / 11 / 12$ & $\begin{array}{l}\text { Comparazione fra sistemi: civil law e common law (p. } \\
41)\end{array}$ \\
\hline $14 / 11 / 12$ & Diritto Civile - La struttura del contratto (p. 47) \\
\hline $21 / 11 / 12$ & Diritto Civile - Le obbligazioni (p. 60). \\
\hline $28 / 11 / 12$ & $\begin{array}{l}\text { Diritto Civile - Proprietà, detenzione, possesso e } \\
\text { usucapione (p. 66) }\end{array}$ \\
\hline $05 / 12 / 12$ & $\begin{array}{l}\text { Diritto Commerciale - Impresa, ditta, azienda... (p. } \\
75) .\end{array}$ \\
\hline
\end{tabular}


Na aula do dia 14 de novembro, trabalhamos a unidade 08 , que aborda a estrutura do contrato. Como já dissemos anteriormente, quando tratamos do instituto jurídico do contrato, uma única aula é pouco para analisarmos todos os aspectos estruturais da formação contratual. No entanto, procuramos trabalhar de forma simplificada todas as partes importantes, para que os alunos conseguissem se apropriar tanto do léxico em italiano quanto da estrutura desse gênero textual.

Para exercitarmos o que haviam aprendido, propusemos que fizessem um pequeno contrato, como tarefa de casa, e trouxessem para entregar na aula seguinte. Os alunos tinham visto, durante a aula, que os requisitos para a formação do contrato são: o acordo entre as partes, a causa (ou motivo), o objeto e a forma. Explicando de modo bem simplificado podemos dizer que: 0 acordo entre as partes significa que as partes contratantes (contratante e contratado) devem estar de acordo com todos os aspectos relativos ao contrato. A causa, ou o motivo é o "porquê" do contrato, por exemplo a compra e venda de um carro, ou de uma casa. Já o objeto é o conteúdo (por exemplo, qual o valor do bem, como será pago etc.), que deve ser relacionado a um bem patrimonial com as características previstas em lei. E, por fim, a forma, ou seja, o modo como é feito o contrato, deve, também, seguir a previsão da lei. Todo aluno de Direito (que já estudou essa matéria na faculdade) conhece os detalhes sobre a formação do contrato brasileiro, que são, basicamente, os mesmos no direito italiano. A seguir, mostramos o contrato elaborado por um dos alunos: 


\section{CONTRATTO DI COMPRAVENDITA}

Con la presente scrittura privata, valevole ad ogni effetto di legge, tra le parti:

TIZIO BERLUSCONI, italiano, sposato, contadino, con Carta d'Identità n. ${ }^{\circ}$ Codice Fiscale n. ${ }^{\circ}$ e residente in Via Pisa, n. ${ }^{\circ}$ 02, Bologna, Itália, ora chiamato di venditore, e CAIO FORMIGONE, italiano, celibe, avvocato, con Carta d'Identità n. ${ }^{\circ} \ldots \ldots \ldots \ldots . . . . .$, Codice Fiscale n. ${ }^{\circ}$ e residente in Via Veneto, n. ${ }^{\circ}$ 35, Treviso, Itália, ora chiamato dell'acquirente, accordano il seguinte negozio giuridico:

II Signore Berlusconi, nella qualità di proprietário dell'automobile Ferrari di tipo EX 5.7, di colore nero, anno 2012/2012, targata ......... fà la proposta di vendita al Signore Formigone, che la accetta con le seguenti condizioni:

Il prezo del bene è fissato fra le parti in $€ 1.000 .000,00$ (um milione di Euro), il quale sarà pagato con assegno in momento della firma di questo contratto.

La firma e la consegna sarà nella rezidenza del Signore Berlusconi.

Letto, appprovato e sottoscritto a Bologna, il 31 ottobre 2012.

Firma del venditore

Firma dell'acquirente 
Como mencionamos, os alunos tinham por hábito produzir glossários sobre os termos novos que viam durante as aulas; abaixo, reportamos dois glossários que foram elaborados a partir da aula sobre Direito dos Contratos:

\section{GLOSSARIO DEI TERMINI DEI CONTRATTI}

Contratto di compravendita: Contrato de Venda e Compra

Promittente Acquirente: Promitente Comprador

Promittente Venditore / promittente vendetrice: Promitente Vendedor (a)

Scrittura privata: Escritura Privada (instrumento particular)

Effetti di leggi: efeitos das leis

Accordo: acordo

Convengono e stipulano: convencionam e estipulam

Consegnare: entregar

Accettata (accettare): aceitar

Fissi ed infissi: firme e acabado

Reditto: renda, ganho

Sottoscritto: abaixo assinado

Caparra: sinal, penhor

A Carico di: a cargo de

Glossário 01- Contrato em geral 


\section{Glossário}

(Contratto di compravendita)

- PROMITTENTE VENDITORE: promitente vendedor;

- REGIME PATRIMONIALE: regime patrimonial de bens, como a comunhão parcial de bens, universal, etc.;

- PARTE VENDITRICE: parte vendedora;

- PROMITENTE ACQUIRENTE: promitente comprador;

- PARTE ACQUIRENTE: parte adquirente;

- EFFETTO DI LEGGE: sob os efeitos da lei;

- SI CONVIENE E STIPULA QUANTO SEGUE: convencionam e estipulam quanto segue;

- UNITÀ IMOBILIARE SITA IN LOCALITÀ: unidade imobiliária situada na localidade;

- CATASTO: cadastro imobiliário;

- PARTICELLE: fração, unidade cadastral;

- CAPARRA PENITENZIALE: multa;

- DIRITTI REALI: direitos reais;

- CERTIFICATO DI AGIBILITÀ: habite-se;

- DICHIARAZIONI DEI REDDITI: declaração de renda;

- VINCOLO PREGIUDIZIEVOLE: vínculo prejudicial, danoso, nocivo;

- CESPITE: fonte de renda, bens.

Glossário 2- Contrato de compra e venda

A unidade sobre os contratos foi uma das mais interessantes do manual, por esse motivo a escolhemos para ilustrar o trabalho que realizamos com os aprendizes; este foi muito produtivo, e os alunos participaram com muito empenho de cada atividade proposta. Tivemos um resultado muito positivo, pois eles escreveram com bastante desenvoltura e não tiveram nenhuma dificuldade na elaboração do contrato. Acreditamos que isso tenha acontecido 
porque o assunto é muito similar no direito brasileiro, e isso fez com que os alunos se sentissem mais confiantes no momento da produção escrita.

Como atividade complementar, usávamos os textos do livro Elogio dei giudici scritto da un avvocato e, nesse terceiro estágio, procuramos trabalhar com mais profundidade o léxico. Para tanto, propusemos que os estudantes pesquisassem as expressões ou palavras que não conheciam e formulassem glossários a partir de cada texto estudado e lido. Alguns alunos "esqueciam-se" de colocar, ao final de cada resumo, o glossário. Mas, isso não significava que não tinham pesquisado as palavras/expressões vistas durante a leitura. Transcrevemos, abaixo, alguns resumos produzidos pelos aprendizes a partir dos textos lidos:

Resumo 1- Elogio dei Giudici, p. 19 a 21

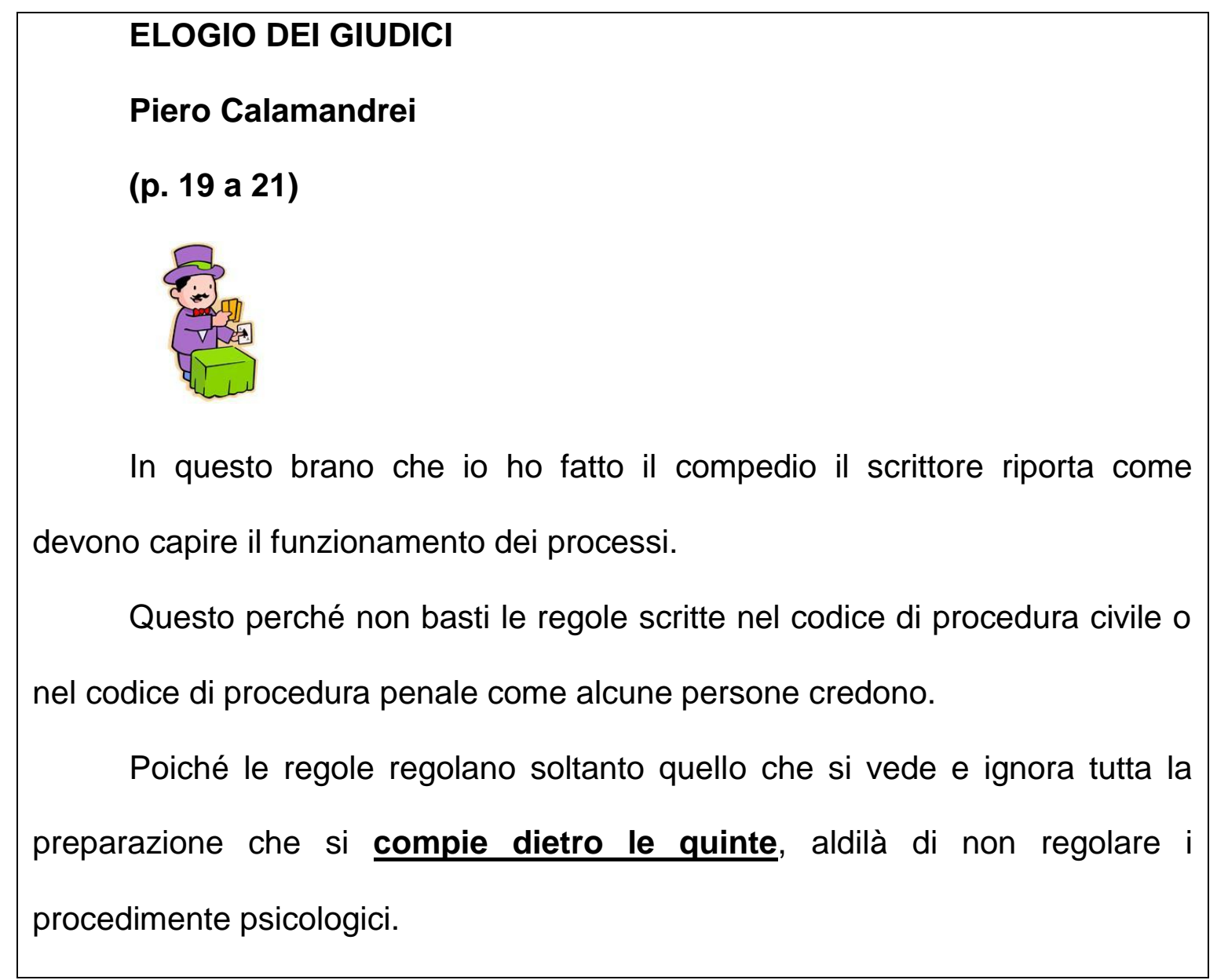




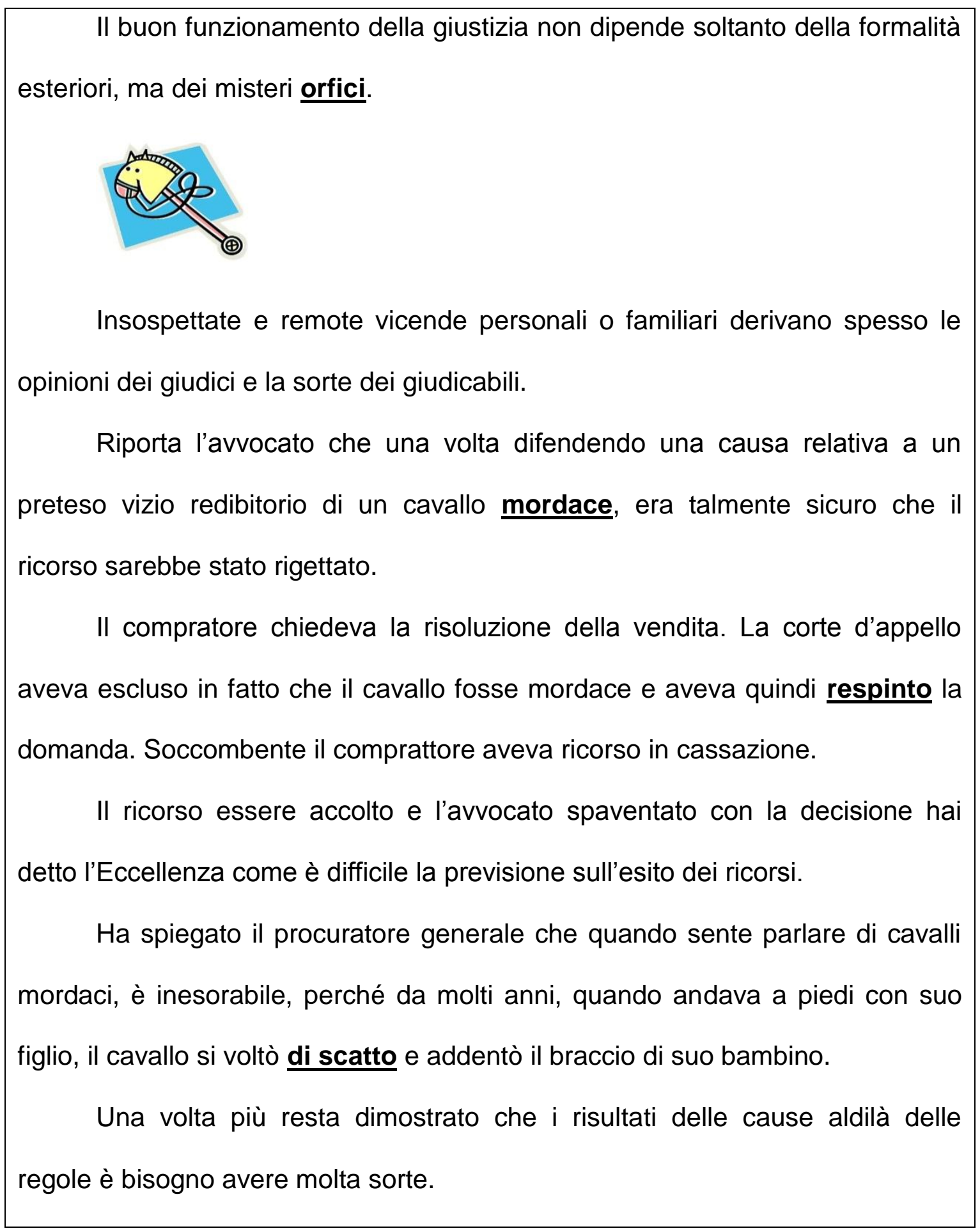

Glossário 3- Resumo 1- Elogio dei Giudici, p. 19 a 21

compie dietro le quinte - acontece atrás dos bastidores. 
misteri orfici - mistérios órficos (orfismo - religião oriunda das tradições gregas e do culto à Dioniso Zagreu, a qual preconizava a ascese a fim de acelerar a libertação da alma, através de transmigrações sucessivas).

mordace - que morde.

respinto - rejeitou, rechaçou.

di scatto - de repente.

Resumo 2- Elogio dei Giudici, p. 22 a 25

\section{ELOGIO DEI GIUDICI}

Piero Calamandrei

(P. 22, 23, 24 e 25)

Calamandrei racconta uma storia di uno cliente suo per dimostrare l'incertezza della decisione giudiziale, che puó dipendere dai tanti imponderabili elementi.

Racconta que il cliente, un benestante meridionale, che aveva vinto la causa in corte d'apello e gli aveva cercato per difenderlo nella Corte di Cassazione. Dopo leggere la sentenza, il recorso, Calamandrei si rifiuta di accetare la difesa, convinto que la causa era perduta.

Dopo più di um anno, alla vigília della discussione, il cliente gli ha cercato una volta più per fare l'udienza in Tribunale. Per insistenza del cliente ha acettato fare l'udienza, anziché convinto di essere una causa perduta.

In udienza I avoccatto dell'altro era bravo, um avversario temibilissimo, ma stranamente aveva fatto una diffesa disastrosa.

Perplesso, Calandrei ebbe buon giocco, nell'improvisare una confutazione che convince gli ascoltatori. 


Il procuratore generale fu convinto e chiese che il ricorso fossi rigettato.
La Corte alla fine ha rigettato il ricorso.
Habent sua sidera lites...La mattina dopo, viene al suo studio il cliente,
ancora eccitato per il trionfo, a ringraziarlo della bella vittoria.
A questo momento il cliente gli parlò che ieri matina, prima dell'udienza
era stato per due ore in chiesa a pregare il suo santo protettore perché
togliesse la parola all'avvocato avversario e il suo santo gli ha fatto la grazia..
Calamandrei fa una postilla.
Racconta questa storia in una conferenza sul tema L'AVVOCATO E I
CLIENTI e senza volere aveva detto il nome di una città.
Alla fine della conferenza, mentre era attorniato da un cerchio de gentili
regione e la religione.
Lamici venuti a salutarvi, si aprì il passo fino a lui una giovine signora moto
risoluta, che lanciando fiamme dagli occhi, gli dice que lui abbia vilepeso sua

Resumo 3- Elogio dei Giudici, p. 25 a 28

\begin{tabular}{|c|}
\hline ELOGIO DEI GIUDICI \\
Piero Calamandrei \\
(P. 25, 26, 27 e 28) \\
Dopo la morte di un vecchio avvocato, venti anni fa, i suoi eredi hanno \\
trovato una pendana di legno sotto il suo banco. Nella pendana c'era diversi \\
documenti sugli tutti argomenti di tanti persone: carte gelose, lettere d'amore,
\end{tabular}


testamenti, documenti compromettenti e vecchie fotografie impudiche. C'era anche molti anotazioni sugli i giudici della città. Tutti le informazione erano sistematizzate in indice alfabetico, che rimandava a una pagina.

Ogni pagina conteneva una specie di scheda biografica. Questa scheda c'era nome, cognome e tutte altre informazione personale: figli, moglie, barbiere, sarto, nome della donna di servizio, scuola dei figli, i loro professori, si era religioso (e il suo confessore), malattie, si é appassionato del giocco, degli scacchi o del calzio, giornale che leggi, libri, dove va in villeggiatura, i suoi amici, i suoi compaesani, si ha um fratello deputato o un cugino vescovo.

Un lavoro diligentissimo sulla coppertina se legeva un curioso titolo "Le vie".

Calamandrei vuol dire che c'é avvocato che lavora in questo senso, ma che assolutamente non è la migliore condotta.

Questo avvocato invece di studiare la causa sá che bisogna studiare gli uomini che devono diciderla; invece de cercare la soluzione nei codici, bisogna cercare nei giudici, analizzandoli ad uno ad uno, nella loro vita.

Calamandrei non crede che per farsi dare raggioni dal giudice non ci sia altro da fare che rispettare le regole della procedura. Di questo dici que i suoi clienti sono avvertiti e se ne trova bene.

Conclude che essi preferiscono prestazioni d'altra natura che non cerchino un'avvocato: è meglio che cerchino un venditore di fumo.

Colocamos, nesta parte de nossa dissertação, somente os textos produzidos por três alunos, pois acreditamos que sejam suficientes para ilustrar o trabalho que eles faziam fora das aulas. Podemos perceber que, nessas 
produções escritas, há falhas gramaticais, mas levamos em consideração a compreensão do conteúdo pelos discentes. Em tal fase do trabalho, o mais importante, a nosso ver, era a compreensão, porque, a partir dela, poderíamos propor-Ihes que fizessem uma explanação, mesmo que breve, oralmente. Concluímos o terceiro estágio do curso, e os estudantes ainda faziam a leitura do resumo em italiano e discutiam, em português, sobre o que tinham lido.

No quarto estágio, tivemos alguns problemas quanto ao uso da sala na sede da OAB Jundiaí, pois houve a transição de uma diretoria para outra, e a nova diretoria precisava autorizar a continuidade do curso, o que levou mais de dois meses. Tínhamos planejado iniciar o quarto estágio em 15 de janeiro de 2013 e terminá-lo por volta do final do mês de março, no entanto, não foi possível. Os alunos estavam ansiosos para retornar ao curso e, assim, decidimos continuar as aulas em outro lugar até que fosse liberado o uso da sala na sede da OAB. Recomeçamos as aulas, então, no dia 06 de fevereiro de 2013. Nesse estágio, voltamos a utilizar, durante as aulas, algumas unidades do livro Una lingua in Pretura. O planejamento do quarto estágio ficou da seguinte maneira:

\begin{tabular}{|c|l|}
\hline Aulas das 19h às 22h & Conteúdo programático para o 40 estágio \\
\hline $06 / 02 / 13$ & $\begin{array}{l}\text { Diritto Commerciale: La s.n.c. (p. 80). Italiano per } \\
\text { giuristi }\end{array}$ \\
\hline $13 / 02 / 13$ & $\begin{array}{l}\text { Diritto Commerciale: La s.a.s. (p. 85). Italiano per } \\
\text { giuristi }\end{array}$ \\
\hline $20 / 02 / 13$ & II processo in Italia (p.91). Italiano per giuristi \\
\hline $27 / 02 / 13$ & II processo penale (p. 104). Italiano per giuristi \\
\hline $06 / 03 / 13$ & Filosofia del Diritto (p. 62). Una lingua in Pretura \\
\hline $13 / 03 / 13$ & Diritto Privato (p. 71). Una lingua in Pretura \\
\hline
\end{tabular}




\begin{tabular}{|c|l|}
\hline $20 / 03 / 13$ & Não houve aula \\
\hline $\begin{array}{c}\text { Voltamos à sala da OAB } \\
03 / 04 / 13\end{array}$ & Diritto pubblico 1 (p. 81). Una lingua in Pretura \\
\hline $10 / 04 / 13$ & Diritto Penale (p. 93). Una lingua in Pretura \\
\hline $17 / 04 / 13$ & Diritto pubblico 2 (p. 104). Una lingua in Pretura \\
\hline $24 / 04 / 13$ & Diritto del lavoro (p. 115). Una lingua in Pretura \\
\hline $01 / 05 / 13$ & Valutazione \\
\hline & Chiusura del corso \\
\hline
\end{tabular}

É interessante observar que, no decorrer do último estágio, os alunos sentiam-se mais seguros, porém, nas primeiras aulas desse estágio, ainda se limitavam à leitura do resumo escrito. Na segunda aula, explicamos-Ihes que o objetivo dessa parte do curso era que eles produzissem uma explanação oral do trabalho realizado fora das aulas e insistimos para que, aos poucos, começassem a falar em italiano.

Na aula do dia 03 de abril, ficamos surpresos, pois todos os aprendizes expressaram-se bem e conseguiram explicar sobre o texto, oralmente, sem ler. Eram produções pequenas, a partir de trechos curtos do livro. Tendo em vista esse progresso, pareceu-nos que, até o término do curso, teríamos o resultado esperado.

Nas aulas seguintes, continuamos a trabalhar com o livro de Calamandrei, seguindo as instruções iniciais, ou seja, em casa, cada aluno deveria ler o texto escolhido por ele, e, na primeira leitura, ter como objetivo a compreensão global, devendo gifrar sempre as palavras desconhecidas. Em seguida, deveriam pesquisar no dicionário tais palavras, e, posteriormente, fazer uma nova leitura. Após o término desta, cada estudante deveria fazer um resumo com suas próprias palavras sobre o texto lido. 
Durante a aula, além de entregar o trabalho feito em casa, o aluno deveria contar com as próprias palavras, sem ler, o que havia compreendido a respeito do texto.

Percebemos que, gradativamente, conseguiam desenvolver a produção oral e ao término do curso, em 24 de abril, quando fizemos a avaliação, notamos um evidente progresso. Já conseguiam expor o que haviam lido e também expor a própria opinião sobre o texto que tinha sido estudado. Fizemos a filmagem dessas apresentações, para a seguir analisarmos com mais cuidado, e pudemos perceber a evolução de cada aluno.

Naturalmente, fizemos uma pesquisa a respeito da opinião dos alunos quanto ao que foi visto durante o curso. Para recolher essas opiniões, elaboramos um questionário e, abaixo, transcrevemos as respostas. As perguntas são numeradas de 01 a 10, e cada aluno está identificado por uma letra.

\section{QUESTIONÁRIO DE AVALIAÇÃO \\ CURSO ITALIANO PER GIURISTI- OAB JUNDIAÍ}

1) As suas expectativas iniciais a respeito do curso de Italiano para Juristas foram alcançadas?

A- "Desde que me inscrevi no curso de italiano para juristas minha pretensão era se relacionar com outras pessoas que soubessem a língua italiana, para que assim eu pudesse aprender mais. Além disso foi muito bom aprender também um pouco do Direito Italiano e suas expressões".

I- "Sim, foram plenamente alcançadas". 
J- "Sim, foram alcançadas".

P- "Sim, tendo em vista que o meu objetivo foi alcançado em aprimorar conhecimento jurídico e linguagem específica".

R- "Sim".

\section{2) Qual a sua opinião sobre o livro Italiano per giuristi?}

A- Italiano per Giuristi é um livro de fácil linguagem que propicia um aprendizado rápido, ideal para um primeiro contato com a matéria".

I- "É um bom livro, importante para aqueles, que como eu, tem o primeiro contato com o italiano jurídico. Mas não gostei dos modelos de exercício que não me prenderam a atenção".

J- "É um livro bem elaborado, mas creio que as atividades deveriam ser mais objetivas".

P- "Achei o livro bom, com exercícios bons".

R- "Foi bem produtivo como uma primeira base".

3) Quais suas impressões a respeito do livro Una lingua in Pretura?

A- "O livro Una lingua in Pretura já é um livro mais didático, que se aprofunda mais na linguagem do Direito. Alguns textos são bem difíceis de compreender em uma primeira leitura. Seria interessante que tivéssemos ouvidos todos os textos do "ascolto" para sentir a pronuncia das palavras por uma terceira pessoa".

I- "É mais interessante que o Italiano per Giuristi. Tanto os textos, quanto os exercícios me pareceram mais profundos. Alguns por sinal eram bem difíceis".

J- "É um livro mais profundo que o anterior que atingiu melhor o objetivo do curso ao desenvolver de forma mais adequada o italiano para juristas". 
P- "Achei o nível dos exercícios superior e mais complexos em relação ao livro Italiano per Giuristi. Gostei mais de estudar por ele".

R- "Muito confuso, sem qualquer nexo. Muitas vezes era inconclusivo no que deveria responder".

\section{4) Qual a atividade mais interessante que foi desenvolvida no curso?}

A- "Na minha opinião a atividade mais interessante foram as leituras do livro Elogio dei Giudici, de Piero Calamandrei”.

I- "Sem dúvida alguma o mais interessante foi a leitura, tradução e interpretação do livro "Elogio dei giudici", de Piero Calamandrei".

J- "A atividade mais interessante foi a leitura e estudo do livro Elogio dei Giudici de Piero Calamandrei".

P- "A leitura do livro/capítulo do Calamandrei e a elaboração de resumos".

R- "Todas".

\section{5) Qual a atividade que você considera menos interessante do curso?}

A- "As atividades menos interessantes são as avaliações. Na realidade não existem atividades menos interessantes, pois na realidade todas contribuem para o aprendizado".

I- "Os exercícios do livro Italiano per giuristi porque não consigo me concentrar e me interessar por aqueles modelos de exercício, talvez porque a vida inteira eu tenha sido treinada a aprender de outra maneira".

J- "As atividades do livro Italiano per Giuristi".

P- "Nenhuma. Todas as atividades foram importantes para o curso".

R- "É o resumo do livro. Sou muito detalhista". 
6) Você acredita que foi importante trabalhar com a compreensão dos textos do livro Elogio dei giudici de Piero Calamandrei? Justifique sua resposta.

A- "Sim, acredito que trabalhar com a compreensão dos textos do livro de Piero Calamandrei foi importante, pois tivemos que ler, resumir e acima de tudo extrair o pensamento principal dos respectivos trechos. É uma atividade prazerosa e que contribui para o aprendizado".

I- “Estudar Calamandrei foi importantíssimo. O livro se destina aos advogados e sua leitura nos ensina muito, ainda hoje, como se comportar e como se safar das armadilhas que são colocadas no caminho da advocacia. Por incrível que pareça, os temas ali tratados são atualíssimos e levam a uma profunda reflexão a respeito da nossa função. É um livro que deve estar na cabeceira de todo advogado. Além disso, Calamandrei tem uma fina ironia que torna a leitura muito prazerosa. Sua linguagem é refinada o que levou ao enriquecimento do vocabulário em italiano".

J- "Sim, porque as situações jurídicas apresentadas por Calamandrei, apesar de antigas e ocorridas na Itália, se aplicam plenamente ao Brasil e às atividades do advogado de hoje".

P- "Importantíssimo, desta forma houve a ampliação do conhecimento de vocábulos com a elaboração de um "Glossário", bem como o desenvolvimento da parte oral/conversação".

R- "Sim. Porque apesar das décadas passadas, é sempre atual".

7) Como você avalia o seu desempenho no curso e o que você acredita que tenha contribuído na sua formação profissional e pessoal? 
A- "Por ter sido o curso ministrado para um grupo pequeno de pessoas, isso proporcionou uma maior interação dos alunos e acredito que o meu desempenho foi melhor do que se estivéssemos em um grupo maior, pois todos tivemos a possibilidade de participar, interagir mais, o que contribui para um melhor desenvolvimento profissional e pessoal".

I- "Acredito que meu desempenho tenha sido bom. O aprimoramento do conhecimento da língua italiana, como de qualquer outra língua, representa, por si só, um acréscimo na minha formação profissional e pessoal”.

J- "O desempenho foi bom e o aprendizado de qualquer língua estrangeira sempre é importante profissionalmente e também na vida pessoal".

P. "Acredito que o meu desempenho foi bom principalmente no desenvolvimento da escrita".

R- "Boa".

\section{8) Quais os pontos positivos e os pontos negativos do curso?}

A- "Ao meu ver não existiram pontos negativos. Quantos os pontos positivos acredito que foi a possibilidade que todos os alunos tiveram de participar nas aulas de maneira igualitária, com bastante leitura e conversação".

I- "Só houve pontos positivos. O único ponto negativo, talvez, tenha sido a dificuldade em dar continuidade ao curso, no início de 2013, nas dependências da OAB. Foi uma pena. Tivemos que nos deslocar para outro local, com grande perda de tempo".

J- "Não há pontos negativos. O ponto adverso foi o deslocamento da sede da OAB para uma sala privada, por circunstâncias administrativas da própria OAB".

P. "O mais importante foi a conversação com os colegas no idioma".

R- "Não vejo ponto negativo, tudo foi um aprendizado". 


\section{9) 0 que contribuiu mais para o desenvolvimento e aproveitamento do curso? A didática da professora, os livros adotados ou a sua própria dedicação pessoal?}

A- "Tanto a didática da professora quanto os livros adotados eu classifico como ótimos".

I- "O mais importante foi a dedicação e o esforço da professora, que acreditou na capacidade de seus alunos e nos levou a avançar muito além do esperado. Soube extrair o que havia de melhor de cada um dos livros adotados e de cada um dos alunos".

J- "Contribuíram para o sucesso do curso a didática e a dedicação da professora e a escolha dos livros".

P- "A didática da professora foi ótima, principalmente pelos livros adotados".

R- "Tudo isso".

10) Deixe suas críticas ou sugestões:

A- "Como sugestão poderíamos ter um curso de língua italiana, para ver se assim aprendo os verbos".

I- "O curso poderia ser mais longo, de forma que houvesse tempo para leitura e discussão do próprio direito italiano: textos legislativos, doutrina etc.".

J- "O curso poderia ter mais tempo. Poderia iniciar com introdução com a Constituição Italiana e seus conceitos fundamentais com breve paralelo à Constituição Brasileira. A seguir, estudo geral de outros ramos do direito, organização judiciária e procedimentos gerais".

P. "Precisa de maior divulgação do curso. Eu só recebi e-mail de divulgação do 
curso no terceiro módulo".

R- "Nenhuma".

Tendo em vista as respostas dos alunos, é possível afirmar que o curso foi bastante produtivo, mas que deveria ter uma carga horária maior para que eles pudessem compreender melhor alguns conteúdos gramaticais e produzir oralmente com mais naturalidade.

\section{2- Curso de Italiano para Juristas na Faculdade de Direito da Universidade de São Paulo}

O curso de italiano para juristas na Faculdade de Direito São Francisco visava à aquisição da língua italiana voltada para o Direito. A proposta do curso foi dirigida à Comissão de Cultura e Extensão da Faculdade de Filosofia, Letras e Ciências Humanas e à Comissão de Cultura e Extensão da Faculdade de Direito. Como o curso era destinado aos estudantes da graduação e da pósgraduação em Direito, as aulas foram ministradas na própria São Francisco.

O curso foi estruturado em dois módulos: no primeiro, os discentes teriam contato com a estrutura básica da língua italiana, trabalhando a compreensão oral, a conversação, a leitura e a escrita dentro do contexto em que eles estão inseridos, ou seja, a linguagem utilizada em doutrinas, leis e textos jurídicos.

A partir do segundo módulo, os alunos entrariam em contato com a estrutura do Direito Italiano, por meio de textos simples e adaptados, para que tivessem uma aquisição/ aprendizagem gradativa da língua e do vocabulário 
específico do âmbito jurídico. O objetivo final seria alcançar um domínio básico do idioma, trabalhando as quatro habilidades e adquirindo/ aprendendo a língua específica do Direito.

Como foi um curso experimental, as inscrições eram gratuitas, e o número de vagas ficou restrito a trinta estudantes por turma. Fizemos um planejamento para dois semestres: o primeiro módulo seria de 36 horas, com início em abril e término no fim de junho de 2013; o segundo módulo teria uma carga horária de 48 horas com início em agosto e término no mês de novembro de 2013. As aulas tinham três horas de duração. Um grupo tinha aulas às segundas-feiras das $14 \mathrm{~h}$ às $17 \mathrm{~h}$, e o outro grupo, no sábado das $10 \mathrm{~h}$ às $13 \mathrm{~h}$.

A seguir, mostramos a programação inicial do curso, a qual, obviamente, poderia ser alterada em função das especificidades de cada grupo.

\section{Curso de italiano para juristas}

Dias: aos sábados ou às segundas-feiras.

Carga Horária: 1ํMódulo com carga horária total de 36 horas/aula. 2ํㅡódulo com carga horária total de 48 horas/aula

Início e término: Início do 1ำ módulo em 06 de abril e término em 22 de junho de 2013. O 2ํㅡódulo terá início em 05 de agosto e término em 13 de novembro 2013.

Dias de aulas do curso de sábado (horário das 10 às 13h):

Abril $(06,13,20,27)$, Maio $(04,11,18,25)$, Junho $(01,08,15,22)$.

Agosto $(03,10,17,24,31)$, Setembro $(14,21,28)$, Outubro $(05,19,26)$, Novembro $(09,16,23,30)$

Dias de aulas do curso de segundas-feiras (horário das 14 às 17h)

Abril $(01,08,15,22,29)$, Maio $(06,13,20,27)$, Junho $(03,10,17,24)$.

Agosto $(05,12,19,26)$, Setembro $(02,09,16,23)$, Outubro $(07,14,21,28)$, 
Novembro $(04,11,18,25)$.

\section{Bibliografia Básica:}

FORAPANI, D. Italiano per giuristi, Alma, 2003

PALMIERI, G. Dizionario dei termini giuridici. Milano, BUR Dizionari, 2006.

SEMPLICI, S. Una Lingua in Pretura, il linguaggio del diritto. Università per Stranieri di Siena- Bonacci editore, 1996.

ZIGLIO, L.; RIZZO, G. Espresso I- Corso di italiano, livello A1. Alma Edizione, Firenze, 2011.

. Espresso I- Corso di italiano, livello A2. Alma Edizione, Firenze, 2011.

\section{CONTEÚDO PROGRAMÁTICO}

1ํo Módulo

\section{1' aula}

Apresentação dos alunos, da professora e do conteúdo programático do curso.

Apresentação da bibliografia.

Comunicação: Como apresentar-se em italiano, (dizer o nome, nacionalidade e a profissão). Saudações (formal e informal).

Gramática: verbo essere e chiamarsi; singular e plural dos substantivos.

Léxico específico: "O sistema jurídico italiano". Leitura e compreensão do léxico jurídico.

\section{$2^{\mathrm{a}}$ aula}

Comunicação: Falar sobre o estado de saúde; pedir e fornecer informações pessoais; informar-se sobre conhecimentos linguísticos; desculpar-se; agradecer.

Gramática: Verbos regulares em are e alguns verbos irregulares. Artigos definidos (singular e plural).

Léxico específico: "O sistema jurídico italiano". Leitura e compreensão do léxico jurídico.

$3^{\text {a }}$ aula

Comunicação: Fazer pedidos no bar ou no restaurante, pedir algo que falta, pedir a conta.

Gramática: verbos regulares em -ere e alguns verbos irregulares. Advérbios interrogativos. 
Léxico específico: "O sistema jurídico italiano". Leitura e compreensão do léxico jurídico.

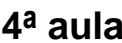

Comunicação: falar sobre o tempo livre, falar sobre gostos pessoais e preferências, concordar/discordar.

Gramática: verbos regulares em ire e alguns verbos irregulares. Indicação de tempo e de lugar; direção; dias da semana; negação; pronomes indiretos no singular.

Léxico específico: "O sistema jurídico italiano". Leitura e compreensão do léxico jurídico.

\section{5a aula}

Comunicação: reservar um quarto em um hotel, pedir informações; perguntar o preço do quarto; falar sobre objetos de uma casa; descrever o ambiente; alugar uma casa; justificar uma escolha.

Gramática: uso de c'è e ci sono; locuções de tempo; preposições simples; números e datas; como dizer as horas.

Léxico específico: "Ler as fontes do direito italiano". Leitura e compreensão do léxico jurídico.

\section{6⿳a aula}

Comunicação: descrever um lugar (cidade); descrever o percurso; lamentar-se; pedir informações sobre percursos.

Gramática: uso de ci com o verbo andare; adjetivos invariáveis; partitivos (plural); indicações de lugar; advérbios de interrogação.

Léxico específico: "Ler as fontes do direito italiano". Leitura e compreensão do léxico jurídico.

\section{$7^{\text {a }}$ aula}

Comunicação: contar eventos do passado; falar sobre as férias, locuções temporais no passado.

Gramática: o uso do passato prossimo (pretérito perfeito) com os auxiliares essere e avere (verbos regulares)

Léxico específico: "A hierarquia das fontes no direito italiano". Leitura e compreensão do léxico jurídico. 


\section{8aa aula}

Comunicação: saber contar fatos presentes e fatos passados

Gramática: o uso do passato prossimo com os auxiliares essere e avere (verbos irregulares)

Léxico específico: "A hierarquia das fontes no direito italiano". Leitura e compreensão do léxico jurídico.

\section{9a aula}

Comunicação: falar sobre compras e sobre os próprios hábitos; falar sobre produtos alimentícios; hábitos alimentares. Falar sobre as estações do ano.

Gramática: quantidade; partitivos (singular); pronomes pessoais do caso oblíquo (lo, la, li, le).

Léxico específico: "Direito Constitucional Italiano - Leis ordinárias". Leitura e compreensão do léxico jurídico.

\section{$10^{\text {a }}$ aula}

Comunicação: falar sobre o horário de trabalho e descrever a própria rotina com os hábitos e a frequência.

Gramática: verbos reflexivos; locuções de tempo; advérbios

Léxico específico: "Direito Constitucional Italiano - Leis ordinárias". Leitura e compreensão do léxico jurídico.

\section{$11^{\text {a }}$ aula}

Comunicação: saber descrever e comprar roupas; saber trocar peças de vestuários nas lojas; exprimir gostos e preferências: comparar.

Gramática: pronomes pessoais do caso oblíquo (tônicos e átonos); comparativos e diminutivos.

Léxico específico: "Direito Constitucional Italiano - Leis ordinárias". Leitura e compreensão do léxico jurídico.

\section{$12^{\mathrm{a}}$ aula}

Avaliação com nota. Apresentação de seminários pelos alunos. 


\section{2ํódulo}

1⿳亠丷a aula

Comunicação: falar da própria família; descrever uma fotografia; falar sobre coisas que possui.

Gramática: adjetivos possessivos; superlativo relativo; pretérito perfeito próximo dos verbos reflexivos.

Léxico específico: Direito Constitucional - Os decretos-lei.

\section{2a aula}

Comunicação: falar das lembranças da infância; descrever hábitos do passado.

Gramática: forma e uso do passado imperfeito

Léxico específico: Direito Constitucional - Os decretos-lei.

3a aula

Comunicação: descrever situações; defender a própria opinião argumentando favoravelmente ou contrariamente.

Gramática: locuções de tempo com o passado imperfeito; uso do passado próximo e do imperfeito.

Léxico específico: Direito Constitucional - Os decretos legislativos

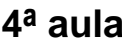

Comunicação: descrever uma pessoa fisicamente; falar sobre o caráter de uma pessoa.

Gramática: uso do verbo farcela, uso transitivo e intransitivo de cominciare e finire.

Léxico específico: Direito Constitucional - Os decretos legislativos

5a aula

Comunicação: perguntar alguma coisa gentilmente; fazer suposições.

Gramática: verbos sapere e andarsene; o comparativo (come/quanto); uso de qualcuno e nessuno.

Léxico específico: Comparação entre os sistemas: civil law e commom law

6a aula

Comunicação: fazer uma proposta; dar um conselho. 
Gramática: forma e uso do condizionale presente.

Léxico específico: Comparação entre os sistemas: civil law e commom law

\section{$7^{\mathrm{a}}$ aula}

Comunicação: fazer uma proposta; aceitar ou rejeitar uma proposta explicando o motivo; fazer uma contraproposta.

Gramática: stare + gerúndio; ce l'ho; pronomes pessoais do caso oblíquo com o pretérito perfeito.

Léxico específico: Direito Civil - A estrutura do contrato

\section{$8^{\mathrm{a}}$ aula}

Comunicação: contar o que está acontecendo naquele momento; marcar um encontro.

Gramática: advérbios (già/non...ancora); a posição dos pronomes com os verbos no infinitivo; pronomes relativos che e cui.

Léxico específico: Direito Civil - A estrutura do contrato

9a aula

Comunicação: pedir um favor; esclarecer uma intenção; informar-se sobre alguma coisa.

Gramática: o uso do pretérito imperfeito para exprimir um pedido e uma intenção; os verbos sapere e conoscere no pretérito imperfeito.

Léxico específico: Direito Civil - As obrigações

$10^{\mathrm{a}}$ aula

Comunicação: contar sobre as férias; demonstrar estupor e desprazer.

Gramática: o uso do pretérito perfeito e do imperfeito (II); nessuno + substantivo; verbo volerci.

Léxico específico: Direito Civil - Propriedade, detenção, posse e usucapião

$11^{\text {a }}$ aula

Comunicação: dar conselhos; falar sobre as próprias necessidades; dar uma opinião.

Gramática: imperativo (com TU); imperativo negativo na $2^{2}$ pessoa do singular.

Léxico específico: Direito Comercial - Tipos de empresas 
$12^{\text {a }}$ aula

Comunicação: falar sobre comida e hábitos alimentares.

Gramática: a posição dos pronomes no modo imperativo; o verbo servire.

Léxico específico: Direito Comercial - A sociedade em nome coletivo (s.n.c).

$13^{\text {a }}$ aula

Comunicação: falar sobre problemas de saúde; descrever sintomas; dar conselhos e indicações.

Gramática: imperativo (com LEl e VOI);

Léxico específico: Direito Comercial - A sociedade em comandita simples (s.a.s)

$14^{\mathrm{a}}$ aula

Comunicação: perguntar sobre atividades físicas e exprimir a própria opinião a respeito.

Gramática: imperativo negativo (com $L E l$ e VOI)

Léxico específico: O processo na Itália

$15^{\mathrm{a}}$ aula

Comunicação: falar com o intuito de convencer alguém.

Gramática: a posição dos pronomes com o imperativo; o comparativo e o superlativo de buono e bene.

Léxico específico: $O$ processo penal

16a aula

Avaliação de gramática (com nota).

Apresentação de seminários pelos alunos.

Quando as inscrições foram abertas, as vagas foram preenchidas rapidamente, e trinta alunos foram colocados em uma lista de espera, o que parece mostrar o grande interesse dos discentes pelo estudo do italiano jurídico.

O nosso objetivo, ao propor o curso, era analisar como se desenvolveria o trabalho com um grupo de aprendizes que nunca tinham estudado a língua 
italiana; talvez, isso não tenha ficado muito claro na divulgação do curso, pois, ao avaliarmos o perfil dos discentes no decorrer das primeiras aulas, verificamos que alguns deles já tinham estudado esse idioma. Realizamos uma pesquisa para analisar o perfil dos estudantes e para apurar quais eram as expectativas deles em relação ao curso. A seguir reportamos os resultados da nossa pesquisa inicial.

\section{RESULTADO DA PESQUISA INICIAL DOS DOIS GRUPOS PERFIL DOS ESTUDANTES}

\section{IDADE DOS ALUNOS:}

No grupo de sábado, vinte e sete discentes responderam o questionário. Quando Ihes perguntamos sobre a idade, obtivemos as seguintes respostas:

- $\quad 18$ a 20 anos de idade - três alunos;

- $\quad 21$ a 25 anos - dez estudantes;

- $\quad 26$ a 30 anos - dez;

- $\quad 31$ a 35 anos - dois;

- $\quad 36$ a 40 anos - dois.

No grupo de segunda-feira, trinta aprendizes responderam 0 questionário e, quanto à idade deles, as respostas foram estas:

- 17 anos - um aluno;

- $\quad 18$ a 20 anos - onze discentes;

- $\quad 21$ a 25 anos - nove;

- 26 a 30 anos - quatro;

- $\quad 31$ a 35 anos - três;

- $\quad 36$ a 40 anos - um; 
- $\quad 41$ a 45 anos - um.

Segue o gráfico com a porcentagem das idades dos estudantes dos dois grupos:

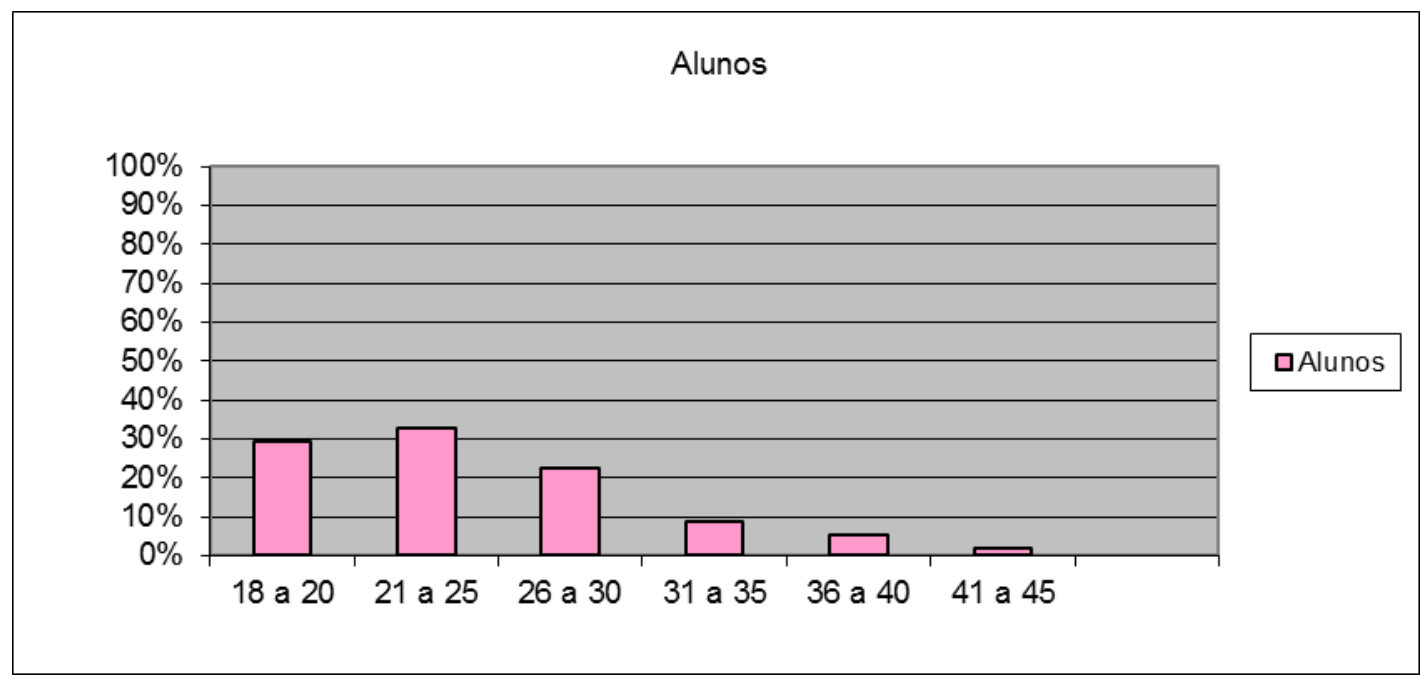

Gráfico 1 - Idade dos alunos

\section{GÊNERO}

No grupo de sábado, quinze alunos eram do sexo masculino, e doze, do sexo feminino; já no grupo de segunda-feira, dezesseis eram do sexo masculino, e catorze, do sexo feminino; é o que ilustra o gráfico abaixo:

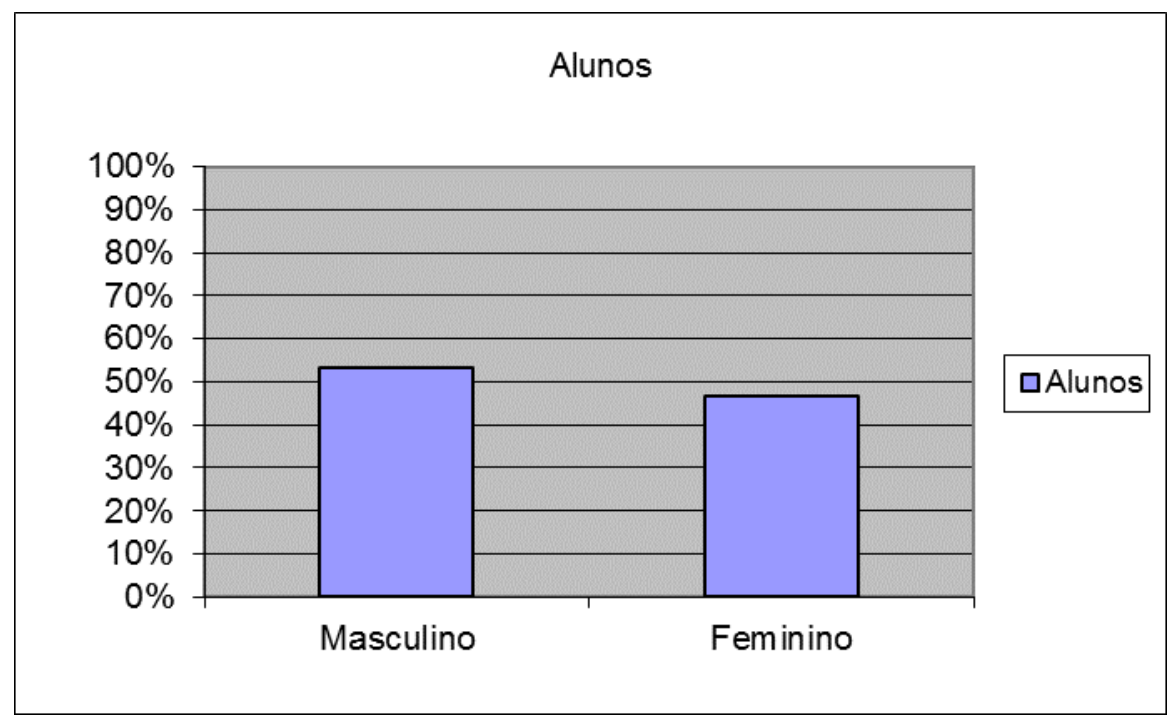

Gráfico 2- Gênero dos alunos 


\section{FORMAÇÃO DOS DISCENTES EM NÍVEL SUPERIOR}

No grupo de sábado, quinze alunos eram de graduação e treze de pósgraduação; no grupo de segunda-feira, os estudantes de graduação eram vinte, e os de pós-graduação, dez.

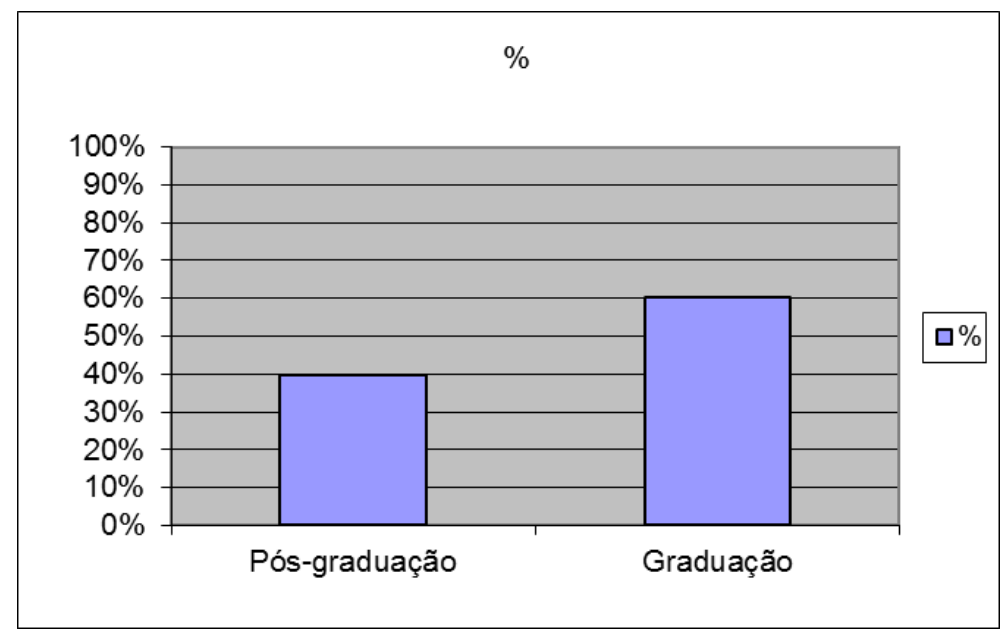

Gráfico 3- Formação dos discentes

\section{ÁREAS DE PÓS-GRADUAÇÃO}

Quando indagados sobre a área em que cursavam a pós-graduação, os aprendizes deram respostas variadas, que, no entanto, fazem parte do âmbito do Direito, como podemos observar pelo gráfico abaixo:

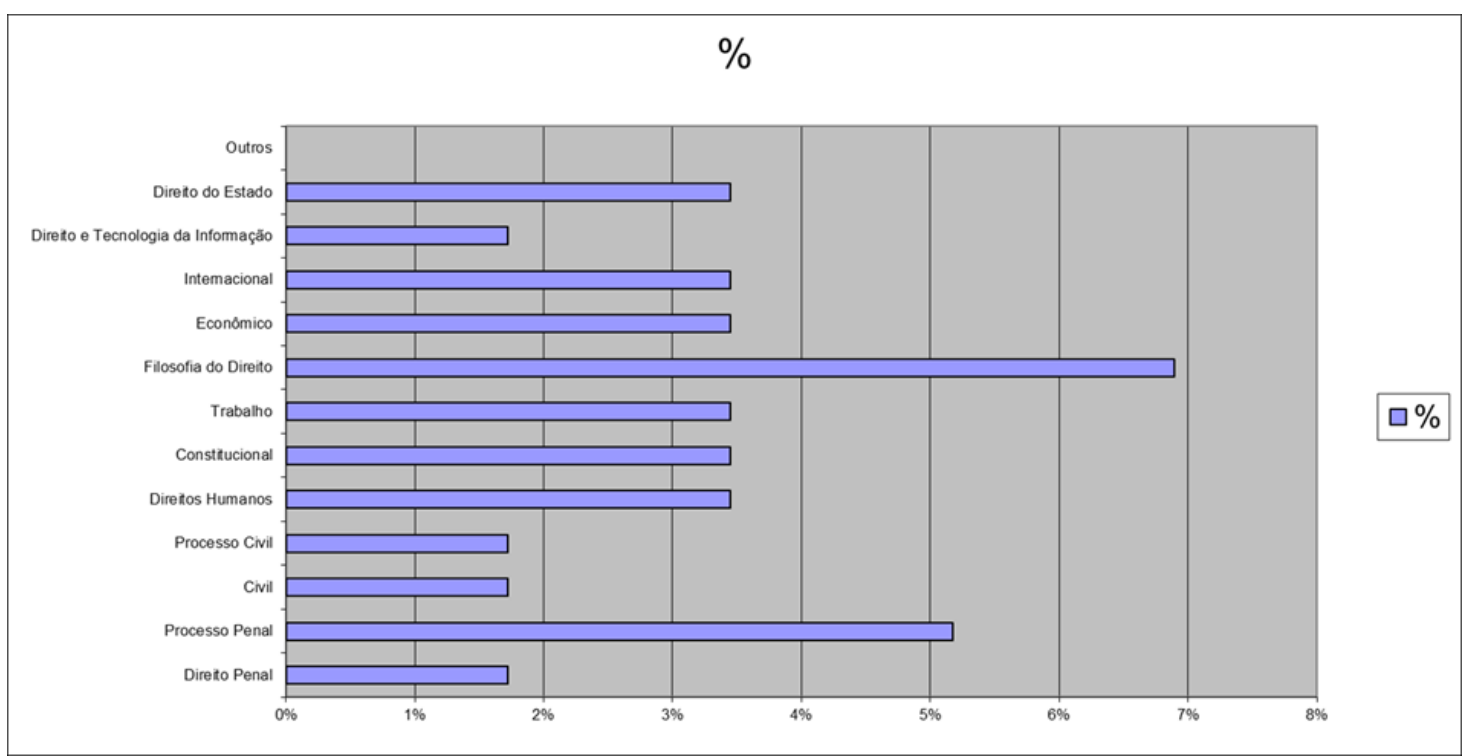

Gráfico 4- Áreas de Pós-graduação 


\section{ESTUDO DA LÍNGUA ITALIANA}

No grupo de sábado, catorze alunos já haviam estudado a língua italiana anteriormente, e catorze ainda não. No grupo de segunda-feira, catorze discentes já a tinham estudado antes, e dezesseis ainda não. É o que ilustra o gráfico seguinte:

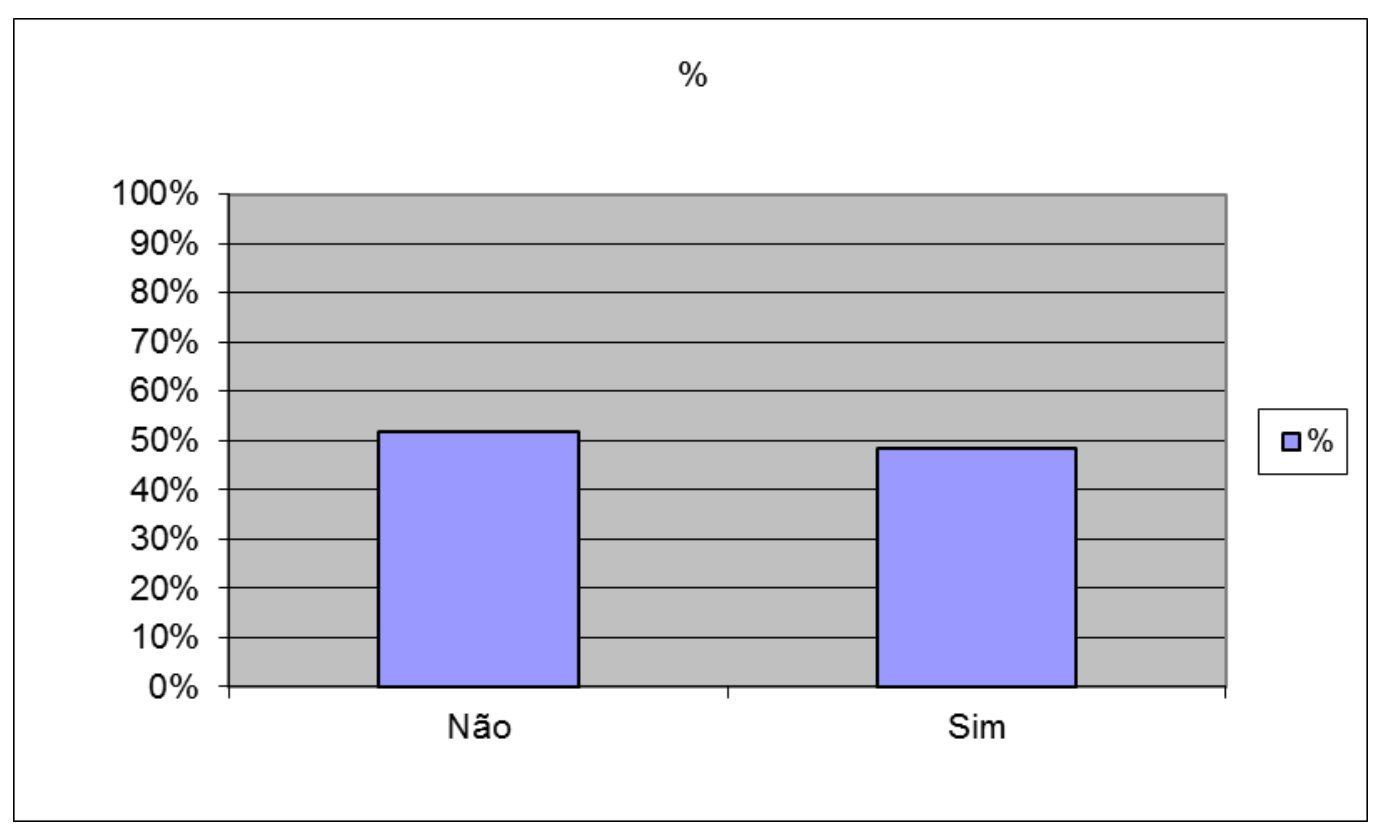

Gráfico 5- Alunos que estudaram anteriormente a língua italiana

\section{NÍVEL DE ESTUDO DO ITALIANO}

No grupo de sábado, dezesseis alunos declararam não ter nenhum conhecimento da língua italiana, seis declararam possuir o nível básico, e seis, o nível intermediário. No grupo de segunda-feira, quinze alunos declararam não ter nenhum conhecimento da língua italiana, oito afirmaram possuir o nível básico, seis, o nível intermediário, e um, o nível avançado. 


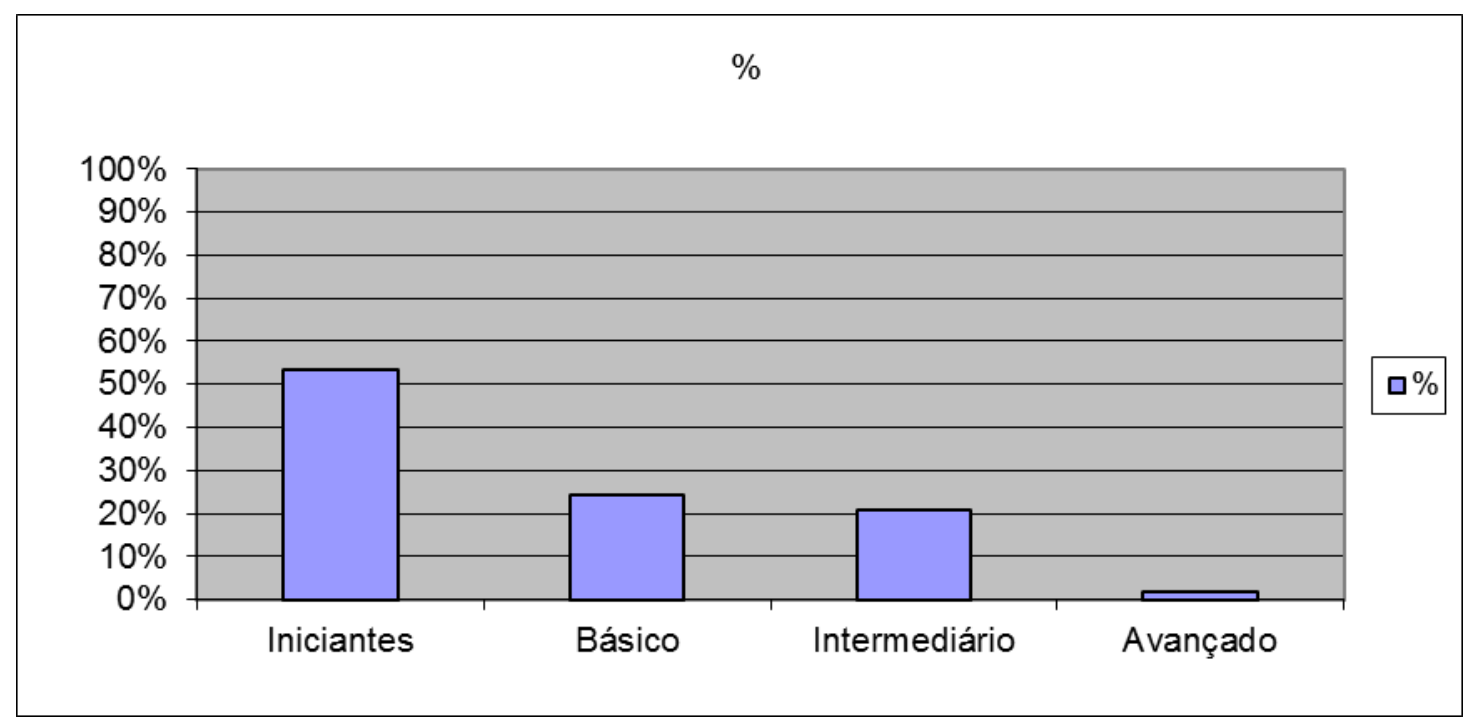

Gráfico 6 - Nível dos alunos

\section{ÊNFASE DO CURSO}

Quando perguntamos aos alunos o que eles queriam que fosse enfatizado no curso, obtivemos estas respostas: no grupo de sábado, treze responderam gramática, catorze, conversação, e catorze, leitura; no grupo de segunda-feira, dezessete responderam gramática, vinte e dois, conversação, dezesseis, leitura, e um aluno respondeu "outros".

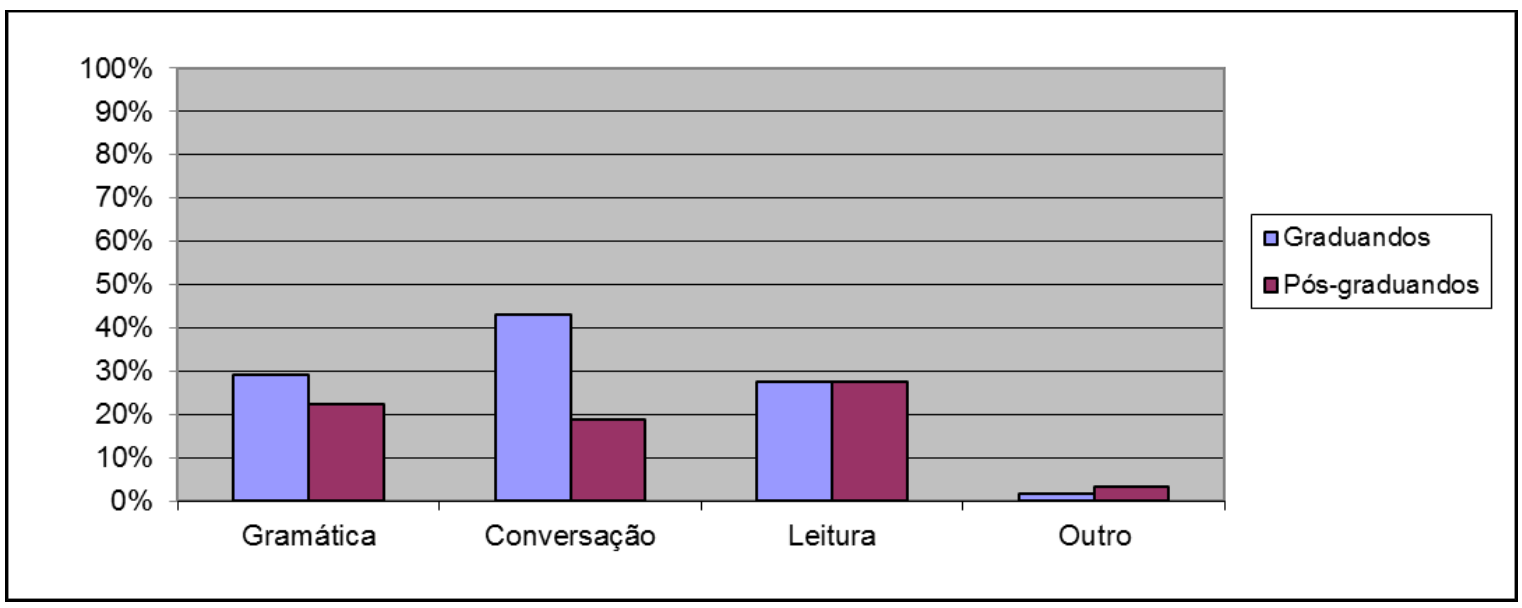

Gráfico 7- Ênfase dos alunos no curso 


\section{EXPECTATIVAS QUANTO AO CURSO}

Em relação às expectativas iniciais, pudemos observar que a maioria dos discentes pretendia, primeiramente, conhecer o idioma e, em segundo lugar, estudar a linguagem usada em textos jurídicos italianos. No questionário, alguns estudantes também mencionaram outras expectativas, como se pode ver no gráfico seguinte:

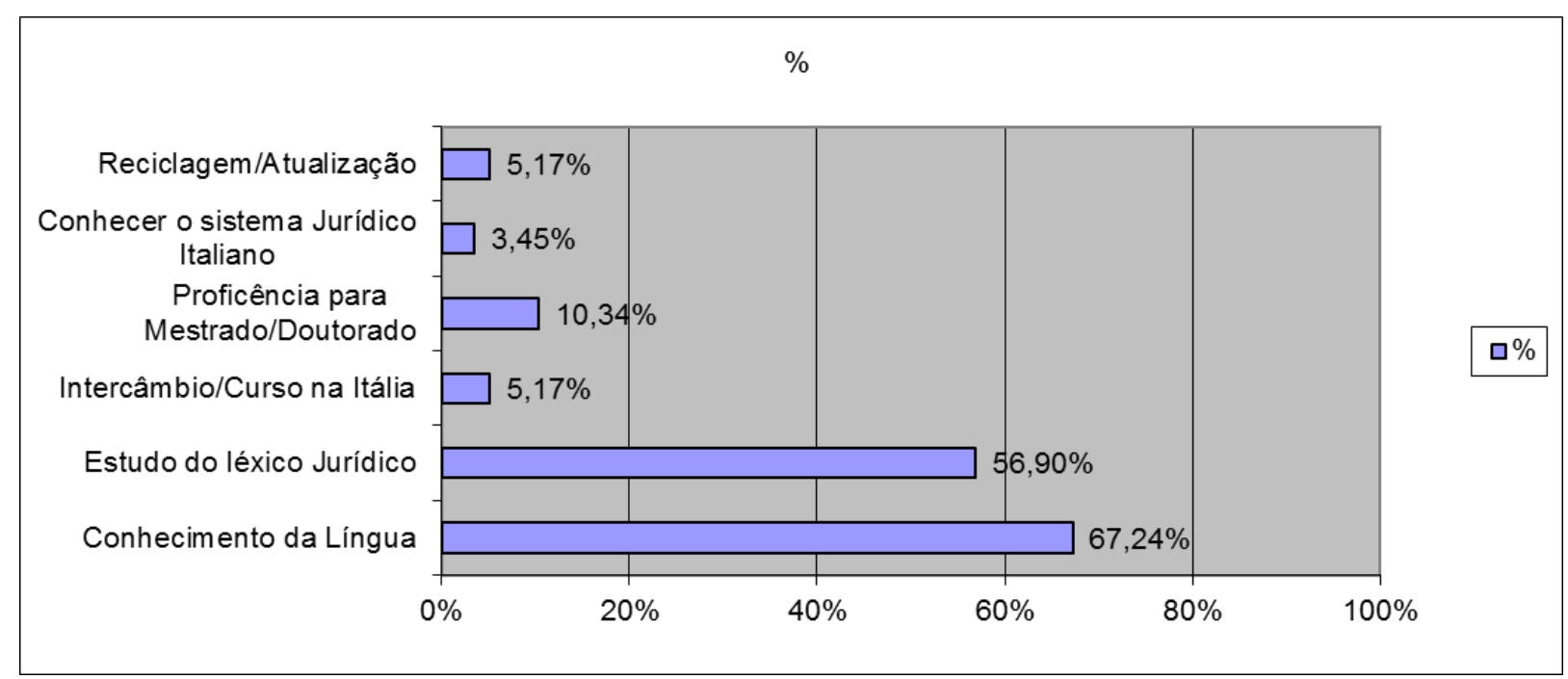

Gráfico 8- Expectativas dos alunos em relação ao curso

PORCENTAGEM DO INTERESSE EM RELAÇÃo AO GRAU DE INSTRUÇÃO

Como podemos observar pelo gráfico abaixo, os interessados em estudar o italiano jurídico são, em sua maioria, alunos de graduação do curso de Direito. 


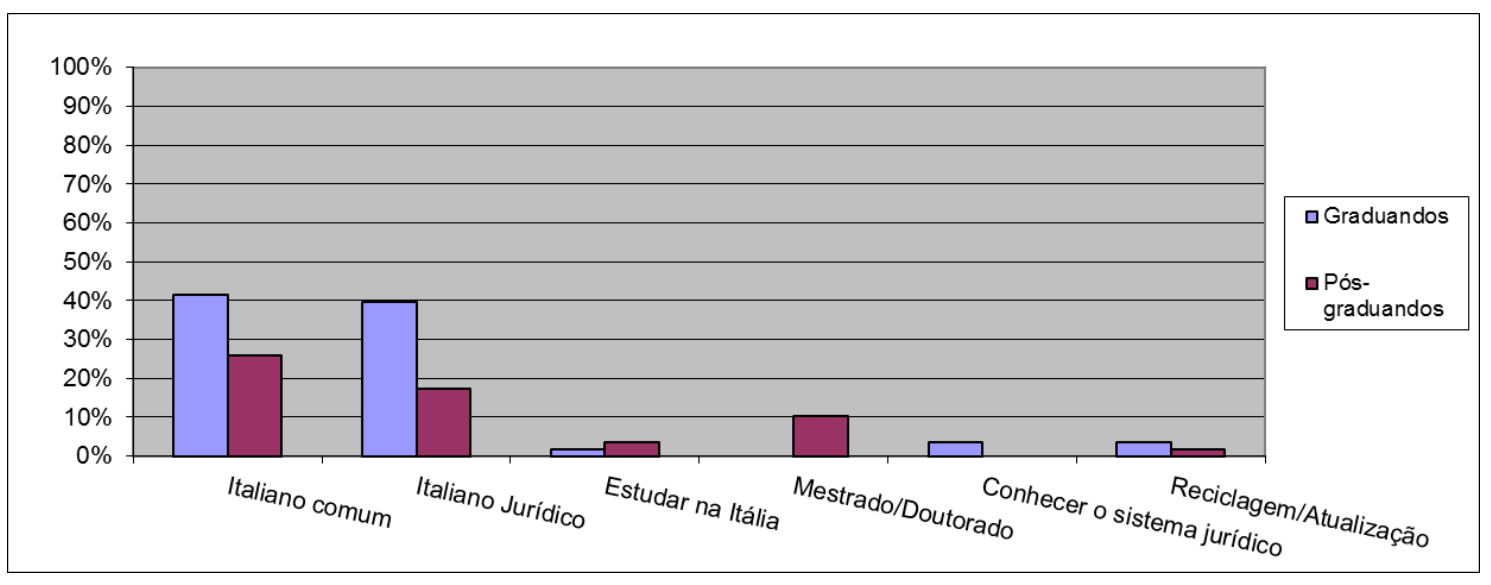

Gráfico 9- Interesse em relação ao grau de instrução

\subsection{1- Primeiro módulo}

Fizemos nossas observações a partir da programação original de cada aula, pois, a nosso ver, essa é a forma mais simples de discorrer sobre o andamento do curso. Como os grupos eram grandes, a nossa programação inicial ficou prejudicada, pois as aulas ocorriam de modo muito mais lento do que o esperado. No início, havíamos planejado trabalhar, em cada aula, uma hora e meia com o livro didático (Espresso I), e, em seguida, mais uma hora e meia com o manual de italiano jurídico. Decidimos fazer dessa maneira, pois o curso foi planejado para um grupo sem nenhum conhecimento da língua italiana. Porém, como mostraremos no decorrer desta dissertação, alguns alunos que se inscreveram no curso já tinham estudado a língua italiana anteriormente; alguns, inclusive, já tinham nível intermediário de conhecimento do italiano. 


\section{1a aula}

Considerações sobre a primeira aula: não foi possível seguir a programação completamente por dois motivos: em primeiro lugar, porque, por ser a primeira aula, os alunos não tinham providenciado, ainda, o material; em segundo lugar, porque quisemos conhecer um pouco sobre cada aluno e sobre o seu interesse no estudo da língua italiana. A parte do programa referente à comunicação e à gramática foi cumprida (faltou somente a explicação sobre o singular e o plural dos substantivos), pois conseguimos seguir o planejamento das aulas em que seriam trabalhados esses conteúdos. No entanto, como havia trinta alunos nos grupos e queríamos fazê-los praticar a língua oral, o trabalho levou mais tempo do que o previsto, principalmente porque, tendo em vista que era a primeira aula, eles ainda não se conheciam e, portanto, não se sentiam muito à vontade com os colegas. As atividades propostas tinham o objetivo de "quebrar o gelo" e fazer com que os estudantes se conhecessem, se apresentassem e também conhecessem um pouco sobre o trabalho desenvolvido pela professora. Para aprender a parte de fonética e fonologia, os alunos receberam uma cópia dos primeiros artigos da constituição italiana, e, por meio desse texto, demos aos discentes explicações quanto à pronúncia dos fonemas da língua italiana e quanto às diferenças entre estes e os da língua portuguesa. A primeira aula ocorreu de forma semelhante tanto no grupo de sábado quanto no de segundafeira, e todos os aprendizes responderam o questionário referente ao "perfil do aluno", para que pudéssemos conhecer melhor os grupos e, assim, fazermos a análise das necessidades desses discentes. Segue o questionário respondido por eles: 


\section{CURSO DE ITALIANO PARA JURISTAS}

\section{QUESTIONÁRIO}

Nome:

E-mail:

1) IDADE:
( ) de 18 a 20 anos
( ) de 21 a 25 anos
( ) de 26 a 30 anos
) de 31 a 35 anos
( ) de 36 a 40 anos
( ) de 41 a 45 anos
) de 46 a 50 anos
( ) de 50 a 55 anos
) de 61 a 65 anos
( )de 66 a 70 anos
( ) de 56 a 60 anos
( )acima de 70 anos

2) SEXO:

( ) masculino ( ) feminino

3) ESTADO CIVIL:
( ) solteiro
( ) convivente
( ) casado
( ) viúvo
( ) divorciado
( ) outro
4) TEM FILHOS?
( ) $\operatorname{sim}$
( ) não
5) É GRADUANDO? CURSA QUAL PERÍODO?

6) É PÓS-GRADUANDO? QUAL A ESPECIALIDADE?

7) COMO FICOU SABENDO DO CURSO?

8) JÁ ESTUDOU ANTERIORMENTE A LÍNGUA ITALIANA?
( ) $\operatorname{sim}$
( ) não

9) QUAL O NÍVEL, QUE VOCÊ ACREDITA TER ALCANÇADO, DO IDIOMA? ( ) nenhum ( ) básico ( ) intermediário ( ) avançado

10) QUAIS AS SUAS EXPECTATIVAS EM RELAÇÃO AO CURSO DE ITALIANO PARA JURISTAS?

11) O QUE VOCÊ GOSTARIA DE ESTUDAR COM MAIS PROFUNDIDADE?
( ) gramática ( ) conversação
( ) leitura
( ) outro. Especificar 


\section{$2^{\text {a }}$ aula}

Considerações sobre a segunda aula: Revisamos a parte referente à fonética e à fonologia, fazendo exercícios em que se trabalhava cada fonema. Em seguida, começamos a primeira unidade do livro Espresso, repassando alguns verbos (essere, avere e chiamarsi). Além disso, foram introduzidos os artigos definidos e os adjetivos de nacionalidade. Iniciamos a primeira unidade do livro Italiano per giuristi, que trata do sistema jurídico italiano; em seguida, explicamos detalhadamente aos estudantes cada atividade, realizando uma análise apurada de cada palavra vista. Sugerimos aos alunos que pesquisassem, no dicionário, as palavras desconhecidas e indicamos-lhes várias ferramentas de pesquisa online, bem como dicionários impressos.

\section{3a aula}

Considerações sobre terceira a aula: Iniciamos a unidade 02 do Espresso, explicando a diferença de uso dos pronomes de tratamento tu e lei e alguns verbos no presente indicativo. É importante ressaltar que cada conteúdo de gramática visto era trabalhado oralmente, em pequenos grupos, para que os aprendizes conseguissem praticar a pronúncia e memorizassem as palavras novas. Continuamos com a primeira unidade do manual Italiano per giuristi, fazendo atividades de leitura e compreensão de textos. No início desse trabalho, realizamos repetidas leituras dos mesmos textos, pois os alunos tinham dificuldade com a pronúncia e, assim, com a leitura em voz alta, fazíamos correções quando necessário. Começamos a perceber, principalmente no grupo de sábado, que alguns alunos se sobressaíam na compreensão dos textos e nos exercícios orais e fizemos uma "investigação" para saber se tais discentes já haviam estudado a língua anteriormente. 
Constatamos que muitos deles já a tinham estudado e possuíam um bom nível de conhecimento do italiano. Decidimos, então, fazer um teste para ver qual era o nível desses alunos. Notamos que para alguns, os conteúdos vistos nas aulas pareciam ser muito fáceis, o que poderia torná-las desmotivadoras para esses aprendizes. Por isso, marcamos o teste para o final do primeiro mês de aula.

\section{4⿳亠口冋口 aula}

\section{Considerações sobre a quarta aula:}

Fizemos o teste com os alunos dos dois grupos e obtivemos o seguinte resultado:

\section{Grupo de sábado:}

Total de alunos que fizeram o teste: 25

Total de alunos pré-iniciantes: 12

Total de alunos com o nível básico: 07

Total de alunos com o nível intermediário: 05

Total de alunos com o nível avançado: 01

\section{Grupo de segunda-feira:}

Total de alunos que fizeram o teste: 20

Total de alunos pré-iniciantes: 12

Total de alunos com o nível básico: 02

Total de alunos com o nível intermediário: 05

Total de alunos com o nível avançado: 01 


\section{GRÁFICO DA PESQUISA INICIAL}

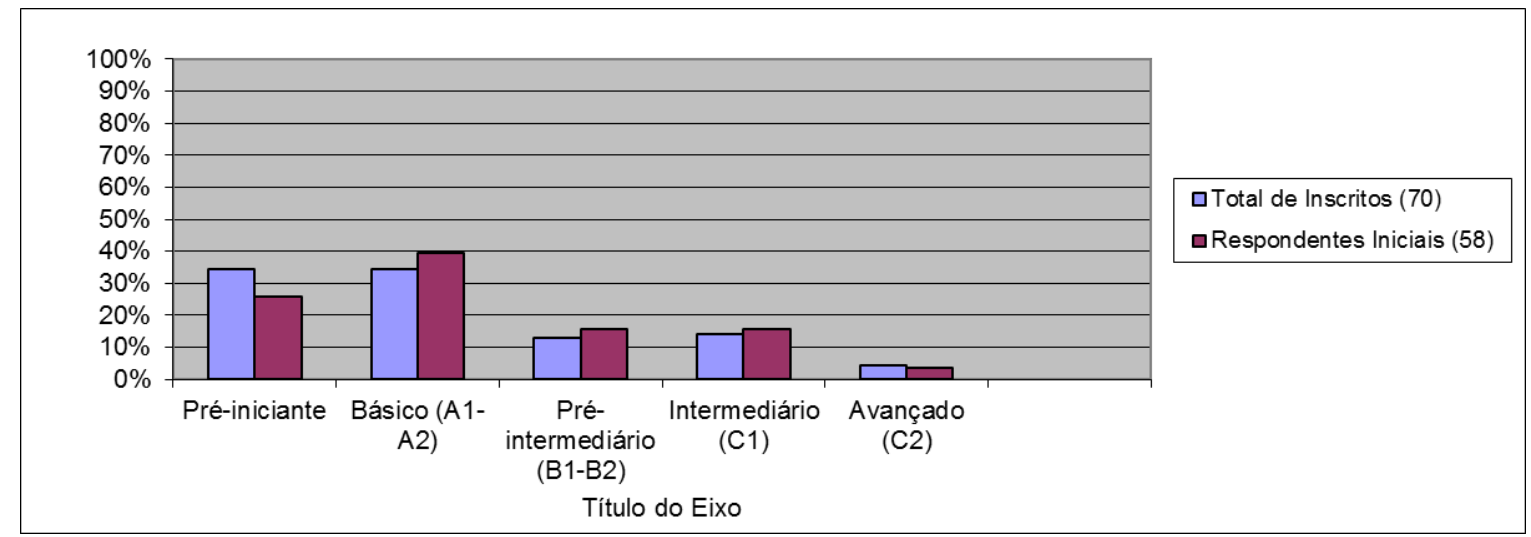

Gráfico 10- nível de conhecimento dos alunos (primeiro questionário)

O gráfico acima corresponde às respostas dos discentes à pesquisa inicial. Ao compará-lo com o gráfico que fizemos após o teste, percebemos que a maioria dos estudantes tinha noção do seu próprio nível de conhecimento do italiano, como podemos verificar no gráfico abaixo:

\section{GRÁFICO DO NÍVEL DOS ALUNOS APÓS O TESTE}

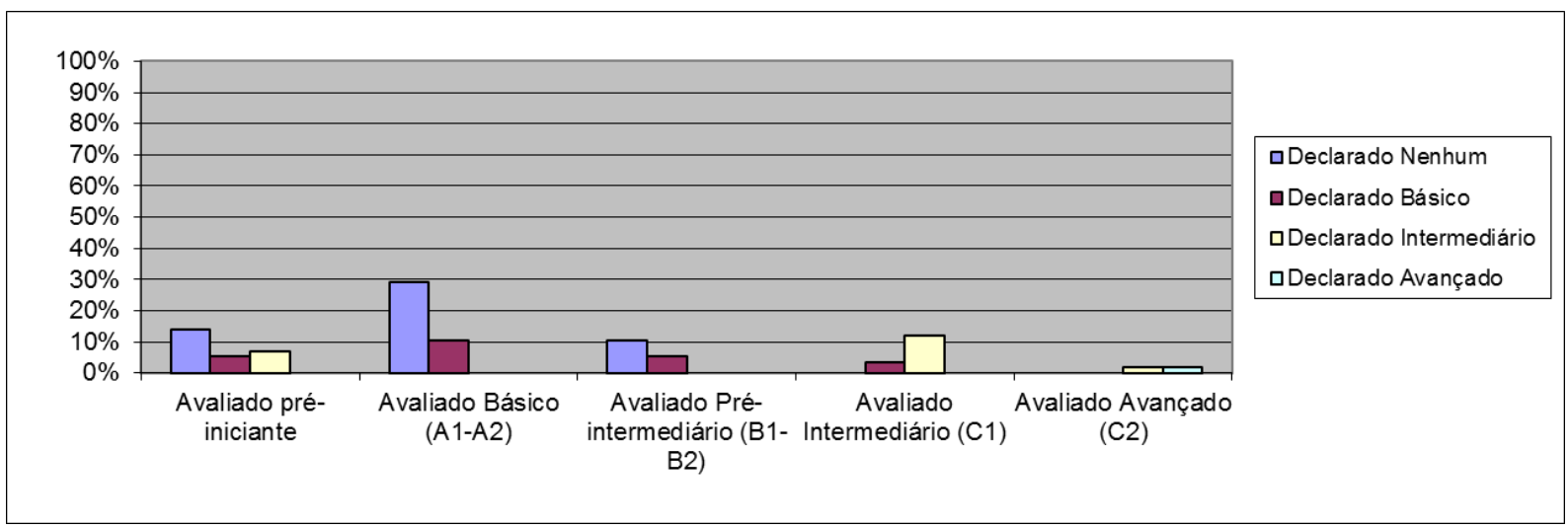

Gráfico 11- Nível dos alunos de acordo com o teste

Alguns alunos não quiseram realizar o teste, pois disseram que nunca haviam estudado o idioma. A partir dos resultados obtidos com a realização 
desse teste de nível, decidimos fazer uma experiência com os aprendizes do grupo de sábado, a qual foi realizada na sexta aula

\section{$5^{\mathrm{a}}$ aula}

Considerações sobre a quinta aula: Continuando com a segunda unidade do Espresso, vimos os numerais, os artigos definidos e indefinidos; depois, fizemos exercícios orais e escritos para praticar esses conteúdos. Iniciamos a segunda unidade do Italiano per Giuristi, na qual trabalhamos a leitura das fontes do Direito. Os alunos iniciantes tinham dúvidas quanto ao vocabulário, mas em relação ao conteúdo não tinham muita dificuldade, pois comparavam o que estavam aprendendo com o que já haviam estudado na faculdade de Direito; ademais, comentavam as diferenças entre aquilo que sabiam do direito brasileiro e o conteúdo apresentado pelo livro. Como já dissemos anteriormente, o manual é bem simplificado, e, no início do curso, os estudantes faziam a leitura sempre em voz alta. Além disso, como os grupos eram grandes, a leitura era feita coletivamente: cada discente lia uma parte do texto, e, ao final, lia-se o mesmo texto várias vezes, o que ajudava os aprendizes a memorizar os termos vistos e o conteúdo estudado.

\section{6a aula}

Considerações sobre a aula: Começamos a unidade 03 do Espresso, e os alunos produziram diálogos em que simulavam situações em um bar ou em um restaurante. Durante essa aula, no grupo de sábado, solicitamos a alguns aprendizes (aqueles que, de acordo com o teste de nível realizado, tinham os níveis intermediário ou avançado de conhecimento do italiano), que fizessem um trabalho paralelo que, depois, seria apresentado para a classe. Esses 
alunos foram para outra sala e deveriam executar a seguinte tarefa: ler os primeiros artigos da Constituição italiana e encontrar, na Constituição brasileira, os artigos correspondentes.

O trabalho deveria ser realizado desta maneira: em primeiro lugar, fariam uma leitura dos artigos indicados pela professora, procurando compreender o texto e buscando, no dicionário, as palavras desconhecidas. A seguir, cada aluno escolheria um artigo e faria a pesquisa na Constituição brasileira para encontrar o artigo correspondente. A discussão no grupo deveria ser feita em italiano, e os discentes que tivessem mais facilidade deveriam auxiliar os que tivessem mais dificuldade. Todo esse trabalho seria realizado sem a presença da professora, pois a aula continuaria normalmente com o restante da turma. Ao final da pesquisa realizada pelo grupo, cada aluno produziria um texto sobre a parte que havia pesquisado e o apresentaria para a classe no fim da aula. Os objetivos eram trabalhar o vocabulário usado na Constituição italiana e compará-la à brasileira, para, em seguida, falar brevemente sobre as semelhanças e diferenças entre ambas e escrever um texto referente a essa comparação. Convém salientar que, em tal atividade, não era necessária uma profunda reflexão jurídica sobre o assunto.

Acreditamos que a experiência tenha sido válida, no entanto é importante ressaltar alguns aspectos:

1) Alguns alunos tinham dificuldade até mesmo de tentar falar em italiano.

2) Alguns alunos queriam realizar todo o trabalho oralmente, e outros queriam fazê-lo por escrito. 
3) Aqueles que tinham dificuldade de produzir textos escritos em italiano queriam, primeiramente, escrever em português e, posteriormente, fazer a tradução.

4) No momento da apresentação, uma das alunas não conseguiu falar sequer uma frase em italiano.

5) Houve, entre os discentes, certa "disputa" pela liderança do grupo, o que prejudicou, em parte, a realização do trabalho. Em certo momento, precisamos interferir nas discussões, pois os alunos começaram a se indispor uns com os outros, já que cada um queria fazer a atividade de um jeito diferente. Sabemos que, quando se realizam trabalhos em grupos, podem acontecer esses desentendimentos, porém, inocentemente, esperávamos que isso não tivesse acontecido.

6) Apesar desses problemas, quase todos os estudantes fizeram uma ótima apresentação. Alguns leram suas anotações, mas a maioria conseguiu falar, com muita desenvoltura, o que tinha pesquisado. Esse foi o aspecto mais positivo da realização de tal experiência.

Porém, por causa dos desentendimentos, decidimos que os trabalhos posteriores de pesquisa seriam realizados individualmente, como tarefa de casa. Paralelamente, na aula, iniciamos a terceira unidade do Italiano per Giuristi, trabalhando o vocabulário relacionado à "hierarquia das fontes do Direito".

\section{$7^{\mathrm{a}}$ aula}

Considerações sobre a sétima aula: continuando a unidade 03 do Espresso, foram apresentados alguns verbos irregulares no presente do indicativo. Observamos que a parte gramatical e a comunicação precisavam ser 
trabalhadas com mais profundidade, portanto não podíamos trabalhar os conteúdos apressadamente. Era necessário praticar muito: o uso do singular e do plural; o uso dos artigos; o uso do tratamento formal e informal; e a pronúncia. Para os alunos que já tinham estudado a língua italiana, esse trabalho era apenas uma revisão, mas, para os iniciantes, os conteúdos trabalhados eram complexos. Por esse motivo, precisávamos dar atenção especial aos discentes principiantes, já que eles eram o nosso público-alvo.

No decorrer das aulas, percebemos que alguns alunos (que já tinham níveis mais avançados) começaram a desistir do curso, pois, como alguns nos disseram, não era motivador rever o conteúdo que já conheciam. As desistências ocorreram em maior número no grupo do sábado de manhã. Acreditamos que isso tenha acontecido também por causa do horário das aulas: como muitos alunos trabalham e estudam durante a semana toda, preferem descansar no fim de semana. Algumas desistências ocorreram por motivo de viagem; alguns aprendizes faltaram às aulas mais do que o permitido (três faltas); uma das estudantes disse que, ao fazer a inscrição, não tinha ficado claro que o curso era voltado para alunos iniciantes. Na verdade, parece-nos que alguns alunos não leram todas as informações referentes ao curso, pois ao divulgá-lo, fizemos constar na programaçao que as aulas se destinavam a principiantes, Talvez, por se tratar de um curso gratuito, muitos aprendizes inscreveram-se instantaneamente, sem ler com cuidado todas as informações.

Quando começaram a ocorrer as desistências, não ficamos muito preocupados, pois, pela nossa experiência anterior, já sabíamos que os cursos gratuitos têm muitos alunos inscritos, porém, após certo tempo, alguns 
estudantes param de frequentar as aulas. Por tal motivo, também, ao abrir as inscrições, determinamos que cada grupo deveria ter, no máximo, trinta discentes. Sabemos que uma classe em que se trabalham as quatro habilidades primárias não deve ser muito numerosa, no entanto o nosso curso consistia em uma experiência, e queríamos observar e analisar todos esses detalhes. Na sétima aula, continuamos estudando a hierarquia das fontes no direito italiano, com base nos textos da terceira unidade do Italiano per Giuristi.

\section{$8^{\mathbf{a}}$ aula}

Considerações sobre a oitava aula: iniciamos a unidade 04 do Espresso, e os alunos praticaram a produção oral, falando sobre o tempo livre e sobre as suas preferências e gostos pessoais.

Quanto à gramática, continuamos a trabalhar os verbos irregulares no presente do indicativo. Em relação ao Italiano per giuristi, começamos a quarta unidade, em que trabalhamos o vocabulário referente às leis ordinárias.

\section{9a aula}

Considerações sobre a nona aula: continuando a unidade 04 , vimos os dias da semana, os pronomes pessoais do caso oblíquo (tônicos e átonos), os advérbios interrogativos e o verbo piacere (mi piace, mi piacciono).

Durante essa aula, explicamos aos aprendizes a atividade que eles deveriam apresentar na última aula do primeiro módulo: cada aluno deveria escolher um tema concernente ao Direito (italiano), pesquisar sobre esse tema, escrever a respeito dele e estudar o texto escrito para apresentar em forma de seminário à classe. Cada estudante deveria fazer uma apresentação em power point para os colegas, ou entregar cópias do texto ao grupo. Essa apresentação seria 
filmada por nós, para que pudéssemos avaliar com segurança o desempenho de cada aluno.

\section{$10^{\mathrm{a}}$ aula}

Considerações sobre a décima aula: Iniciamos a unidade 05 do Espresso e vimos o uso de c'è e ci sono e de algumas preposições. Os alunos realizaram diálogos, simulando a reserva de um hotel; além disso, pediram informações sobre hospedagem, fizeram reclamações a respeito de coisas que não funcionavam no hotel. Trabalhamos, também, atividades em que eles conheceram palavras e frases que podem ser usadas para alugar um imóvel e para descrever uma casa ou um apartamento.

Iniciamos a quinta unidade do Italiano per giuristi e vimos como nasce um Decreto-Lei na Itália, dentro dos parâmetros constitucionais italianos.

\section{$11^{\text {a }}$ aula}

Considerações sobre a décima primeira aula: Terminamos a unidade 05 do Espresso e fizemos uma revisão dos conteúdos gramaticais vistos durante as aulas, para que os alunos pudessem se preparar para a avaliação que aconteceria na aula subsequente.

Concluímos nosso estudo sobre o Decreto-Lei na Itália (Italiano per giuristi, unidade 05) e esclarecemos as dúvidas dos discentes quanto à apresentação do seminário que ocorreria na aula seguinte. 


\section{$12^{\mathrm{a}}$ aula}

Considerações sobre a décima segunda aula: em primeiro lugar, fizemos uma avaliação escrita dividida em duas partes: a primeira referia-se a alguns conteúdos gramaticais, e a segunda consistia numa atividade de leitura e compreensão de um texto jurídico. Com essa avaliação, pretendíamos verificar a apreensão dos conteúdos trabalhados, bem como a compreensão textual por parte dos alunos. Com o seminário, que seria apresentado na segunda parte da aula, visávamos avaliar a compreensão de textos escritos, a leitura oral e a pronúncia. Mostramos, abaixo, a avaliação escrita que elaboramos para os aprendizes:

\section{VALUTAZIONE CORSO DI ITALIANO PER GIURISTI- 1 LIVELLO}

Prof.ssa Quézea Regina Albolea Mastelaro

Nome:

Data:

1. Mettere l'articolo determinativo giusto:

Italia è una penisola e ha forma di uno stivale. capitale dell'Italia è Roma. Venezia, Milano, Torino, Bologna, Firenze sono città del nord. Roma è al centro. Napoli è al sud. Italia ha due grandi isole: Sicilia e Sardegna. Corsica è un'isola francese. fiume più lungo è Po; altri fiumi importanti sono Arno e

Tevere. In Italia ci sono molti laghi bellissimi: lago di Como, lago di Garda, lago d'Iseo e lago Maggiore sono al Nord. lago Trasimeno e Lago di Bracciano e Bolsena sono al centro. Le Alpi e gli Appennini sono due catene di montagne molto importanti. Monte Bianco è nelle Alpi ed è montagna più alta. In Italia ci sono tre vulcani attivi: Vesuvio, Etna e Stromboli. Italia è una repubblica ed è divisa in 20 regioni. In Italia ci sono due piccoli stati indipendenti: San Marino e Vaticano. In Vaticano c'è Papa. 


\section{Completa le frasi con i verbi:}

1- Noi (essere) di Milano.

2- Maria e Giuseppe (abitare) a Venezia.

3- Marcello (lavorare) in un ristorante.

4- lo (fare) la segretaria.

5- Lei (chiamarsi) Antonella e il marito (chiamarsi) Mario.

6- Oggi noi (prendere) un cappuccino e un cornetto.

7- Anche voi (preferire) il vino rosso?

8- Carlo (volere) sposare Marina, ma lei non lo ama.

9- Sofia (avere) una Ferrari e Marco (avere) una Fiat.

10- Dario, (stare) a casa tutta la giornata?

11- Il pomeriggio io (andare) in palestra.

12- Serena, che cosa (fare) il finesettimana? (Dormire) a lungo o (andare) in piscina?

13- Voi (ascoltare) la musica classica oppure (preferire) la musica rock?

14- lo (leggere) molto perché devo fare gli esami.

15- Ogni giorno Sandra (cucinare) per la famiglia.

16- Signor Giannini, (venire) al bar con noi?

17- Mi scusi, (potere) ancora un po' di zucchero?

18- Qui vicino (c'è/ci sono) un ristorante tipico.

19- (mi piace/mi piacciono) la pizza.

20- A noi (piace/piacciono) fare sport.

\section{3- Completa il testo con i verbi al presente indicativo e i tuoi dati personali:}

(chiamarsi) (nome) (essere) (professione) (abitare) (città)

Nel tempo libero mi piace 


\section{Leggi il testo e rispondi alle domande:}

\section{REGOLE GIURIDICHE}

È regola giuridica (regola di comportamento assistita dalla forza dello Stato) la regola contenuta in una legge del Parlamento. Tra regola generale e astratta e regola concreta vi è una differenza non piccola.

La regola generale e astratta è quella regola formulata in termini tali da poter essere applicata un numero indeterminato di volte: essa dunque, per questa sua qualità, è generale perché si applica ad una generalità di persone (non a questa o a quella in particolare), ed è astratta perché non si riferisce ad una situazione già verificatasi, ma ad indeterminate situazioni future.

Esattamente all'opposto la regola concreta si riferisce a quella o quell'altra persona determinata $e$, in genere, integra una regola generale e astratta con alcuni elementi particolari che si possono applicare solo a quel caso concreto considerato. Per conseguenza la regola generale e astratta si applica un numero indeterminato di volte, la regola concreta si applica a quel caso determinato e muore con il finire di quel caso.

La scienza che si ocupa essenzialmente delle regole generali e astratte così come sono state formulate dal legislatore (nel senso più ampio del termine) è la scienza del diritto o scienza giuridica (giurisprudenza invece in Italia indica il diritto interpretato dai giudici, l'opinione dei giudici rispetto alle regole generali e astratte).

Spesso anziché scienza del diritto o scienza giuridica si usa puramente e semplicemente la parola "diritto", aggiungendo quase sempre la specificazione del ramo del diritto a cui ci si riferisce (e cioè diritto civile o privato, diritto commerciale, diritto costituzionale ecc.). Così la parola "diritto" acquista un significato per lo meno duplice: ora designa l'oggetto della conoscenza, la parte di realtà che vogliamo studiare (e cioè l'insieme di quelle regole generali e astratte che compongono il diritto); ora designa la disciplina scientifica che studia tale oggetto. L'insieme delle regole generali e astratte vigenti in un certo paese costituisce il diritto di tale paese. Questo diritto però si applica a sfere diverse della realtà sociale e talvolta, proprio per questa diversità, presenta differenze di principio tra ramo e ramo del diritto. Così ad esempio, venendo alla divisione fondamentale entro il diritto moderno, quella tra diritto privato da un lato e diritto pubblico dall'altro, il diritto privato, che si riferisce essenzialmente ai rapporti tra privati posti in condizioni di eguaglianza giuridica (nessuno può comandare sull'altro, ma i privati si obbligano l'uno verso l'altro solo per mutuo consenso), è governato dal principio della autonomia privata, per cui il privato detta le regole a se stesso; nel diritto pubblico invece prevale il momento dell'autorità, per cui il soggetto pubblico può imporre unilateralmente la sua volontà ai cittadini. Le principali partizioni entro il diritto privato sono quelle di diritto civile, diritto commerciale, diritto del lavoro; entro il diritto pubblico sono quelle di diritto costituzionale, diritto amministrativo, diritto penale, diritto processuale penale, diritto processuale civile. A parte sta il diritto Internazionale (pubblico), che non è diritto di uno Stato, ma diritto dell'ordinamento internazionale composto dagli Stati. 
1- Una regola giuridica è una regola di comportamento stabilita dallo Stato. $(0,3)$

( ) vero

( ) falso

2- Uma regola giuridica è scritta in una legge. $(0,3)$

( ) vero

( ) falso

3- La regola generale e astratta si applica un numero indeterminato di volte. $(0,3)$

( ) vero

( ) falso

4- La regola generale e astratta si riferisce a situazioni determinate. $(0,3)$

( ) vero

( ) falso

5- La regola concreta si riferisce a un caso determinato. $(0,3)$

( ) vero

( ) falso

6- La scienza che si occupa delle regole generali e astratte è $(0,5)$

( ) la giurisprudenza.

( ) una scienza astratta.

( ) la scienza del Diritto.

7- La parola diritto designa $(0,5)$

( ) l'insieme delle regole generali e astratte.

( ) solo um ramo del diritto.

( ) la realtà sociale.

8- Il diritto si divide in $(0,5)$

( ) vari rami.

( ) varie sfere.

( ) regole generali e astratte.

9- La divisione fondamentale entro il diritto moderno è $(0,5)$

( ) tra diritto civile e diritto commerciale.

( ) tra diritto costituzionale e diritto amministrativo.

( ) tra diritto pubblico e diritto privato.

10- Il diritto privato riguarda i rapporti $(0,5)$

( ) di lavoro tra i singoli cittadini.

( ) giuridici tra i singoli cittadini.

( ) tra Stato e cittadini.

11- II diritto pubblico è governato dal principio $(0,5)$

( ) dell'autorità.

( ) dell'autonomia. 


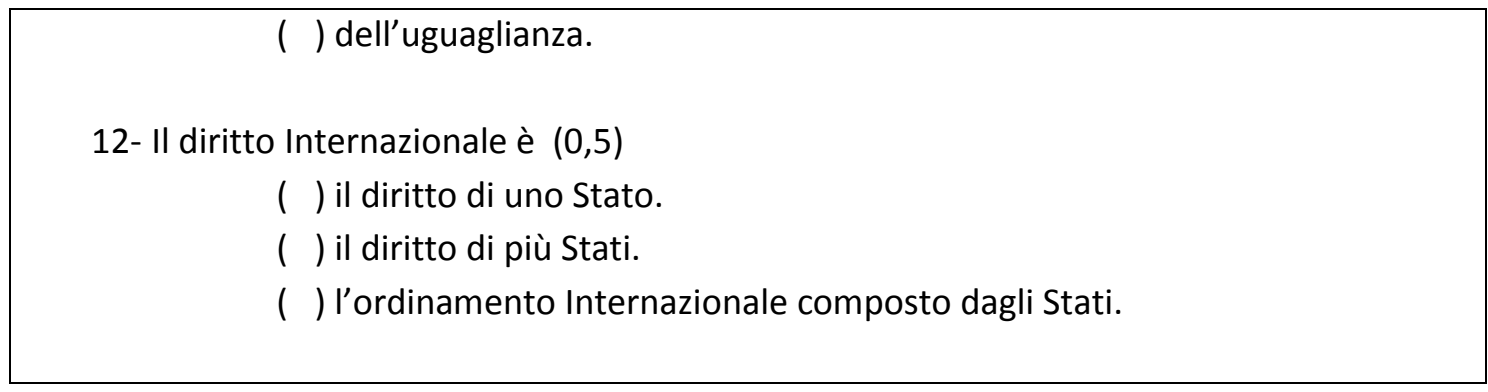

\section{Resultado das avaliações:}

\section{Grupo de sábado:}

Como já mencionamos, houve um grande número de desistentes no grupo de sábado. Alguns, inclusive, frequentaram até as últimas aulas, porém não compareceram no dia da avaliação. Portanto, realizaram a avaliação somente onze alunos e todos foram aprovados. As notas deles ficaram entre 9 e 10, o que nos deixou muito satisfeitos. Tais estudantes mostraram-se, ao longo do curso, muito dedicados, e isso explica o desempenho deles na avaliação.

Em relação à apresentação oral, o mínimo que exigimos era que os discentes lessem o texto pronunciando corretamente as palavras. $O$ ideal era que os alunos tentassem apresentar, de maneira espontânea e natural, o assunto pesquisado, mesmo que falassem acerca deste somente por um minuto (o tempo médio era de 5 minutos de apresentação para cada estudante), mas, levando em consideração que os aprendizes eram iniciantes, o nosso grau de exigência foi menor. Todas as apresentações foram filmadas, e a parte escrita de alguns trabalhos estão em anexo.

Ao final do primeiro módulo, pedimos que os alunos respondessem um questionário de avaliação do curso para que pudéssemos planejar melhor o segundo módulo. Transcrevemos, aqui, a opinião dos doze alunos que o 
responderam. As perguntas foram numeradas de 01 a 08 , e os alunos foram identificados por letras (de A a L).

1) As suas expectativas iniciais a respeito do curso de Italiano para Juristas foram alcançadas?

Respostas:

A- "Sim, por ser iniciante, não ter feito aulas do idioma anteriormente acho que a esquematização do curso foi bastante interessante".

B- "Sim. Tinha a expectativa de iniciar o estudo da língua, porém, já tendo contato com o vocabulário específico do Direito. Isso se concretizou plenamente durante o curso".

C- "Sim. A proposta do curso foi alcançada, de acordo com minhas expectativas, pois foram ensinadas as bases da língua italiana por meio de textos jurídicos, o que torna o aprendizado mais interessante para os estudantes de Direito".

D- "Consegui desenvolver um bom entendimento da língua italiana, sobretudo em textos jurídicos. Por ser iniciante, julgo que as bases gramaticais da língua foram passadas de forma clara e apropriada para os iniciantes".

E- "Sim, o contato com a língua, a revisão de regras de gramática e o aprendizado de outras, bem como a melhoria da pronúncia eram os meus principais objetivos. Gostei bastante de aprender o básico sobre 0 ordenamento jurídico italiano".

F- "As minhas expectativas quanto ao curso foram sim alcançadas, pois eu já esperava as noções introdutórias da língua italiana, assim como foi 
ensinado. Em relação à parte do italiano jurídico, eu esperava que a professora fosse além do livro didático e utilizasse mais textos de juristas italianos. De qualquer forma, minhas expectativas foram sim satisfeitas".

G- "Sim, retomei meu italiano e de quebra aprendi muitas coisas novas".

H- "Sim. Aprendi muitas palavras relacionadas ao direito. Conheci um pouco da Constituição Italiana e do Código Penal".

I- "Sim. As expectativas iniciais foram alcançadas, pois pude conhecer a língua italiana de forma ampla dando-me instrumentos para leitura e comunicação básica".

J- "Sim. Minha expectativa inicial repousava sobretudo no aprendizado da língua italiana. Considero muito positivo o curso e espero com ansiedade o segundo módulo".

K- "Sim, minhas expectativas foram amplamente alcançadas, pois, apesar de circunstancias pessoais não terem me permitido um estudo aprofundado, a abordagem didática despertou meu interesse pela língua italiana para estudos futuros".

L- "Sim".

\section{2) Qual a sua opinião sobre o livro Italiano per giuristi?}

A- "Livro interessante que traz aspectos gerais e introdutórios do direito italiano, pelas noções que possuímos do direito brasileiro é bastante interessante no que concerne às comparações entre os dois sistemas, além de trazer vocabulário específico, técnico". 
B- "Considero o livro adequado para os seus propósitos, pois ele propicia o conhecimento da estrutura básica do Direito italiano, ao mesmo tempo em que introduz, paulatinamente, os termos específicos dessa área do conhecimento".

C- "É um livro interessante, que se encaixa perfeitamente com a proposta do curso".

D- "O livro apresenta a estrutura do ordenamento jurídico italiano, por meio da qual é possível fazer uma comparação com o direito brasileiro. Além disso, dispõe de textos de compreensão que vão crescendo gradativamente o nível de dificuldade sendo que tal gradação atende às necessidades dos alunos principiantes".

E- "O livro é muito bom em termos de didática e de conteúdo para aprender a língua italiana relativa à ordem jurídica italiana".

F- "O livro é muito bom para o acompanhamento inicial do italiano, porém pode apresentar algumas imprecisões na matéria de direito".

G- “Top, mas meio básico demais”.

$\mathrm{H}$ - "Adequado em quase sua totalidade, mas contém alguns exercícios noiosos".

I- "O livro, ainda que um pouco confuso quanto a algumas definições, é muito útil para adentrar no campo técnico jurídico".

J- "Muito pouco interessante. Preferiria que a professora nos trouxesse textos jurídicos de verdade: leis, processos, artigos etc. Tive a sensação de estudar um "italiano per giuristi" muito aguado, sem consistência". 
K- "Seu tema específico não é entrave para o aprendizado da língua, ao contrário, incentiva nos estudantes de Direito (pelo menos para mim) o conhecimento das estruturas linguísticas".

L- "Este livro cumpre muito bem com seu propósito na aprendizagem de termos jurídicos em italiano, bem como ensina o básico do direito italiano".

\section{3) Quais suas impressões a respeito do livro Espresso A1?}

A- "Repito, por ser aluno iniciante, ajuda bastante pois começa pelo básico do básico, mas ao mesmo tempo escapa de ser infantil”.

B- "Também considero tal livro apropriado ao seu fim. As lições e os exercícios me pareceram bastante pertinentes, despertando o interesse do aluno ao gradual desenvolvimento de seu aprendizado relativo à língua e à própria cultura italiana".

C- "Apesar de não ter, no momento, base de comparação, pois nunca havia estudado italiano antes, o livro Espresso $A 1$ me pareceu um ótimo livro básico e creio que colaborou para o aprendizado".

D- "Gostei muito dos temas desenvolvidos em cada unidade pois se demonstraram temas úteis a turistas ou pessoas que pretendem fazer cursos na Itália. São temas cotidianos que com certeza serão uteis em eventual viagem à Itália".

E- "É um bom livro de gramática e de lições para aprender o básico da língua italiana. Apresenta bons exercícios e diálogos". 
F- "Muito bom. O livro traz explicações gramaticais claras e atividades uteis para a vida prática".

G- “Traumas...não gosto, mas entendo que é adequado”.

H- "Adequado, embora proponha exercícios de conversação quando o aluno ainda não domina o vocabulário e as expressões linguísticas”.

I- “É um livro prático e simples, sinto falta de aprofundamento em gramática”.

J- "Perfeito para um público iniciante".

K- "Material bom, regular. Cumpriu as expectativas, mas sem impressionar como ocorreu com o Italiano per giuristi”.

L- "Não gostei muito do livro, achei o livro pouco explicativo para o estudo, até mesmo para acompanhar a aula eventualmente perdida".

\section{4) Qual a atividade mais interessante que foi desenvolvida no curso?}

A- "Pesquisas propostas aos colegas sobre termos técnicos específicos sobre o Direito".

B- "Apesar de considera-la um tanto quanto difícil, penso que a atividade de apresentação do seminário foi extremamente interessante, forçando-nos a buscar uma maior evolução em relação ao aprendizado da língua".

C- "O curso como um todo foi interessante, porém destacaria a leitura dos textos jurídicos em italiano".

D- "A atividade mais interessante que foi desenvolvida entendo ser as apresentações, que permitem ao aluno expor um tema jurídico de seu 
interesse na língua recém estudada. É possível notar o progresso no curso".

E- "Gostei do trabalho em grupo que fizemos no início do curso e apresentamos em classe, bem como do seminário".

F- "A atividade mais interessante foi a apresentação dos seminários pelos alunos".

G- "As conversas."

H- "A pesquisa exigida e sua apresentação em sala".

I- "A atividade mais interessante foi ouvir o italiano e compreende-lo sem jamais tê-lo estudado".

J- "Atividade de leitura. Em especial, o início da Constituição Italiana".

K- "O seminário sobre um tema de direito italiano. Permitiu pôr à prova os conhecimentos adquiridos".

L- "As atividades em grupo foram interessantes, ajudaram a treinar pronúncia e conversação, bem como interagir com os outros alunos".

\section{5) Qual a atividade que você considera menos interessante do curso?}

A- "A parte gramatical é a menos interessante, porém não há como fugir dela dada sua importância".

B- "Não considerei nenhuma atividade desnecessária, logo, penso que todas foram interessantes".

C- "Vide resposta acima, o curso foi interessante como um todo, o que se deve ao fato de que todas as atividades desenvolvidas foram pertinentes". 
D- "Não consigo identificar uma atividade menos interessante pois todos os exercícios dos livros adotados permitem o diálogo, a compreensão de textos, a compreensão de áudio e a escrita em italiano".

E- "As atividades menos interessantes são: a realização de exercícios de gramática que poderiam ser feitos em casa e corrigidos pelo aluno".

F- "As atividades menos interessantes são aquelas realizadas em dupla, trio para o exercícios de diálogos em italiano".

G- "A prova, isto é muito século XX".

H- "A gramática. Seria interessante trabalha-la de forma indireta, por meio de frases-modelo, músicas, diálogos de filme, poesia, textos jurídicos".

I- "Não houve atividade menos interessante, a aula fluía muito bem".

J- "O livro Italiano per giuristi como um todo".

K- "As provas! Todas as atividades em sala de aula foram bem desenvolvidas e o seminário muito interessante".

L- "Embora ache interessante ver a apresentação dos colegas, fazê-la já não acho tão interessante assim, não só pela timidez como pouca fluência e domínio da língua".

\section{6) Quais os pontos positivos e os pontos negativos do curso?}

A- "Positivos: preocupação com exercícios auditivos, de pronuncia e de conversação com colegas, interatividade. Negativos: ------“.

B- "Como pontos positivos posso destacar os livros escolhidos e a forma de abordagem da ministrante sempre estimulando-nos a buscar a compreensão mais apurada da língua. Não vejo pontos negativos". 
C- "Os pontos positivos foram: a dedicação da professora e o interesse da turma, o que gerou um bom ambiente e tornou as aulas mais dinâmicas. Não há ponto negativo a ser destacado (vide respostas anteriores)".

D- "Não identifiquei pontos negativos no curso. Dentre os positivos, as aulas são informais, divertidas e cumprem seu papel de passar o conteúdo da língua de forma clara, objetiva e concisa".

E- "Pontos positivos: trabalhos em grupo, exercícios em sala de aula (orais), seminário, apresentação de regras gramaticais, direito italiano. Pontos negativos: exercícios escritos em aula".

F- "Como ponto positivo é possível citar o fato de a professora conseguir fazer a aula aproveitável tanto para alunos básicos quanto para aqueles que já tinham conhecimento prévio da língua. O ponto negativo é a duração do curso. São poucas aulas para um conteúdo longo".

G- "Positivo: tudo. Negativo: o pessoal da secretaria da FFLCH".

H- "Não reconheço pontos negativos que sejam muito relevantes, apesar das críticas no itens anteriores. Os pontos positivos são: trabalho simultâneo da língua com o conteúdo jurídico, leitura em voz alta como correção dos erros de pronúncia, pesquisa extra".

I- "Pontos positivos foram: desenvolvimento da língua italiana, contato direto com o professor devido à classe reduzida, diversificação de conhecimentos. Pontos negativos foram as poucas horas para dedicação mais aprofundada".

J- "As aulas foram um ponto muito positivo, sempre interessante. Gostaria de mais elementos de gramática".

K- Não respondeu. 
L- "Como ponto negativo do curso, tivemos o ingresso de muitos alunos que não estavam mais no nível básico, o que a princípio atrapalhou um pouco os alunos que ainda estavam no nível básico. Como ponto positivo podemos dizer que a professora soube lidar com essa situação, mantendo o curso programado, ou seja, para iniciantes".

\section{7) 0 que contribuiu mais para o desenvolvimento e aproveitamento do} curso: a didática da professora, os livros adotados ou a sua própria dedicação pessoal?

A- "Entendo que predominantemente o conjunto professora + livros, por ser iniciante. Porém, sem dedicação durante as semanas, para relembrar o que foi estudado e treinar, o desenvolvimento ficaria muito prejudicado".

B- "Tanto a didática da professora, quanto os livros adotados contribuíram muito para o bom desenvolvimento do curso".

C- "Sem dúvida foi a conjunção de tais fatores, somada ao método desenvolvido e ao interesse dos alunos".

D- "Acho que o curso poderia ter sido melhor aproveitado se eu tivesse estudado e me dedicado mais às atividades extra classe. Porém, isso não foi influenciado pela didática da professora ou pelo material adotado".

E- "O conjunto desses fatores. Creio que a dedicação pessoal é fundamental para progredir tanto em gramática como em vocabulário e a didática da professora tem grande relevo para o ensino da pronuncia e das regras gramaticais". 
F- "A didática da professora foi fundamental para o aproveitamento, mas acredito que a dedicação pessoal de cada aluno em estudar a língua fora da sala também é essencial".

G- "A união do grupo".

$\mathrm{H}$ - "A abordagem dada pela professora motivou a leitura de material de apoio (constituição, código penal), contribuindo para o aumento do meu vocabulário e o conhecimento do próprio direito italiano (um pouco, é claro)".

I- "Talvez houvesse uma somatória desses fatores. O livro simples aliado ao específico jurídico permite maior interesse. A professora sempre objetiva e hábil consegue atrair os alunos e a dedicação pessoal apenas fixa o conteúdo estudado".

J- "As aulas foram fundamentais, e foco na gramática e uso da língua e os exercícios do livro Espresso A1".

K- Não respondeu.

L- "Meu desenvolvimento e aproveitamento foram devidos à didática da professora, e principalmente pela minha dedicação pessoal".

\section{8) Deixe suas críticas ou sugestões:}

A- Não respondeu.

B- "Como muito dos alunos tem como objetivo utilizar o italiano em seus estudos (necessitando, inclusive, de aprovação em exame de proficiência), seria interessante introduzir uns dois ou três exercícios de tradução, a ser efetuado em sala juntamente com a ministrante". 
C- "Gostaria de parabenizar a professora pela iniciativa, já esperando o início do segundo semestre para prosseguir com o aprendizado".

D- Não respondeu.

E- "Sugestão: programação das atividades a serem feitas em cada aula para que se possa evoluir na gramática e no italiano para juristas de forma conjunta".

F- "O que talvez possa melhorar para o próximo módulo é o aproveitamento do tempo de aula. Algumas vezes notei que o intervalo acabou se estendendo um pouco além do necessário".

G- "Trocar o pessoal da secretaria".

H- "Usar a música no início ou final de todas as aulas".

I- "A minha sugestão seria triar os alunos antes para formar grupos com o mesmo nível de conhecimento a fim de se preparar uma aula específica".

J- "Grazie, professoressa!".

K- Não respondeu.

L- Não respondeu.

\section{Grupo de segunda-feira:}

No grupo de segunda-feira, o número de alunos que realizou a avaliação e concluiu o primeiro módulo foi maior do que o do grupo de sábado. Terminaram o curso dezoito estudantes, e todos foram aprovados, no entanto quatro deles obtiveram a média mínima (7) para poderem frequentar o segundo módulo.

No grupo em questão, observamos uma maior dificuldade na apresentação do seminário. Alguns discentes tiveram dificuldade na leitura do 
texto escolhido para exposição e, a nosso ver, não compreenderam muito bem o texto que escolheram. Notamos isso, pois, ao final de cada apresentação, fazíamos alguma pergunta relacionada ao que haviam apresentado e, por vezes, não conseguiam responder. A pergunta era feita em italiano, mas dávamos a cada aluno a possibilidade de respondê-la em português, pois 0 nosso objetivo era verificar se os aprendizes tinham entendido o texto apresentado. Em alguns casos (três), foi decepcionante, porque, além de realizar uma leitura com muitos erros de pronúncia, o discente não tinha a mínima ideia do que tinha lido. Todas as apresentações dessa turma também foram filmadas e colocamos em anexo alguns trabalhos realizados por eles.

No entanto, considerando que, num grupo de dezoito estudantes, tivemos somente quatro casos problemáticos, podemos afirmar que o resultado foi extremamente positivo, não somente para a professora, mas também para os alunos, como se pode constatar pelas respostas que eles deram ao questionário de avaliação do curso. Tais respostas foram transcritas a seguir. Como já dissemos, as perguntas foram numeradas de 01 a 08, e os aprendizes foram identificados por letras (de A a R). 
1) As suas expectativas iniciais a respeito do curso de Italiano para Juristas foram alcançadas?

A- "Sim, com certeza. Esperava o aprendizado da língua desde o básico, com aprofundamento no vocabulário jurídico e foi isso que tivemos".

B- "Parcialmente, na medida em que esse primeiro módulo teve foco mais nas noções básicas da língua do que em noções básicas jurídicas no direito italiano. Apesar disso, o aprendizado da língua nunca perde ao fixar esse tipo de conceito".

C- "Minhas expectativas iniciais foram alcançadas e superadas no decorrer do curso Italiano para Juristas. Além do conhecimento da língua italiana, o curso me proporcionou conhecimentos de direito que não havia obtido no primeiro ano de graduação".

D- "Sim, mas a parte do italiano jurídico, quanto a textos do Direito Italiano poderia ser mais explorada no 2ํㅡódulo".

E- "Sim, tanto o aprendizado do italiano básico quanto do vocabulário jurídico".

F- "Em grande medida, sim. Talvez o aproveitamento pudesse ser melhor, mas, exclusivamente, em relação à minha própria atuação. $O$ conteúdo do curso esteve de acordo com a proposta e com a expectativa".

G- "Sim, o curso foi ótimo e espero que continue o próximo semestre".

H- "De forma geral sim, consegui alcançar um nível básico de italiano, que era o previsto, desenvolvendo todas as competências, em menor 
parte a escrita, mas de certa forma sim. Talvez o tempo poderia ser melhor planejado a se poder dar o conteúdo mais devagar para se acostumar à língua”.

I- "No início tinha a expectativa de que o curso iria conter muito mais a parte jurídica, mas como sou iniciante em italiano gostei muito do curso ter a parte de gramática e uso da língua italiana".

J- "Minhas expectativas iniciais foram alcançadas".

K- "Sim, pude aprender o nível básico e me interessei pelo Direito Italiano".

L- "Sim, foram superadas principalmente com relação ao curso de italiano".

M- "Sim, o curso começou do básico e foi avançando na matéria de forma bastante satisfatória”.

N- "Sim. Superou as expectativas".

O- "Sim, gostei muito! Apesar do meu foco ser o exame de proficiência, acredito ter sido o curso de grande valia".

P- "Razoavelmente, as aulas são muito lentas e teve pouco conteúdo".

Q- "Sim, pois o curso me trouxe conhecimentos básicos sobre a língua e o ordenamento jurídico italianos".

R- "Sim. Gostei do curso e do material selecionado e do formato das aulas".

\section{2) Qual a sua opinião sobre o livro Italiano per giuristi?}

A- "Muito bom. Simples e com textos interessantes".

B- "Razoável". 
C- "O livro Italiano per giuristi foi muito útil. Traz as informações de modo claro e é de fácil compreensão".

D- "É um bom livro. Não tenho base para comparação pois são poucos livros deste seguimento no mercado".

E- "Livro muito bom para o aprendizado de vocabulário".

F- "Para um primeiro contato com o italiano jurídico é suficiente, mas alguns conteúdos poderiam ser melhorados".

G- "Também gostei muito do livro apesar de ter um pouco de dificuldade".

H- "O livro é muito bom, com exercícios fáceis, porém adequados ao aprendizado".

I- "O livro Italiano per giuristi é interessante principalmente por trazer textos de lei e as explicações do direito na Itália. Porém, os exercícios são simples e normalmente não exigem muito conhecimento do aluno".

J- "O livro é bem completo e apresenta bastante termos jurídicos".

K- "Bom e interessante".

L- "Muito bom, didático e ajuda na compreensão do direito italiano".

M- "Muito bom, apesar de sugerir algumas respostas objetivas que na verdade são mais complexas, mas é excelente para ensinar o vocabulário jurídico".

N- "Achei um bom livro para ter uma ideia global do direito italiano".

O- "Gostei, mas acho que, talvez, poderíamos ter utilizado alguns artigos doutrinários sobre a matéria jurídica".

P- "Bom".

Q- "Exigente na interpretação e conteudista".

R- "Gostei do livro por ser direcionado à iniciação ao Direito italiano". 


\section{3) Quais suas impressões a respeito do livro Espresso A1?}

A- "Gostei bastante. Ele é bem didático - ideal para o aprendizado da língua desde o início".

B- "Bom".

C- "O Espresso A1 é muito bom. Apresenta todo o conteúdo de forma clara e esquematizada. Além disso, as ilustrações auxiliam o entendimento da matéria e a página com o resumo da gramática ao fim de cada unidade ajuda bastante a estudar".

D- "A didática é boa e bem melhor que o livro Linea Diretta que já usei em outro curso de Italiano."

E- "Livro muito bom, bons exercícios de compreensão oral e de gramática, poderia ter mais textos".

F- "Apresenta uma ótima abordagem para o contato inicial com o idioma italiano".

G- "Muito bom e agradável, com bastante vocabulário".

H- "O livro é bem legal, comparado com outros de outros idiomas, diria que são proporcionalmente bons".

I- "Gosto do livro Espresso A1 principalmente nas partes de vocabulário e exercícios, mas acho que o livro não é tão bom na explicação da gramática".

J- "O Espresso parece atender ao ensino do italiano básico".

K- "É um livro bom, mas gostaria que trabalhasse mais na gramática".

L- "Além de didático e ilustrativo, foca na gramática e ajudou bastante no falar e escutar". 
M- "Excelente, didático e metódico".

N- "Gostei bastante".

O- "Gostei! Achei um livro claro e didático".

P- "Bom".

Q- "Bastante didático, de fácil entendimento".

R- "Gostei do livro Espresso A1 por ser prático e fácil em comparação com o livro In Italiano".

\section{4) Qual a atividade mais interessante que foi desenvolvida no curso?}

A- "As apresentações em italiano sobre os temas na área jurídica".

B- "Seminários, face à diversidade das apresentações".

C- "Os seminários foram as atividades mais interessantes, pois via-se diversos assuntos".

D- "O seminário sobre tema jurídico do direito italiano foi muito legal porque fomentou a pesquisa".

E- "Seminários de pesquisa".

F- "As leituras de textos jurídicos em italiano".

G- "Os seminários formam interessantes e despertaram a curiosidade quanto ao italiano jurídico".

H- "Gostava da parte de treinar a pronúncia e desenvolver a competência oral, apesar do nível ser básico".

I- "As atividades mais interessantes foram a explicação da gramática e os diálogos em duplas ou grupos".

J- "As atividades interativas de conversação com os colegas".

K- "Os seminários foram bem interessantes". 
L- "Os seminários ajudaram bastante, na escrita (vocabulário) e fala, foram interessantes, bem como os exercícios do livro".

M- "Apresentação individual sobre um tema em direito a ser pesquisado pelo aluno".

N- "A interação entre alunos e professora fomentando o diálogo em italiano".

O- "As atividades em grupo em sala, salvo os "jogos" do Espresso A1".

P- Não respondeu.

Q- "O conhecimento acerca do ordenamento jurídico italiano".

R- "Todas as atividades foram interessantes: conversação, apresentação de seminário, troca de experiências".

\section{5) Qual a atividade que você considera menos interessante do curso?}

A- "Nenhuma. Toda atividade foi interessante para compor o aprendizado do curso".

B- "Nenhuma".

C- Não respondeu.

D- "Todas as atividades foram importantes (exposição, leitura, exercícios, etc.)."

E- Não respondeu.

F- "As atividades de escuta, provavelmente pela baixa qualidade do som".

G- "Os exercícios e jogos de passatempo não foram muito proveitosos".

$\mathrm{H}$ - "Os seminários de certa forma, pois exige muito do tempo de aula e como se trata de um curso básico, acabou sendo mais uma leitura".

I- Não respondeu.

J- "Considero todas necessárias ao aprendizado da língua". 
K- "Aprendizado de vocabulário".

L- "Talvez exercícios passatempo, mas esses ainda assim eram legais e interessantes".

M- "Acredito que todas as atividades foram importantes".

N- "Prova. Considero desnecessário, acredito que avaliações no curso da aula são mais produtivas".

O- "Os jogos do Espresso A1".

P. "A prova e seminário acho desnecessário, os demais idiomas na FadiUSP lecionados não fazem tal exigência. $O$ aproveitamento deve ser auto-didata e particular".

Q- "Nenhuma".

R- "Todas as atividades foram interessantes e necessárias para 0 aprimoramento do estudo da língua italiana".

6) Quais os pontos positivos e os pontos negativos do curso?

A- "O ponto negativo é que os alunos da turma possuem níveis diferentes, o que às vezes dificulta algumas atividades".

B- "Pontos positivos: material, conhecimento da professora e dedicação da turma. Ponto negativo: horário".

C- "Os pontos positivos são as divisões de assunto antes e depois do intervalo, as remissões e comparações constantes com o direito brasileiro, o modo de se sentar (em círculo) e as leituras em voz alta".

D- "Positivo- ser realizado em um dia por semana. Negativo- sala heterogênea quanto ao domínio do idioma". 
E- "Positivo: uma vez por semana; pesquisa para os seminários; boa didática para o ensino de gramática; bom contato pelo e-mail. Negativo: turma grande; apenas uma prova".

F- "Como pontos positivos: a possibilidade de tomar contato com o idioma italiano juntamente com o italiano jurídico, bem como o conhecimento da professora. Como ponto negativo, a estrutura física da sala não é a mais adequada".

G- "O curso foi muito bom e proveitoso, achei um pouco cansativo 3h de curso no mesmo dia".

$\mathrm{H}$ - "Positivos foram que a profa conseguiu com que todos falassem mesmo com muitos alunos e dominava o assunto, e conseguiu transmitir. Negativo era que poderia ser de forma mais lenta passado o conteúdo, talvez tirando algumas atividades, como os seminários, que por ser nível básico acaba sendo mais uma leitura".

I- "Os pontos positivos são o ensino da língua italiana, pois sou iniciante e achava que o curso versava apenas sobre italiano jurídico, a didática da professora e o conhecimento do Direito italiano. Os pontos negativos são: o livro Espresso A1 falha na parte gramatical e o livro Italiano per giuristi falha nos exercícios".

J- "O único ponto negativo são os exercícios algumas vezes repetitivos e de nível geralmente fácil".

K- "Um ponto positivo é que o curso nos apresentou o italiano jurídico e o ponto negativo é que o tempo foi curto para o aprendizado do nível básico de italiano". 
L- "Positivo a maneira de ensinar e material, negativo seria não ter tanto tempo".

M- "Pontos positivos: aprendi bastante e o ritmo foi muito bom. Pontos negativos: eu preferiria que as aulas começassem 13 horas".

N- "Ponto negativo: durante a tarde. Ponto positivo: possibilitou uma noção ampla de italiano com enfoque jurídico".

O- "Acho que a carga horária poderia ter sido um pouco maior".

P- "Positivo: didática. Negativo: lento".

Q- "De positivo o conhecimento de uma nova língua. O curso não tem pontos negativos".

R- "O curso direcionado para o direito faz a compreensão e o estudo mais fácil. Ótima iniciativa termos um curso para giuristi.

7) O que contribuiu mais para o desenvolvimento e aproveitamento do curso: a didática da professora, os livros adotados ou a sua própria dedicação pessoal?

A- "Os livros são muito interessantes e a professora tem facilidade para ensinar. Acredito que esses dois fatores contribuem bastante".

B- "Os três, bem como a participação de alguns colegas de classe".

C- "Os livros adotados foram muito bons, mas sem dúvida, a didática da professora foi fundamental para o meu desenvolvimento na língua e melhor aproveitamento do curso".

D- "Acredito que os 3 fatores conjugados aos interesses pessoais de cada aluno".

E- "Minha dedicação pessoal e a didática da professora foram muito importantes". 
F- "A didática da professora e os livros, certamente, foram os principais fatores".

G- "Os três contribuíram".

H- "O livro é muito bom, a professora explica bem, porém rápido, e de certa forma a facilidade do idioma para o brasileiro, e o mais prévio conhecimento de outras línguas".

I- "A didática da professora, que explica o uso da língua e a gramática. Os livros adotados são importantes nos exercícios que são feitos em casa".

J- "Todos esses fatores contribuíram igualmente para o aproveitamento do curso".

K- "A didática da professora e minha dedicação".

L- "A didática da professora e os livros".

M- "A didática da professora e os livros adotados".

$\mathrm{N}$ - "Os três elementos fundamentais, no entanto, ressalto o interesse e disponibilidade da professora Quézea que sempre esteve disposta a ajudar".

O- "Os três fatores em conjunto contribuíram: livro bom, professora dedicada e estudo!"

P- "Didática e dedicação".

Q- "A didática da professora e os livros adotados".

R- "Todos os itens apontados contribuíram para o bom desenvolvimento do curso". 


\section{8) Deixe suas críticas ou sugestões:}

A- "Sugiro que façamos mais exercícios de gramática e vocabulário - os do livro talvez não sejam tão suficientes".

B- "Fornecer textos de leitura curtos e didáticos para contribuir no vocabulário".

C- Não respondeu.

D- "Continuar em um dia por semana".

E- "Leitura de mais textos, não necessariamente da área jurídica; vídeos (??); duas provas, ao invés de uma".

F- Não respondeu.

G- Não respondeu.

H- "Limitar os alunos básicos, e não perder aula com prova de verificação de nível, e modificar o esquema dos seminários, para poder dar o conteúdo mais devagar".

I- "Maior ênfase na parte gramatical da língua (sugestão)".

J- "Deve-se melhorar o método de avaliação, os exercícios aplicados, aumentar o número de provas".

K- "O tempo para aprender gramática deveria ser maior".

L- "O curso poderia ter maior duração".

M- "Sugiro que as aulas comecem às 13 horas".

N- "Gostaria que houvessem novas edições desse curso para aqueles que ainda não conheceram e novos módulos para aqueles que estudaram esse semestre".

O- "Como disse acima, gostei e quero continuar no próximo semestre". 

P- "Já respondido".
Q- "A parte gramatical poderia ser mais intensiva".
R- "Continuarmos o curso no próximo semestre".

\section{GRÁFICOS COM AS RESPOSTAS DOS QUESTIONÁRIOS DOS ALUNOS}

\section{Q1- EXPECTATIVAS INICIAIS ALCANÇADAS}

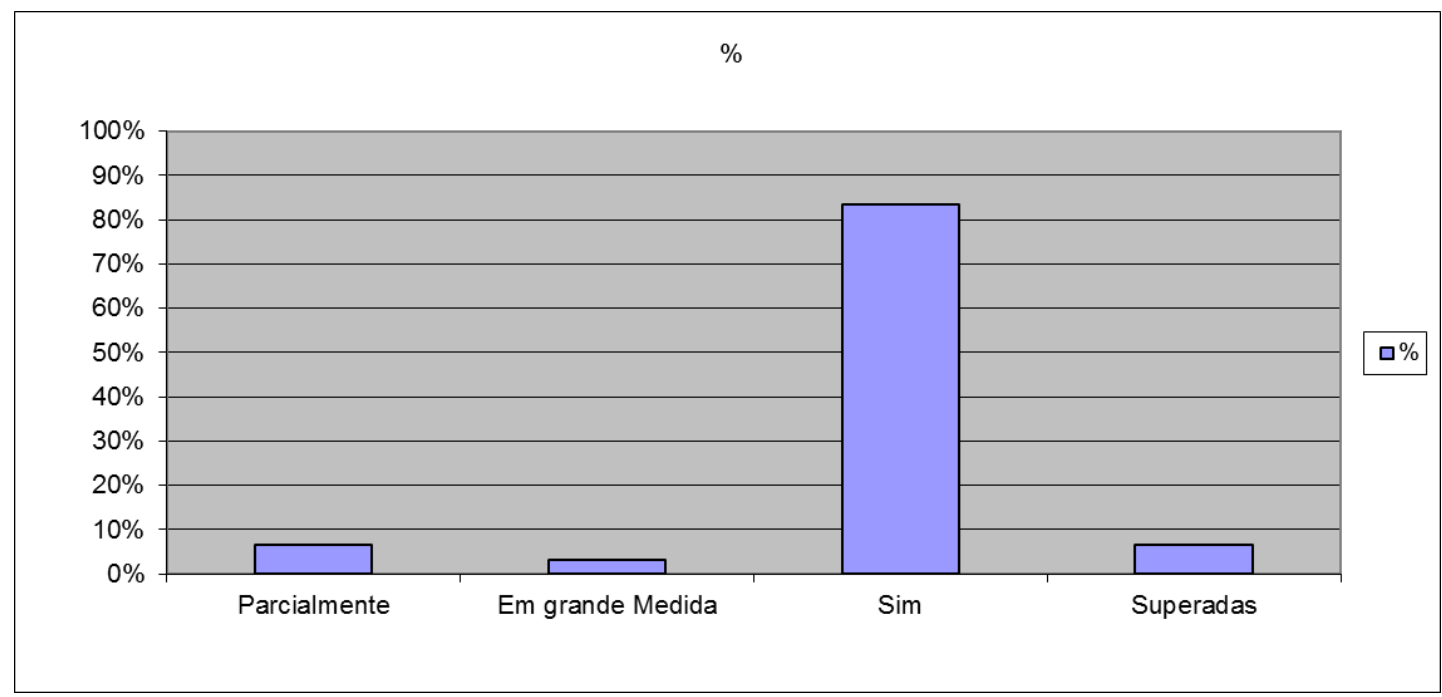

Gráfico 12- Final do primeiro módulo. Expectativas iniciais alcançadas

\section{Q2- OPINIÃO SOBRE O LIVRO ITALIANO PER GIURISTI}

\begin{tabular}{|l|r|r|}
\hline Opiniões & $\begin{array}{c}\text { Número } \\
\text { de } \\
\text { alunos }\end{array}$ & Percentual \\
\hline Muito Básico & 1 & $3,33 \%$ \\
\hline Razoável & 2 & $6,67 \%$ \\
\hline Bom & 10 & $33,33 \%$ \\
\hline Muito Bom & 7 & $23,33 \%$ \\
\hline Suficiente & 1 & $3,33 \%$ \\
\hline Completo & 1 & $3,33 \%$ \\
\hline Gradativo & 1 & $3,33 \%$ \\
\hline Didático & 1 & $3,33 \%$ \\
\hline Adequado & 2 & $6,67 \%$ \\
\hline Interessante & 4 & $13,33 \%$ \\
\hline Agradável & 2 & $6,67 \%$ \\
\hline Exigente & 1 & $3,33 \%$ \\
\hline
\end{tabular}




\begin{tabular}{|l|r|r|} 
Incentivador & 1 & $3,33 \%$ \\
\hline Estrutura do Direito Italiano & 7 & $23,33 \%$ \\
\hline Termos Específicos & 3 & $10,00 \%$ \\
\hline Italiano Jurídico & 1 & $3,33 \%$ \\
\hline Chato & 2 & $6,67 \%$ \\
\hline Sem Consistência & 1 & $3,33 \%$ \\
\hline Impreciso Juridicamente & 2 & $6,67 \%$ \\
\hline Total & 50 & $166,67 \%$ \\
\hline
\end{tabular}

Tabela 1- Opinião sobre o livro Italiano per Giuristi

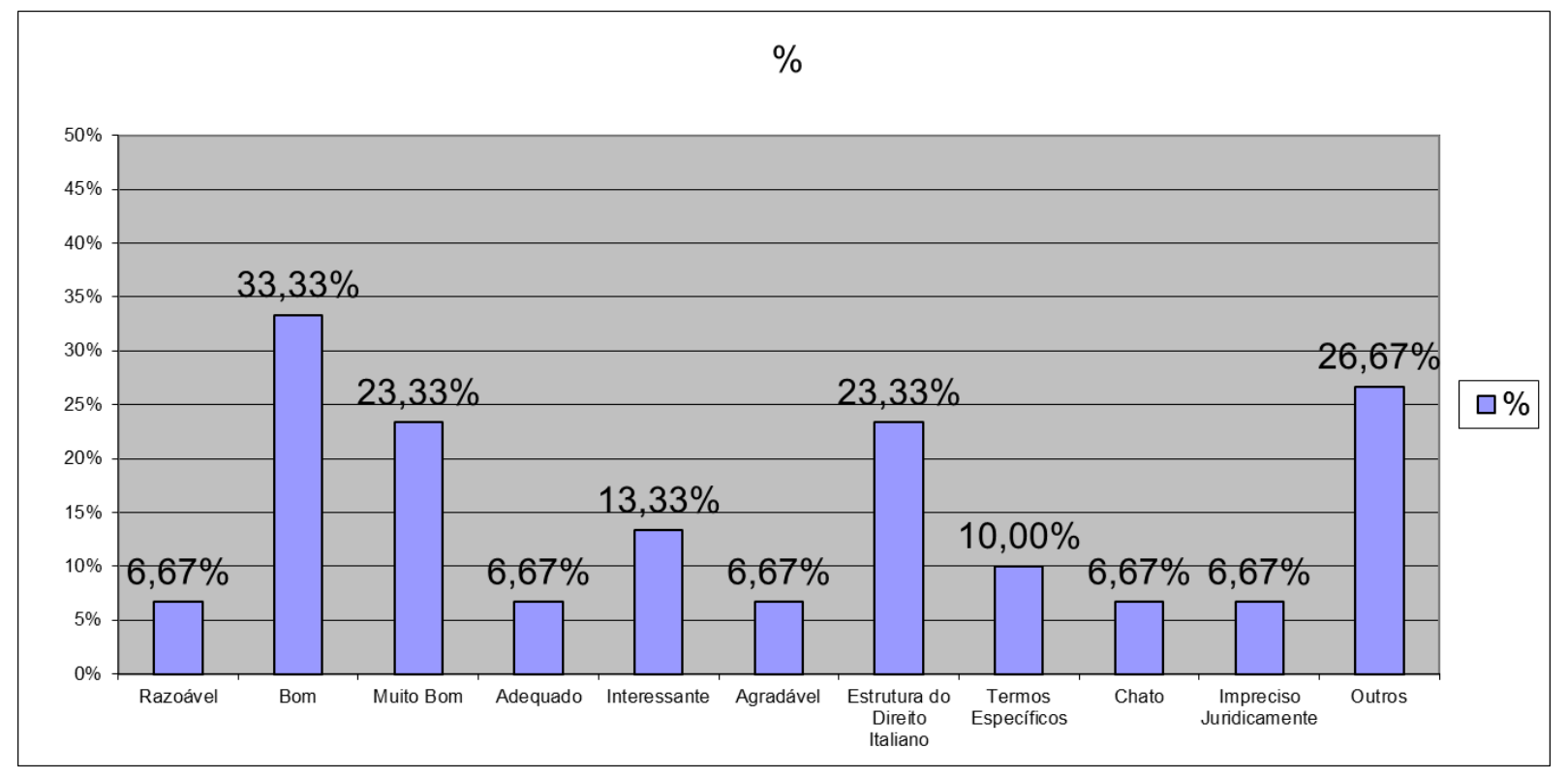

Gráfico 13- Opinião sobre o livro Italiano per giuristi

Q3- IMPRESSÕES A RESPEITO DO LIVRO ESPRESSO A1

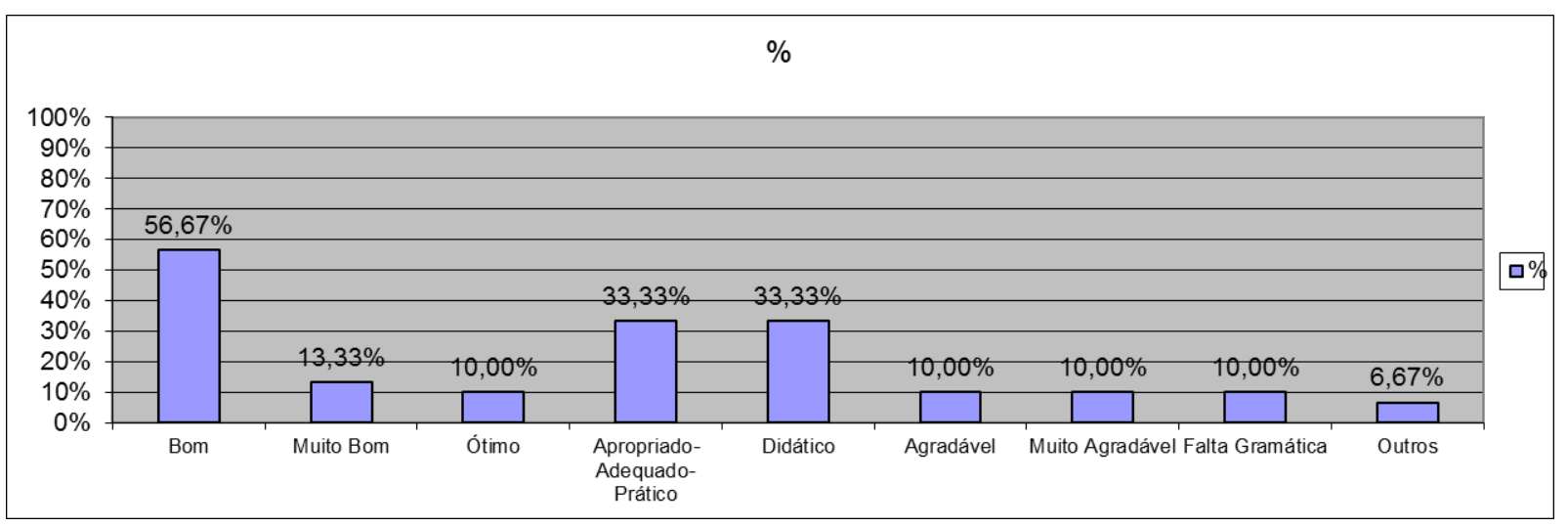

Gráfico 14- Impressões sobre o livro Espresso A1 
Q4 - ATIVIDADE MAIS INTERESSANTE DESENVOLVIDA NO CURSO

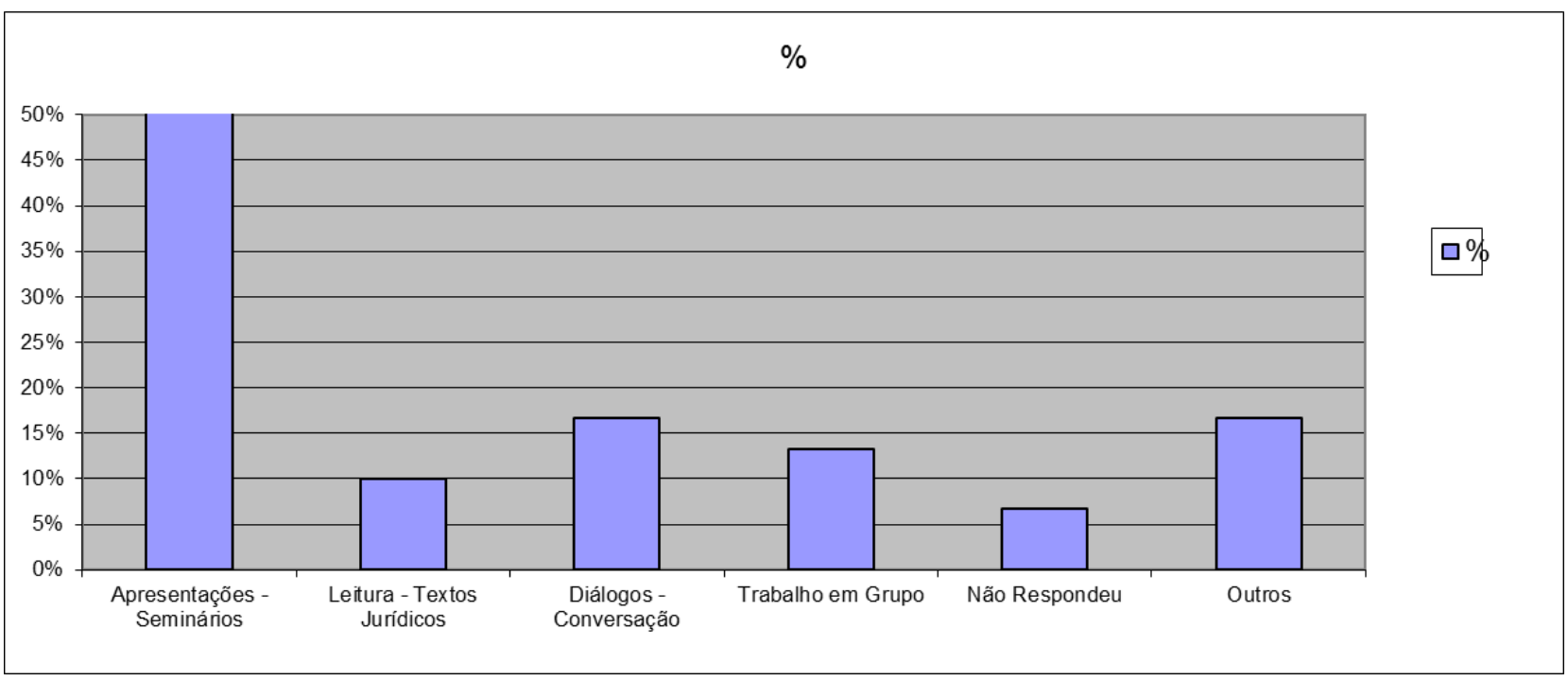

Gráfico 15- Atividade mais interessante do curso

\section{Q5 - ATIVIDADE MENOS INTERESSANTE NO CURSO}

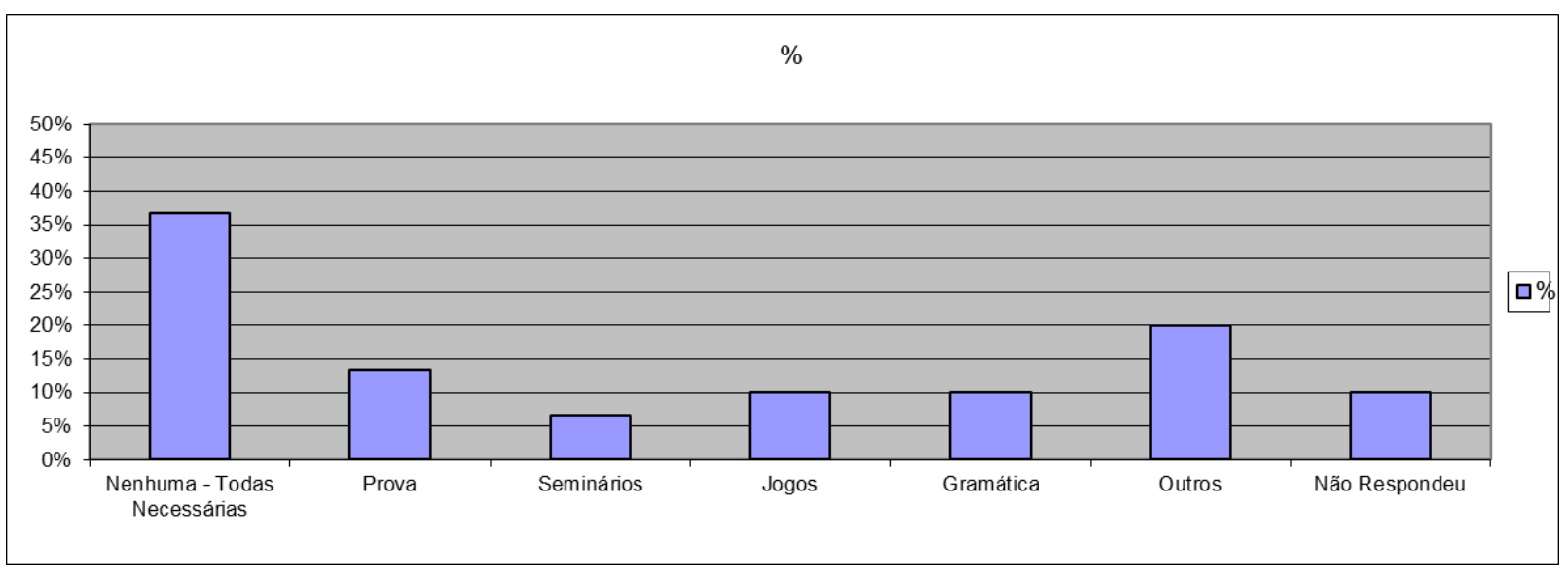

Gráfico 16- Atividade menos interessante do curso 


\section{Q6 - PONTOS POSITIVOS DO CURSO}

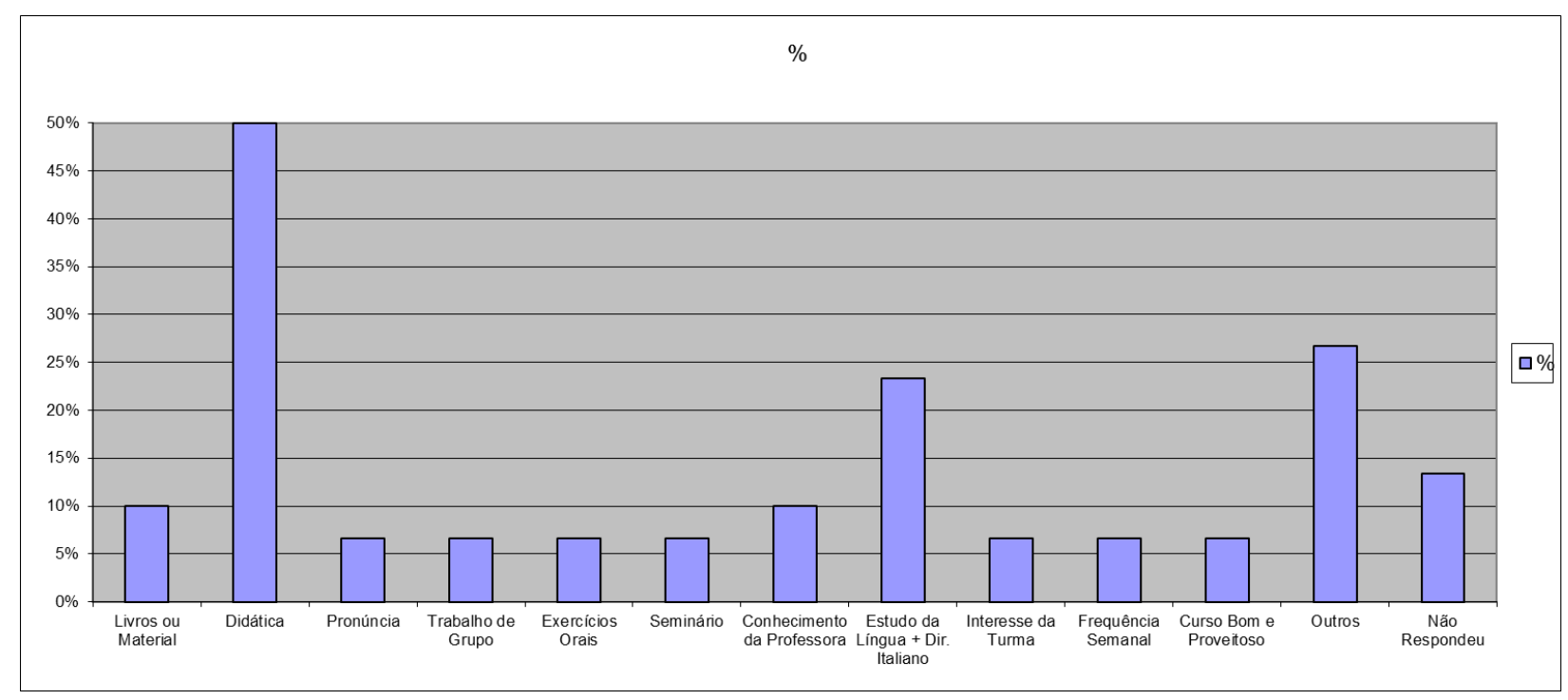

Gráfico 17- Pontos positivos do curso

\section{Q6 - PONTOS NEGATIVOS DO CURSO}

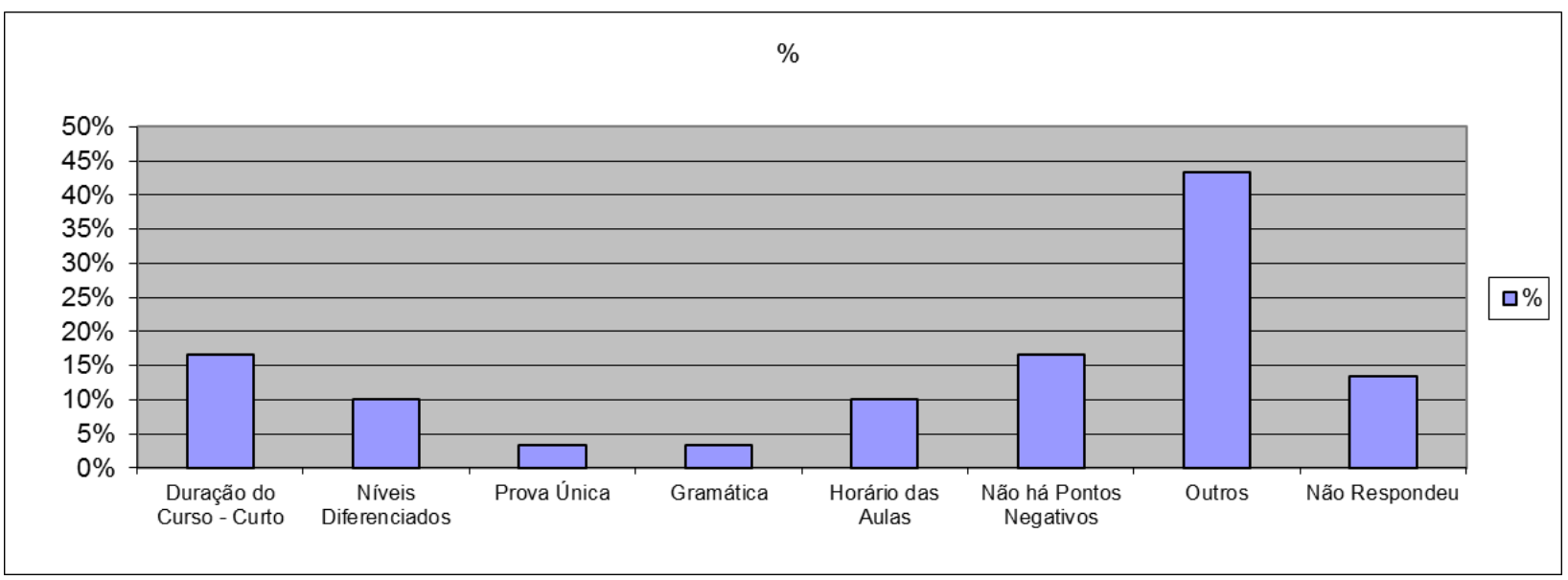

Gráfico 18- Pontos negativos do curso 


\section{Q7 - CONTRIBUIÇÃO PARA O DESENVOLVIMENTO E APROVEITAMENTO DO CURSO}

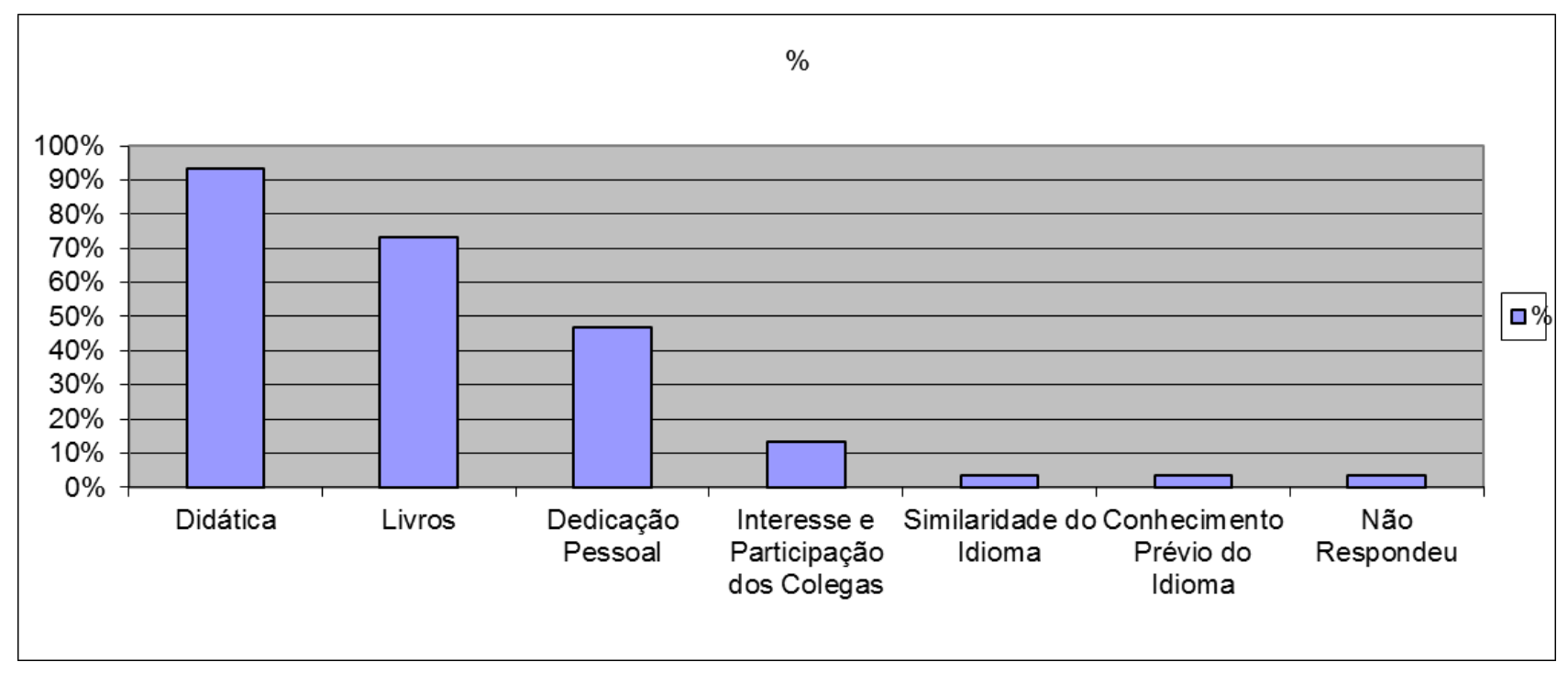

Gráfico 19- Aproveitamento do curso

\section{Q8 - CRÍTICAS OU SUGESTÕES}

\begin{tabular}{|l|c|c|}
\hline Críticas e sugestões & $\begin{array}{c}\text { Número } \\
\text { de } \\
\text { alunos }\end{array}$ & Percentual \\
\hline Mais gramática & 5 & $16,67 \%$ \\
\hline Mais vocabulário & 1 & $3,33 \%$ \\
\hline Seminário - modificar & 1 & $3,33 \%$ \\
\hline Exercícios - melhorar & 1 & $3,33 \%$ \\
\hline Mais Leitura - didática ou jurídica & 2 & $6,67 \%$ \\
\hline Tradução & 1 & $3,33 \%$ \\
\hline Continuidade do curso & 5 & $16,67 \%$ \\
\hline Curso mais longo & 1 & $3,33 \%$ \\
\hline Horário das aulas & 1 & $3,33 \%$ \\
\hline Trocar o pessoal da secretaria & 1 & $3,33 \%$ \\
\hline Novas edições do curso & 1 & $3,33 \%$ \\
\hline Melhorar o método de avaliação & 1 & $3,33 \%$ \\
\hline Mais provas & 1 & $3,33 \%$ \\
\hline Usar Música & 1 & $3,33 \%$ \\
\hline Homogeneidade das turmas & 2 & $6,67 \%$ \\
\hline Intervalo & 1 & $3,33 \%$ \\
\hline Já respondeu anteriormente & 1 & $3,33 \%$ \\
\hline Sem Sugestão & 1 & $3,33 \%$ \\
\hline Não Respondeu & 7 & $23,33 \%$ \\
\hline Total de respondentes & 35 & $116,67 \%$ \\
\hline
\end{tabular}

Tabela 2- Sugestões 


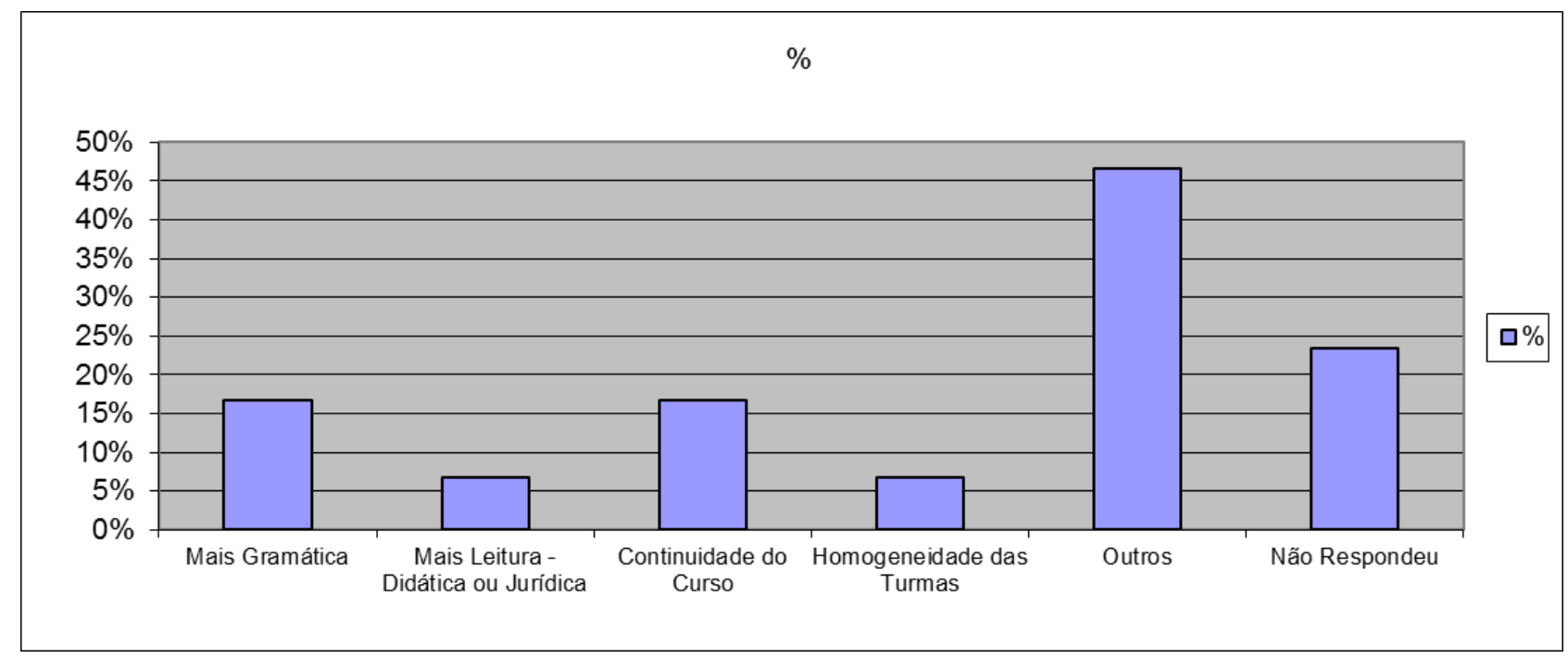

Gráfico 20- Críticas ou sugestões sobre o curso

Pela observação dos gráficos, é possível perceber as opiniões dos aprendizes quanto aos diversos aspectos do curso, por isso não nos parece necessário explicá-las.

No entanto, ao final do primeiro módulo, em junho de 2013, após as avaliações, chegamos às seguintes conclusões preliminares a respeito do desempenho dos alunos:

Em relação à compreensão escrita e oral:

- A maioria dos alunos era capaz de reconhecer palavras e expressões simples, de uso corrente, relativas a si próprios ou à sua família e aos contextos em que estão inseridos.

- Os estudantes conseguiam compreender textos jurídicos escritos simples, relacionados aos assuntos que já dominavam em português.

- Eram capazes de compreender oralmente assuntos jurídicos conhecidos ou assuntos relacionados às necessidades pessoais.

Em relação à produção oral, os discentes eram capazes de: 
- comunicar-se de forma simples, desde que o interlocutor se dispusesse a falar lentamente, a repetir palavras e frases ou reformulá-las;

- utilizar expressões e frases simples para descrever o local onde vivem e pessoas que conhecem.

Em relação à produção escrita, os aprendizes conseguiam:

- escrever um texto simples e breve em um cartão postal;

- preencher fichas com dados pessoais.

Em relação à produção oral, os alunos:

- tinham um repertório básico de palavras e expressões simples relacionadas a aspectos pessoais;

- demonstravam um domínio limitado de estruturas gramaticais e padrões frásicos.

Com relação à coesão de textos escritos e orais, os estudantes conseguiam fazer uso de conectores lineares muito simples, como "e" ou "allora".

\subsection{2- Segundo módulo}

No segundo módulo, a nossa pretensão era trabalhar, sobretudo, a compreensão de textos jurídicos autênticos, no entanto os alunos ainda não tinham conhecimentos gramaticais básicos, isto é, ainda precisavam estudar algumas estruturas linguísticas que Ihes facilitariam a compreensão textual.

Como mencionamos, ao concluirmos o primeiro módulo, tínhamos terminado o trabalho com a quinta unidade do livro Espresso / e, também, com a quinta unidade do Italiano per Giuristi. Descrevemos, a seguir, o nosso 
replanejamento do curso, já que, infelizmente, a nossa programação inicial ficou prejudicada. Quando planejamos o curso, havíamos pensado, em primeiro lugar, em utilizar mais o livro didático Espresso / e, aos poucos, inserir o conteúdo do Italiano per giuristi, porém acabamos empregando os dois manuais contemporaneamente.

A nosso ver, seria necessário um maior empenho no segundo módulo, principalmente por parte dos estudantes, visto que eles precisariam desenvolver, sozinhos, algumas atividades, entre as quais os exercícios de fixação do conteúdo visto em aula, os quais deveriam ser feitos em casa e corrigidos pelo próprio aluno; assim, o tempo da aula seria usado para 0 esclarecimento de dúvidas quanto ao conteúdo estudado na aula anterior e em casa.

No tocante ao conteúdo do Italiano per Giuristi, faríamos as leituras e a compreensão dos textos durante a aula e, principalmente, procuraríamos fazer um debate, de preferência, em italiano. Continuamos, porém, dividindo a aula em duas partes. Na primeira, abordávamos o conteúdo de gramática básica e fazíamos exercícios oralmente para fixar esse conteúdo, usando o Espresso I. Na segunda, abordávamos os assuntos referentes ao Direito, utilizando o livro didático Italiano per giuristi. Queremos salientar que continuamos com os dois grupos de alunos: o de sábado das $10 \mathrm{~h}$ às $13 \mathrm{~h}$, e o de segunda-feira das $14 \mathrm{~h}$ às 17h. Mas, no nosso diário de aulas, unificamos as informações concernentes aos dois grupos, pois seguimos, basicamente, o mesmo planejamento em ambos, e somente algumas atividades foram realizadas de maneira diferente. Seguem as anotações das aulas: 


\section{1a aula}

Comunicação: descrever um lugar, pedir informações sobre um percurso (unidade 6).

Gramática: Uso do ci e do verbo andare.

Léxico específico: Direito Constitucional - Os decretos legislativos (unidade $6)$.

\section{Considerações sobre a aula:}

Primeira parte da aula: fizemos uma pequena revisão de gramática e iniciamos a sexta unidade do Espresso I com o áudio "In giro per l'Italia". Depois, foram realizados exercícios (oralmente) para fixar o uso de c’è e ci sono.

Segunda parte da aula: iniciamos a sexta unidade do Italiano per giuristi, da qual fizemos a leitura do texto sobre a legge delega, que, posteriormente, se tornou decreto legislativo. Os alunos compreenderam, pela leitura do texto, como é elaborada tal lei e fizeram comparações entre esta e o mesmo tipo de lei existente no ordenamento jurídico brasileiro. Essas observações e o debate sobre as diferenças entre o sistema jurídico italiano e o brasileiro eram feitos em italiano ou em português. É importante ressaltar que os alunos já não tinham muita dificuldade para entender os textos do livro Italiano per giuristi: os estudantes conseguiam entender o sentido global de tais textos e tinham apenas algumas dúvidas quanto ao significado de determinadas palavras; durante as leituras, procurávamos esclarecer essas dúvidas.

\section{$2^{a}$ aula}

Comunicação: descrever um percurso; lamentar-se; desculpar-se (unidade 6). 
Gramática: uso dos partitivi no plural; uso de molto como adjetivo e como advérbio; indicações de lugar.

Léxico específico: comparação entre os sistemas - civil law e common law (unidade 7).

\section{Considerações sobre a aula:}

Primeira parte: fizemos a leitura e a compreensão de uma carta e, como tarefa de casa, os alunos deveriam elaborar o texto de um cartão postal ou de uma carta para a aula seguinte. Em seguida, trabalhamos alguns diálogos em que se indicavam percursos, usando o tratamento formal para pedir informações e para explicar o trajeto.

Segunda parte: fizemos a leitura dos textos da sétima unidade do Italiano per Giuristi. O primeiro texto tratava do sistema civil law, sistema jurídico no qual muitos países da Europa se fundam e do qual o sistema jurídico brasileiro se originou. Depois, fizemos a leitura do texto sobre o sistema commom law e comentamos as diferenças e semelhanças entre os dois sistemas.

É importante ressaltar que o nosso exercício de comparação tinha como objetivo praticar a língua, pois sabemos que o trabalho de um comparatista é muito mais profundo e delicado. Para enfrentar o problema que surge da comparação, é necessário ter em mente que o vocabulário jurídico pertence contemporaneamente a um sistema linguístico e a um sistema jurídico dotado de fontes escritas e outras verbalizações. Segundo Sacco (1998) pode acontecer que a terminologia jurídica de um determinado país modele-se de modo a indicar conceitos que descrevam um sistema jurídico semelhante ao do país comparado, porém pode acontecer, também, que o país indicado (na comparação) não tenha a terminologia correspondente e seja necessário fazer 
uma reelaboração linguística inspirada nos dois sistemas para poder transmitir o significado preciso do termo. No que diz respeito à terminologia jurídica italiana e a brasileira, torna-se mais simples o exercício da comparação por serem sistemas afins. Com base nas atividades do livro Italiano per giuristi, visando favorecer a produção oral dos aprendizes, procurávamos incentivá-los a fazerem comparações entre os dois sistemas jurídicos. Esse tipo de exercício de comparação foi realizado em todo o percurso do segundo módulo. Nas primeiras vezes em que fizemos tal atividade, os alunos falaram em português, porque queríamos avaliar a compreensão do texto lido; posteriormente, no entanto, os discentes passaram, aos poucos, a fazer as comparações em italiano, tanto oralmente quanto por escrito.

\section{3a aula}

Comunicação: uso das expressões c'è ...?/ dov'è...? Saber dizer as horas e o horário de funcionamento de lojas e de outros estabelecimentos (unidade 6).

Gramática: verbos dovere, sapere. Advérbios interrogativos: quando, quale.

Léxico específico: Direito Civil - a estrutura do contrato (unidade 8).

\section{Considerações sobre a aula:}

Primeira parte: fizemos um exercício de compreensão oral. Em seguida, fizemos, em pequenos grupos, exercícios orais quanto ao horário de funcionamento dos estabelecimentos comerciais, fazendo uma comparação entre o horário italiano e o brasileiro. A nosso ver, é muito importante propor, sempre que possível, atividades que envolvam diálogos, com o intuito de que os aprendizes exercitem a habilidade comunicativa. Para exercitá-la, faz-se necessário que eles possam dialogar, pois, como ressalta Balboni (2008, p. 50), "aprender uma língua é um ato social". Percebemos que os alunos 
apreciavam esse momento de produção oral, pois se esforçavam para encontrar as palavras corretas e formar frases usando as expressões novas que eram estudadas durante as aulas.

Segunda parte: começamos a unidade 8 do Italiano per Giursti, a qual aborda a estrutura do contrato a partir do artigo 1321 do Código Civil Italiano. Trabalhamos a leitura e a compreensão dos textos "L'accordo fra le parti"; "L'oggetto e il contenuto" e "La causa (e il motivo)". Durante a leitura desses textos, procuramos fazer (oralmente) a comparação entre a estrutura do contrato no Brasil e na Itália. Percebemos que poderíamos exercitar essa comparação, realizando algum trabalho de produção escrita, pois, a estrutura contratual dos dois países são muito semelhantes, e assim, os alunos teriam um tema para desenvolverem a escrita. Na quarta aula, explicamos aos alunos qual a atividade de produção escrita eles iriam desenvolver, trabalho este, que seria feito nas próximas cinco semanas subsequentes.

\section{4⿳a aula}

Comunicação: contar eventos do passado (unidade 7).

Gramática: como é formado o passato prossimo. Uso dos auxiliares essere e avere.

Léxico específico: Direito Civil - a estrutura do contrato (unidade 8).

\section{Considerações sobre a aula:}

Primeira parte: iniciamos a sétima unidade do Espresso I. A primeira atividade desenvolvida foi a compreensão de textos publicitários referentes a viagens; depois, os alunos deviam escolher um dos lugares mostrados em tais publicidades para realizar uma viagem de férias. Concluída essa atividade, os discentes deviam contar sobre as melhores férias que já tiveram. Para que 
pudessem falar sobre elas, explicamos-Ihes o passato prossimo. Os estudantes brasileiros, em geral, têm certa dificuldade para entender o passato prossimo, possivelmente por tratar-se de um tempo verbal composto. Assim, a nosso ver, para que os aprendizes não tenham muitas dúvidas quanto à estrutura e ao uso desse tempo, é preciso que ele seja muito bem trabalhado. Parece-nos que o esquema que fizemos na lousa para explicar a estrutura desse tempo (auxiliar + particípio passado) ajudou os alunos a compreenderem-na melhor. É interessante notar que os discentes que já estudaram francês ou espanhol têm, geralmente, mais facilidade para entender essa construção verbal.

Segunda parte: continuamos a atividade sobre a estrutura do contrato e lemos o texto "La forma", que diz respeito ao último dos requisitos para a formação do contrato e é previsto no artigo 1325 do Código Civil Italiano. A partir da leitura e da compreensão desse artigo, propusemos que os alunos escrevessem um texto em que comparassem os artigos 1325, 1326, 1327, 1328 e 1329 do Código Civil Italiano e os artigos correspondentes no Código Civil Brasileiro. Essa atividade deveria ser desenvolvida da seguinte maneira: após a leitura do artigo em italiano, os estudantes deveriam procurar o artigo correspondente no código brasileiro; ao encontrá-lo, deveriam fazer uma análise dele e apurar quais eram as diferenças entre os dois artigos; por fim, deveriam elaborar, em italiano, um pequeno comentário. Esse trabalho deveria ser desenvolvido nas cinco semanas subsequentes, e os alunos analisariam um artigo por semana. Durante essa aula, os alunos fizeram uma atividade em grupo e, com base nos requisitos vistos sobre a formação dos contratos, elaboraram um contrato simplificado de compra e venda de um imóvel. A seguir, transcrevemos um dos 
contratos produzidos por um grupo de discentes. Ao transcrevê-lo, mantivemos, inclusive, os erros cometidos pelos estudantes.

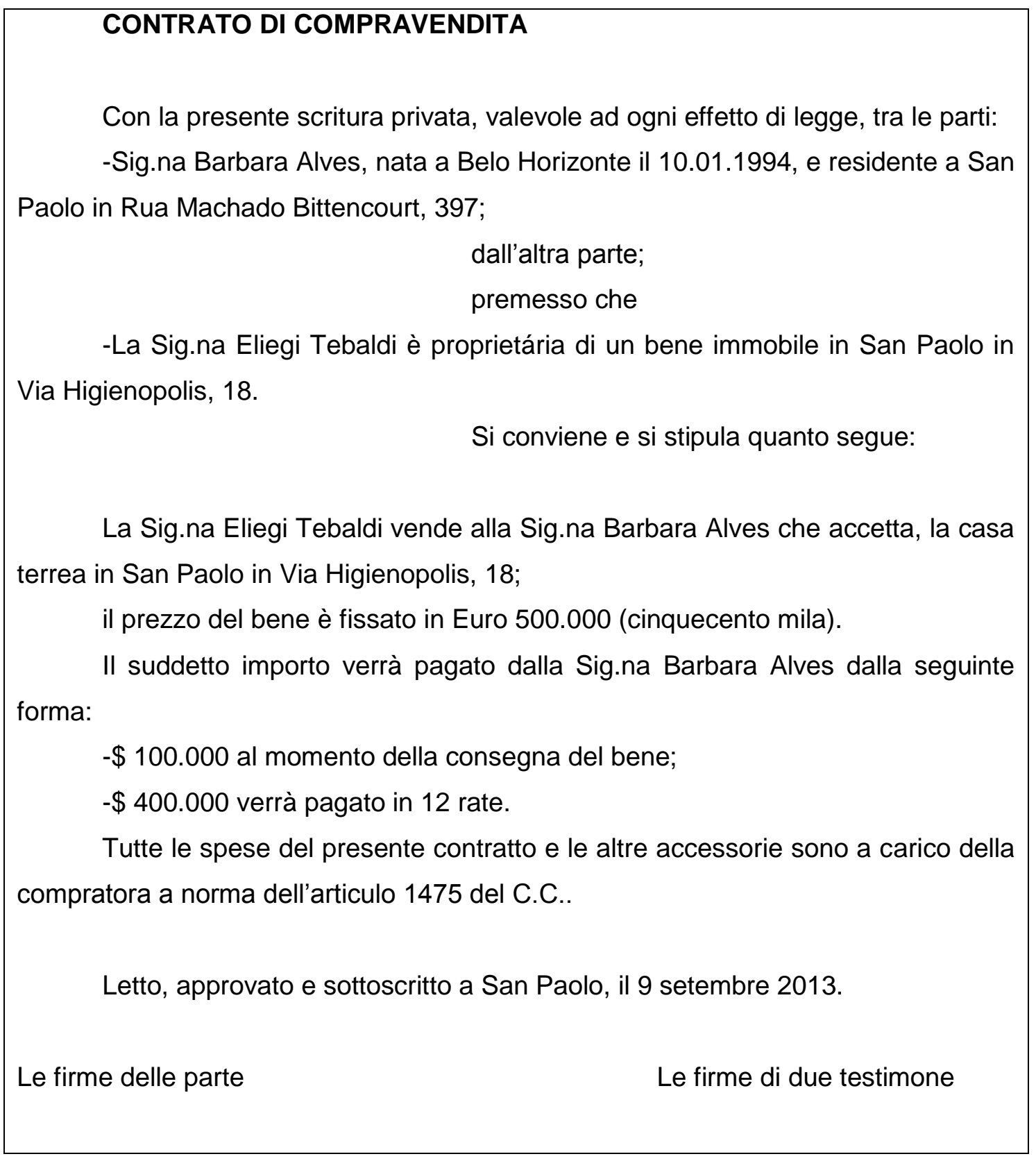

\section{5a aula}

Comunicação: falar sobre as férias; falar sobre o tempo (unidade 7).

Gramática: uso dos particípios regulares e irregulares no passato prossimo.

Léxico específico: Direito Civil - as obrigações (unidade 9). 


\section{Considerações sobre a aula:}

Primeira parte: realizamos atividades para a prática oral dos verbos irregulares. Os alunos, utilizando-se das figuras do manual didático, contaram o que os personagens haviam feito no final de semana.

Segunda parte: fizemos a leitura do texto "Le fonti delle obbligazioni e il rapporto obbligatorio" e, depois disso, resolvemos um caso prático (do próprio livro Italiano per Giuristi) baseado no artigo 1174 do C.C. Italiano.

Como havíamos combinado, os estudantes deveriam entregar o trabalho sobre a comparação entre um artigo italiano e o seu correspondente no Código Civil Brasileiro. É necessário esclarecer que, ao realizarem essa atividade, os alunos faziam um trabalho de Direito Comparado; o nosso objetivo, no entanto, era verificar o uso da língua italiana. O trabalho que transcrevemos a seguir e os que transcrevemos nas páginas subsequentes foram feitos pelos aprendizes. Em cada texto transcrito, mantivemos, inclusive, os erros cometidos pelos alunos.

\section{Trabalho sobre o Artigo 1325 do Código Civil Italiano (C. C. Italiano):}

O discente transcreveu esse artigo e, como correspondente, colocou o artigo 104 do Código Civil Brasileiro (C. C. Brasileiro).

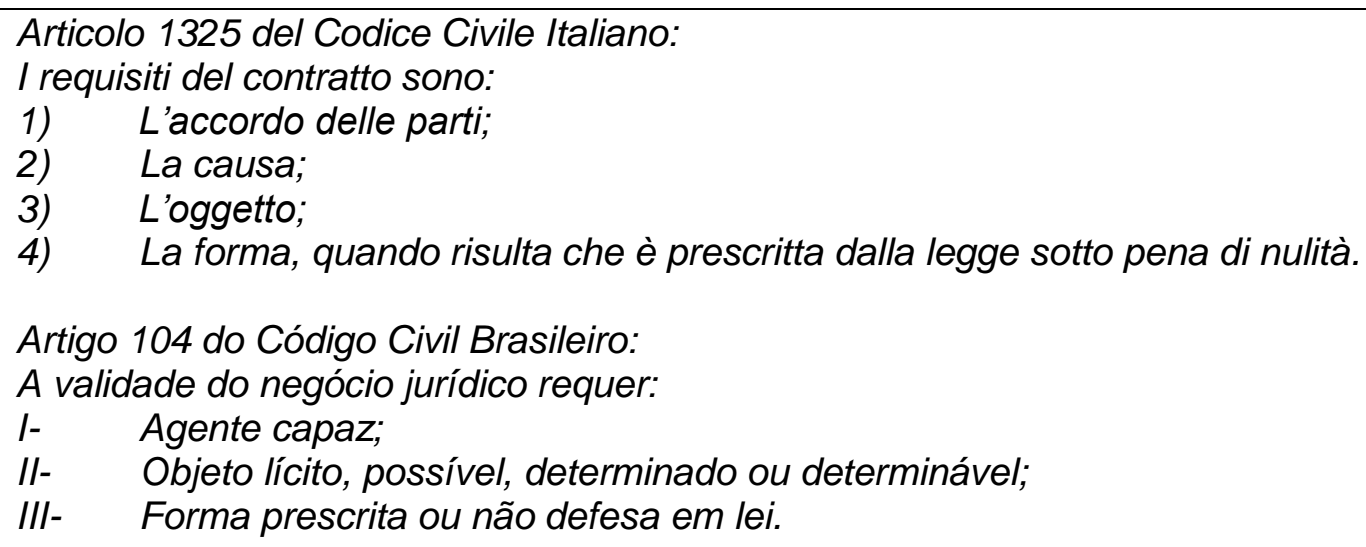

Comentário do aluno: 


II Codice Civile Italiano indica i requisiti specifici dei contratti, mentre il Codice
Brasiliano è più astratto e indica i requisiti che devono essere seguiti per tutti i
negozi giuridici.
II C.C. Italiano si riferi all'accordo delle parti come un requisito dei contratti; il
C.C. Brasiliano omette questo requisito, ma la necessità dell'accordo è facilmente
dedotta da altri articoli et anche dalla dottrina;
II C.C. Brasiliano menziona la capacità delle parti come requisito; si può dire
che questo requisito è incluso nel requisito "l'accordo delle parti" del C.C. Italiano.
II C.C. brasiliano è più preciso nelle sue caratteristiche dell'oggetto del
negozio giuridico: lui deve essere lecitto, possibile, determinato o determinabile; il
C.C. Italiano si riferi semplicemente all'oggetto come requisito.
La forma, nei due Codici; ha la stessa caratteristica; lei può o non essere
prescritta dalla legge; il C.C. Italiano è più completo, perché aggiunge la nullità come
pena si la forma prescritta non è seguita.

\section{6a aula}

Comunicação: contar como passou o fim de semana; o que fez na semana passada (unidade 7).

Gramática: locuções temporais no passado; superlativo absoluto; dupla negação.

Léxico específico: Direito Civil - propriedade, detenção, posse e usucapião (unidade 10).

\section{Considerações sobre a aula:}

Primeira parte da aula: realizamos algumas atividades de compreensão e de produção oral. 
Segunda parte da aula: fizemos a atividade de leitura e compreensão dos textos: "I concetti di proprietà, possesso e detenzione" e "L'usucapione e la regola 'possesso vale titolo'".

\section{Trabalho sobre o Artigo 1326 do C.C. Italiano:}

L'articolo $1326 \mathrm{CCl}$ "Conclusione del contrato" dispone che: "Il contrato è concluso nel momento in cui chi ha fatto la proposta ha conoscenza dell'accettazione dell'altra parte".

Questo può essere comparato con l'articolo 427 del Codice Civile Brasiliano che disciplina "La proposta del contratto obbliga chi ha fatto la proposta, se il contrario non risultare dei condizioni della natura del negozio, o delle circostanze del caso."

L'atra parte dell' articolo italiano non trova somiglianza con nessuno articolo brasiliano, salvo la parte "un accettazione non conforme alla proposta equivale a nuova proposta", che può essere comparato con l'articolo 431 del Codice Civile Brasiliano che regola "la accettazione fuori di tempo con integrazioni, restrizioni, o modifiche equivale a nuova proposta".

\section{$7^{\text {a }}$ aula}

Comunicação: falar sobre fazer compras e sobre os próprios hábitos (unidade 8).

Gramática: pronomes pessoais do caso oblíquo (lo, la, li, le e ne).

Léxico específico: Direito Comercial - tipos de empresas (unidade 11).

Considerações sobre a aula:

Primeira parte da aula: realizamos atividades referentes aos hábitos alimentares, e o primeiro exercício da oitava unidade do Espresso 1 trazia o léxico usado nesse contexto. Depois, fizemos algumas atividades de compreensão oral. Para fixar o conteúdo, foram praticados dois diálogos: "Cosa 
hai comprato?" e "In un negozio". Durante a realização desses diálogos, deixávamos os alunos livres para praticarem-nos; quando percebíamos que tinham terminado a atividade, aproximávamo-nos e pedíamos-lhes que repetissem os diálogos para que pudéssemos fazer a correção dos erros de pronúncia. Após todas essas aulas, os estudantes já conseguiam expressar-se oralmente, utilizando o vocabulário adquirido e sem cometer erros graves.

Segunda parte: iniciamos a leitura da unidade 11 do Italiano per Giuristi e fizemos a atividade de compreensão dos textos "Il linguaggio del codice civile", "Gli articoli 2568 e segg. e l'art. 2571 del Codice Civile".

Trabalho sobre o artigo Artigo 1327 do C.C. Italiano:

L'articolo correspondente all'articolo 1327 del Codice Civile Italiano è l'articolo 432 del Codice Civile brasiliano. L'idea è la stessa, cioè che il contratto è concluso nel tempo e nel luogo in cui ha avuto inizio l'esecuzione prima della risposta dell'accettante.

\section{$8^{\mathbf{a}}$ aula}

Comunicação: falar sobre produtos típicos e como fazer compras em um supermercado (unidade 8).

Gramática: partitivos no singular; advérbios de quantidade.

Léxico específico: Direito Comercial - a s.n.c. (unidade 12).

\section{Considerações sobre a aula:}

Primeira parte: foram praticados os diálogos "Fra negoziante e cliente" e "La lista della spesa", em duplas. Fizemos a atividade de leitura e compreensão do texto "Il posto della pasta". Depois, elaboramos e propusemos aos discentes uma atividade de produção oral intitulada "Il mio negozio preferito". 
Segunda parte: lemos o texto "La società in nome collettivo (s.n.c)". É interessante observar que, na unidade 12, há um exercício em que devem ser completadas as lacunas de um texto intitulado "Atto Costitutivo di una società" e, assim, os alunos puderam entrar em contato com o léxico desse tipo de documento.

\section{Trabalho sobre o Artigo 1328 do C. C. Italiano}

\section{Articolo 1328. Revoca della proposta e dell'accettazione}

La proposta può essere revocata finché il contratto non sia concluso. Tuttavia, se l'accettante ne ha intrapreso in buona fede l'esecuzione prima di avere notizia della revoca, il proponente è tenuto a indennizarlo delle spese e delle perdite subite per l'iniziata esecuzione del contratto.

L' accettazione può essere revocata, purché la revoca giunga a conoscenza del proponente prima dell'accettazione.

L'articolo ricorda l'articolo 429, comma, del Codice Civile Brasiliano:

Art. 429. Parágrafo único. Pode revogar-se a oferta pela mesma via de sua divulgação, desde que ressalvada esta faculdade na oferta realizada.

Benché gli articoli non sono uguali, la dottrina brasiliana capisce la revoca della proposta e dell'accettazione nello stesso modo che l'articolo 1328 del Codice Civile Italiano.

\section{9a aula}

Comunicação: falar sobre hábitos alimentares e dar uma receita de um prato (unidade 8).

Gramática: a forma impessoal (si + verbo).

Léxico específico: Direito Comercial - a s.a.s. (unidade 13).

Considerações sobre a aula: 
Primeira parte da aula: exercício de compreensão oral - "Come si fa il ragù?". Exercício de produção oral: "Qual è il tuo piatto preferito?". Exercício de produção escrita: escrever uma receita de um prato brasileiro em italiano.

Segunda parte da aula: leitura e compreensão do texto: "La società in accomandita semplice (s.a.s.)". Exercício em que deveriam ser completadas as lacunas do texto referente à constituição de uma sociedade: "Costituzione di Società in Accomandita Semplice".

\section{Trabalho sobre o Artigo 1329 do C.C. Italiano:}

\section{Art. 1329- Proposta irrevocabile}

"Se il proponente si è obbligato a mantenere ferma la proposta per un certo tempo, la revoca è senza effetto.

Nell'ipotesi prevista dal comma precedente, la morte o la sopravvenuta incapacità (414) del proponente non toglie efficacia alla proposta, salvo che la natura dell'affare o altre circostanze escludano tale efficacia."

Questo articolo non ha corrispondenza nel Codice Civile Brasiliano. Nel sistema giuridico brasiliano ha la presunzione di irrevocabilità della proposta in qualsiasi negozio giuridico.

$10^{\mathrm{a}}$ aula

Comunicação: falar sobre o horário de trabalho e estudo.

Gramática: verbos reflexivos.

Léxico específico: o processo na Itália (unidade 14).

Considerações sobre a aula:

Primeira parte da aula: iniciamos a unidade 9 do livro Espresso fazendo alguns exercícios de compreensão oral e de produção oral. 
Segunda parte da aula: começamos a trabalhar a unidade 14 do Italiano per Giuristi. Fizemos um exercício de "terminologia per immagini", que visava facilitar a compreensão do processo na Itália por meio do vocabulário mostrado em cada situação exposta. Fizemos, também, a atividade de leitura e compreensão dos seguintes textos: "I gradi del processo", "Il processo civile" e "I giudici nel processo civile".

Nessa aula, propusemos aos estudantes uma atividade de compreensão de um texto autêntico escrito. O texto que escolhemos intitula-se "Diritto e Politica, Metodi e Scuole" e faz parte do livro II Diritto Civile nella legalità costituzionale secondo il sistema Italo-Comunitario delle fonti, escrito por Pietro Perlingieri, docente da Universidade de Camerino (Itália), que é uma instituição renomada pelos trabalhos desenvolvidos na área do Direito Civil Constitucional. Esse livro é muito interessante e passamos a conhecê-lo ao frequentar um curso em tal universidade, no qual tivemos aulas ministradas pelo professor Perlingieri. Foi por esse motivo que selecionamos um texto da obra em questão para trabalharmos com os alunos. Solicitamos-Ihes que fizessem, em casa, pelo menos, três leituras desse texto: na primeira, visava-se à compreensão global; na segunda, os discentes deveriam sublinhar as palavras desconhecidas por eles e procurá-las no dicionário; na terceira, os aprendizes deveriam tomar notas das partes mais importantes do texto e elaborar um resumo, que deveria ser entregue até a última aula.

\section{$11^{\text {a }}$ aula}

Comunicação: falar sobre os próprios hábitos diários e sobre a frequência (unidade 9). 
Gramática: uso das locuções de tempo e de advérbios.

Léxico específico: o processo na Itália (unidade 14).

Considerações sobre a aula:

Primeira parte da aula: usando o Espresso, fizemos algumas atividades de leitura, de produção escrita, de escuta e de produção oral.

Segunda parte da aula: realizamos a atividade de leitura e compreensão dos textos "Il processo penale" e "I giudici nel processo penale".

\section{$12^{\mathrm{a}}$ aula}

Comunicação: descrever e comprar roupas; perguntar o preço (unidade 10).

Gramática: uso dos pronomes pessoais do caso oblíquo.

Léxico específico: o processo penal (unidade 15).

Considerações sobre a aula:

Primeira parte da aula: iniciamos a unidade 10 do livro didático, na qual foram feitas atividades para trabalharmos as quatro habilidades primárias.

Segunda parte da aula: começamos a décima quinta unidade do Italiano per giuristi, que aborda o processo penal na Itália utilizando-se do recurso "terminologia per immagini", que, como dissemos anteriormente, facilita muito a compreensão e memorização dos termos relativos ao processo. Depois, fizemos a leitura do texto "Le fasi preliminari del processo penale".

\section{$13^{\mathrm{a}}$ aula}

Comunicação: exprimir gostos e mostrar indecisão; fazer comparações (unidade 10).

Gramática: comparativos e diminutivos. 
Léxico específico: o processo penal (unidade 15).

\section{Considerações sobre a aula:}

Primeira parte da aula: fizemos um exercício de compreensão escrita, um de compreensão oral, um de produção escrita e um de produção oral.

Segunda parte da aula: realizamos a atividade de leitura e compreensão do texto "Svolgimento del processo penale".

\section{4ํaa aula}

Considerações sobre a aula: terminamos, na aula anterior, o conteúdo dos dois livros didáticos (Italiano per Giuristi e Espresso 1), por isso, fizemos uma revisão do conteúdo gramatical visto nas unidades do Espresso 1.

Em nossa décima quarta aula, os alunos fizeram-nos muitas perguntas quanto ao trabalho que eles deveriam fazer com base no texto do professor Perlingieri. Por isso, propusemos-lhes a seguinte atividade: dividimos a classe em três grupos e dividimos o texto em três partes; cada grupo deveria ler e discutir a parte do texto que Ihe foi atribuída; a discussão poderia ser feita em português ou em italiano, pois, nessa atividade, o objetivo principal consistia no desenvolvimento da compreensão escrita, e não no da produção oral; concluída essa discussão, cada grupo deveria apresentar suas observações à classe. Alguns estudantes fizeram comentários em italiano acerca do texto, mas a maioria preferiu falar em português. Foi muito satisfatório ver o resultado do debate feito pelos discentes, pois notamos que eles tinham compreendido muito bem a ideia do autor, e, portanto, nosso escopo foi atingido. 
$15^{\mathrm{a}}$ aula

Considerações sobre a aula: com o objetivo de avaliarmos a compreensão escrita e a produção escrita dos alunos, elaboramos uma prova, que foi aplicada em nossa décima quinta aula. Mostramos, a seguir, a avaliação que preparamos:

\section{VALUTAZIONE}

\section{CORSO DI ITALIANO PER GIURISTI 2 LIVELLO}

ALUNNO:

DATA:

LEGGERE IL TESTO E RISPONDERE ALLE DOMANDE:

VIOLENZA SULLE DONNE

\section{In Gazzetta la legge sul femminicidio}

È stata pubblicata sulla "Gazzetta Ufficiale" del 15 ottobre 2013 n. 242 la legge 15 ottobre 2013 n. 119 conversione in legge, con modificazioni, del decretolegge 14 agosto 2013 n. 93, recante disposizioni urgenti in materia di sicurezza e per il contrasto della violenza di genere, nonché in tema di protezione civile e di commissariamento delle province. L'entrata in vigore del provvedimento è fissata per il 16 ottobre 2013.

Ecco alcune delle principali novità in relazione al contrasto alla violenza sulle donne.

\section{Relazione affettiva}

È il nuovo parametro su cui tarare aggravanti e misure di prevenzione. Rilevante sotto il profilo penale è da ora in poi la relazione tra due persone a prescindere da convivenza o vincolo matrimoniale (attuale o pregresso). II codice si arricchisce di una nuova aggravante comune applicabile al maltrattamento in famiglia e a tutti i reati di violenza fisica commessi in danno o in presenza di minorenni o in danno di donne incinte. Quanto all'aggravante dello stalking commesso dal coniuge, viene 
meno la condizione che vi sia separazione legale o divorzio. Aggravanti specifiche, inoltre, sono previste nel caso di violenza sessuale contro donne in gravidanza o commessa dal coniuge (anche separato o divorziato) o da chi sia o sia stato legato da relazione affettiva.

\section{Querela a doppio binario}

II dilemma revocabilità/irrevocabilità della querela nel reato di stalking è sciolto fissando una soglia di rischio: se si è in presenza di gravi minacce ripetute, ad esempio con armi, la querela diventa irrevocabile. Resta revocabile invece negli altri casi, ma la remissione può essere fatta solo in sede processuale davanti all'autorità giudiziaria, e ciò al fine di garantire (non certo di comprimere) la libera determinazione e consapevolezza della vittima.

\section{Ammonimento}

Il questore in presenza di percosse o lesioni (considerati 'reati sentinella') può ammonire il responsabile aggiungendo anche la sospensione della patente da parte del prefetto. Si estende cioè alla violenza domestica una misura preventiva già prevista per lo stalking. Non sono ammesse segnalazioni anonime, ma è garantita la segretezza delle generalità del segnalante. L'ammonito deve essere informato dal questore sui centri di recupero e servizi sociali disponibili sul territorio.

\section{Arresto obbligatorio}

In caso di flagranza, l'arresto sarà obbligatorio anche nei reati di maltrattamenti in famiglia e stalking.

\section{Allontanamento urgente da casa}

Al di fuori dell'arresto obbligatorio, la polizia giudiziaria se autorizzata dal Pm e se ricorre la flagranza di gravi reati (tra cui lesioni gravi, minaccia aggravata e violenze), può applicare la misura pre-cautelare dell'allontanamento d'urgenza dalla casa familiare e del divieto di avvicinamento ai luoghi frequentati dalla persona offesa.

\section{Braccialetto elettronico e intercettazioni}

Chi è allontanato dalla casa familiare potrà essere controllato attraverso il braccialetto elettronico o altri strumenti elettronici. Nel caso di atti persecutori, inoltre, sarà possibile ricorrere alle intercettazioni telefoniche. 


\section{Obblighi di informazione}

A tutela della persona offesa scatta in sede processuale una serie di obblighi di comunicazione in linea con la direttiva europea sulla protezione delle vittime di reato. La persona offesa, ad esempio, dovrà essere informata della facoltà di nomina di un difensore e di tutto ciò che attiene alla applicazione o modifica di misure cautelari o coercitive nei confronti dell'imputato in reati di violenza alla persona.

Fonte: http://www.diritto24.ilsole24ore.com/guidaAIDiritto/penale/novitaNormative/2013/10/in-gazzettala-legge-sul-femminicidio.html

\section{DOMANDE:}

1) Quali sono state le principali novità riguardo alla legge di cui tratta il testo?

2) Per quanto riguarda le relazioni affettive quali sono le aggravanti?

3) Che cosa ha capito sulla querela a doppio binario?

4) In quale occasione il questore può fare l'ammonimento?

5) Quando l'arresto è obbligatorio?

6) L'allontanamento urgente da casa deve essere autorizzato da chi?

7) Come può essere controllata la persona che si trova allontanata da casa?

8) Quali sono gli obblighi di informazione?

9) Quali sono le differenze di questa legge e della legge brasiliana (Maria da Penha)?

10) E le somiglianze? Quali sono?

Cabe observar, aqui, que essa avaliação foi realizada de maneiras diferentes nos dois grupos. O grupo de sábado estava bastante reduzido, com somente quatro alunos, por isso foi-Ihes possível exercitar bastante a produção oral; no entanto, como os aprendizes dessa turma não tinham muito tempo para fazer os trabalhos escritos (que deveriam ser feitos fora das aulas), ficaram prejudicados no tocante à produção escrita. O grupo de segunda-feira, por sua vez, pôde desenvolver melhor essa habilidade. Por esse motivo, 
acreditamos que seria mais proveitoso realizarmos a avaliação de formas diversas nas duas turmas.

Com o grupo de segunda-feira, fizemos uma leitura in plenum e, em seguida, esclarecemos todas as dúvidas que os aprendizes tinham quanto ao vocabulário utilizado no texto. Após a leitura, cada um deles deveria fazer, em italiano, um comentário sobre a lei. Foi gratificante ver que todos os alunos conseguiram expressar-se muito bem em italiano e fizeram comentários muito coerentes com o texto lido. Em seguida, responderam as questões, por escrito.

Já no grupo de sábado, entregamos o texto aos estudantes e dissemosIhes que, durante a leitura, se quisessem, poderiam utilizar o dicionário para procurar as palavras cujo significado eles desconheciam; além disso, não lhes esclarecemos nenhuma dúvida.

A seguir, transcrevemos as respostas de alguns dos alunos (com os erros) do grupo de sábado:

1) Quali sono state le principali novità riguardo alla legge di cui tratta il testo?

Le principali novità sono la relazione affetiva, che è il nuovo parametro, e le misure di prevenzione. Per la nuova legge, la relazione affetiva esclude la convivenza e il vincolo matrimoniale come necessari al reato.

2) Per quanto riguarda le relazioni affettive quali sono le aggravanti? Le aggravanti sono il maltrattamento in famiglia, in presenza di minorenni o in danno di donne incinte. Ci sono ancora aggravanti specifiche nel caso di violenza sessuale contro donne in gravidanza e da chi sia in relazione affetiva. 
3) Che cosa ha capito sulla querela a doppio binario?

La querela può essere revocata, meno nel caso di gravi minacce ripetute, quando diventa irrevocabile. Inoltre, la remissione deve essere fatta unicamente in sede processuale al fine di garantire la libera determinazione della vittima.

4) In quale occasione il questore può fare l'ammonimento? Il questore può fare l'ammonimento in presenza di percosse o lesioni.

5) Quando l'arresto è obbligatorio?

L'arresto sarà obbligatorio in caso di flagranza.

6) L'allontanamento urgente da casa deve essere autorizzato da chi? C'è il PM chi autorizza l'allontanamento.

7) Come può essere controllata la persona che si trova allontanata da casa?

Questa persona può essere controlatta attraverso il braccialetto elettronico o altri strumenti elettronici.

8) Quali sono gli obblighi di informazione?

La persona offesa dovrà essere informata di tutto ciò che attiene alla applicazione o modifica di misure cautelari o coercitivi nei confronti dell'imputato in reati di violenza alla persona.

9) Quali sono le differenze tra questa legge e la legge brasiliana (Maria da Penha)?

Nella legge brasiliana non c'è il controllo attraverso il braccialetto elettronico o altri strumenti elettronici, e non ci sono le aggravanti applicabile ai reati di violenza fisica comessi in danno o in presenza di minorenni o in danno di donne incinte. 
Observação: As perguntas 9 e 10, na verdade, exigiam que os aprendizes tivessem um profundo conhecimento da Lei Maria da Penha, e esse não era o caso da maior parte deles, pois poucos estudantes trabalham na área penal. As respostas transcritas acima foram elaboradas por um aluno que é especialista em Direito Penal. Apesar de ambas serem questões referentes ao Direito Comparado (que exigiam, portanto, conhecimentos específicos), quisemos somente avaliar como os discentes responderiam uma pergunta cuja resposta não se encontrava no texto, o que exigia deles a mobilização de conhecimentos prévios e a reflexão sobre as leis mencionadas.

10) E le somiglianze? Quali sono?

Le somiglianze sono tre, basicamente. Primo l'oggetto della legge- la violenza di genere; dopo la misura pre-cautelare dell'allontanamento d'urgenza e l'obblighi di informazione.

\section{6 aula}

Como havíamos programado, os alunos entregaram-nos um resumo do texto do professor Pietro Perlingieri. Abaixo, transcrevemos dois resumos: um em italiano, e outro em português.

\section{1) Resumo em italiano:}

\section{“Diritto, giudici e politica" - riassunto}

1- Inquietudini del civilista contemporaneo.

Il civilista ha il dovere di introdurre alle scienze giuridiche, ma, contemporaneamente, questo è un compito molto complesso. Questa complessità ha molte ragione: il diritto non si riduce ai concetti e alle categorie generale; la tradizionale distinzione tra il diritto pubblico e privato è diventata incerta; il diritto non 
si separa della ideologia, né della politica; la società e la legislazione cambiano rapido; le fonti giuriche sono varie e molto complesse.

Infatti, ci sono state molte trasformazione dopo la Costituzione Italiana di 1947: riforme negli anni 60, 70 e 80, anche della Costituzione. Con la globalizzazione economica e la crisi della statalità del diritto, un problema si presenta: la crisi della legalità e della normatività. Quindi, la scienza giuridica deve si domandare si lo studio del diritto si può fare senza inserirsi nella realtà sociale e giuridica, nella discussione sull'organizzazione dello Stato e dei servizi sociali.

\section{2- Scienza giuridica e cultura giuridica}

La scienza giuridica insegnata ai nuovi studenti non può essere totalmente allontanata della prassi. All'inverso, il giurista deve avere la consapevolezza che il diritto si costruisce su una base storica, e non da verità fisse; un'ordinamento giuridico è sempre l'ordinamento di una società, che ha i suoi problemi e che pensa i soluzioni. Quindi, conoscere i concetti, le legge e interpretarle non è sufficiente. Solo si può capire il sistema con la sua applicazione ai problemi della realtà. Dunque, l'interpretazione giurisprudenziale è molto importante, perché confronta il sistema normativa con i fatti.

\section{3- $\quad$ Filosofi e civilisti a confronto: la filosofia nel diritto}

Nel diritto, i soggetti (ogni centro d'imputazione soggetive, sia le persone umane, sia le persone giuridiche) si confrontano con la norma. Infatti, la norma solo può essere compresa in un rapporto con i fatti, con la storia e con la società. II diritto e la norma esistano esattamente perché gli individui vivono in società e, quindi, il dialogo tra il fiolosofo ed il civilista è necessario. Così si può conoscere meglio le radici dell'ordinamento giuridico e e si può dare senso all'attività del giurista e anche alla stessa scienza giuridica.

La contribuzione dei filosofi deve essere rinvenire la filosofia che fondamenta l'odinamento giuridico vigente, perché questa filosofia può aiutare nel compito dell'interpretazione giuridica. La Costituzione Italiana è il risultato di un'attento studio filosofico; questa ispirazione può essere scoperta con l'analisi degli atti dell'Assemblea costituente e delle persone che vi hanno partecipato. È molto importante il lavoro di trovare la filosofia nel diritto.

Lo studio dell'ordinamento giuridico deve sempre tenere presente il momento storico-giuridico e anche storico-politico. Per esempio, la pluralità delle fonti del diritto nell'ordinamento italiano deve essere interpretata come una trasformzione 
nella concezione della norma. Questo tipo di analisi sarebbe il lavoro del filosofo, che deve analizzare i fondamenti, i principi dell'ordinamento.

4- $\quad$ Finalità pratiche della scienza giuridica e educazione del giurista

Come scienza pratica, il diritto ha bisogno di confrontare norma e fatto; tuttavia, questo confronto è storicamente definito e può cambiare secondo qualche variabile: la definizione di norma; le fonti giuridiche; la gerarchia delle norme; il valore della giurisprudenza, ecc. Tutti quelli che applicano il diritto hanno strumenti di conoscenza della norma e del fatto; quegli strumenti sono un'analise minuziosa del fatto, ma, principalmente, una conoscenza ampia dell'ordinamento, che considera la sua interdisicplinarità con altre scienze sociali. Quindi, l'educazione del giurista è essenziale: lui deve conoscere la realtà e deve essere sensibile nell'interpretare e nell'applicare le norme.

5- Interpretazioni unilaterali della giuridicità: il particolarismo come forza degenerativa del pluralismo

È essenziale che l'interpretazione del diritto non sia « «politicista», cioè, il politico non può si sovraporre al giuridico. Quindi, il giurista non deve svolgere la sua attività secondo le sue preferenze, non può fare una lettura soggetiva e strumentale delle norme; all'inverso, deve conoscere l'ordinamento e utilizzarlo nella società secondo la legge. La legalità e l' "ingegneria costituzionale" sono in crisi quando i conflitti di interessi sono risolti a traverso un gioco irrazionale delle forze contrarie, cioè, quando la soluzione non è oggetiva.

6- Crisi dello Stato sociale di diritto

Lo Stato sociale de diritto presupone due forme di libertà: la libertà negativa, dallo Stato (lo Stato ha il dovere di rispettare qualche diritto individuali) e la liberta positiva, libertà mediante lo Stato (lo Stato ha il dovere di prestare servizi ai cittadini perché loro possano svilupparsi pienamente). L'ordinamento italiano configura un avanzato Stato sociale, perché ha molta importanza la realizzazione di diritti sociali (diritto allo studio, alla cultura, ecc) e della detta solidarietà, che significa una redistribuzione. Tuttavia, si può dire che questo Stato sociale è in crisi: c'è un incremento della burocrazia, molta corruzione ed abuso di potere. I grandi problemi sono il particolarismo e l'egoismo.

C'è anche un problema culturale dello Stato di diritto: interpretazioni antitetiche della Costituzione si confrontano, ma né una, né l'altra seguono esattamente la strada indicata dal costituente

7- Centralità della "questione giudiziaria"

Il funzionamento interno del potere giudiziaria è un grande problema oggi. I 
processi sono molto lenti e i principi inseganti nelle aule universitarie non sono totalmente presenti nella realtà degli operatori del diritto.

\title{
Vocabolario:
}

Sfociare - concludersi, risolversi in qlco (=resultar)

Spinta - stimolo, incentivo (=incentivo)

Rinsaldare - rendere qlco. più saldo, più tenace; rafforzare (=reforçar)

Fungere - servire da (=servir de)

Rinvenire - recuperare, scoprire (=descobrir)

Scorgere - comprendere, scoprire (=compreender)

Schiacciata - deformato in seguito a compressione (=esmagado)

Smarrito - che non si trova più, perduto (=perdido)

\section{2) Resumo em português:}

\begin{abstract}
Capitolo primo: DIRITTO GIUDICI E POLITICA
Inquietudini del civilista contemporaneo.

Neste ponto inicial o autor faz uma reflexão acerca das "inquietudes" do civilista contemporâneo enfatizando a difícil tarefa de como iniciar os estudos jurídicos que por vezes se restringem aos estudos de conceitos amplos e históricos; as meras distinções entre direitos público e privado; a incindibilidade do direito e política enquanto ciências sociais; as rápidas mudanças sociais quanto aos valores fundamentais da ciência jurídica; dos costumes; do estilo de vida e até mesmo da pluralidade das fontes jurídicas e sua complexidade. Desta forma o autor nos apresenta esta rápida e intensa evolução através de uma digressão histórica da legislação italiana e os fatos históricos e sociais relacionados a ela: a crise do liberalismo e capitalismo; após isso, salienta as reformas constitucionais dos anos 60 e 70 vem a forma degenerativa do pluralismo (em que o autor faz uma referencia especial à obra de PERLINGIERI); já nos anos 90 e 2000 a legislação claramente se mostrou com influências comunitárias e no plano constitucional com clara influencia federalista, já se contrastando com a globalização da economia e a própria crise de estabilidade do direito. Por fim o autor aponta questionamentos sobre a crise do direito e em especial, do direito civil e de se é possível falar em direito civil sem pensar nas problemáticas da organização do estado e dos serviços sociais.
\end{abstract}




\begin{abstract}
Scienza giuridica e cultura giuridica.
Neste ponto o autor chama a atenção para a dificuldade do ensino do direito nas universidades e o quanto se distancia do direito praticado nos tribunais e na própria vida (se referindo às relações sociais). Portanto aponta que se deve ter coragem para ensinar e buscar o direito crítico e a capacidade argumentativa, que é essencial ao jurista. A cultura jurídica não pode se basear nos meros dogmas jurídicos e verdades fixas. O direito também é cultura de uma sociedade, as sínteses dos problemas sociais e suas soluções ou um universo de possíveis soluções. A cultura jurídica seria então o fruto da atividade interpretativa feita pelos operadores do direito, não bastando, portanto, o mero confronto com os fatos ou a realidade social ou até mesmo com os problemas concretos. E necessário conhecer esses fatos e para tanto, o autor aponta que é necessário por em confronto o sistema normativo com a realidade dos fatos, da ciência e da praxe.
\end{abstract}

\title{
Filosofi e civilisti a confronto: la filosofia nel diritto.
}

Neste tópico o autor chama a atenção para uma discussão muito interessante acerca do confronto entre filósofos e civilistas. Os quatros termos: sujeitos (no plural) e norma (no singular), indivíduo e sociedade configuram uma problemática unitária e esta seria a razão em si do próprio direito. Ele argumenta ainda que a norma não pode ser compreendida fora da sociedade e a contrario senso a sociedade civil não pode ser valorada apartando-se da norma. O encontro entre o filosofo do direito e o civilista é necessário e não apenas como ocorre frequentemente entre filósofos e penalistas. Portanto é necessário fortalecer esse dialogo sem, é claro, que cada lado perca sua identidade.

E necessário compreender qual tipo de filosofia está presente no ordenamento vigente e exemplifica isso com a Constituição italiana que é fruto de muitas leituras de filosofia.

Salienta também que a teoria do ordenamento jurídico deve corresponder ao momento histórico-jurídico e ao vigente principio de legalidade.

\section{Finalità pratiche della scienza giuridica e educazione del giurista.}

Neste trecho o autor nos convida à reflexão sobre a finalidade pratica da ciência jurídica e a educação do jurista quanto à sua formação. O Direito como ciência possui inúmeras variáveis, como a hierarquia entre as normas, regras sobre 
autonomia privada e negocial, etc. Destaca ainda a importância das práticas legais na atividade do jurista e que não deve se valer de instrumentos predeterminados e rígidos, mas que deve se valer de uma cultura ampla e de um conhecimento global do ordenamento. O ponto alto do discurso do autor esta no fato de enfatizar a importância da interdisciplinaridade dentro do ordenamento jurídico, lembrando que a interdisciplinaridade no âmbito do ordenamento não pode ser considerada separadamente da interdisciplinaridade do direito com outras ciências sociais. Essa continuidade não pode ser garantida senão pelo substrato cultural e pela educação do jurista. Finaliza com o argumento de que é necessário que o jurista tenha sensibilidade ao interpretar, conhecendo a realidade e individualizando as normas a serem aplicadas.

Interpretazione unilaterali della giuridicità: il particolarismo come forza degenerativa del pluralismo.

O autor aponta sobre a prejudicialidade das interpretações dotadas do que chama de "particularismos" versus pluralismo; ou seja, as interpretações unilaterais feitas pelos juristas são inadequadas. As contradições e os conflitos de interesses necessitam inspirar-se num critério jurídico de seleção e graduação.

\section{Crisi dello Stato sociale di diritto.}

A abordagem neste tópico é muito interessante, quanto ao fato do autor abordar as nuances do Estado social de direito, com as liberdades negativas e positivas, destacando que não é suficiente que o Estado se abstenha de comportamentos invasivos das liberdades individuais, mas que haja ações asseguradoras desse efetivo exercício das liberdades. Portanto a crise, apontada pelo autor, é na realidade a cultura sobre a qual se funda o Estado de direito - a crise perdida culturalmente pelo senso civil da legalidade e da justiça. Portanto, o Estado social deve construir seus direitos e seus deveres sociais.

\section{Centralità della "questione giudiziaria".}

A centralidade da questão judiciária, de que trata o autor, se concentra no debate em torno da questão judiciária, as suas conexões diante da vagarosidade do julgamento dos processos, a ruptura entre os princípios que são ensinados nas aulas universitárias e a realidade cotidiana vista pelos operadores práticos do direito e pelos usuários do serviço judiciário. Por fim, enfatiza que a aproximação entre os 


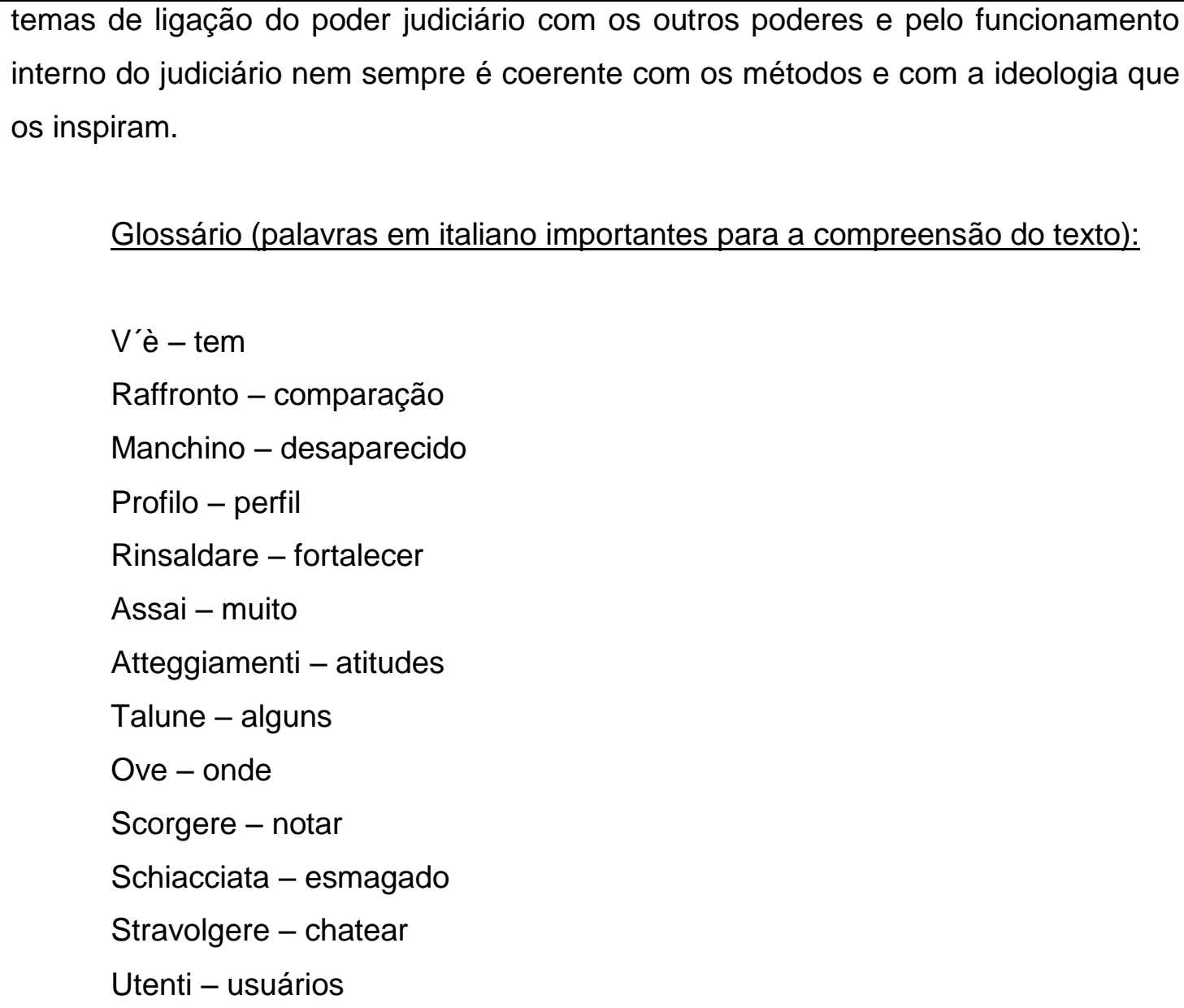

Glossário (palavras em italiano importantes para a compreensão do texto):

V'è - tem

Raffronto - comparação

Manchino - desaparecido

Profilo - perfil

Rinsaldare - fortalecer

Assai - muito

Atteggiamenti - atitudes

Talune - alguns

Ove - onde

Scorgere - notar

Schiacciata - esmagado

Stravolgere - chatear

Utenti - usuários

Os alunos que se inscreveram no curso com o objetivo de se prepararem para o exame de proficiência em língua italiana fizeram o resumo em português, pois essa era uma maneira de exercitar o que lhes seria exigido em tal prova. Foi também por esse motivo que demos aos estudantes a opção de fazer o resumo em português ou em italiano.

Nessa aula, aplicamos uma prova para avaliar a compreensão oral e a produção oral. Encontramos, na internet, vários vídeos de aulas de Direito para o ensino médio na Itália. Escolhemos e mostramos aos discentes um vídeo intitulado "Os três poderes do Estado - O pensamento de Montesquieu"45. Inicialmente, havíamos planejado que o vídeo seria reproduzido, no máximo,

${ }^{45}$ Vídeo disponível em: https://www.youtube.com/watch?v=ceE4rKw0Ytg. Acesso em: 16 de outubro de 2013. 
três vezes, mas, por causa da má qualidade da acústica da sala, foi necessário mostrá-lo mais uma vez; portanto, ele foi visto pelos alunos quatro vezes. Nas duas primeiras, pretendíamos que os aprendizes tivessem uma compreensão global do assunto tratado; nas outras duas, eles deveriam, com base no vídeo, tentar responder algumas perguntas.

As três primeiras questões deveriam ser respondidas oralmente e, quando os alunos estivessem respondendo, seriam filmados por nós. No entanto, cada estudante deveria escolher apenas uma pergunta para responder no momento da filmagem. Decidimos somente filmar uma resposta, porque os discentes ficam, em geral, muito inibidos ao saberem que estão sendo filmados. Ao analisar os vídeos com as respostas dos estudantes, foi interessante observar que os alunos utilizaram as expressões que ouviram no decorrer da explicação sobre a teoria dos Três Poderes. Pudemos perceber que os discentes conseguiram compreender e reproduzir o léxico que tinham acabado de escutar. A atividade em que os alunos mais tiveram dúvidas foi a última, na qual avaliávamos a aplicação de regras gramaticais (referentes ao uso dos artigos e das preposições). Percebemos que, no que concerne à compreensão do texto oral, os aprendizes tiveram um bom desempenho; contudo, no tocante aos exercícios gramaticais, tiveram dificuldades. A seguir, mostramos a prova que elaboramos e aplicamos: 


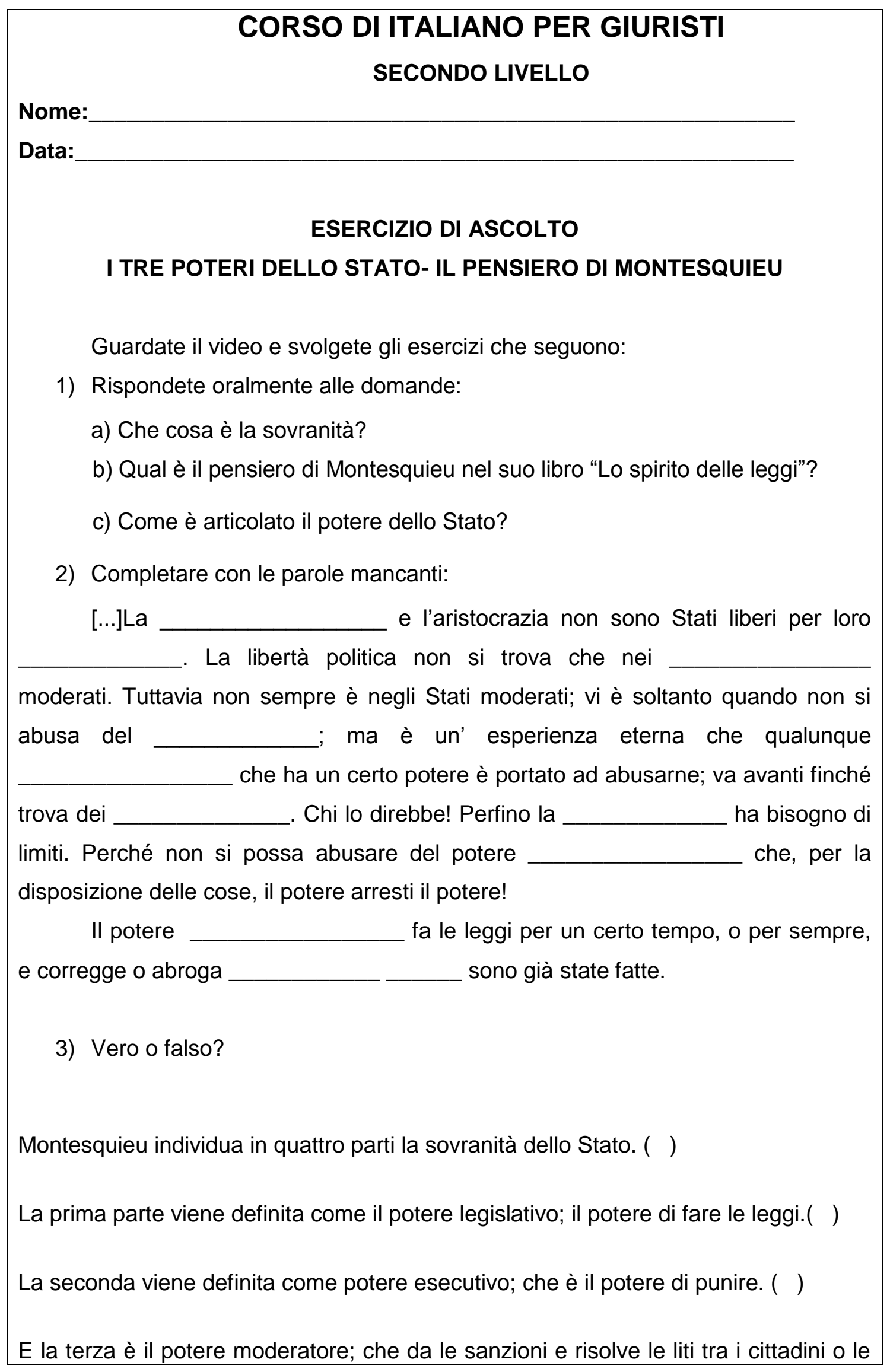




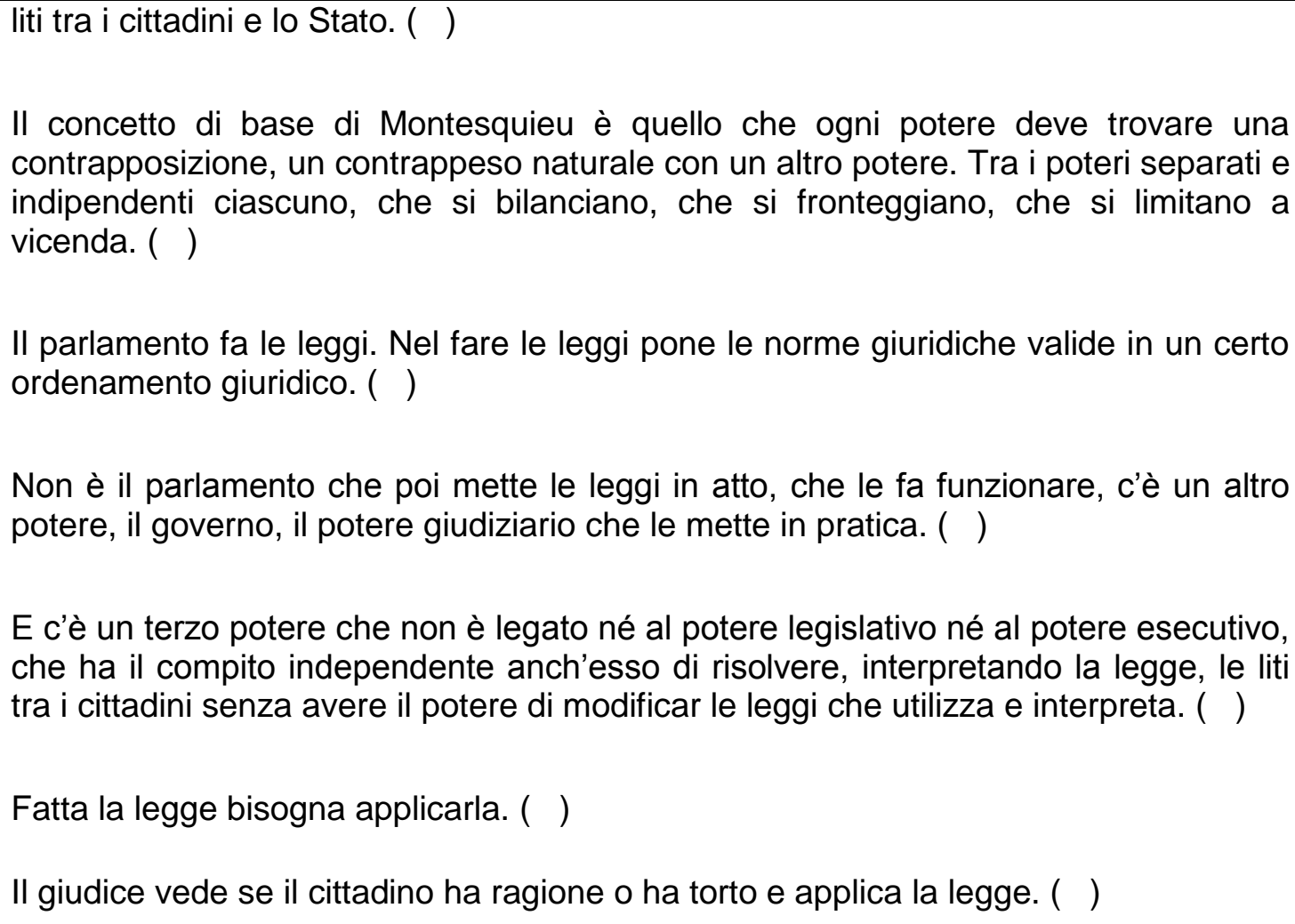

Non è il parlamento che poi mette le leggi in atto, che le fa funzionare, c'è un altro potere, il governo, il potere giudiziario che le mette in pratica. ( )

E c'è un terzo potere che non è legato né al potere legislativo né al potere esecutivo, che ha il compito independente anch'esso di risolvere, interpretando la legge, le liti tra i cittadini senza avere il potere di modificar le leggi che utilizza e interpreta. ( )

Fatta la legge bisogna applicarla. ( )

Il giudice vede se il cittadino ha ragione o ha torto e applica la legge. ( )

4) Completa con gli articoli e con le preposizioni che mancano:

È chiaro che se giudice potesse fare anche legge, ogni caso troverebbe una risposta che qualche maneira lui adatta sue leggi e non alla legge data potere legislativo. Allo stesso modo il potere esecutivo, attuare, nel mettere in pratica legge, se non lo fa con dovuta correttezza, con il dovuto rispetto norma, potrebbe cambiarsi la norma, se potesse fare lui stessa legge, adattandola a ciò che sta facendo non essendo più obbligato rispettare la legge. $\mathrm{E}$ così il potere legislativo non può risolvere liti perché se il potere legislativo potesse risolvere le liti, anche qui, risolvere le liti facendo anche giudice, potrebbe addattare la legge sua esigenza di quel momento. Quindi i tre poteri, legislativo, esecutivo e giudiziario, ciascuno independente altro e ciascuno che si bilancia l'altro, si espande, poiché un certo potere portato ad abusare va avanti finché trova limiti, va avanti fino a che trova limite dell'altro potere.[...] 
$\mathrm{Na}$ última aula, os aprendizes responderam um questionário ${ }^{46}$ referente ao desenvolvimento do curso e ao desempenho deles nas aulas. A seguir, mostramos os gráficos com as respostas dos estudantes:

\section{Gráficos do questionário respondido pelos alunos no final do segundo módulo:}

\section{Q1- Nota de 0 a 5 quanto ao desempenho dos discentes no curso}

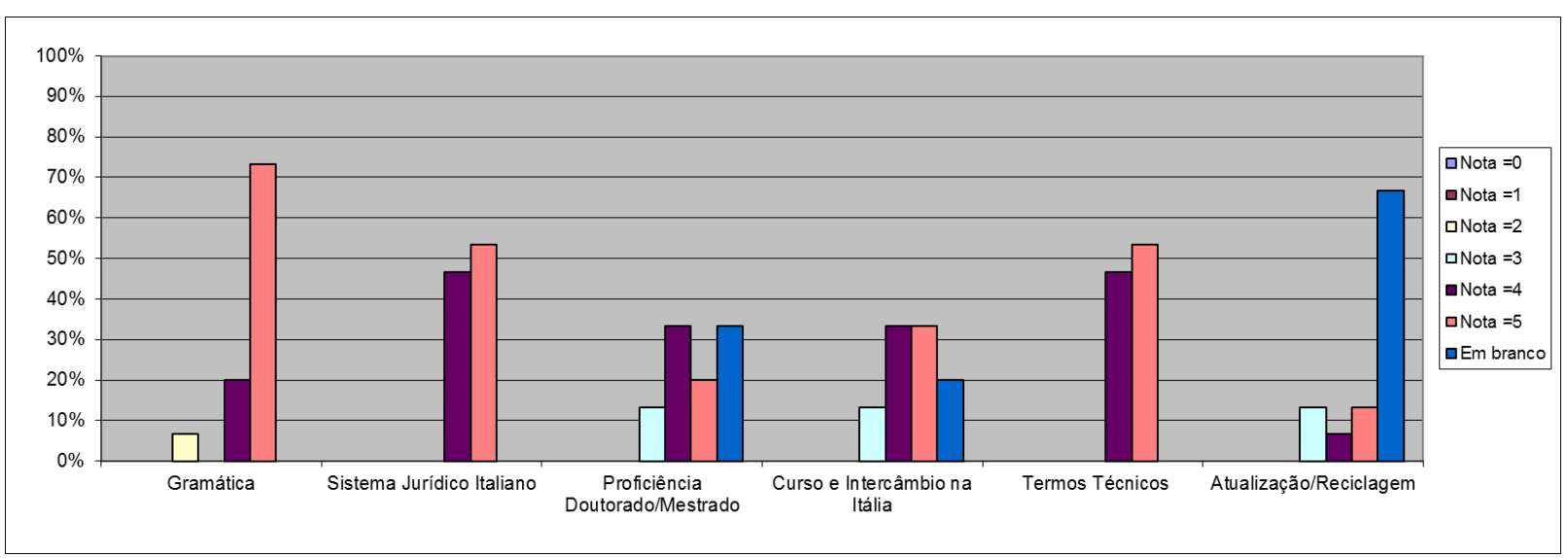

Gráfico 21- Nota dos alunos quanto ao próprio desempenho no curso

Q2- Aspecto em que os alunos alcançaram maior nível

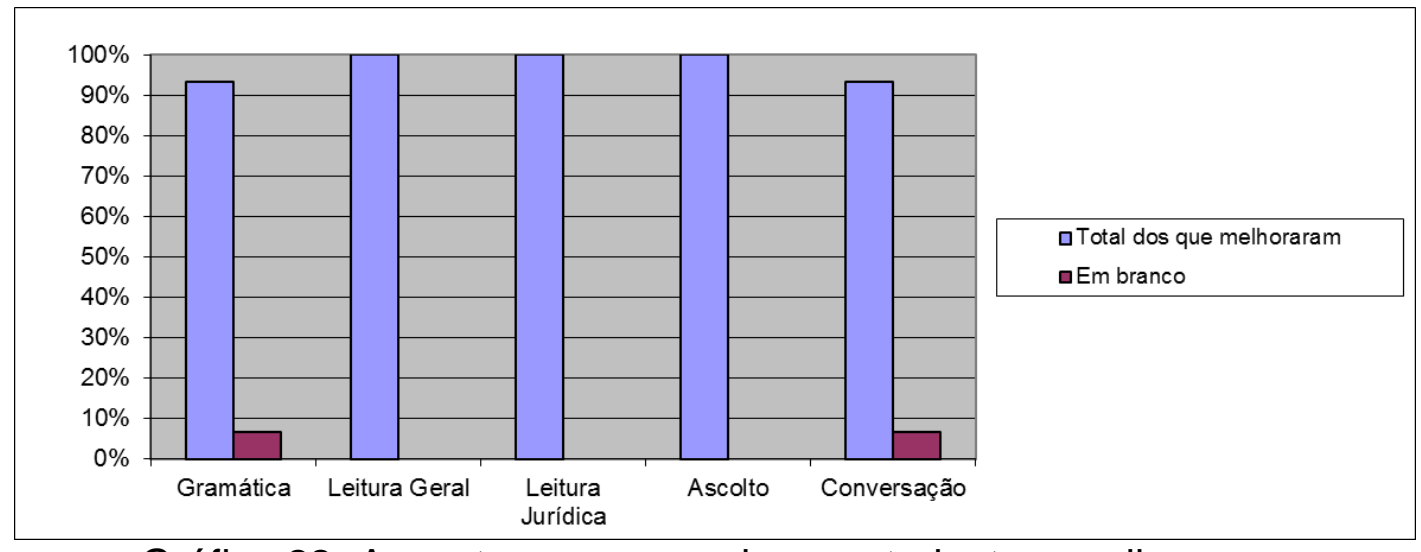

Gráfico 22- Aspecto que, segundo os estudantes, melhorou

${ }^{46}$ O questionário completo está no apêndice. 


\section{Q3- O que poderia ser mais bem trabalhado durante o curso?}

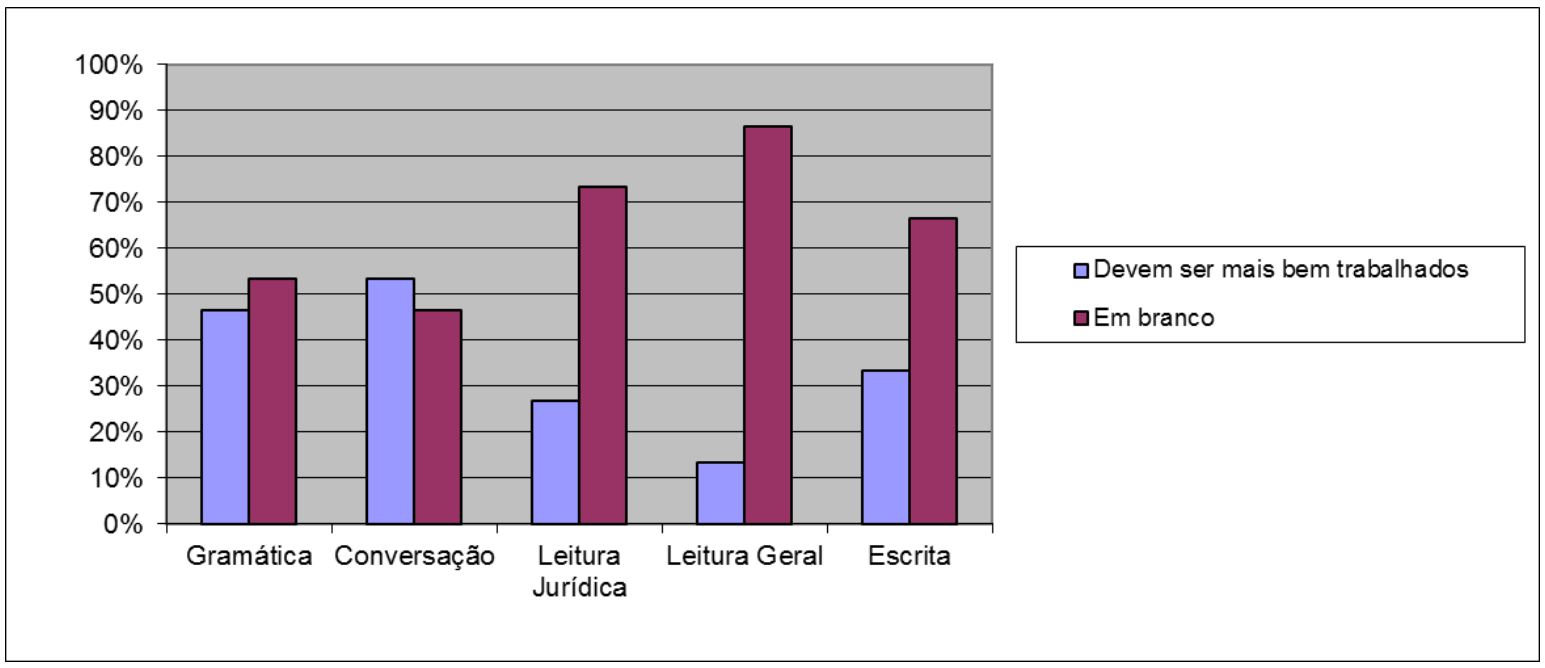

Gráfico 23- Aspectos a serem mais bem trabalhados durante o curso

\section{Q4-Qual a maior dificuldade no decorrer das aulas?}

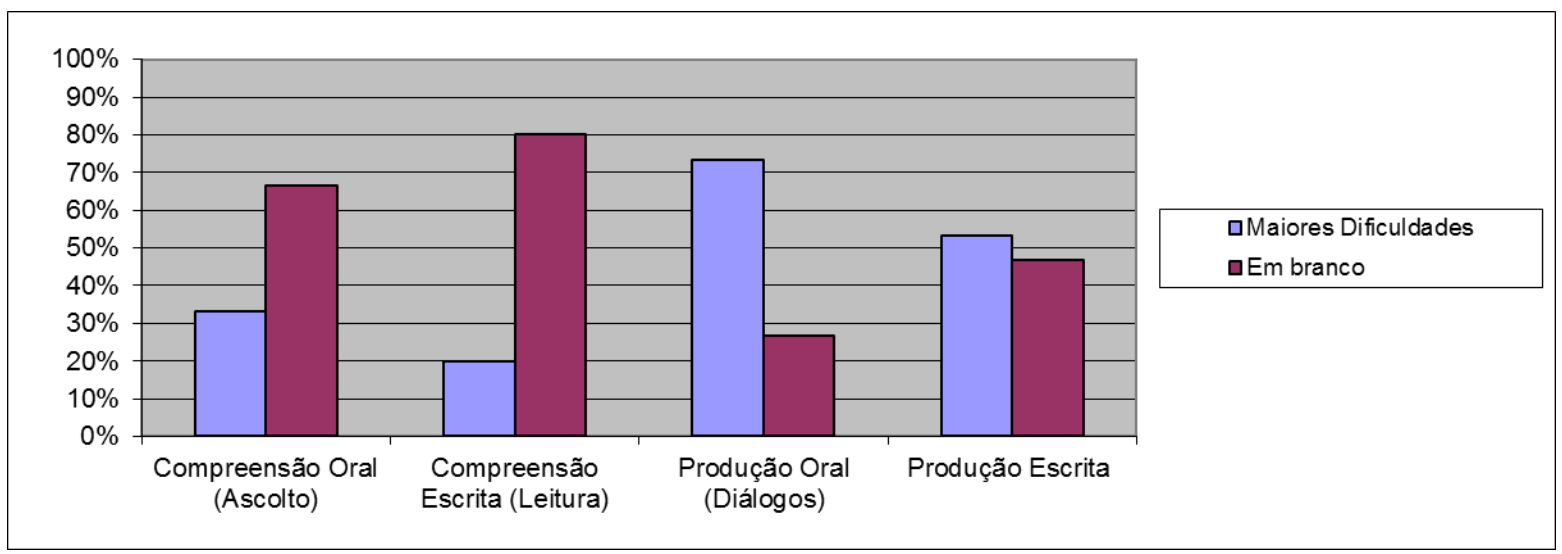

Gráfico 24- Maior dificuldade dos alunos durante as aulas 
Q5- Interesse em continuar o curso

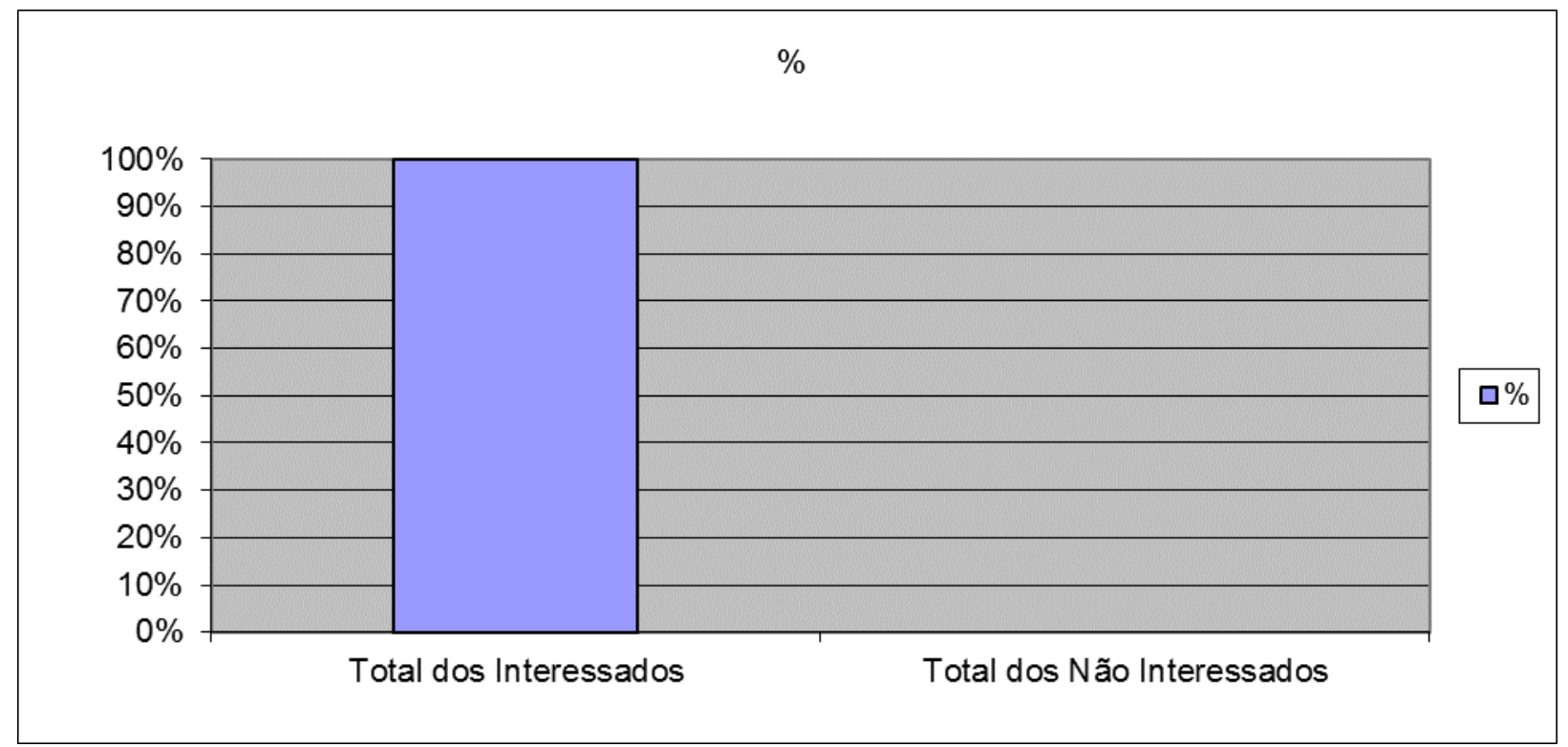

Gráfico 25- Interessados em continuar o curso

Q6- Tempo (in)suficiente para atingir as expectativas

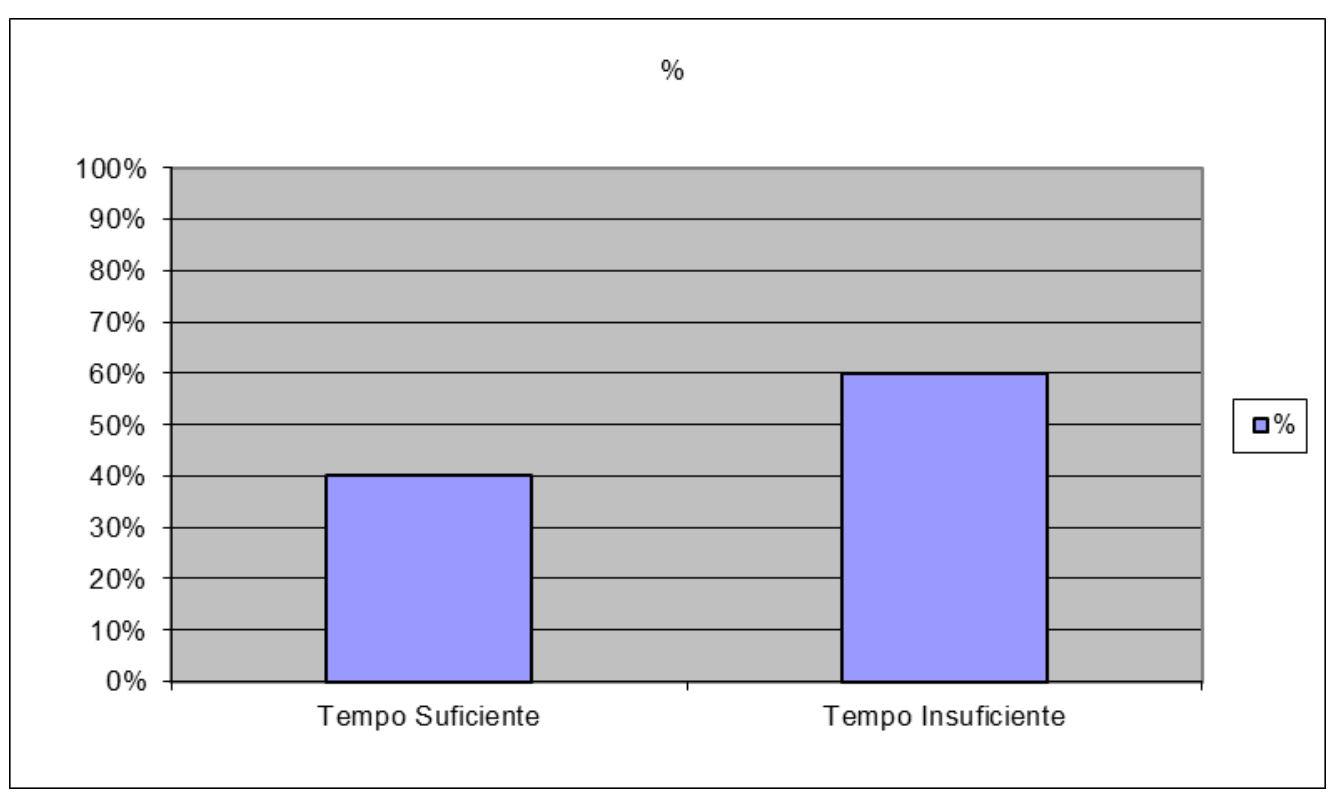

Gráfico 26- Relação entre o tempo e o alcance das expectativas 
Ao final das avaliações do segundo módulo, em novembro de 2013, notamos um progresso considerável no tocante ao desempenho dos alunos, e, atualmente, parece-nos que muitos deles:

- compreendem e utilizam adequadamente expressões do cotidiano;

- sabem apresentar-se e apresentar os outros e são capazes de formular perguntas e respostas sobre informações pessoais;

- interagem de modo simples, desde que a outra pessoa fale com clareza;

- compreendem frases e expressões usadas no âmbito jurídico;

- compreendem, com facilidade, textos jurídicos (não muito complexos);

- expressam, de modo simples, ideias e opiniões relacionadas ao Direito;

- são capazes de produzir textos simples relacionados ao interesse pessoal e jurídico.

Podemos dizer que, em nosso curso de italiano para juristas, foi possível trabalhar as quatro habilidades em nível elementar, que, no Quadro Comum Europeu corresponderia ao nível A. Gostaríamos de ter possibilitado que os aprendizes atingissem o nível B1, porém, por causa do tempo que tivemos à disposição (oito meses), isso não foi possível. Apesar disso, a nosso ver, comparados a discentes que estudam somente a língua italiana sem fins específicos, nossos alunos sobressaem-se, pois conseguem compreender facilmente textos de grau médio de dificuldade e, além disso, já aprenderam a 
utilizar estratégias de leitura, que podem ser aplicadas a qualquer gênero textual.

Claro está que nossos alunos, para atingirem um nível de proficiência na língua italiana (oral e escrita), deverão continuar a estudá-la; contudo, dentro da nossa proposta inicial, conseguimos atingir o nosso objetivo. 


\section{CONSIDERAÇÕES FINAIS}

Como dissemos no início desta dissertação, não encontramos nenhum trabalho que tratasse, especificamente, do ensino do italiano jurídico no Brasil. Por isso, esperamos que a presente dissertação possa representar uma contribuição a esse âmbito.

Neste trabalho, procuramos, em primeiro lugar, fazer uma análise de alguns livros didáticos empregados no ensino do italiano jurídico no Brasil. Chegamos à conclusão de que o manual Italiano per giuristi, da Alma Edizioni, pode ser usado com alunos iniciantes no estudo da língua italiana, pois apresenta uma linguagem simples e didatizada.

O livro Una lingua in Pretura, por sua vez, apresenta textos complexos, cuja compreensão exige dos estudantes conhecimentos linguísticos prévios. Por tal motivo, deve ser utilizado, a nosso ver, com estudantes que tenham o perfil indicado pelos autores desse manual didático, ou seja, aprendizes com o nível intermediário de conhecimento do idioma italiano.

Em segundo lugar, propusemos alguns cursos e analisamos, na prática, se as nossas propostas conseguiam atender as necessidades de aprendizagem dos discentes.

Em relação ao primeiro curso, realizado na $O A B$ de Jundiaí, concluímos que os resultados obtidos foram bastante satisfatórios, porque os alunos desenvolveram a compreensão de textos jurídicos mais complexos, tiveram avanços na produção escrita ao fazer resumos dos capítulos do livro Elogio dei Giudici e, ademais, desenvolveram a produção oral, que era o nosso principal objetivo. 
Vimos que, com os alunos que têm um nível intermediário de conhecimento do italiano, é possível trabalhar frequentemente textos autênticos e desenvolver tanto as habilidades escritas (compreensão escrita e produção escrita) quanto as orais (compreensão oral e produção oral).

No que concerne ao segundo curso, ministrado para os alunos de Direito da Faculdade São Francisco, o nosso objetivo consistia em trabalhar com aprendizes iniciantes no estudo do italiano. No decorrer desse curso, constatamos que, utilizando materiais didáticos e/ou materiais autênticos didatizados, é possível trabalhar tanto a língua geral quanto a específica contemporaneamente. Parece-nos, contudo, que, para desenvolver esse trabalho com alunos principiantes, o tempo mínimo de curso deveria ser de doze meses.

As respostas dos discentes da Faculdade de Direito do Largo São Francisco ao nosso questionário de avaliação do curso parecem indicar que eles se interessaram tanto pelas aulas que gostariam que houvesse outros módulos do curso. Parecem indicar, ademais, que os aprendizes gostariam que este passasse a ser uma disciplina optativa do currículo da graduação em Direito.

Pautando-nos na experiência que tivemos ao preparar e ministrar os cursos, podemos dizer que o formato ideal de curso para aprendizes que já tenham conhecimentos do idioma seja semelhante ao que realizamos com o grupo da $O A B$ - Jundiaí, desenvolvendo as quatro habilidades primárias e, também, as integradas. Já a nossa experiência com os estudantes da São Francisco mostrou-nos que é possível organizar e ministrar um curso de italiano jurídico também para alunos iniciantes no estudo do idioma. 
Todavia, o tempo de curso para atingir resultados plenamente satisfatórios, a nosso ver, deveria ser de, no mínimo, doze meses, ou o equivalente a cento e vinte horas-aula. Ademais, para que os discentes tivessem um melhor domínio da língua (tanto a geral quanto a com fins específicos), o tempo ideal de curso seria de duzentas e quarenta horas-aula.

Claro está que o professor precisa, ao iniciar as aulas, fazer a análise das necessidades de aprendizagem dos estudantes, como procuramos mostrar ao longo da presente dissertação.

Com base em todo esse trabalho que realizamos, acreditamos ser possível elaborar um manual didático específico para estudantes brasileiros de Direito que têm interesse em aprender o italiano jurídico; é o que pretendemos desenvolver futuramente, em nossa pesquisa de doutorado. 


\section{REFERÊNCIAS BIBLIOGRÁFICAS}

ALMEIDA FILHO, J.C.P. Linguística Aplicada, Ensino de línguas e comunicação. Campinas: Pontes, 2005.

Dimensões comunicativas no ensino de línguas- Campinas, SP- Pontes, $\overline{1998 .}$

ANPOLL. Grupo de trabalho de Lexicografia, Lexicologia e Terminologia da ANPOLL. Disponível em http://www.letras.ufmg.br/gtlexNovo/CMS/index.asp?pasta=gtlexnovo\&path=inic ial.asp\&pagina=inicial.asp. Acesso em novembro de 2013.

AMARAL, A. M. M. Dicionário Jurídico italiano-português. São Paulo: Ed. Federal,2006.

AVOLIO, J. C. Trajeto do francês instrumental no Brasil. In CELANI, M.A.A., FREIRE, M.M., RAMOS, R.C.G. A abordagem instrumental no Brasil: um projeto, seus percursos e seus desdobramentos. Campinas-SP: Mercado das Letras, 2009.

BALBONI, P. E. Didattica dell'italiano a stranieri, Bonacci, Roma, 1994. Tecniche didattiche per l'educazione linguistica: italiano, lingue straniere, lingue classiche. Torino, UTET Libreria, 2005. Imparare le lingue straniere. Venezia: Marsilio Editori, 2010.

Dizionario di glottodidattica. Collana: Biblioteca italiana di glottodidattica, Perugia, Guerra Edizioni, 1999.

Tecniche didattiche per l'educazione linguistica. Perugia, Guerra Edizione, 2007

BALDASSARRI, D. Lavorare in classe. Tecniche e attività nelle classi di italiano seconda lingua. Editore: Guerra Edizioni, 2008.

BALLARIN, E. Formazione degli insegnanti di lingua italiana nel mondo. Disponível em: http://venus.unive.it/filim, Didattica delle microlingue. Acesso em janeiro de 2011.

BARNI, M., TRONCARELLI, D., BAGNA, C. Lessico e apprendimenti: il ruolo del lessico nella linguistica educativa. Milão: FrancoAngeli, 2008.

BARTHES, R. Elementi di semiologia. Con un'appendice di testi inediti in italiano. Editore: Einaudi, 2002.

BECCARIA, G. L. Italiano: Antico e Nuovo. Perugia: Garzanti, 2002. et al. I linguaggi settoriali in Italia. Milano: Bompiani, 1988.

BECHARA, E. Moderna Gramática Portuguesa, $37^{a}$ ed. Rio de Janeiro: Nova Fronteira, 2009. 
BEGOTTI, P. Imparare da adulti, insegnare ad adulti le lingue. Perugia: Guerra, 2010.

BELLANOVA, B. La didattica dell'italiano nel quadro dell'educazione linguistica: finalità, metodologie e tecniche didattiche. Mirandola: CPE, 1992.

BELLUCCI, P. A onor del vero: fondamenti di linguistica giudiziaria. Rozzano (Mi): UTET, 2009.

BENUCCI, A. La grammatica nell'insegnamento dell'italiano. Roma: Bonacci, 1995.

BERRUTO, G.; SOBRERO, A.A.; et al. Introduzione all'italiano contemporaneo: la variazione e gli usi. Bari: Gius. Laterza \& Figli, 2006.

Sociolinguistica dell'italiano contemporaneo. Roma: La Nuova Italia Scientifica, 6를 ed. 1997

BONVINO, E. I materiali didattici per l'insegnamento dell'italiano L2: criteri di selezione. Ultima revisione: 04 settembre 2008. Disponível em: http://www.italicon.it/. Acesso em março de 2013.

BORELLO, E.; BALDI B. Settore che vai, linguaggio che trovi. Editore: II Libraccio, 2004

BORNETO, C. S. C'era una volta il metodo: tendenze attuali nelle didattiche delle lingue straniere. Roma: Carocci, 1998.

BRASIL. Constituição da República Federativa do Brasil de 1988. Disponível em http://www.planalto.gov.br/ccivil_03/constituicao/constituicao.htm. Acesso em janeiro de 2011.

Código Civil Brasileiro. Disponível em: http://www.planalto.gov.br/ccivil_03/leis/2002/l10406.htm. Acesso em janeiro de 2011.

BRUNI, F., ALFIERI, G., FORNASIERO, S., GOLDMANN, S. T. Manuale di scrittura e comunicazione. $2^{\mathrm{a}}$ ed. Bologna: Zanichelli, 2006.

RASO, T. Manuale dellitaliano professionale. Teoria e didattica. Bologna: Zanichelli, 2002.

CALAMANDREI, P. Eles, os Juízes, vistos por um advogado. São Paulo: Editora Martins Fontes, 2000. 2009.

Elogio dei giudici, scritto da un avvocato. Milano: Ponte alle Grazie,

CALVI, M.V. La traduzione nellinsegnamento della língua e nello studio dei linguaggi specialistici. Disponível em: http://www.academia.edu/460054/_La_Traduzione_NellInsegnamento_Della_Li ngua_E_Nello_Studio_Dei_Linguaggi_Specialistici. Acesso em janeiro 2012. 
CANDIDO, A., CARONI, I., LAUNAY, M. O Francês Instrumental: A experiência da Universidade de São Paulo. São Paulo: HEMUS-Livraria editora Ltda. 1977.

CARNELÓS, R. P. Estudo contrastivo da fraseologia presente em documentos jurídicos redigidos em português, francês e italiano: implicações na tradução juramentada e proposta de vocabulário fraseológico jurídico trilíngue.

Tese de Doutorado, disponível em: http://www.fflch.usp.br/dl/pos/teses/CARNELOSrosilea.pdf. Acesso em janeiro de 2011.

CELANI, M.A.A., FREIRE, M.M., RAMOS, R.C.G. A abordagem instrumental no Brasil: um projeto, seus percursos e seus desdobramentos. Campinas-SP: Mercado das Letras, 2009.

CILIBERTI, A. Glottodidattica: per una cultura dellinsegnamento linguistico. Roma: Ed. Carocci, 2012.

Manuale di glottodidattica. 5를. Ed. Milano: La nuova Italia, 2006.

CINTRA, M. M. A. Português instrumental: um percurso. In CELANI, A abordagem instrumental no Brasil: um projeto, seus percursos e seus desdobramentos. Campinas-SP: Mercado das Letras, 2009.

COLUCCIA, R. Le lingue della scienza oggi e ieri, in Le Parole della Scienza. Scritture tecniche e scientifiche in volgare (secoli XIII-XV). «Atti del Convegno (Lecce, 16-18 aprile 1999)», a cura di R. Gualdo, 7-18, 2001.

CORDA, A.; MARELLO, C. Lessico Insegnarlo e impararlo. 1ํㅡ. Ed. 1999, Torino, Paravia e $2^{\circ}$ Ed. Atualizada por Perugia, Guerra.

CORTELAZZO, M. Tre lezioni di lessicografia. 1989.

COVERI, L.; BENUCCI, A.; DIADORI, P. Le varietà dell'italiano: Manuale di sociolinguistica italiana. Siena: Bonacci, 1998.

DE MARCO, A. Manuale di glottodidattica. Scandicci-Florença: La Nuova Italia, 1994.

DE MAURO, T. Storia linguistica dell'Italia unita. 1986.

DEVOTO, G. II linguaggio d'Italia: storia e strutture linguistiche italiane dalla preistoria ai nostri giorni. Milano: Rizzoli, 1974.

I linguaggi settoriali in Italia, 1988.

DIADORI, P. Insegnare italiano a stranieri. Firenze: Le Monnier, 2001

DURAN, M. A. Lexicografia pedagógica e sua contribuição para a Mudança do paradigma lexicográfico. 2008. 
ELIA, A.; MARANO, F.; MONTELEONE, M.; SABATINO, S.; VELLUTINO, D. Universidade de Salerno, Itália. Departamento de Ciências da Comunicação. Disponível em: http://www.ledonline.it/ledonline/JADT-2010/allegati/JADT-20101227-1236_159-Elia.pdf. Acesso em janeiro 2012.

FALIERE, E. T.; ALLEN, P. O ensino instrumental de uma língua estrangeira. In MORDENTE, O., FERRONI, R. O ensino do italiano instrumental. São Paulo: Humanitas, 2011.

FIORELLI, P. La lingua del diritto e dell'amministrazione. in SERIANNI, L., TRIFONE, P. Storia della lingua italiana. $2^{\circ}$ v. Torino: Giulio Einaudi editore s.p.a., 1994.

FORAPANI, D., Italiano per giuristi. Firenze: Alma, 2003.

FREITAS, P. G. Proposta para o ensino de italiano por meio da culinária. Dissertação de Mestrado, disponível em: www.teses.usp.br/teses/.../8/8148/.../PAULA_GARCIA_DE_FREITAS.pdf. Acesso em janeiro de 2011.

GOTTI, M. UNIVERSITÀ DEGLI STUDI DI BERGAMO. Disponível em: http://dinamico.unibg.it/cerlis/page.aspx?p=4. Acesso em 10 de janeiro de 2013.

GUASTINI, R. I/ diritto come linguaggio. Lezioni. Editore: Giappichelli, 2006.

ITÁLIA. La Costituzione della Repubblica Italiana. Disponível em:

http://governo.it/Governo/Costituzione/principi.html. Acesso em janeiro 2011.

II codice civile italiano. Disponível em: http://www.ilcodicecivile.it/. Acesso em janeiro 2011.

KUMARAVADIVELU, B. Understanding language teaching: from Method to Postmethod. New Jersey: LEA, 2006.

LARANJEIRA, M.; LAUNAY, M. O francês instrumental na Universidade de São Paulo. In CANDIDO, A., CARONI, I., LAUNAY, M. O Francês Instrumental: A experiência da Universidade de São Paulo. São Paulo: HEMUS-Livraria editora Ltda. 1977.

MARAZZINI, C. Da Dante alla lingua selvaggia: Sette secoli di dibattito sullitaliano. Roma: Carocci, 1999.

MEZZADRI, M. Grammatica essenziale della lingua italiana con esercizi. Perugia: Ed. Guerra, 1999.

MICHELI, P., Test d'ingresso di italiano per stranieri, Roma: Bonacci Editore, 1995.

MIGLIORINI, B. Storia della lingua italiana. Milão: Bompiani, 1967. 
MONDAVIO, A. Abilità Relative Alla Lettura e alla Scritura. Ministero degli affari esteri. Disponível em http://www.italicon.it/it/modulo.asp?M=M00363. Acesso em janeiro de 2013.

MORDENTE, O., FERRONI, R. O ensino do italiano instrumental. São Paulo: Humanitas, 2011.

Habilidade de leitura em italiano no contexto universitário. São Paulo: Humanitas, 2011.

MORTARA, G. B. Le parole e la giustizia. Divagazioni grammaticali e retoriche su testi giuridici italiani. Editore: Einaudi, 2001.

OLIVEIRA, A. S. A codificação do Direito. Disponível em http://jus.com.br/artigos/3549/a-codificacao-do-direito\#ixzz2c4NYMEQ7. Acesso em 15 de agosto de 2012.

ONDELLI, S., La lingua del diritto: proposta di classificazione di una varietà dell'italiano. Aracne Editore, 2007.

PAIVA, V.L.M.O. O lugar da leitura na aula de língua estrangeira Vertentes. n. 16 - julho/dezembro 2000. p.24-29.

PALMIERI, G. Dizionario dei termini giuridici. Milano: BUR Dizionari, 2006.

PERLINGIERI, P. II Diritto Civile nella legalità costituzionale secondo il sistema Italo-Comunitario delle fonti. Edizioni Scientifiche Italiane, 2006.

PICHIASSI, M., Apprendere l'italiano L2 nell'era digitale. Le nuove tecnologie nell'insegnamento e apprendimento dell'italiano per stranieri. Editore: Guerra Edizioni, 2007.

PORCELLI, G.; DOLCI R. Multimedialità e insegnamenti linguistici. Ed.: UTET Università, 2006.

RAJAGOPALAN, K. Por uma linguística crítica: linguagem, identidade e a questão ética. São Paulo: Parábola, 2003.

RAMOS, R. C. G. A história da abordagem instrumental na PUCSP. In CELANI, A abordagem instrumental no Brasil: um projeto, seus percursos e seus desdobramentos. Campinas-SP: Mercado das Letras, 2009.

REINER A., Glottodidattica settoriale modularizzata per gruppi scientifici: l'italiano per giuristi ed economisti. Ed.: Accademia Europea di Bolzano,1997.

ROVERE, G., Capitoli di linguistica giuridica. Ricerche su corpora elettronici. Editore: Edizioni dell'Orso, 2005.

SABATINI, F. La comunicazione e gli usi della lingua. Torino: Loescher Editore, 1998. 
SACCO, R.; GAMBARO, A. Sistemi giuridici comparati. Torino: UTET, 1998.

SAUSSURE, F. Corso di linguistica generale. Editore: Laterza, 2009.

SEDYCIAS, J. Universidade Federal de Pernambuco. Disponível em: http://descomplicandoingles.blogspot.com/2009/02/o-que-e-ingles-

instrumental.html. Acesso em abril 2012.

SEMPLICI, S., Una Lingua in Pretura, il linguaggio del diritto. Università per Stranieri di Siena: Bonacci editore, 1996.

SERIANNI, L., TRIFONE, P. Storia della lingua italiana. $2^{\circ}$ v. Torino: Giulio Einaudi editore s.p.a., 1994.

SEVERINO, A. J., Metodologia do trabalho científico. São Paulo: Cortez, 2002.

SOBRERO, A.A., MIGLIETTA, A. Introduzione alla linguistica italiana. RomaBari: Gius. Laterza \& Figli Spa, 2006.

TRECCANI. Enciclopedia Italiana. Disponível em: http://www.treccani.it/. Acesso em janeiro 2011.

VIEIRA, D. A. O uso de materiais autênticos nas aulas de italiano como língua estrangeira: teorias e práticas. São Paulo: Ed. Nova Alexandria, 2012.

WELKER, H. A. O uso de dicionários: Panorama geral das pesquisas empíricas. Brasília: Thesaurus, 2006 Lexicografia Pedagógica Pesquisas e Perspectivas. UFSC/NUT, 2008.

WIDDOWSON, H. G. O ensino de línguas para a Comunicação. Campinas: Pontes, 1991.

ZIGLIO, L., RIZZO, G. Espresso 1- Corso di italiano. Firenze: Alma, 2011.

ZOLLI, P. Saggi sulla lingua italiana dell'Ottocento. Pisa: Pacini, 1974.

ZUCCHI, A. M. T., O dicionário no estudo de línguas estrangeiras: os efeitos de seu uso na compreensão escrita em italiano. Tese de Doutorado. Universidade de São Paulo. São Paulo, 2010. 


\section{APÊNDICES}

\section{APÊNDICE A- Questionário respondido pelos alunos ao final do curso da Oab- Jundiaí}

\section{AVALIAÇÃO DO CURSO ITALIANO PER GIURISTI- OAB JUNDIAÍ}

1) As suas expectativas iniciais a respeito do curso de Italiano para Juristas foram alcançadas?

2) Qual a sua opinião sobre o livro "Italiano per giuristi"?

3) Quais suas impressões a respeito do livro "Italiano in Pretura"?

4) Qual a atividade mais interessante que foi desenvolvida no curso?

5) Qual a atividade que você considera menos interessante do curso?

6) Você acredita que foi importante trabalhar com a compreensão dos textos do livro "Elogio dei giudici" de Piero Calamandrei? Justifique sua resposta.

7) Como você avalia o seu desempenho no curso e o que você acredita que tenha contribuído na sua formação profissional e pessoal?

8) Quais os pontos positivos e os pontos negativos do curso?

9) O que contribuiu mais para o desenvolvimento e aproveitamento do curso? A didática da professora, os livros adotados ou a sua própria dedicação pessoal?

10) Deixe suas críticas ou sugestões:

Nome: Data: 


\title{
APÊNDICE B- Prova de compreensão de textos realizada com os alunos da OAB- Jundiaí
}

\author{
VALUTAZIONE \\ Corso di italiano per giuristi \\ OAB- Jundiaí
}

Alunno:

Data:

\section{Leggere e rispondere alle domande:}

\section{Il Brasile apre le reti di trasporto ai capitali privati}

Autostrade, ferrovie, porti e aeroporti. Il Brasile di Dilma Rousseff rallenta la sua corsa, ma il programma di infrastrutture già avviato dall'ex presidente Lula, prosegue a ritmi serrati.

Opere monumentali per un Paese che ha un mercato interno di oltre 190 milioni di persone e un'estensione pari a 27 volte l'Italia.

L'Ambasciata italiana in Brasile ha organizzato, per il prossimo 13 marzo, il seminario "La collaborazione italo-brasiliana per lo sviluppo delle infrastrutture". All'incontro parteciperà il ministro dell'Ambiente Corrado Clini e il presidente dell'Agenzia Ice, Riccardo Monti, oltre al management di grandi gruppi italiani.

La prima necessità, a fronte delle grandi opere programmate, è il

finanziamento: le stime delle autorità brasiliane si avvicinano ai 250 miliardi di reais (circa 100 miliardi di euro) da spalmare nei prossimi trent'anni.

L'intervento del settore pubblico brasiliano avverrà attraverso finanziamanenti a tassi agevolati del Banco nacional do desenvolvimento economico e social (Bndes), il poderoso canale finanziario brasiliano.

Si tratta di uno schema di finanziamento a partecipazione pubblico che poggia sul metodo della concessione ai privati dello sfruttamento dei proventi. Il programma di adeguamento infrastrutturale varato dal Governo è articolato in grandi comparti.

\section{Porti}

È quello portuale uno dei settori a maggiore sviluppo; oggi, nella classifica mondiale dell'efficienza del comparto, il Brasile si situa al $130^{\circ}$ posto, in una classifica di 144 posizioni. Quindi tra gli ultimi del mondo. Una spiegazione chiara arriva da Ed Sands, manager di Procurian, società di logistica con sede in Pennsylvania. «Un vero decollo economico, per un Paese come il Brasile, non può prescindere dallo sviluppo dei porti. Anche perché India e Cina hanno investito miliardi di dollari in questo settore».

L'impegno finanziario è di oltre 20 miliardi di euro nei prossimi 5 anni. La prossima settimana il ministro delle Finanze Guido Mantega farà un road show 
a New York.

Oltre agli investimenti previsti dal Pac (Programma per la crescita accelerata), il Governo federale intende realizzare opere per la modernizzazione di sette porti che riceveranno navi passeggeri durante la Coppa del Mondo 2014 e le Olimpiadi 2016. I porti cui è destinato un ingente flusso di fondi sono i seguenti: Salvador, Recife, Natal, Fortaleza, Santos, Rio de Janeiro e Manaus. Le procedure per l'assegnazione dei lavori di rinnovamento dei porti dovrebbero invece concludersi entro la metà del 2014. Anche se gli scioperi per le privatizzazioni, già cominciati, potrebbero rallentare la modernizzazione.

\section{Aeroporti}

Saranno 270 gli aeroporti interessati alla ristrutturazione. In vista della Coppa del Mondo di calcio verrà completata la concessione ai privati della gestione dei principali aeroporti internazionali. Dopo quello di San Paolo e di Brasilia, il Governo ha annunciato la privatizzazione degli aeroporti di Rio e di Belo Horizonte. Una valutazione di mercato arriva da Luiz Henrique Kleine, analista di "Magliano Correttora de cambio \& valores mobiliares": «A parità di condizioni tecnologiche e dimensionali, le società industriali che i mercati finanziari brasiliani, guardano con maggiore favore sono quelle già operative sul suolo brasiliano che hanno dimostrato efficienza».

\section{Rete ferroviaria}

Il piano ferroviario riguarda 10mila chilometri di linee per un ammontare complessivo di 35 miliardi di euro. Un'altra priorità espressa dal Governo brasiliano è l'espansione e l'ammodernamento della rete ferroviaria. Con l'obiettivo di uscire dall'attuale regime di monopolio. Di recente è stata annunciata la pubblicazione di 12 lotti, quasi tutti per la costruzione di nuove linee. Le gare per i lavori da effettuare sulla rete ferroviaria e stradale e per l'assegnazione a privati della gestione degli aeroporti internazionali di Belo Horizonte e di Rio de Janeiro dovrebbero essere concluse entro l'autunno.

\section{DOMANDE:}

1) Quale è la prima necessità discussa durante l'incontro organizzato dall'Ambasciata italiana in Brasile, il 13 marzo?

2) Quali dovrebbero essere i provvedimenti adeguati riguardo ai porti Brasiliani?

3) Cosa succederà in vista della Coppa del Mondo con gli aeroporti?

4) Quale sarebbe la priorità del Governo brasiliano riguardo alla rete ferroviaria? 


\section{APÊNDICE C- Atividade de compreensão escrita realizada com os alunos da OAB- Jundiaí a partir de um capítulo do livro Le perfezioni provvisorie de Gianrico Carofiglio, p. 100 a 109.}

\section{LE PERFEZIONI PROVVISORIE \\ Cap. 12 , p. 100}

II mio cliente era un ragazzo di venticinque anni ed era imputato di strage.

Detta così la cosa fa un certo effetto ed evoca immagini tragiche, odore acre di polvere da sparo, morti ammazzati, urla, feriti, sangue e sirene di ambulanze.

Leggendo il capo di imputazione e gli atti del processo le cose apparivano alquanto diverse. L'atto d'accusa specificava infatti che Nicola Costantino era imputato del reato previsto e punito dall'articolo 422 comma secondo del codice penale perché, al fine di uccidere se stesso, compiva atti in grado di porre in pericolo la pubblica incolumità, in particolare aprendo le bocchette del gas nella sua abitazione con l'intenzione, quando l'aria fosse stata satura, di produrre un'esplosione, potenzialmente idonea a distruggere l'intero stabile; evento distruttivo non verificatosi solo per l'intervento dei carabinieri.

Nicola Costantino, da tempo in cura per problemi psichiatrici, aveva cercato di suicidarsi con il gas. Era solo in casa, si era chiuso in cucina, aveva bevuto mezza bottiglia di rum e assunto una dose robusta di ansiolitico e poi aveva aperto tutti i fornelli. Una vicina dall'olfatto sensibile si era accorta quasi subito che qualcosa non andava e aveva chiamato i carabinieri. I militari - "prontamente sopraggiunti", come si leggeva nell'informativa -, dopo aver sfondato porte e spalancato finestre, avevano trovato il ragazzo a terra, privo di sensi ma miracolosamente non ancora dall'altra parte. In sostanza gli avevano salvato la vita. Ma dopo essersi consultati con il magistrato di turno, l'avevano anche arrestato. Per strage.

Consultando un manuale di diritto penale si può scoprire che per la sussistenza del reato di strage non è necessário che muoia qualcuno: basta che se ne verifichi il pericolo, purché la condotta sia realizzata con l'obiettivo specifico di uccidere.

Il caso di scuola è quello del terrorista che coloca in luogo pubblico una bomba ad alto potenziale, pronta a esplodere. L'ordigno non esplode, magari per l'intervento della polizia, magari per un difetto di funzionamento, ma il terrorista risponde comunque di strage perché la sua intenzione era di uccidere un numero indistinto di persone e la sua condotta era idonea a produrre quel risultato.

La storia del mio cliente era, come dire, leggermente diversa. Nicola Costantino non era un terrorista ma solo um ragazzo mingherlino, disturbato e irrimediabilmente incline al falimento. Aveva deciso di togliersi la vita e non c'era riuscito, mostrando che la sua attitudine a non riuscire in nulla si estendeva anche al campo delle attività autolesionistiche.

Non vi è dubbio che facendo la sciocchezza di aprire il gas aveva messo in pericolo l'incolumità di tutti gli abitanti del palazzo; non vi è dubbio allo stesso modo che quell'azione idiota non era ispirata dall'intenzione di uccidere nessuno, a parte se stesso.

Era questo l'elementare argomento che avevo cercato di esporre al pubblico ministero e al tribunale della libertà, per sostenere che il delito di strage non poteva configurarsi e che non c'era dunque una base giuridica per trattenere in carcere il mio cliente.

Non ero stato persuasivo. I giudici del tribunale della libertà scrissero, nel motivarei il rigetto della mia istanza, "che è suficiente, perché si realizzi il delito di 
strage, che qualcuno abbia l'intenzione di uccidere chicchessia, dunque anche solo se stesso".

L'argomento era munito di una forza paradossale e quasi ipnotica.

Non aveva forse il Costantino messo in pericolo la pubblica incolumità con il suo tentativo - fallito solo grazie al tempestivo intervento delle forze dell'ordine - di uccidere se stesso? Egli era dunque pacificamente responsabile del delito di strage, di cui sussistevano tutti i requisiti, oggettivi e soggettivi.

$\mathrm{E}$ siccome le modalità del fatto e la personalità instabile dell'indagato (l'único punto su cui mi sentivo di concordare con i giudici) lasciavano ragionevolmente ipotizzare il rischio di reiterazione di condotte della stessa specie, appariva inevitabile la conferma della misura cautelare, nella sua forma più penetrante della custodia in carcere.

Mi accingevo a fare ricorso per cassazione contro questa bislacca interpretazione della legge penale, quando i genitori vennero a trovarmi. Parevano in leggero imbarazzo, ma dopo qualche esitazione riuscirono a dirmi, in modo molto direto, che non volevano che facessi il ricorso.

"Perché?" chiesi io, esterrefatto.

I due si guardarono negli occhi, come per decidere chi dovesse rispondere.

"Se è un problema di parcella - dissi ricordandomi di quanto avevo chiesto per il ricorso - non preoccupatevi, mi pagherete quando sarà possibile".

Mi rispose il padre.

"No, grazie avvocato, non è una questione di soldi. II fatto è che Nicola, da quando è in carcere, sta meglio. Lo trattano bene, sia gli agenti che gli altri detenuti. Socializza, ha fatto amicizie, e quando andiamo a trovarlo sembra quasi allegro. Per dirla tutta, non lo vediamo così bene da anni".

lo li guardai con l'espressione di uno che non ha sentito bene. II padre si strinse nelle spalle.

"Lasciamolo lì dentro ancora qualche mese" aggiunse la madre, con una espressione in cui si mescolavano senso di colpa, sollievo e addirittura una leggera allegria.

"Quando si arriva al processo siamo sicuri che lei lo farà assolvere, uscirà dal carcere e potremo aiutarlo a ricostruirsi una vita. Nel frattempo però lasciamolo ancora um po' lì, visto che gli fa bene. È como se fosse una casa di cura" concluse il padre, con l'espressione sollevata di chi ha portato a termine un compito difficile.

lo stavo per dire che Nicola era maggiorenne e dunque per ragioni di etica professionale dovevo chiedere la sua opinione su questa originale soluzione.

Invece ci pensai qualche secondo, presi una decisione di cui non avrei voluto fosse informato il consiglio dell'ordine degli avvocati, e non dissi niente. Mi limitai ad allargare le mani, palmi in alto, in gesto di resa.

Mesi dopo giunse il momento dell'udienza preliminare.

Quella mattina, prima del mio, c'era un altro processo con molte decine di imputati per una storia di truffe alla previdenza sociale. L' aula - la più grande, fra quelle destinate alle udienze preliminari - era piena di imputati e dei loro avvocati, e aveva l'ordinata compostezza del suk di Marrakesh. Tutto lasciava presagire che la faccenda sarebbe andata per le lunghe. Così, non sapendo come far passare il tempo, presi l'iPod che avevo in borsa e lo feci partire in riproduzione casuale.

La scena, all'improvviso e come per magia, si tramutò in uno spettacolo di insensata, mitica, demente bellezza.

Seguendo, senza saperlo, il ritmo del rock, avvocati, imputati, giudice, cancelliere, agenti di custodia danzavano sincopati sul mio palcoscenico personale.

Avvocati che si alzavano e parlavano dicendo cose che non sentivo, imputati che confabulavano fra loro, il giudice che dettava a verbale: una sorta di movimento coletivo che, grazie alla musica, sembrava acquistare senso e necessità. 
II momento più esaltante di quel musical privato fu quando un mio collega, la cui più caratteristica specialità professionale era, ed è, il disprezzo implacabile per il congiuntivo, si alzò e si rivolse al giudice gesticolando animatamente, in perfetta almeno mi parve - sincronia con la voce di Freddie Mercury che cantava Don't stop me now.

A volte non è male fare l'avvocato, pensai, mentre allungavo i piedi sotto il banco e mi godevo lo spettacolo.

Terminata l'udienza preliminare per le truffe INPS, sgomberata l'aula, riposti gli auricolari, arrivò il nostro turno. Eravamo rimasti solo il giudice, il cancelliere, io, Consuelo - che nel frattempo era arrivata dopo aver fato un giro di cancellerie -, il pubblico ministero, il mio cliente e i due agenti di custodia che lo avevano accompagnato e lo sorvegliavano atentamente. Ove mai gli fosse venuto in mente di aprire il gas e fare una strage anche lì in tribunale.

Dopo aver sbrigato le formalità di apertura il giudice chiese se ci fosse qualche richiesta. lo mi alzai e dissi che il signor Costantivo desiderava essere sottoposto all'interrogatorio. La richiesta era giustificata dal fatto che l'imputato era stato sentito solo una volta, al momento della convalida, due giorni dopo l'arresto, quando, per usare un eufemismo, era ancora non perfettamente lucido.

Il giudice dettò un breve provvedimento a verbale, diede ordine agli agenti di custodia di accompagnare l'imputato davanti a lui e poi invitò il pubblico ministero a cominciare.

"Lei ha letto il capo d'imputazione?" chiese il pubblico ministero. Nicola lo guardò smarrito, dovendogli sembrare che la domanda fosse troppo idiota. Poi colse un mio cenno del capo e comprese che doveva davvero rispondere.

"Certo, sì".

"Lei ha fatto quelle cose che ci sono scritte?".

"Ho aperto il gas perché volevo farla finita. Ma mica volevo fare uma strage. Anche se poi mi sono reso conto, quando non ero più fuori di testa, che avrei potuto fare un vero casino".

"Vuol dire che si è reso conto di aver posto in essere condotta idonea a mettere a repentaglio l'incolumità pubblica?".

Stavo per fare opposizione, ma ci ripensai. L'opposizione era del tutto inutile, visto che era del tutto inutile la domanda. II mio cliente, che come ho detto non era eccessivamente acuto, rispose però in modo adeguato e dopo altre due o tre domande il pubblico ministero aveva finito.

"Vuol procedere lei, avvocato Guerrieri?" disse il giudice.

"Grazie giudice, pochissime domande, perché, come lei sa bene, la chiave del processo è in diritto più che in fatto". Feci una pausa e mi parve di cogliere un impercettibile segno di assenso da parte del giudice. Questo non sempre è un bene, ma quel giorno il giudice era uno preparato e anche intelligente, e dunque il moto del capo mi parve di buon auspicio.

"Signor Costantino, è un dato pacifico che lei abbia aperto il gas e che fosse intenzionato a commettere suicidio. Non torneremo su questo punto. Voglio chiederle invece: nel momento in cui ha aperto il gas, lei era intenzionato a uccidere qualcun altro?".

"No, è chiaro".

"Nel momento in cui ha aperto il gas, ha ipotizzato, si è immaginato che da quel gesto potesse derivare la morte di altre persone, oltre alla sua?".

"No, no, volevo solo addormentarmi e farla finita. Ho detto che ero fuori testa, prendevo le medicine...".

"Vuol dire che prendeva degli psicofarmaci?".

"Sì, le medicine per la depressione".

"Lei ha detto che solo dopo si è reso conto delle conseguenze che sarebbero potute derivare dal suo comportamento. Ho capito bene?". 
"Sì, parecchi giorni dopo, quando cominciavo a stare meglio. In carcere".

"Grazie. Io non ho altre domande".

"Va bene. Se non ci sono altre richieste direi che le parti possono concludere" disse il giudice.

II pubblico ministero si alzò e ripropose la sua innovativa interpretazione della fattispecie di strage. II reato richiede l'intenzione di uccidere, senza alcuna specificazione del destinatario di tale intenzione. II Costantino, al momento della sua condotta, aveva avuto l'intenzione di uccidere se stesso e comunque aveva accettato implicitamente il rischio di uccidere altre persone. Tanto bastava perché fosse rinviato a giudizio e sucessivamente condannato. Per strage.

Poi toccò a me.

"Mi permetterà, signor giudice, di non limitarmi alle pocchissime parole che di solito si riservano in udienza preliminare alla rituale, e spesso inutile, richiesta di proscioglimento. Perché questo è uno dei casi in cui il proscioglimento è davvero possibile sin da questo momento, senza attendere i tempi di un processo in corte d'assise. E a dire la verità la sola idea di andare dinanzi alla corte d'assise per una fuga di gas, ancorché volontariamente provocata, presenta aspetti paradossali se non addirittura grotteschi".

II giudice aveva preso carta e penna e scriveva. Registrai mentalmente la circostanza, pensai che poteva essere um buon segno, anche se i giudici sono creature imprevedibili, e proseguii.

"Non vi è dubbio che questo processo deve essere risolto sul piano del diritto, della interpretazione della legge penale, posto che i fatti sono pacifici nella loro banale semplicità: un ragazzo infelice e depresso cerca di suicidarsi, i carabinieri intervengono, salvano il ragazzo e sventano una possibile tragedia. La domanda cui il processo deve dare risposta è dunque la seguente: il comportamento di questo ragazzo integra tutti gli estremi del delitto di strage? Delitto, è bene ricordarlo, punito con la reclusione non inferiore a quindici anni".

Parlai una decina di minuti, cercando di comunicare un concetto elementare: sussiste il delitto di strage - anche se non muore nessuno - solo quando l'imputato ha agito con l'intenzione di uccidere un numero indeterminato di persone, perché si tratta di un delitto contro l'incolumità pubblica. Molto banalmente: se uno vuole uccidere se stesso, non vuole fare una strage. $\mathrm{E}$ così se non muore nessuno, semplicemente non c'è reato.

Mi accorsi che facevo fatica a spiegare una cosa talmente ovvia. Forse troppo ovvia per essere argomentata con efficacia. Quando finii di parlare ero insoddisfatto di me e convinto che il giudice avrebbe rinviato a giudizio il mio cliente.

Quello invece scrisse rapidamente qualcosa, si alzò in piedi e lesse: non bisognava procedere a carico di Costantino Nicola perché il fatto a lui contestato non costituiva reato. L'imputato andava imediatamente rimesso in libertà se non detenuto per altra causa.

L'udienza finì così, bruscamente, e il giudice era già scomparso in camera di consiglio quando io mi avvicinai al ragazzo per dirgli che era stato prosciolto e che nel giro di qualche ora - il tempo delle formalità in carcere - sarebbe tornato in libertà.

"Complimenti, io ero sicura che l'avrebbe rinviato a giudizio, per non prendersi la responsabilità di decidere e la seccatura di scrivere la sentenza" disse Consuelo mentre uscivamo dall'aula.

"Anch'io non ci speravo molto, nel proscioglimento".

"E adesso?".

"Adesso cosa?".

"I genitori saranno più contenti del fatto che Nicola è stato prosciolto o più preoccupati di quello che potrebbe succedere ora che torna a casa?".

Era quello che, in quel momento, mi stavo chiedendo anch'io. $E$ naturalmente una risposta non ce l'avevo. 


\section{APÊNDICE D- Questionário respondido pelos alunos no início do primeiro módulo do curso da São Francisco- USP}

\section{CURSO DE ITALIANO PARA JURISTAS \\ QUESTIONÁRIO}

NOME:

E-mail:

1) IDADE:
( ) de 18 a 20 anos
( ) de 21 a 25 anos
( ) de 26 a 30 anos
( ) de 31 a 35 anos
( ) de 36 a 40 anos
( ) de 41 a 45 anos
( ) de 46 a 50 anos
( ) de 50 a 55 anos
( ) de 56 a 60 anos
( ) de 61 a 65 anos
( ) de 66 a 70 anos
( )acima de 70 anos

2) SEXO:
( ) masculino
( ) feminino

3) ESTADO CIVIL:
( ) solteiro
( ) casado
( ) viúvo
( ) convivente
( ) divorciado
( ) outro

4) TEM FILHOS?
( ) $\operatorname{sim}$
( ) não

5) É GRADUANDO? CURSA QUAL PERÍODO?

6) É PÓS-GRADUANDO? QUAL A ESPECIALIDADE?

7) COMO FICOU SABENDO DO CURSO?

8) JÁ ESTUDOU ANTERIORMENTE A LÍNGUA ITALIANA?
( ) $\operatorname{sim}$
( ) não

9) QUAL O NÍVEL, QUE VOCÊ ACREDITA TER ALCANÇADO, DO IDIOMA?
( ) nenhum
( ) básico
( ) intermediário
( ) avançado

10) QUAIS AS SUAS EXPECTATIVAS EM RELAÇÃO AO CURSO DE ITALIANO PARA JURISTAS?

11) O QUE VOCÊ GOSTARIA DE ESTUDAR COM MAIS PROFUNDIDADE?
( ) gramática ( ) conversação
( ) leitura
( ) outro. Especificar 


\section{APÊNDICE E- Teste aplicado para avaliar o nível dos alunos do primeiro módulo do Curso da Faculdade de Direito- USP}

\section{Test di ingresso e progresso Espresso}

Questo test, con cui potrete verificare il livello di conoscenza dei vostri studenti, vi permetterà di inserirli nel corso a loro più congeniale.

\section{Svolgimento}

Il test consiste di 46 brevi esercizi con risposta univoca, che trattano i temi affrontati in Espresso 1, Espresso 2 e Espresso 3. Il punteggio ottenuto permette di suddividere gli allievi in 6 diversi livelli.

Per ogni risposta corretta si ottiene un punto. Un livello si considera superato se si ottiene almeno il $75 \%$ del punteggio totale (vedi sotto Punteggio).

Il tempo a disposizione dello studente dovrebbe essere al massimo di 5-7 minuti.

\section{Punteggio}

Domande 1-8: 14 punti o più ... Espresso 1, Lezione 6 (con meno di 14 punti tornare alla

\section{Lezione 1)}

Domande 9-16: 20 punti o più ... $\quad$ Espresso 2, Lezione 1

Domande 17-24: 12 punti o più ... $\quad$ Espresso 2, Lezione 6

Domande 25-32: $\quad 13$ punti o più ... $\quad$ Espresso 3, Lezione 1

Domande 33-40: 13 punti o più ... Espresso 3, Lezione 6

Domande 41-46: $\quad 34$ punti o più ... Livello avanzato 


\section{Test di ingresso e progresso \\ Espresso}

Nome:

Iniziate con il primo esercizio e rispondete alle domande solo finché vi sentite sicuri.

Le domande saranno sempre più complicate. Appena iniziate a scegliere a caso le risposte, smettete.

\section{Completa.}

1 Arianna in un ufficio.
a. lavora
b. lavoro
c. lavori

3 Voi di Milano?
a. siete
b. siamo
c. sono

2 Lei
a. faccio
b. fai
c. fa

4 Tu quanti anni $?$
a. hai
b. ho
c. abbiamo

5 Vorrei (1) aperitivo, (2) toast e poi (3) aranciata.
(1)
a. uno
b. un'
c. un
(2) a. uno
(3) a. una
b. un'
b. un'
c. un
c. un

6 Preferisci (1) tortellini o

(2) lasagne?

(3) spaghetti o

(4) tagliatelle?
(1) a. gli
(2) a. gli
(3) a. Gli
b. I
(4) a. gli
b. i
c. Le
b. $\mathrm{i}$
c. le
c. le
c. le

$7 \quad v$ Voi cosa (1) nel tempo libero?

$\tau$ Di solito

$v$ Io invece (2) sport:
(1) a. fare
a. fare
b. fate
(2)
a. facciamo
b. fanno
c. fanno
c. fate (4) quasi sempre a casa.

(3)

a. andate
b. andiamo
c. vanno

(4) a. fai

b. sta

c. sto

8 (1) febbraio affitto appartamento situato (2) zona centrale, (3) ogni comfort e vicino (4) mare.
(1) a. Nel
(2) a. in
b. In
b. di
(3) a. su
(4) a. di
c. Di
c. nel
b. con
c. di
b. da
c. al

Punti: 


\section{Completa.}

9 La signora Vanzetta conosce bene Bologna e (1) va spesso, perché ha clienti

lì. In questa città (3) tante cose da vedere: delle (4) chiese, (5) musei interessanti e spesso delle mostre.
(1) a. ci
(2) a. i
b. Bologna
b. pochi
(3) a. c'è
b. ci sono
(4) a. bello
(5) a. dei
c. in città
c. dei
c. può vedere
b. belle
b. $\mathrm{i}$
c. degli

$10 \vee C^{\prime}$ è una libreria qui vicino?

$\tau$ Sì, dunque Lei adesso

(1) dall'albergo, poi gira subito

(2) e lì,

(3) il supermercato e la banca, c'è la libreria Artigianelli.
(1) a. gira
(2) a. a destra
b. avanti
(3) a. davanti
b. va
c. dritto
b. fra
c. esce
c. all'angolo

c. ditto

11 v Scusi, sa (1) l'hotel Lux?

$\tau$ No, (2), non sono di qui.
(1) a. se c'è
b. dov'è
(2) a. allora
b. si figuri
c. c'è
c. mi dispiace

12 Carlo e Anna

(1) due belle giornate. Ieri

(2) in un museo e poi

(3) in un ristorante tipico. Oggi

(4) una mostra insieme e la sera

Anna (5) anche al cinema.
(1) a. sono passati
(2) a. sono stati
b. è stato
b. hanno passato
c. sono state
c. ha passato
(5) a. sono andati
a. hanno visitato
b. è andata
c. abbiamo visitato
c. è andato

(3) a. ho pranzato

b. avete pranzato

13 La signora Cusimano va in un negozio di alimentari e prende due etti di mortadella, ma (1) vuole affettata molto sottile. Desidera anche del formaggio,

(2) vuole

stagionato e (3) prende tre etti. Poi compra anche delle olive:

(4) vuole nere e grosse.
(1) a. la
(2) a. ne
b. lo
b. 10
(3) a. ne
b. 10
(4) a. ne
c. ne
c. la
c. li
b. la
c. le

\section{Qual è la risposta corretta?}

14 Ti alzi presto la mattina?
a. Sì, verso le sei.
b. Sì, dopo pranzo.
c. Dalle otto alle dieci.

15 Che taglia porta?
a. La 52.
b. Un capo classico.
c. Un paio di pantaloni. 


\section{Completa.}

16 Il signor Ferri va con la moglie in un negozio di scarpe. Vede dei mocassini che piacciono molto, ma sono troppo cari. La moglie vede delle scarpe (2) care che (1) _ (3) sembrano pure comode. Il marito (6) compra.
(1) a. li
(2) a. più
b. meno
(3) a. gli
b. le
(4) a. lo
b. le
c. troppo
c. ci
b. ne
(5) a. a lui
b. le
(6) a. lo
c. le
c. gli
b. ne
c. le

\section{Punti:}

\section{Completa.}

17 Io ho due fratelli e una sorella.

(1) sorella è più grande $\mathrm{e}$ sono più piccoli. Abitiamo insieme a Ferrara, dove studiamo.

(2) fratelli vivono in un paesino qua vicino.
(1) a. Mia
b. La mia
(2) a. miei
b. i miei
(3) a. I miei
c. Mio
c. mio
b. Miei
c. Genitori (3), invece,

18 1. Silvia in fisica.

2. Io e Paolo in questa città da meno di due anni.

3. Mio nonno per anni al giardinaggio.
1. a. si è laureata
2. a. abbiamo trasferito
3.
a. si è dedicato
b. è laureato
b. ci siamo trasferiti
b. ha dedicato
c. ti sei laureata
c. sono trasferiti
c. è dedicato

19 Quando io __ (1) piccolo, animali. Normalmente l'estate noi (2) in campagna e (3) molti (5) in montagna.
(1) a. sono stato
b. ero
c. avevo
(2) a. vivevo
b. sono vissuto
(3) a. ho avuto
c. sono andato
(4) a. passavamo
b. abbiamo passato
c. siamo passati
(5) a. andavamo
b. siamo andati
c. Andavano
b. aveva
(4) le vacanze al mare, ma una volta

20 Marco è alto di Carlo.
a. quanto
b. meno
c. come

21 È una città

a. in cui

b. che

c. ci siamo già stati.

22 Le vacanze 23 Scusa il ritardo, ma non la strada.
a. sono finite
b. hanno finito
c. l'ho finita

a. ho conosciuto

b. conoscevo

c. ho saputo 
24 Per arrivare a Firenze tre ore.
a. ci vogliono
b. ci vuole
c. si vuole

\section{Punti:}

\section{Qual è la risposta corretta?}

25 Lo chiamo o gli scrivo?

a. Scrivigli una mail!

b. Gli scrivi!

c. Chiamala!

\section{Completa.}

26 La cosa è andare in vacanza.
a. meglio
b. migliore
c. ottimo

27 Se va al mare, (1) le ore molto calde e

(2) sempre un cappello!
(1) a. evita
(2) a. metta
b. eviti
b. mette
c. evito
c. metti

\section{Completa con i verbi della lista.}

28 (1) che oggi non

(2) facile trovare un buon impiego. essere flessibili, avere dei buoni contatti e (4) anche un po' di fortuna. Io

(5) a lungo, ma finora senza risultati, quindi (6) che prima o poi (7) a vivere all'estero.

a. andrò - b. sia - c. ci vuole - d. bisogna - e. ho deciso - f. ho cercato - g. penso

29 Secondo me scambiare la propria casa quando si va in vacanza non (1) una buona idea. Una mia amica, invece, non è d'accordo con me. Lei pensa che questa (2) un'ottima cosa, senza dubbio più conveniente che (3) una casa. Lei crede poi che vivere in un appartamento di altre persone (4) essere più interessante che stare in uno anonimo in affitto.

a. sia - b. possa - c. è - d. affittare

\section{Completa.}

30 È entrata mentre il giornale.

31 L'ho conosciuto un viaggio.
a. leggevo
a. mentre
b. ho letto
b. durante
c. leggendo
c. nel 
32 Quando sei arrivato, stavo proprio per
a. andandomene
b. vada
c. andarmene

\section{Punti:}

\section{Completa.}

33 Non ha voluto niente perché mangiato prima.
a. aveva già
b. ha già
c. avendo già

$35 \mathrm{Al}$ suo posto si è rotta.
a. sarò stata
b. ero
c. sarei stata

34 Non gli hai detto niente? Ma certo che ho parlato.
a. glielo
b. gliene
c. le

36 Prestami la tua bicicletta.
a. È mia
b. La mia.
c. Mia.

37 Non credo che (1) ancora insieme; (2) che (3) qualche tempo fa.
(1) a. sono
(2)
a. penso
b. ho pensato
(3) a. si lascino
b. stiano
c. pensavo
b. si siano lasciati
c. si lascerebbero

$38 v \ll$ Cosa farete dopo che

$\Delta$ «Mah, io

(1) l'esame?»

- «Io, invece, ho intenzione

(2) di sicuro a casa.»
(1) a. avrete superato
b. supererete
c. avete superato
(2) a. mi sarò riposata
b. mi riposerò
c. mi ero riposata
(3) a. che faccio
b. di fare
c. che farò

(3) un bel viaggetto.»

39 Ma quanto tempo ci (1)? Il treno (2) per partire! Avevo paura che tu non
(3) in tempo!
(1) a. mettevi
b. metterai
c. hai messo
(2) a. sta
b. stava
c. stette
(3) a. arrivassi
b. fossi arrivata
c. arrivi

40 Sì, certo, Venezia è una delle più belle città che io (1); è però anche molto turistica $\mathrm{e}$ (2) da migliaia di persone. A me sembra che tu (3) gusti diversi dai miei. A patto che tu non (4) cambiato, beh, chiaro, puoi sempre (5).
(1) a. ho mai visto
b. vedessi mai
c. abbia mai visto

(2) a. venisse visitata

b. viene visitata

(3) a. abbia

c. sia visitata

b. hai

c. Avessi 

(4) a. sia
b. fossi
(5) a. andare
c. sei
b. andarne
c. andarci

Punti:

\section{In quali frasi si possono sostituire gli elementi sottolineati con «andando», senza cambiare il senso?}

41 a. Mentre andava a casa, Ada ha incontrato il figlio.

b. Mentre Ada andava a casa, il figlio ha incontrato Gianni.

c. Quando vado a casa, incontro sempre Ada.

d. Dopo esser andata a casa, ha incontrato Ada.

e. Prima di andare a casa, ha incontrato Ada.

\section{Collega le frasi.}

42 a. Se nevicasse,

b. Se questo libro ti piacesse,

c. Se tu lavorassi con più calma,

d. Se avesse studiato un po' di più,

e. Se vuoi,

f. Se in passato avessi lavorato di più,

1. oggi avrei meno problemi.

2. vengo a trovarti questo pomeriggio.

3 . te lo presterei volentieri.

4. andrei a sciare.

5. sarebbe stato promosso.

6. il tuo lavoro sarebbe più preciso.

\section{Completa con}

\section{... i pronomi.}

43 E col pallone, come va? - Beh,

(1) gioco ancora quasi tutte le domeniche.

Dopo un duro lavoro

(2) riposa volentieri.

Di questo problema___ (3) parla spesso anche in TV.

Regalando

(4) voleva farti una sorpresa.

(a) se ne - (b) telo - (c) ci si - (d) ci

\section{... le preposizioni.}

44 È noto ormai che uno dei problemi più gravi è oggi quello

(1) cambiamenti climatici.

Anche lo scenario disegnato (2) ONU, un aumento di 2-3 gradi (3) temperatura, è allarmante, perché farebbe anticipare lo scioglimento della neve (4) quasi un mese. Per la gente è dunque un problema prendere (5) considerazione l'ipotesi delle vacanze, sia in montagna (dove si assiste (6) un aumento di incidenti legati smottamento dei versanti alpini), sia al mare, dove (8) governare il tempo saranno sempre più gli «eventi estremi». (9) arco di un anno, cioè, avremo la stessa quantità d'acqua, ma in forma molto più violenta. Insomma, c'è serio! (10) preoccuparsi (11) 

(a) a - (b) a - (c) allo - (d) da - (e) dall' - (f) dei - (g) di - (h) di - (i) in - (l) nell' - (m)

\section{... i verbi.}

$45 v \ll$ Senti, $\tau \ll$ Sì, ma l' (1) per caso Il Corriere?» $v \ll$ E infatti 1 ' (2) via. Credevo che 1' $(3) ! »$ (4), solo che c'era un articolo che mi (5) e che conservare.»

$\tau \ll$ Mi dispiace. Vuoi che (7) a mia sorella? Penso che lo (8) anche lei.»

$v \ll$ No, no, (9) perdere, però per favore la prossima volta, prima di (10) via qualcosa (11) che me lo (12).»

(a) avessi letto - (b) avevo letto - (c) buttare - (d) chieda - (e) chiedessi - (f) compri - (g) hai visto -

(h) ho buttato - (i) interessava - (l) lascia - (m) preferirei - (n) volevo

\section{Lui disse ...?}
46 (1) «Qui mi trovo bene.» (2) «Penso che vada bene.»
(3) «Dovrei uscire alle 7.»
(4) «Esci subito dalla classe!»
(5) «Dovrò cambiarmi.»
(6) «È arrivato.»
(7) «Avevo paura.»
(8) «Mangiando si ingrassa.»
(9) «Sarei dovuto uscire.»
(10) «Se avessi mangiato saresti ingrassato.»

Lui disse che...
(1) a. lì si trovava bene.
b. lì si trova bene.
c. qui si trovava bene.
(2) a. pensava che andasse bene.
b. pensa che vada bene.
c. pensava che andava bene.
(3) a. dovrebbe uscire alle 7.
b. dovesse uscire alle 7. c. sarebbe dovuto uscire alle 7 .
(4) a. esca subito dalla classe.
b. uscisse subito dalla classe. c. usciva subito dalla classe.
(5) a. dovrà cambiarsi.
b. avrebbe dovuto cambiarsi.
c. dovesse cambiarsi.
(6) a. è arrivato.
b. sia arrivato.
c. era arrivato.
(7) a. aveva paura.
b. avesse paura.
c. abbia avuto paura.
(8) a. mangiasse si ingrassa.
b. mangiando si ingrassa.
c. avesse mangiato si ingrassa.
(9) a. dovrebbe uscire.
b. dovesse uscire.
c. sarebbe dovuto uscire.
(10) a. se avesse mangiato sarebbe ingrassato.
b. se mangiasse ingrasserebbe.
c. se avesse mangiato ingrasserebbe.

Punti: 
APÊNDICE F- Questionário respondido ao final do primeiro módulo do curso da São Francisco- USP

\section{AVALIAÇÃO DO CURSO ITALIANO PER GIURISTI- DIREITO USP}

1) As suas expectativas iniciais a respeito do curso de Italiano para Juristas foram alcançadas?

2) Qual a sua opinião sobre o livro "Italiano per giuristi”?

3) Quais suas impressões a respeito do livro "Espresso A1"?

4) Qual a atividade mais interessante que foi desenvolvida no curso?

5) Qual a atividade que você considera menos interessante do curso?

6) Quais os pontos positivos e os pontos negativos do curso?

7) $O$ que contribuiu mais para o desenvolvimento e aproveitamento do curso? A didática da professora, os livros adotados ou a sua própria dedicação pessoal?

8) Deixe suas críticas ou sugestões: 


\section{APÊNDICE G- Questionário respondido ao final do segundo módulo do curso da São Francisco- USP}

\section{CURSO DE ITALIANO PARA JURISTAS \\ QUESTIONÁRIO 2}

NOME:

E-mail:

1) Em relação às suas expectativas iniciais a respeito do "Corso di italiano per giuristi" qual nota você daria para o seu aproveitamento (de 0 a 5 ) em cada item mencionado? (Se o item não corresponder à sua expectativa inicial deixe em branco)

Conhecimento de língua e gramática italiana

Conhecimento sobre o sistema jurídico italiano

Preparação para prova de proficiência (mestrado e doutorado)

Preparação para fazer curso ou intercâmbio na Itália

Estudar o italiano jurídico (termos técnicos)

Reciclagem

2) Você acredita ter alcançado um melhor nível em:

Gramática

Compreensão de textos em geral (leitura)

Compreensão de textos jurídicos (leitura)

Compreensão oral (ascolto)

Conversação (diálogos)

( )

( )

3) O que poderia ter sido mais trabalhado durante o curso?

Gramática

Conversação

Leitura de textos jurídicos

Leitura de textos em geral

Escrita

Tradução

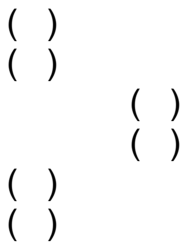

4) Qual a sua maior dificuldade no decorrer das aulas?

Compreensão oral (ascolto) ( )

Compreensão escrita (leitura)

Produção oral (diálogos)

Produção escrita (escrita)

5) Você teria interesse em continuar o curso?

$\operatorname{Sim}($ ) Não ( )

6) O tempo de curso foi suficiente PARA ATINGIR AS SUAS EXPECTATIVAS?

Sim ( )

Não ( )

Comente (opcional) 


\title{
APÊNDICE H - Termo de autorização do aluno do Curso de Italiano
}

\section{Para Juristas}

\author{
UNIVERSIDADE DE SÃO PAULO \\ FACULDADE DE FILOSOFIA, LETRAS E CIÊNCIAS HUMANAS
}

\section{AUTORIZAÇÃO \\ ALUNO - ITALIANO PARA JURISTAS}

$\mathrm{Eu}$, portador(a)

do documento de identidade $\mathrm{n}^{\mathrm{o}}$ aluno(a) do curso

"Italiano para juristas", ministrado por Quézea Regina Albolea Mastelaro, na Faculdade de Direito do Largo São Francisco, às , das $\mathrm{h}$ às $\mathrm{h}$, autorizo o uso do material produzido por mim, durante as aulas de língua italiana das quais participo como discente.

Declaro estar ciente de que esse material será usado para análise em uma pesquisa situada no âmbito do ensino-aprendizagem de italiano como língua estrangeira para juristas brasileiros e desenvolvida, sob orientação da professora Dra. Maria Cecilia Casini, por Quézea Regina Albolea Mastelaro, portadora do documento de identidade ำ 27.215.314-X, no USP 7305698, aluna do curso de Mestrado em Língua, Literatura e Cultura Italianas da Universidade de São Paulo. Assim sendo, autorizo a utilização do material exclusivamente para as finalidades da referida pesquisa.

São Paulo, de de 2013.

Ass. do(a) aluno(a) 


\section{ANEXOS}

ANEXO A- Trabalho apresentado por uma aluna do grupo de segunda-feira (primeiro módulo do curso da São Francisco)

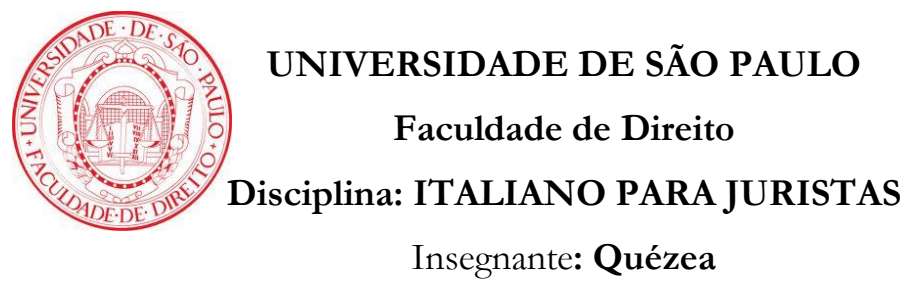

Orario: Lunedì -14 alle 17

Studentessa: ANA PAULA MAGNA DA SILVA FRASCA CASTELHANO

\section{La Costituzione della Repubblica litalianda}
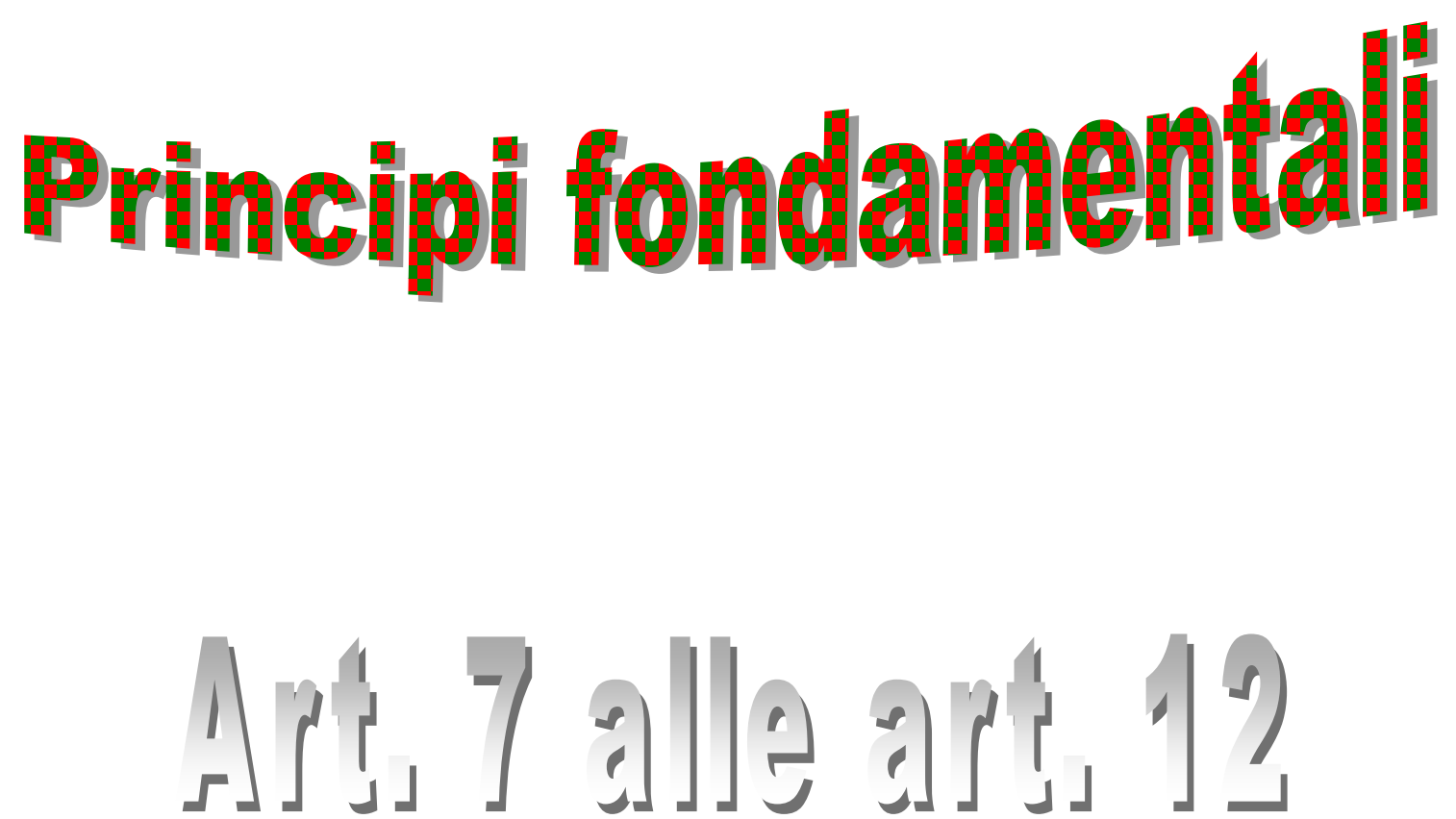


\section{INDICE}

INTRODUZIONE

LA COSTITUZIONE ITALIANA: COMMENTI GENERALI............................................................

PRINCIPI FONDAMENTALI DELLA COSTITUZIONE ITALIANA...........................................2

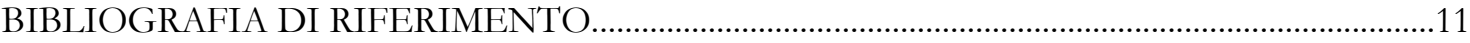




\section{INTRODUZIONE}

O presente trabalho tem como objetivo, explicitar de maneira breve comentários aos princípios fundamentais da Costituzione Italiana, quais sejam: art. $7^{\circ}$ ao $12^{\circ}$.

A Costiturione Italiana é um importante texto escrito que serviu de inspiração para muitas outras constituições no mundo, como a Constituição Federal brasileira de 1988.

Não se deseja esgotar o tema, tendo em vista a dimensão e importância dos mencionados artigos, que são a base fundamental da Costiturione Italiana.

Entender o mencionado diploma superior é entender também uma parcela do sistema de garantias constitucionais brasileiras, já que muito devemos e importamos da Costiturione Italiana.

Desde já agradeço a oportunidade de estudar o tema proposto que muito enriqueceu e despertou interesse para estudos de Direito Comparado futuros.

\section{LA COSTITUZIONE ITALIANA: COMMENTI GENERALI}

La Costituzione è l'insieme dei principi fondamentali che sono alla base dell'ordinamento giuridico di uno Stato, è quindi la legge fondamentale dello Stato.

Negli stati contemporanei si presenta sottoforma di documento scritto in quanto costituisce l'ordinamento giuridico, il cui scopo è quello di proclamare i diritti inviolabili dei cittadini e di porre un limite ai poteri dello Stato. Fa eccezione la Gran Bretagna che non ha una Costituzione scritta, ma le norme costituzionali rappresentano norme consuetudinarie in quanto sono leggi emanate in periodi storici diversi.

Il 2 giugno 1946 i cittadini furono chiamati a votare contemporaneamente per il referendum tra monarchia e repubblica e per l'Assemblea Costituente. Queste furono le prime elezioni della storia dell'Italia svolte a suffragio effettivamente universale. Il decreto del $1^{\circ}$ febbraio 1946 aveva infatti esteso finalmente il diritto di voto anche alle donne. Fra i 556 delegati dell assemblea sedevano i cosiddetti padri della Costituzione che dopo un anno e mezzo circa ( $1^{\circ}$ gennaio 1948$)$ elaborarono la Costituzione.

\section{PRINCIPI FONDAMENTALI DELLA COSTITUZIONE ITALIANA}

Se può dire che "Il testo della Costituzione venne quindi presentato come una sintesi delle aspirazioni popolari più diverse, echeggianti le antiche enunciazioni evangeliche e le recenti proposizioni del manifesto di Marx. I compilatori della Carta costituzionale riuscirono infatti a superare i dati egoistici di ogni ideologia per portarsi ad una visione ampia e disinteressata della comunità italica alla quale si intendeva fornire lo strumento per l'instaurazione di una società 
democratica, dove la libertà fosse alimentata dalla coscienza di precise responsabilità individuali e la solidarietà fosse sorretta dal buon diritto. Questa Costituzione insomma aveva il privilegio raro di nascere dalla chiara volontà dei rappresentanti del popolo italiano accomunati in un poderoso sforzo di dar tregua e sicurezza alla nazione dopo tanto travaglio di violenze ed inquietudini." (adaptado)

\section{Art. 7 \\ Lo Stato e la Chiesa cattolica sono, ciascuno nel proprio ordine, indipendenti e sourani. \\ I loro rapporti sono regolati dai Patti Lateranensi. Le modificazioni dei Patti accettate dalle due parti, non richiedono procedimento di revisione costituzionale.}

\section{Commenti art.7:}

“Ai tempi dello Statuto Albertino l'Italia era uno stato confessionale cioè aveva un'unica religione si Stato che era la religione cattolica.

I Padri costituenti vollero invece che l'Italia fosse uno stato laico riconoscendo alla Chiesa il potere religioso. Comunque il fatto che abbiano riservato alla Chiesa cattolica un articolo, ci fa capire che essa aveva un ruolo di grande importanza perché la stragrande maggioranza degli italiani erano cattolici e perché Roma è sede del Papato.

Nel c.2 viene stabilito che i rapporti tra lo stato e la Chiesa sono regolati dai Patti Lateranensi. Questi furono stipulati nel 1929 tra Mussolini e il Papa Pio XI per superare i conflitti che erano nati in seguito alla Breccia di Porta Pia del 1870 quando l'esercito piemontese invase Roma. Essi stabilivano:

- l'indipendenza del Papato al quale veniva attribuito un territorio (la Città del Vaticano), proprie guardie, una propria legislazione;

- obbligo insegnamento della religione cattolica in tutte le scuola;

- effetti civili del matrimonio religioso.

Per superare le contraddizioni tra art.7 e patti Lateranensi, nel 1984 venne stipulato un nuovo Concordato che prevedeva:

- insegnamento della religione cattolica facoltativo;

- matrimonio civile, religioso e concordatario.”47

${ }^{47} \mathrm{La}$ Costituzione Italiana Commentata. Disponível em:

$<$ http://www.itclucca.lu.it/documenti_alunnifamiglie/produzioni_alunni/analisi_articoli_costituzione_2Ia.pdf > Acesso em 26 de maio de 2013 


\begin{abstract}
Art. 8
Tutte le confessioni religiose sono egualmente libere davanti alla legge.

Le confessioni religiose diverse dalla cattolica hanno diritto di organizzarsi secondo i propri statuti, in quanto non contrastino con l'ordinamento giuridico italiano.

I loro rapporti con lo Stato sono regolati per legge sulla base di intese con le relative rappresentanze.
\end{abstract}

\title{
Commenti art. 7 e 8
}

"Questo il primo comma dell'art. 7, su cui la discussione dei costituenti fu lunga, laboriosa e a volte polemica. Comunque questa enunciazione che ricalcava l'antica formula cavouriana libera Chiesa in libero Stato riconfermava in qualche modo la distinzione tra i due enti, mentre tendeva a non riaprire una dolorosa pagina di lotta in un'Italia stanca e stremata. Furono così anche acquisiti al testo costituzionale i Patti Lateranensi del 1929 con il voto favorevole non solo dei democristiani, ma anche dei comunisti e delle destre. L'articolo precisa inoltre che le modificazioni dei suddetti Patti, "accettate dalle parti, non richiedono procedimenti di revisione costituzionale". L'articolo 8 recita: "Tutte le confessioni religiose sono ugualmente libere dinanzi alla legge": non sono eguali, dunque, ma egualmente libere, per il fatto che possono tutte essere liberamente professate e predicate sul territorio della Repubblica. La Chiesa Cattolica conserva in virtù dell'articolo 7 una posizione giuridica speciale, che, però, non limita la libertà fondamentale di culto che è uno dei principi insopprimibili di ogni libera società." $" 48$

L'art. 8 Cost. enuncia il principio della pari libertà delle confessioni religiose davanti alla legge e della loro autonomia rispetto allo Stato. L'art. 8 è da porre in connessione con l'art. 19, che tutela la libertà religiosa sia in forma individuale che associata. Le prescrizioni dell’art. 8, che parlano di "confessioni religiose", si concentrano in particolare sul momento associativo, garantendo l'autonomia organizzativa delle confessioni. Sotto questo profilo, l'art. 8 costituisce un richiamo del più generale principio pluralista di cui all'art. 2. (vedi sopra). Le norme degli statuti di organizzazioneinterna delle confessioni religiose non devono, però, contrastare conl'ordinamento giuridico. La Corte costituzionale, precisando il senso di questa disposizione, ha stabilendo che le clausole degli statuti non devono porsi in contrasto con i soli principi fondamentali dell'ordinamento nazionale (sent. 21 febbraio 1988, n. 43).

Rispetto agli enunciati dell'art. 8 , il precedente art. 7 contiene delle disposizioni speciali con riferimento ai rapporti tra lo Stato e la Chiesa cattolica, che sono regolati dai Patti Leteranensi del

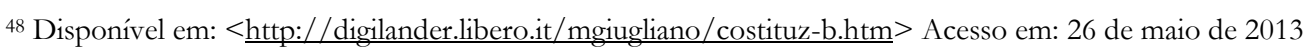


1929, anch'essi recepiti con legge (i Patti sono stati successivamente modificati dal Concordato del 1984). I Patti Lateranensi introducono una serie di privilegi per la Chiesa cattolica, fra cui:

a) l'insegnamento della religione cattolica nelle scuole pubbliche, cui peraltro non sono obbligati coloro che non intendono avvalersene (v. sul punto Corte cost., sent. 12 aprile 1989, n. 203);

b) il riconoscimento degli effetti civili per i matrimoni contratti secondo le norme del diritto canonico. I Patti Lateranensi introducono numerose deroghe alle norme e ai principi costituzionali, che sono considerate legittime perché fondate sull'art. 7 Cost. La giurisprudenza costituzionale ha tuttavia stabilito che il contenuto dei Patti non deve comunque urtare con i principi supremi della Costituzione (in ordine ai princi supremi, v. il capitolo sui limiti alla revisione costituzionale). ${ }^{49}$

"Nel c.1 viene sancito il principio del pluralismo religioso cioè il riconoscimento della libertà religiosa di ciascuno. Ma già nel c.2 viene sancito un primo limite all'esercizio delle religioni diverse dalla cattolica e cioè che non devono andare contro le leggi dello Stato italiano (ad. Es. in Italia è proibita ogni forma di menomazione fisica per cui non può essere praticata l'infibulazione).

Nel c.3 si stabilisce che se una religione diversa dalla cattolica vuole vedersi riconosciuti dei diritti, deve stipulare degli accordi con lo Stato italiano e l'iniziativa degli stessi deve partire dai rappresentanti delle religioni. Esempi di intese: Tavola valdese (1984), Avventisti del Settimo Giorno (1986), Comunità ebraica (1987).’50

Art. 9

La Repubblica promuove lo sviluppo della cultura e la ricerca scientifica e tecnica.

Tutela il paesaggio e il patrimonio storico e artistico della Narione.

\section{Commenti art. 9:}

Questo articolo fu ritenuto da taluni superfluo." ${ }_{51}$

"La Costituzione garantisce la massima libertà nella formazione e diffusione della cultura e nello svolgimento dell'attività di ricerca, in contrapposizione alla politica seguita dal fascismo che aveva

imposto la cultura di regime. Non dà però una definizione di cultura che va quindi rintracciata nell'art.33. Il c.2 è di estrema importanza perché contiene un concetto, quello di paesaggio, che ha subito nel corso del tempo una profonda evoluzione. In assemblea costituente con tale termine si indicava unicamente la

\footnotetext{
${ }^{49}$ Disponível em: <http://www.gpchironi.it/sitenew/attachments/054_Principi\%20fondamentali.COSTPDF.PDF> Acesso em: 26 de maio de 2013

${ }^{50} \mathrm{La}$ Costituzione Italiana Commentata. Disponível em:

$<$ http://www.itclucca.lu.it/documenti_alunnifamiglie/produzioni_alunni/analisi_articoli_costituzione_2Ia.pdf $>$ Acesso em 26 de maio de 2013

${ }^{51}$ Disponível em: < http://digilander.libero.it/mgiugliano/costituz-b.htm> Acesso em: 26 de maio de 2013
} 
conservazione delle bellezze naturali secondo quanto stabilito da una legge del 1938.

Oggi invece si intende un concetto molto più ampio di tutela del paesaggio che oggi prende il nome di tutela dell'ambiente. Secondo un principio dello sviluppo economico-sociale la rigenerazione delle risorse non deve compromettere l'ambiente delle generazioni future; comunque la legislazione riguardante la tutela dell'ambiente si è avuta solo in tempi recenti.

Nel 1966 è stata emanata la prima legge antismog che detta le norme dell'inquinamento e solo nel 1986 è stato istituito il Ministero dell'ambiente; soprattutto a partire dal 2000 che sono stati recepiti nel nostro ordinamento importanti provvedimenti comunitari per quanto riguarda l'inquinamento atmosferico." 52

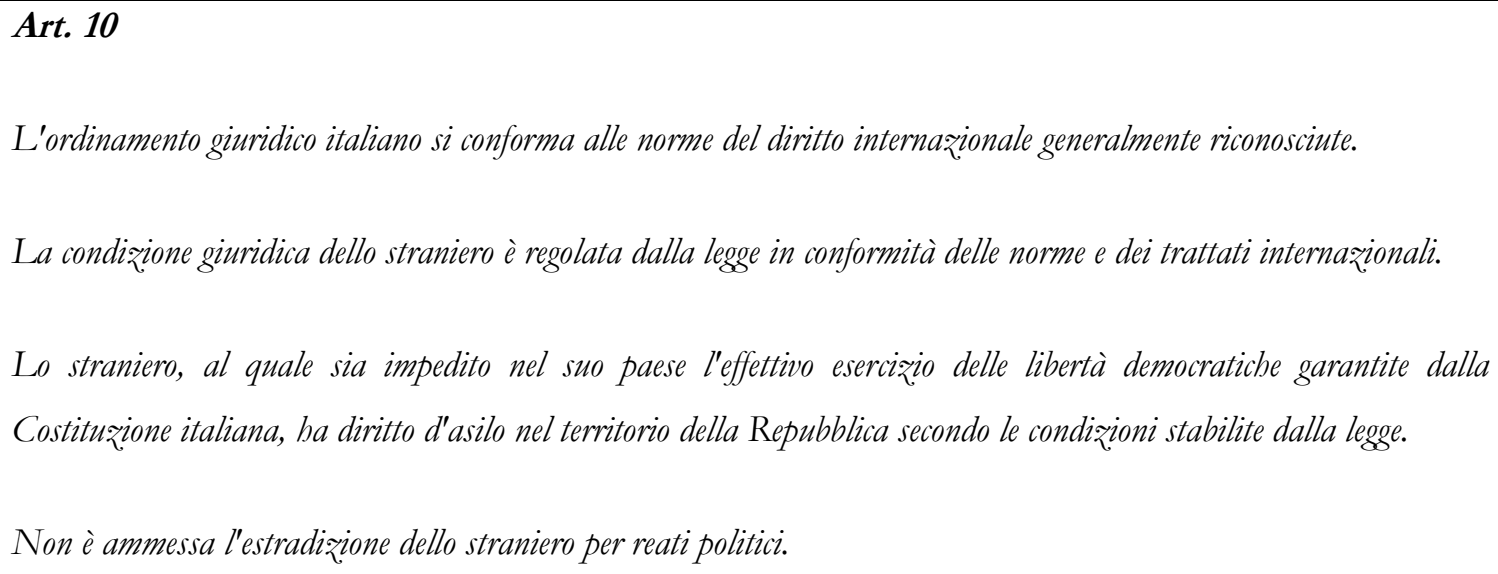

\section{Commenti art. 10:}

"Art. 10 - La Repubblica inserisce il suo ordinamento giuridico nel diritto internazionale come pure tratterà lo straniero in conformità alle norme dei trattati internazionali. Concede inoltre il diritto d'asilo nel suo territorio allo straniero, "al quale sia impedito nel suo paese l'effettivo esercizio delle libertà democratiche garantite dalla Costituzione italiana"; come pure non concede l'estradizione per reati politici." ${ }^{53}$

Secondo gran parte della dottrina e secondo la giurisprudenza costituzionale, il I comma dell'art. 10 Cost. contiene un principio implicante l'adattamento automatico del diritto italiano alle norme consuetudinarie dell'ordinamento internazionale. Le consuetudini internazionali, che come tali appartengono all'ordinamento internazionale e non al diritto interno, vengono immesse

\footnotetext{
${ }^{52}$ La Costituzione Italiana Commentata. Disponível em: $<$ http://www.itclucca.lu.it/documenti_alunnifamiglie/produzioni_alunni/analisi_articoli_costituzione_2Ia.pdf $>$ Acesso em 26 de maio de 2013

${ }^{53}$ Disponível em: < http://digilander.libero.it/mgiugliano/costituz-b.htm> Acesso em: 26 de maio de 2013
} 
nell'ordinamento italiano attraverso il richiamo dell'art.10. Questa disposizione non riguarda il recepimento dei trattati internazionali, per il quale l'art. 80 Cost. Prevede un'apposita disciplina. ${ }^{54}$

L'Italia ha aderito a trattati internazionali che, come la Convenzione europea per la salvaguardia dei diritti dell'uomo, proteggono i diritti fondamentali della persona umana in quanto tale, a prescindere dalla sua nazionalità.

Ad ogni modo, secondo parte della dottrina e alla luce di una certa giurisprudenza costituzionale, la titolarità dei diritti di libertà sanciti dalla stessa Costituzione, o almeno di alcuni fra di essi, non è limitata ai soli cittadini italiani, ma è da considerarsi estesa anche agli stranieri.

È necessario ricordare che speciali diritti sono riconosciuti ai cittadini stranieri comunitari. Infatti, il Trattato sulla Comunitàeuropea garantisce loro il diritto di circolare, lavorare e stabilirsi in tutti gli Stati membri dell'Unione. Sul piano dei diritti politici, il Trattato di Masstricht ha istituito una "cittadinanza dell'Unione", riconosciuta a tutti i cittadini degli Stati membri e che consente, fra l'altro, di I rapporti con il diritto internazionale e con gli ordinamenti a carattere sovranazionale votare ed essere eletti alle elezioni comunali e a quelle per il Parlamento europeo ai cittadini residenti in uno Stato membro diverso da quello di appartenenza.

Un'altra opinione: "Nel primo comma con la dicitura "L'ordinamento giuridico italiano si conforma alle norme del diritto internazionale generalmente riconosciute" i padri costituenti vollero intendere che le norme internazionali Che hanno una portata generale (norme consuetudinarie) valgono automaticamente all'interno dell'ordinamento giuridico italiano. Con questa norma costituzionale, inoltre, lo stato italiano si impegna a non adottare leggi di contrasto con le norme del diritto internazionale, a considerare incostituzionali quelle leggi che non rispettassero tale principio e a ratificare i trattati internazionali.

Nel secondo comma viene determinata la condizione giuridica dello straniero che è regolata dalla legge in conformità delle norme e dei trattati internazionali.

Nel nostro ordinamento esistono attualmente due categorie di stranieri: i cittadini dell'Unione europea che godono di una tutela e di garanzie simili a quelle del cittadino italiano; i cittadini extracomunitari, non appartenenti all'Unione europea, che possono essere soggetti a restrizioni per quanto riguarda l'ingresso e la permanenza nel nostro paese. Non esiste una legge specifica per la questione degli stranieri ma l'unica che stabilisce diritti e doveri dello straniero è la Legge Bossi-Fini del 2002. Essa prevede che l'espulsione, emessa in via amministrativa dal Prefetto

${ }^{54}$ Disponível em: <http://www.gpchironi.it/sitenew/attachments/054_Principi\%20fondamentali.COSTPDF.PDF> Acesso em: 26 de maio de 2013 
della Provincia dove viene rintracciato lo straniero clandestino, sia immediatamente eseguita con l'accompagnamento alla frontiera da parte della forza pubblica. Gli immigrati clandestini, privi di validi documenti di identità, vengono portati in centri di permanenza temporanea, istituiti dalla Legge Turco-Napolitano, al fine di essere identificati. La legge prevede il rilascio del permesso di soggiorno, della residenza e cittadinanza italiana alle persone che dimostrino di avere un lavoro o un reddito sufficienti per il loro mantenimento economico. A questa regola generale si aggiungono i permessi di soggiorno speciali e quelli in applicazione del diritto di asilo. La norma ammette $\mathrm{i}$ respingimenti al Paese di origine in acque extraterritoriali, in base ad accordi bilaterali fra Italia e Paesi limitrofi, che impegnano le polizie dei rispettivi Paesi a cooperare per la prevenzione dell'immigrazione clandestina.

Nel terzo e nel quarto comma, la Repubblica italiana garantisce a tutti i cittadini stranieri, ai quali siano stati negati i diritti e le libertà democratiche nei loro paesi, di poter esercitare tali diritti nel territorio dello stato italiano, grazie al diritto di asilo.

L'ultimo comma prevede che nel nostro paese non sia ammessa l'estradizione dello straniero per reati politici. Lo Stato italiano rifiuta l'estradizione, cioè il rimandare la persona al paese d'origine, di un cittadino straniero che sia ricercato per reati politici commessi in opposizione a regimi antidemocratici, nei quali vengono attuate politiche persecutorie nei confronti dei diritti umani. Viene escluso dal novero dei reati politici il delitto di genocidio, per il quale è prevista l'estradizione sia per lo straniero che per il cittadino. (v.L. cost. del 21 giugno 1967, n.1 - Estradirione per i delitti di genocidio.." ${ }^{55}$

\section{Art. 11}

L'Italia ripudia la guerra come strumento di offesa alla libertà degli altri popoli e come mezzo di risoluzione delle controversie internazionali; consente, in condizioni di parità con gli altri Stati, alle limitazioni di sovranità necessarie ad un ordinamento che assicuri la pace e la giustizia fra le Nazioni; promuove e favorisce le organizzazioni internazionali rivolte a tale scopo.

\section{Commenti art.11:}

\footnotetext{
${ }^{55}$ La Costituzione Italiana Commentata. Disponível em: $<$ http://www.itclucca.lu.it/documenti_alunnifamiglie/produzioni_alunni/analisi_articoli_costituzione_2Ia.pdf $>$ Acesso em 26 de maio de 2013
} 
"Art. 11 - Questo articolo nacque dal bisogno di temperare le esuberanze belliciste o nazionaliste che avevano caratterizzato vent'anni della nostra storia e della nostra politica internazionale ${ }^{56}$.

'L'Italia ripudia la guerra come strumento di offesa alla libertà degli altri popoli e come mezzo di risoluzione delle controversie internazionali”; consente, in condizioni di parità con gli altri stati, e in caso di necessità, sempre per il trionfo della giustizia tra gli uomini, anche limitaz̧ione di sovranità; promuove e favorisce tutte quelle organizzazioni internazionali che sono rivolte alla conservazione della pace nel mondo."

L'art. 11 Cost. era stato originariamente pensato dal Costituente italiano in vista dell'imminente adesione dell'Italia alle Nazioni Unite. Ma nella giurisprudenza costituzionale ha conosciuto maggiore fortuna con riferimento ai rapporti tra l'Italia l'ordinamento comunitario. L'art. 11 ha infatti fornito il fondamento costituzionale per il trasferimento di sovranità a favore della Comunità e dell’Unione europea (v. Capitolo sulle fonti comunitarie). ${ }^{57}$

Un altro commenti: "L'articolo 11 oppone un netto rifiuto alla guerra e soprattutto apre un nuovo capitolo, quello di una cultura di pace da diffondere e costruire anche attraverso organismi internazionali.

Proprio nel periodo in cui è stato elaborato il testo costituzionale, l'Organizzazione delle naz̧ioni unite (Onu) stava muovendo i suoi primi passi: l'essenza dell'articolo 11 riflette proprio la speranza che l'Italia potesse essere inclusa tra i paesi “amanti della pace”, così come previsto dallo statuto dell'Onu, e potesse essere ammessa a far parte dell'Organizzazione stessa, obiettivo che è stato raggiunto nel 1955.

L'Italia, pertanto, in base all'articolo 11 e come membro dell'Onu, non ricorrerà alle armi per risolvere eventuali contrasti con gli altri stati e non invaderà mai il territorio altrui, violando la libertà di altri popoli.

Sempre in base a tale articolo, viene anche sancito il divieto di intervenire militarmente in aiuto di un altro stato che lotti, nel proprio territorio, contro un movimento di liberazione nazionale (ad esempio: il movimento separatista basco in Spagna)." 58

\footnotetext{
56 Disponível em: < http://digilander.libero.it/mgiugliano/costituz-b.htm $>$ Acesso em: 26 de maio de 2013

${ }^{57}$ Disponível em: < http://www.gpchironi.it/sitenew/attachments/054_Principi\%20fondamentali.COSTPDF.PDF> Acesso em: 26 de maio de 2013

${ }^{58}$ La Costituzione Italiana Commentata. Disponível em:

$<$ http://www.itclucca.lu.it/documenti_alunnifamiglie/produzioni_alunni/analisi_articoli_costituzione_2Ia.pdf $>$ Acesso em 26 de maio de 2013
} 
Quindi l'unico tipo di guerra ammesso è la legittima difesa per respingere un attacco armato che minacci l'esistenza e l'indipendenza dell'Italia (vedi art. 52 della Costituzione).

Art. 12

La bandiera della Repubblica è il tricolore italiano: verde, bianco e rosso, a tre bande verticali di eguali dimensioni." $" 59$

Commenti art.12:

"Art. 12 - "La bandiera della Repubblica è il tricolore italiano", quale fu adottato fin dal lontano 1797 e per tutto il Risorgimento: "verde, bianco e rosso, a tre bande verticali di eguali dimensioni". "60

"Il tricolore italiano venne decretato il 7 gennaio del 1797 a Reggio Emilia come bandiera della Repubblica Cispadana. Durante il regno d'Italia fu aggiunto al tricolore lo stemma sabaudo poi eliminato con l'istituzione della repubblica. Viene ripresa perché era la bandiera del regno d'Italia e venne ammainata definitivamente il 25 aprile 1945, con lo scioglimento dal giuramento per militari e civili, quale ultimo atto del governo di Benito Mussolini. Il tricolore rappresenta l'Italia in qualsiasi manifestazione e anche all'estero." 61

\footnotetext{
${ }^{59}$ Disponível em: < http://www.governo.it/Governo/Costituzione/principi.html> Acesso em: 26 de maio de 2013 ${ }^{60}$ Disponível em: <http://digilander.libero.it/mgiugliano/costituz-b.htm> Acesso em: 26 de maio de 2013

${ }^{61}$ La Costituzione Italiana Commentata. Disponível em:

$<$ http://www.itclucca.lu.it/documenti_alunnifamiglie/produzioni_alunni/analisi_articoli_costituzione_2Ia.pdf $>$ Acesso em 26 de maio de 2013
} 


\section{BIBLIOGRAFIA DI RIFERIMENTO}

Costituzione Italiana. Disponível em:

<http://www.governo.it/Governo/Costituzione/principi.html> Acesso em: 26 de maio de 2013

La Costituzione Italiana Commentata. Disponível em:

$<$ http://www.itclucca.lu.it/documenti_alunnifamiglie/produzioni_alunni/analisi_articoli_costituzi one_2Ia.pdf> Acesso em 26 de maio de 2013

Principi Fondamentali della Costituzione Italiana. Disponível em:

<http://digilander.libero.it/mgiugliano/costituz-b.htm> Acesso em: 26 de maio de 2013

Principi Fondamentali della Costituzione Italiana. Disponível em:

<http://www.gpchironi.it/sitenew/attachments/054_Principi\%20fondamentali.COSTPDF.PDF> Acesso em: 26 de maio de 2013 


\section{ANEXO B- Trabalho apresentado por um aluno do grupo de sábado (primeiro módulo do curso da São Francisco)}

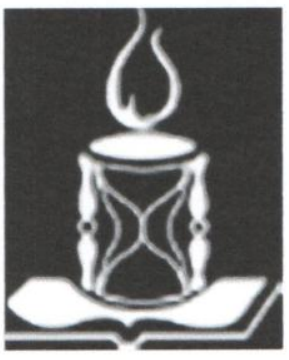

UNIVERSIDADE DE SÃO PAULO FACULDADE DE FILOSOFIA, LETRAS E CIÊNCIAS HUMANAS SERVIÇO DE CULTURA E EXTENSÃO UNIVERSITÁRIA

Curso de Italiano para Juristas (oferecido aos alunos da Faculdade de Direito) Coordenação: $\operatorname{Prof}^{\mathrm{a}} \mathrm{Dr}^{\mathrm{a}}$ Angela Maria Tenorio Zucchi Ministrante: Prof ${ }^{a}$ Quézea Regina Albolea Turma 2 - Sábado

SEMINÁRIO: "IL PRINCIPIO DI CAPACITÀ CONTRIBUTIVA NEL DIRITTO TRIBUTARIO ITALIANO" 


\section{TEXTO DOUTRINÁRIO ORIGINAL ${ }^{1}$ E RESPECTIVA TRADUÇÃO}

\begin{tabular}{|c|c|}
\hline Texto original & Tradução \\
\hline $\begin{array}{l}\text { Il principio di capacità contributiva (art. } \\
53 \text { Cost.) }\end{array}$ & $\begin{array}{l}\text { O princípio da capacidade contributiva } \\
\text { (art. 53, da Constituição) }\end{array}$ \\
\hline $\begin{array}{l}\text { L'art. } 53,1^{\circ} \text { comma, della Costituzione } \\
\text { dispone che "Tutti sono tenuti a concorrere } \\
\text { alle spese pubbliche in ragione della loro } \\
\text { capacità contributiva". }\end{array}$ & $\begin{array}{l}\text { O art. } 53 \text {, parágrafo } 1^{\circ} \text {, da Constituição } \\
\text { dispõe que "todos devem concorrer para a } \\
\text { despesa pública em função de sua } \\
\text { capacidade contributiva". }\end{array}$ \\
\hline $\begin{array}{l}\text { Questa "direttiva sostanziale" che il texto } \\
\text { costituzionale rivolge al legislatore tributario } \\
\text { è stato ed è uno dei principali temi di studio, } \\
\text { di confronto e di scontro dottrinale, sicchè } \\
\text { molto ampia è la letteratura giuridica in } \\
\text { argomento. }\end{array}$ & $\begin{array}{l}\text { Esta "diretiva fundamental" que o texto } \\
\text { constitucional dirige ao legislador tributário } \\
\text { foi e é um dos principais temas de estudo, de } \\
\text { confronto e de discussão doutrinal, de } \\
\text { maneira que a literatura jurídica sobre o } \\
\text { assunto é muito ampla. }\end{array}$ \\
\hline $\begin{array}{l}\text { La trattazione dello stesso deve perciò } \\
\text { essere limitata alle principali questioni, nel } \\
\text { seguente ordine sintetico. }\end{array}$ & $\begin{array}{l}\text { Por essa razão, o tratamento do tema será } \\
\text { limitado às suas principais questões, nas } \\
\text { disposições sintetizadas na sequência. }\end{array}$ \\
\hline $\begin{array}{l}\text { Comunemente in dottrina si ritiene che il } \\
\text { principio presenti due profili generali ossia } \\
\text { quello "solidaristico" e quello "garantistico" } \\
\text { (Fanzozzi, Falsitta, Lupi, Tesauro, Russo, } \\
\text { Fedele). }\end{array}$ & $\begin{array}{l}\text { Na doutrina, geralmente, considera-se } \\
\text { que o princípio em questão apresenta dois } \\
\text { aspectos gerais: um relacionado ao } \\
\text { solidarismo e outro referente à sua natureza } \\
\text { garantista (Fanzozzi, Falsitta, Lupi, Tesauro, } \\
\text { Russo, Fedele). }\end{array}$ \\
\hline $\begin{array}{l}\text { Il primo deriva essenzialmente dalla } \\
\text { prima parte della norma, laddove si } \\
\text { generalizza l'obbligo ("tutti sono tenuti") } \\
\text { del concorso alle esigenze finanziarie } \\
\text { pubbliche. }\end{array}$ & $\begin{array}{l}\text { O primeiro aspecto deriva essencialmente } \\
\text { do texto inicial da norma ("todos devem"), } \\
\text { em que se generaliza a obrigação de } \\
\text { participação no financiamento dos gastos } \\
\text { públicos. }\end{array}$ \\
\hline $\begin{array}{l}\text { Tale obbligo viene concordemente } \\
\text { ritenuto una specificazione dei doveri di } \\
\text { solidarietà imposti dall'art. } 2 \text { della } \\
\text { Costituzione medesima e non è, dunque, } \\
\text { collegato agli effetti delle spese finanziate. } \\
\text { Vi è pure concordanza dottrinale } \\
\text { nell'affermare peraltro che l'obbligo } \\
\text { medesimo incontra il limite del c.d. "minimo } \\
\text { vitale" ossia dell'intassabilità dei redditi }\end{array}$ & $\begin{array}{l}\text { Tal obrigação é unanimemente } \\
\text { considerada como um desdobramento dos } \\
\text { deveres de solidariedade impostos pelo art. } \\
2^{\circ} \text { da própria Constituição e não é, portanto, } \\
\text { vinculada aos efeitos das despesas } \\
\text { financiadas. Apesar disso, também há } \\
\text { consenso doutrinário em afirmar que a } \\
\text { mesma obrigação é limitada pelo chamado } \\
\text { "mínimo vital", ou seja pela não }\end{array}$ \\
\hline
\end{tabular}

' MANZON, Enrico; Modolo, Adriano. Manuale Breve Diritto Tributario. Giuffrè Editore, 2008, pp. 20-23. Disponível em <

>. Acesso em: 01 jun.2013. 


\begin{tabular}{|c|c|}
\hline "minimi" (Falsitta, Tesauro, Lupi). & $\begin{array}{l}\text { tributabilidade dos rendimentos "mínimos" } \\
\text { (Falsitta, Tesauro, Lupi). }\end{array}$ \\
\hline $\begin{array}{l}\text { Sul piano oggettivo, tuttavia la seconda } \\
\text { parte della disposizione de qua prevede che } \\
\text { il "concorso" avvenga "in ragione della... } \\
\text { capacità contributiva", così ponendo un } \\
\text { limite all"obbligo stesso. }\end{array}$ & $\begin{array}{l}\text { No plano objetivo, no entanto, a segunda } \\
\text { parte do dispositivo em questão prevê que a } \\
\text { participação deve ocorrer "em razão da... } \\
\text { capacidade contributiva", estabelecendo, } \\
\text { assim, um limite para a própria obrigação. }\end{array}$ \\
\hline $\begin{array}{l}\text { La gran parte dei contrasti dottrinali verte } \\
\text { sull"esatta configurazione di tale limite. }\end{array}$ & $\begin{array}{l}\text { A maior parte das divergências } \\
\text { doutrinárias relaciona-se com a exata } \\
\text { configuração deste limite. }\end{array}$ \\
\hline $\begin{array}{l}\text { In linea di massima possono individuarsi } \\
\text { due tendenze, sostanzialmente contrapposte: }\end{array}$ & $\begin{array}{l}\text { De modo geral, podem identificar-se duas } \\
\text { correntes, substancialmente contrapostas: }\end{array}$ \\
\hline $\begin{array}{l}\text { - l'una, più "garantista", che afferma che } \\
\text { il limite va inteso nel senso che l'obbligo } \\
\text { tributario deve essere direttamente collegato } \\
\text { ad un indice rivelatore di ricchezza (quali ad } \\
\text { es. Il reddito, il patrimonio etc.), a sua volta } \\
\text { direttamente collegabile al soggetto } \\
\text { obbligato (Falsitta); }\end{array}$ & $\begin{array}{l}\text { - Uma, mais "garantista", afirma que o } \\
\text { limite deve ser entendido no sentido de que } \\
\text { a obrigação tributária deve estar diretamente } \\
\text { ligada a um indicador revelador de riqueza } \\
\text { (como, por exemplo, a renda, o patrimônio } \\
\text { etc), que, por sua vez, deve estar diretamente } \\
\text { vinculado ao sujeito obrigado (Falsitta); }\end{array}$ \\
\hline $\begin{array}{l}\text { - l'altra, più "solidarista", che invece } \\
\text { sostiene un'accezione più lata del limite, } \\
\text { inteso quale mero criterio, razionale, di } \\
\text { riparto (Fedele). }\end{array}$ & $\begin{array}{l}\text { - Outra, mais "solidarista", ao contrário } \\
\text { da anterior, defende uma interpretação mais } \\
\text { ampla do limite, entendido como um mero } \\
\text { critério racional de repartição (Fedele). }\end{array}$ \\
\hline $\begin{array}{l}\text { In sintesi, il primo orientamento } \\
\text { concepisce la capacità contributiva quale } \\
\text { limite assoluto alla discrezionalità del } \\
\text { legislatore tributario; la seconda la intende } \\
\text { quale limite relativo (Fantozzi). }\end{array}$ & $\begin{array}{l}\text { Em resumo, a primeira abordagem } \\
\text { concebe a capacidade contributiva como } \\
\text { limite absoluto à discricionariedade do } \\
\text { legislador tributário; a segunda, entende-a } \\
\text { como limite relativo (Fantozzi). }\end{array}$ \\
\hline $\begin{array}{l}\text { Tra i due fondamentali indirizzi teorici } \\
\text { esiste un punto, generale, di concordanza } \\
\text { ossia che "capacità contributiva" è concetto } \\
\text { equivalente a quello di "capacità } \\
\text { economica"; che perciò le manifestazioni } \\
\text { ("indici") di capacità contributiva devono } \\
\text { essere economicamente misurabili. Con il } \\
\text { corollario che essi possono essere sia indici } \\
\text { diretti (es: reddito, patrimonio) sia indici } \\
\text { indiretti (es: consumi; trasferimenti di beni; } \\
\text { Tesauro). }\end{array}$ & $\begin{array}{l}\text { Entre as duas principais orientações } \\
\text { teóricas existe um ponto comum, de } \\
\text { concordância: ambas acreditam que o } \\
\text { conceito de "capacidade contributiva" é } \\
\text { equivalente ao de "capacidade econômica"; } \\
\text { e que, por essa razão, as manifestações } \\
\text { ("indicadores") da capacidade contributiva } \\
\text { devem ser economicamente mensuráveis. } \\
\text { Com a consequência de que eles podem ser } \\
\text { tanto indicadores diretos (exemplo: renda, } \\
\text { patrimônio) quanto indicadores indiretos } \\
\text { (exemplo: consumo, transmissão de bens; } \\
\text { Tesauro). }\end{array}$ \\
\hline $\begin{array}{l}\text { Tuttavia, la discordanza dottrinale si ri- } \\
\text { evidenzia immediatamente appena diventa }\end{array}$ & $\begin{array}{c}\text { Entretanto, a discordância doutrinária } \\
\text { volta a se evidenciar imediatamente, quando }\end{array}$ \\
\hline
\end{tabular}




\begin{tabular}{|c|c|}
\hline $\begin{array}{l}\text { necessario stabilire quali "indici" di capacità } \\
\text { contributiva possano essere prescelti dal } \\
\text { legislatore per attuare il criterio di riparto de } \\
\text { quo; in sostanza, quali situazioni di fatto } \\
\text { possano legittimare, costituzionalmente, } \\
\text { l'imposizione di un tributo. }\end{array}$ & $\begin{array}{l}\text { se torna necessário estabelecer quais } \\
\text { "indicadores" da capacidade contributiva } \\
\text { podem ser escolhidos pelo legislador para } \\
\text { realizar-se o critério de repartição em } \\
\text { questão; em suma, quais situações de fato } \\
\text { podem legitimar, constitucionalmente, a } \\
\text { imposição de um tributo. }\end{array}$ \\
\hline $\begin{array}{l}\text { Secondo le concezioni più restrittive, solo } \\
\text { determinate situazioni fattuali sono idonee a } \\
\text { costituire indice di capacità contributiva e lo } \\
\text { sono solo quelle che hanno un concreto, } \\
\text { ancorchè indiretto, valore economico di } \\
\text { scambio (quindi, appunto, il reddito, il } \\
\text { patrimonio, il consumo); secondo quelle } \\
\text { meno restrittive, può rivelare idoneità alla } \\
\text { contribuzione qualsiasi fatto economico, } \\
\text { purchè sia astrattamente valutabile in } \\
\text { termini monetari, ancorché sia mera } \\
\text { espressione di "potenzialità economica". }\end{array}$ & $\begin{array}{l}\text { Segundo os entendimentos mais } \\
\text { restritivos, somente determinadas situações } \\
\text { factuais são adequadas a constituir } \\
\text { indicadores da capacidade contributiva e o } \\
\text { são apenas aquelas que têm um real, mesmo } \\
\text { que indireto, valor econômico de troca (por } \\
\text { esta razão, precisamente, a renda, o } \\
\text { patrimônio, o consumo); já de acordo com } \\
\text { as concepções menos restritivas, pode } \\
\text { revelar adequação para a contribuição } \\
\text { qualquer fato econômico, desde que seja } \\
\text { abstratamente avaliável em termos } \\
\text { monetários, mesmo que seja mera expressão } \\
\text { de "potencialidade econômica". }\end{array}$ \\
\hline $\begin{array}{l}\text { La Corte costituzionale da diverso tempo } \\
\text { è orientata in questo secondo senso, avendo, } \\
\text { più volte ed ormai costantemente, affermato } \\
\text { che la scelta degli "indici di capacità } \\
\text { contributiva" è oggetto di determinazione } \\
\text { discrezionale da parte del legislatore, con } \\
\text { l'unico limite, peraltro generalissimo, della } \\
\text { "ragionevolezza". La Corte di conseguenza } \\
\text { ha privilegiato l'aspetto "oggettivo" della } \\
\text { capacità contributiva, intesa come } \\
\text { manifestazione di "forza economica" (ex } \\
\text { pluribus C. Cost. 156-155/2001, 229/1999, } \\
\text { 7/1999; Falsitta). }\end{array}$ & $\begin{array}{l}\quad \text { A Corte Constitucional há algum tempo } \\
\text { tem se orientado neste segundo sentido, } \\
\text { tendo, por várias vezes e agora } \\
\text { continuamente, afirmado que a escolha dos } \\
\text { "indicadores da capacidade contributiva" é } \\
\text { objeto de determinação discricionária por } \\
\text { parte do legislador, com o único limite, } \\
\text { embora muito geral, da "razoabilidade". A } \\
\text { Corte, consequentemente, tem privilegiado o } \\
\text { aspecto "objetivo" da capacidade } \\
\text { contributiva, entendendo-a como } \\
\text { manifestação do "poder econômico" (ex } \\
\text { pluribus C. Cost. 156-155/2001, 229/1999, } \\
\text { 7/1999; Falsitta). }\end{array}$ \\
\hline $\begin{array}{l}\text { Questioni connesse, sono poi quelle } \\
\text { relative all'effettività ed all'attualità della } \\
\text { capacità contributiva. }\end{array}$ & $\begin{array}{l}\quad \text { São ainda questões relacionadas ao } \\
\text { assunto aquelas referentes à efetividade e à } \\
\text { atualidade da capacidade contributiva. }\end{array}$ \\
\hline $\begin{array}{l}\text { La prima si pone, ad esempio, in } \\
\text { relazione alle ricostruzioni presuntive legali } \\
\text { della base imponibile di un tributo, sempre } \\
\text { più frequenti e finanziariamente rilevanti } \\
\text { (es: "redditometro"; studi di settore). }\end{array}$ & $\begin{array}{l}\text { A primeira (relativa à efetividade) } \\
\text { coloca-se, por exemplo, em relação às } \\
\text { composições das presunções legais da base } \\
\text { de cálculo de um tributo, cada vez mais } \\
\text { frequentes e financeiramente relevantes } \\
\text { (exemplo: "medidor de renda"; estudos } \\
\text { setoriais). }\end{array}$ \\
\hline
\end{tabular}




\begin{tabular}{|c|c|}
\hline $\begin{array}{l}\text { La seconda, essenzialmente, si pone a } \\
\text { riguardo delle norme impositrici, anche di } \\
\text { "interpretazione autentica", retroattive ed ai } \\
\text { "prelievi anticipati" (la retroattività delle } \\
\text { norme "procedimentali" è pacificamente } \\
\text { ammessa sia in dottrina sia nella } \\
\text { giurisprudenza di legittimità, trattandosi di } \\
\text { norme di "applicazione immediata"; } \\
\text { Tesauro). }\end{array}$ & $\begin{array}{l}\text { Sobre a segunda (referente à atualidade) } \\
\text { discute-se, basicamente, a respeito das } \\
\text { normas impositivas retroativas, ainda que de } \\
\text { "interpretação autêntica", e das "retenções } \\
\text { antecipadas" (a retroatividade das normas } \\
\text { "procedimentais" é pacificamente aceita, } \\
\text { tanto pela doutrina como pela } \\
\text { jurisprudência, tratando-se de normas de } \\
\text { "aplicação imediata"; Tesauro). }\end{array}$ \\
\hline $\begin{array}{l}\text { Anche in ordine a tali, più specifiche } \\
\text { "angolazioni" del principio di capacità } \\
\text { contributiva, si è espressa la giurisprudenza } \\
\text { costituzionale, sancendo che: }\end{array}$ & $\begin{array}{l}\text { Também em relação ao tema, as mais } \\
\text { distintas "perspectivas" do princípio da } \\
\text { capacidade contributiva são expressadas } \\
\text { pela jurisprudência constitucional, } \\
\text { afirmando que: }\end{array}$ \\
\hline $\begin{array}{l}\text { - le presunzioni legali in materia } \\
\text { tributaria non confliggono, in linea di } \\
\text { massima, con il principio di capacità } \\
\text { contributiva, ma devono consentire al } \\
\text { contribuente la possibilità di prova contraria } \\
\text { (C. Cost 103/1991); }\end{array}$ & $\begin{array}{l}\text { - as presunções legais em matéria } \\
\text { tributária não conflituam, de maneira geral, } \\
\text { com o princípio da capacidade contributiva, } \\
\text { mas devem permitir ao contribuinte a } \\
\text { possibilidade de apresentar prova em sentido } \\
\text { contrário (C. Cost } 103 / 1991) \text {; }\end{array}$ \\
\hline $\begin{array}{l}\text { - l'imposizione retroattiva, anche } \\
\text { eventualmente in via di "interpretazione } \\
\text { autentica", di per sè non contrasta con il } \\
\text { principio costituzionale de quo, sotto il } \\
\text { profilo dell' "attualità", purchè "non sia } \\
\text { spezzato il rapporto" tra l'una e l'altro, in } \\
\text { particolare per il decorso di un tempo } \\
\text { eccessivo. Ipotesi che per la Corte va esclusa } \\
\text { allorchè tra la norma retroattiva ed i fatti- } \\
\text { indice di idoneità alla contribuzione sia } \\
\text { passato un lasso di tempo così breve da } \\
\text { rendere addirittura "prevedibile" la norma } \\
\text { stessa (C. Cost. 14/1995, 315/1994). }\end{array}$ & $\begin{array}{l}\text { - a imposição retroativa, mesmo nos } \\
\text { casos de "interpretação autêntica", por si } \\
\text { própria não contrasta com o princípio } \\
\text { constitucional em questão, sob a perspectiva } \\
\text { da "atualidade", desde que "não seja } \\
\text { rompida a relação" entre uma e outro } \\
\text { (imposição e princípio da capacidade } \\
\text { contributiva), especialmente pelo decurso de } \\
\text { um tempo excessivo. Assim, não será } \\
\text { rompida a relação, segundo a Corte, quando } \\
\text { entre a norma retroativa e o fato indicador } \\
\text { da idoneidade da contribuição tenha } \\
\text { transcorrido um lapso de tempo muito breve, } \\
\text { suficiente para tornar realmente "previsível" } \\
\text { a referida norma (C. Cost. 14/1995, } \\
\text { 315/1994). }\end{array}$ \\
\hline $\begin{array}{l}\text { È peraltro pacificamente riconosciuta in } \\
\text { dottrina la necessità, giuridico- } \\
\text { costituzionale, che le scelte legislative circa } \\
\text { l'individuazione dei presupposti di } \\
\text { tassazione corrispondano al generale } \\
\text { principio di uguaglianza formale (art. } 3,1^{\circ} \\
\text { comma, Cost.), anche quale } \\
\text { "ragionevolezza" intrinseca della legge } \\
\text { tributaria, al quale il principio di capacità } \\
\text { contributiva si raccorda e nel quale si }\end{array}$ & $\begin{array}{l}\text { Além disso, é pacificamente reconhecida } \\
\text { na doutrina a necessidade, jurídico- } \\
\text { constitucional, de que as escolhas } \\
\text { legislativas sobre a individualização dos } \\
\text { pressupostos de tributação satisfaçam ao } \\
\text { princípio geral da igualdade formal (art. } 3 \text {, } \\
\text { parágrafo } 1^{\circ} \text {, da Constituição), também } \\
\text { relacionado à "razoabilidade" intrínseca da } \\
\text { lei tributária, e ao qual o princípio da } \\
\text { capacidade contributiva se conecta e se }\end{array}$ \\
\hline
\end{tabular}




\begin{tabular}{|c|c|}
\hline $\begin{array}{l}\text { compenetra (De Mita, Fantozzi, Tesauro, } \\
\text { Lupi, Fedele, Falsitta). }\end{array}$ & $\begin{array}{l}\text { permeia (De Mita, Fantozzi, Tesauro, Lupi, } \\
\text { Fedele, Falsitta). }\end{array}$ \\
\hline $\begin{array}{l}\text { Soprattutto sotto tale profilo si registra } \\
\text { un' ampia giurisprudenza costituzionale, } \\
\text { essendo il binomio degli artt. 3-53, Cost., } \\
\text { uno dei più "gettonati" parametri di } \\
\text { costituzionalità delle norme tributarie } \\
\text { primarie. In argomento tuttavia la Corte non } \\
\text { ha fatto altro che ribadire, ed applicare alla } \\
\text { specifica materia fiscale, i propri } \\
\text { orientamenti in tema di "uguaglianza- } \\
\text { ragionevolezza". }\end{array}$ & $\begin{array}{l}\text { Sobretudo sob tal perspectiva registra-se } \\
\text { uma ampla jurisprudência constitucional, } \\
\text { sendo o binômio dos artigos } 3 / 53 \text {, da } \\
\text { Constituição, um dos mais predominantes } \\
\text { parâmetros de constitucionalidade das } \\
\text { normas tributárias primárias. Entretanto, em } \\
\text { tese, a Corte nada mais faz do que repetir e } \\
\text { aplicar à matéria fiscal específica, as } \\
\text { próprias orientações sobre o tema da } \\
\text { "igualdade/razoabilidade". }\end{array}$ \\
\hline $\begin{array}{l}\text { La Corte costituzionale stessa inoltre, con } \\
\text { giurisprudenza consolidata } a b \\
\text { immemorabili, ha escluso l'applicabilità del } \\
\text { principio di capacità contributiva alle tasse, } \\
\text { in quanto tributi "commutativi" e non, } \\
\text { appunto, "contributivi" (C. Cost. 119/1969, } \\
\text { 23/1968). }\end{array}$ & $\begin{array}{l}\text { Adicionalmente, a Corte Constitucional, } \\
\text { com jurisprudência consolidada há muito } \\
\text { tempo, exclui a aplicabilidade do princípio da } \\
\text { capacidade contributiva em relação às taxas, } \\
\text { por se tratarem de tributos "comutativos" e } \\
\text { não exatamente "contributivos" (C. Cost. } \\
119 / 1969,23 / 1968) \text {. }\end{array}$ \\
\hline $\begin{array}{l}\text { Tale orientamento non è condiviso dalla } \\
\text { dottrina prevalente (Tesauro, Fedele, } \\
\text { Falsitta, Lupi; in senso adesivo, invece, De } \\
\text { Mita, Russo). }\end{array}$ & $\begin{array}{l}\text { Tal orientação não é compartilhada pela } \\
\text { doutrina predominante (Tesauro, Fedele, } \\
\text { Falsitta, Lupi; em sentido diverso, De Mita, } \\
\text { Russo). }\end{array}$ \\
\hline $\begin{array}{l}\text { Al principio di capacità contributiva è } \\
\text { correlato il principio di progressività cui il } \\
\text { sistema tributario, nel suo complesso, deve } \\
\text { essere informato (art. } 53,2^{\circ} \text { comma, Cost.). }\end{array}$ & $\begin{array}{l}\text { Ao princípio da capacidade contributiva } \\
\text { agrega-se o princípio da progressividade, } \\
\text { pelo qual o sistema tributário, em geral, } \\
\text { deve ser informado (art. } 53 \text {, parágrafo } 2^{\circ} \text {, da } \\
\text { Constituição). }\end{array}$ \\
\hline $\begin{array}{l}\text { La portata normativa di tale principio, se } \\
\text { di norma "programmatica" ovvero } \\
\text { "precettiva", è controversa in dottrina (per la } \\
\text { prima tesi, Fantozzi, Falsitta, Lupi; per la } \\
\text { seconda, Fedele, Tesauro, Russo). }\end{array}$ & $\begin{array}{l}\text { A carga normativa deste princípio, se de } \\
\text { norma programática ou preceptiva, é } \\
\text { controvertida na doutrina (pela primeira } \\
\text { tese, Fantozzi, Falsitta, Lupi; pela segunda, } \\
\text { Fedele, Tesauro, Russo). }\end{array}$ \\
\hline $\begin{array}{l}\text { Vi è peraltro concordanza di vedute in } \\
\text { dottrina circa la concreta, quasi, } \\
\text { impossibilità giuridica di censurare } \\
\text { d'incostituzionalità, per difetto di } \\
\text { "progressività", una singola legge } \\
\text { d'imposta. }\end{array}$ & $\begin{array}{l}\text { Apesar disso, há consenso do ponto de } \\
\text { vista doutrinário sobre a quase certa } \\
\text { impossibilidade jurídica de se considerar } \\
\text { inconstitucional uma lei singular que verse } \\
\text { sobre um imposto, por desrespeito à } \\
\text { progressividade. }\end{array}$ \\
\hline $\begin{array}{l}\text { In tal ultimo senso è comunque } \\
\text { consolidata, "da sempre", la giurisprudenza } \\
\text { costituzionale (C. Cost. 128/1966). }\end{array}$ & $\begin{array}{l}\text { Seja como for, a jurisprudência } \\
\text { constitucional também está consolidada, há } \\
\text { muito tempo, no mesmo sentido (C. Cost. } \\
\text { 128/1966). }\end{array}$ \\
\hline
\end{tabular}




\section{RESUMO DO TEXTO DOUTRINÁRIO ORIGINAL E RESPECTIVA TRADUÇÃO}

\begin{tabular}{|c|c|}
\hline Resumo do texto original & Tradução do resumo \\
\hline $\begin{array}{l}\text { Il principio di capacità contributiva (art. } \\
53 \text { Cost.) }\end{array}$ & $\begin{array}{l}\text { O princípio da capacidade contributiva } \\
\text { (art. 53, da Constituição) }\end{array}$ \\
\hline $\begin{array}{l}\text { L'art. } 53,1^{\circ} \text { comma, della Costituzione } \\
\text { dispone che "Tutti sono tenuti a concorrere } \\
\text { alle spese pubbliche in ragione della loro } \\
\text { capacità contributiva". }\end{array}$ & $\begin{array}{l}\text { O art. } 53 \text {, parágrafo } 1^{\circ} \text {, da Constituição } \\
\text { dispõe que "todos devem concorrer para a } \\
\text { despesa pública em função de sua } \\
\text { capacidade contributiva". }\end{array}$ \\
\hline $\begin{array}{l}\text { Comunemente in dottrina si ritiene che il } \\
\text { principio presenti due profili generali ossia } \\
\text { quello "solidaristico" e quello } \\
\text { "garantistico". }\end{array}$ & $\begin{array}{l}\text { Na doutrina, geralmente, considera-se } \\
\text { que o princípio em questão apresenta dois } \\
\text { aspectos gerais: um relacionado ao } \\
\text { solidarismo e outro referente à sua natureza } \\
\text { garantista. }\end{array}$ \\
\hline $\begin{array}{l}\text { Il primo deriva essenzialmente dalla } \\
\text { prima parte della norma, laddove si } \\
\text { generalizza l'obbligo del concorso alle } \\
\text { esigenze finanziarie pubbliche. }\end{array}$ & $\begin{array}{l}\text { O primeiro aspecto deriva essencialmente } \\
\text { do texto inicial da norma, em que se } \\
\text { generaliza a obrigação de participação no } \\
\text { financiamento dos gastos públicos. }\end{array}$ \\
\hline $\begin{array}{l}\quad \text { Tale obbligo viene concordemente } \\
\text { ritenuto una specificazione dei doveri di } \\
\text { solidarietà imposti dall'art. } 2 \text { della } \\
\text { Costituzione. Vi è pure concordanza } \\
\text { dottrinale nell'affermare peraltro che } \\
\text { l'obbligo incontra il limite del "minimo } \\
\text { vitale". }\end{array}$ & $\begin{array}{l}\text { Tal obrigação é unanimemente } \\
\text { considerada como um desdobramento dos } \\
\text { deveres de solidariedade impostos pelo art. } \\
2^{\circ} \text { da Constituição. Apesar disso, também há } \\
\text { consenso doutrinário em afirmar que a } \\
\text { obrigação é limitada pelo "mínimo vital". }\end{array}$ \\
\hline $\begin{array}{l}\text { Sul piano oggettivo, tuttavia la seconda } \\
\text { parte della disposizione de qua prevede che } \\
\text { il "concorso" avvenga "in ragione della... } \\
\text { capacità contributiva", così ponendo un } \\
\text { limite all"obbligo stesso. }\end{array}$ & $\begin{array}{l}\text { No plano objetivo, no entanto, a segunda } \\
\text { parte do dispositivo em questão prevê que a } \\
\text { participação deve ocorrer "em razão da... } \\
\text { capacidade contributiva", estabelecendo, } \\
\text { assim, um limite para a própria obrigação. }\end{array}$ \\
\hline $\begin{array}{l}\text { La gran parte dei contrasti dottrinali verte } \\
\text { sull"esatta configurazione di tale limite. }\end{array}$ & $\begin{array}{l}\text { A maior parte das divergências } \\
\text { doutrinárias relaciona-se com a exata } \\
\text { configuração deste limite. }\end{array}$ \\
\hline $\begin{array}{l}\text { In linea di massima possono individuarsi } \\
\text { due tendenze, sostanzialmente contrapposte: }\end{array}$ & $\begin{array}{l}\text { De modo geral, podem identificar-se duas } \\
\text { correntes, substancialmente contrapostas: }\end{array}$ \\
\hline $\begin{array}{l}\text { - l'una, più "garantista", che afferma che } \\
\text { il limite va inteso nel senso che l'obbligo } \\
\text { tributario deve essere direttamente collegato } \\
\text { ad un indice rivelatore di ricchezza, a sua } \\
\text { volta direttamente collegabile al soggetto } \\
\text { obbligato; }\end{array}$ & $\begin{array}{l}\text { - Uma, mais "garantista", afirma que o } \\
\text { limite deve ser entendido no sentido de que } \\
\text { a obrigação tributária deve estar diretamente } \\
\text { ligada a um indicador revelador de riqueza, } \\
\text { que, por sua vez, deve estar diretamente } \\
\text { vinculado ao sujeito obrigado; }\end{array}$ \\
\hline
\end{tabular}




\begin{tabular}{|c|c|}
\hline $\begin{array}{l}\text { - l'altra, più "solidarista", che sostiene } \\
\text { un'accezione più lata del limite, inteso quale } \\
\text { mero criterio, razionale, di riparto. }\end{array}$ & $\begin{array}{l}\text { - Outra, mais "solidarista", defende uma } \\
\text { interpretação mais ampla do limite, } \\
\text { entendido como um mero critério racional } \\
\text { de repartição. }\end{array}$ \\
\hline $\begin{array}{l}\text { Tra i due fondamentali indirizzi teorici } \\
\text { esiste un punto, generale, di concordanza } \\
\text { ossia che "capacità contributiva" è concetto } \\
\text { equivalente a quello di "capacità } \\
\text { economica". }\end{array}$ & $\begin{array}{l}\quad \text { Entre as duas principais orientações } \\
\text { teóricas existe um ponto comum, de } \\
\text { concordância: ambas acreditam que o } \\
\text { conceito de "capacidade contributiva" é } \\
\text { equivalente ao de "capacidade econômica". }\end{array}$ \\
\hline $\begin{array}{l}\text { Tuttavia, la discordanza dottrinale si ri- } \\
\text { evidenzia appena diventa necessario stabilire } \\
\text { quali "indici" di capacità contributiva } \\
\text { possano essere prescelti dal legislatore. }\end{array}$ & $\begin{array}{l}\quad \text { Entretanto, a discordância doutrinária } \\
\text { volta a se evidenciar, quando se torna } \\
\text { necessário estabelecer quais "indicadores" } \\
\text { da capacidade contributiva podem ser } \\
\text { escolhidos pelo legislador. }\end{array}$ \\
\hline $\begin{array}{l}\text { Secondo le concezioni più restrittive, solo } \\
\text { determinate situazioni fattuali sono idonee a } \\
\text { costituire indice di capacità contributiva e lo } \\
\text { sono solo quelle che hanno un concreto } \\
\text { valore economico; secondo quelle meno } \\
\text { restrittive, può rivelare idoneità alla } \\
\text { contribuzione qualsiasi fatto economico, } \\
\text { purchè sia astrattamente valutabile in } \\
\text { termini monetari. }\end{array}$ & $\begin{array}{l}\quad \text { Segundo os entendimentos mais } \\
\text { restritivos, somente determinadas situações } \\
\text { factuais são adequadas a constituir } \\
\text { indicadores da capacidade contributiva e o } \\
\text { são apenas aquelas que têm um real valor } \\
\text { econômico; já de acordo com as concepções } \\
\text { menos restritivas, pode revelar adequação } \\
\text { para a contribuição qualquer fato } \\
\text { econômico, desde que seja abstratamente } \\
\text { avaliável em termos monetários. }\end{array}$ \\
\hline $\begin{array}{l}\text { La Corte costituzionale da diverso tempo } \\
\text { è orientata in questo secondo senso, avendo } \\
\text { affermato che la scelta degli "indici" è } \\
\text { oggetto di determinazione discrezionale da } \\
\text { parte del legislatore, con l'unico limite della } \\
\text { "ragionevolezza". }\end{array}$ & $\begin{array}{l}\quad \text { A Corte Constitucional há algum tempo } \\
\text { tem se orientado neste segundo sentido, } \\
\text { tendo afirmado que a escolha dos } \\
\text { "indicadores" é objeto de determinação } \\
\text { discricionária por parte do legislador, com o } \\
\text { único limite da "razoabilidade". }\end{array}$ \\
\hline $\begin{array}{l}\text { Questioni connesse, sono poi quelle } \\
\text { relative all'effettività ed all'attualità della } \\
\text { capacità contributiva. }\end{array}$ & $\begin{array}{l}\text { São ainda questões relacionadas ao } \\
\text { assunto aquelas referentes à efetividade e à } \\
\text { atualidade da capacidade contributiva. }\end{array}$ \\
\hline $\begin{array}{l}\text { La prima si pone, ad esempio, in } \\
\text { relazione alle ricostruzioni presuntive legali } \\
\text { della base imponibile di un tributo. }\end{array}$ & $\begin{array}{l}\text { A primeira coloca-se, por exemplo, em } \\
\text { relação às composições das presunções } \\
\text { legais da base de cálculo de um tributo. }\end{array}$ \\
\hline $\begin{array}{l}\text { La seconda, essenzialmente, si pone a } \\
\text { riguardo delle norme impositrici retroattive. }\end{array}$ & $\begin{array}{l}\text { Sobre a segunda discute-se, basicamente, } \\
\text { a respeito das normas impositivas retroativas. }\end{array}$ \\
\hline $\begin{array}{l}\text { Anche in ordine a tali, più specifiche } \\
\text { "angolazioni" del principio, si è espressa la } \\
\text { giurisprudenza costituzionale, sancendo che: }\end{array}$ & $\begin{array}{l}\text { Também em relação ao tema, as mais } \\
\text { distintas "perspectivas" do princípio são } \\
\text { expressadas pela jurisprudência } \\
\text { constitucional, afirmando que: }\end{array}$ \\
\hline
\end{tabular}


- le presunzioni legali in materia tributaria non confliggono con il principio di capacità contributiva, ma devono consentire al contribuente la possibilità di prova contraria;

- l'imposizione retroativa di per sè non contrasta con il principio, purchè "non sia spezzato il rapporto" tra l'una e l'altro, in particolare per il decorso di un tempo eccessivo.

È peraltro pacificamente riconosciuta in dottrina la necessità che le scelte legislative circa l'individuazione dei presupposti di tassazione corrispondano al principio di uguaglianza formale.

La Corte costituzionale stessa inoltre ha escluso l'applicabilità del principio di capacità contributiva alle tasse, in quanto tributi "commutativi".

Tale orientamento non è condiviso dalla dottrina prevalente.
- as presunções legais em matéria tributária não conflituam com o princípio da capacidade contributiva, mas devem permitir ao contribuinte a possibilidade de apresentar prova em sentido contrário;

- a imposição retroativa por si própria não contrasta com o princípio, desde que "não seja rompida a relação" entre uma e outro, especialmente pelo decurso de um tempo excessivo.

Além disso, é pacificamente reconhecida na doutrina a necessidade de que as escolhas legislativas sobre a individualização dos pressupostos de tributação satisfaçam ao princípio da igualdade formal.

Adicionalmente, a Corte Constitucional exclui a aplicabilidade do princípio da capacidade contributiva em relação às taxas, por se tratarem de tributos "comutativos".

Tal orientação não é compartilhada pela doutrina predominante. 


\section{REFERÊNCIAS BIBLIOGRÁFICAS}

BABYlon (2013). Dicionário Italiano Português. Disponível em < >. Acesso em: 01 jun.2013.

HoEpli.it (2013). Dizionario Itaniano. Disponível em < >. Acesso em: 02 jun.2013.

Manzon, Enrico; Modolo, Adriano. Manuale Breve Diritto Tributario. Giuffrè Editore, 2008, pp. 20-23. Disponível em <

>. Acesso em: 01 jun.2013.

MYMEMORY (2013). MyMemory Translated.net. Disponível em <

>. Acesso em: 04 jun.2013.

Polito, André Guilherme. Michaelis - Dicionário Escolar Italiano. São Paulo: Melhoramentos, 2011. Disponível em $<$

$>$. Acesso em: 01 jun.2013.

Repubblica italiana. Corte Costituzionale. Disponível em <

$>$. Acesso em: 02 jun. 2013 .

VERBI ITALIANI (2013). Verbi italiani: coniugazione verbi regolari e coniugazione verbi irregolari italiani. Disponível em < $>$. Acesso em: 01 jun.2013. 


\section{ANEXO C- Alguns resumos do grupo de sábado (segundo módulo do curso da São Francisco)}

Resumo 1- AlunaTamiris Micheletti Britzki

RIASSUNTO

Primo capitolo della prima Parte del Libro

\section{IL DIRITTO CIVILE NELLA LEGALITÀ COSTITUZIONALE SECONDO IL SISTEMA ITALO-COMUNITARIO DELLE FONTI \\ Pietro Perlingieri}

\section{DIRITTO, GIUDICI E POLITICA}

Pietro parla delle inquietudini del civilista contemporaneo per il compito di trasmettere il concetti e categorie generali del diritto. Appunta la necessità della scienze giuridiche comunicare le inquitudini e le interrogativi insieme con le realtà sociale e culturale del mondo giuridico. Per esempio, è utile discorrere di diritto senza tener conto della crisi e delle lungaggini del processo?

Anche non basta la conoscenza della legge, l'interpertazione della dispozione legislativa, nè ricostruire il sistema com il fato, la realtà sociale, i problemi concreti. Gli studenti devono impegnarsi nella disputa per acquisire la capacità critico-argomentativa e gli operatori del diritto devono interpretare la legge.

Pietro parla della filosofia e di suo confronto con i civilisti. La ragion d'essere del diritto e della norma sono la coesistenza degli individui nella società e pertanto il diritto e la legge nòn può essere pensati separati dei soggeti e dei società.

La filosofia nel diritto è presente nel ordenamento vigente, però per Pietro, è necessario comprendere quale filosofia è presente per l'interpretazione giuridica. Per Lui, la teoria filosofica del'ordinamento non può essere astratta e generale; essa deve corrispondere al momento storico-giuridico e al vigente principio di legalità.

Lui tratta anche della finalità pratiche della scienza giuridica e della educazione del giurista. La finalità pratica del diritto è presente per il confronto dialetico tra norma e fato che sono posti in pratica per i legali, per i tribunali e per i notai. Pertanto, se è necessario fare leggi adeguate è altrettanto necessario formare giusti che abbiano la sensibilità di interpretare. Questa interpretazioni dell'ordinamento giuridico nòn deve essere unilaterali e deve essere considerata la stessa autonomia colletiva in conformità ai princípi fondamentali dell'ordinamento.

Per finire Pietro parla della crisi dello Stato sociale di diritto. Questa crisi è la cultura sulla quale si fonda lo Stato di diritto, che non pùo essere considerato storicamente antitetico a quello Stato sociale perche lo Stato di diritto si caratterizza per la separazione dei poteri (legislativo, amministrativo e giudiziario) e lo Stato sociale si caratterizza per il tentativo di coniugare legalità e giustizia sociale. 
Altrimenti: caso contrário

GLOSSÁRIO

Atteggiamenti: atitudes

Compito: dever, tarefa

Compiuto: completo

Consapevolezza: consciência

Esigono: exigência

Innanzi: em frente, à frente

Irriducibilità: impossível de ser modificado

Lungaggini: lentidão

Punti fermi: pontos chaves

Raffronto: comparação

Rinsaldare: fortalecer

Rinunciatari: renuciativas, derrotistas, perdedoras

Scettici: céticas

\section{Resumo 2- Aluno Rafael Ribeiro Meirelles Costa}

\section{RIASSUNTO DEL CAPITOLO PRIMO: DIRITTO GIUDICI E POLITICA}

Nel testo "Diritto e Politica, Metodi e Scuole" sono analizzati aspetti dell'attualità della scienza del Diritto.

Il primo capo abborda le inquietudini del civilista contemporaneo, ma si può affermare che quelle preocupazioni sono proprie di tutti i giuristi. La complessità delle forme giuridiche e le mutazioni nella società conducono ad una revizione della scienza e della cultura giuridiche.

Quindi il Diritto non può tenersi lontano della realtà sociale. Nelle parole del autore del testo: "I quatro termini indicati (soggeti, individui, norma e società) configurano una problematica unitaria, la ragione stessa del diritto" (p. 7).

Il testo distaca anche il ruolo della filosofia nel Diritto come della scienza sociale, tutte e due fondamentali per un'interpretazione pluraliste delle norme giuridiche in contrasto con la forma particolarista.

Secondo l'autore, lo Stato Sociale vive una crise associata a la dipendenza dalle prestazioni pubbliche, che generano la burocrazia e la corruzione. Una uscita 
possibile ed il rafforzamento dei meccanismi di responsabilità degli agenti dello Stato. Per finire, l'autore trata dei problemi del Giudiziario.

\section{ANEXO D- Alguns resumos do grupo de segunda-feira (segundo módulo do curso da São Francisco)}

Resumo 1- Aluno João Paulo Braune Guerra

\section{RIASSUNTO \\ IL DIRITTO CIVILE NELLA LEGALITÀ COSTITUZIONALE SECONDO IL SISTEMA ITALO-COMUNITARIO DELLE FONTI}

(Pietro Perlingieri)

\section{DIRITTO, GIUDICI E POLITICA}

\section{Inquietudini del civilista contemporaneo}

Le inquietudini del civilista contemporaneo è per il compito di introdure alle scienze il concetti generali del diritto in mezzo a la crise del liberalismo e dell'individualismo dentro dei globalizazione dell'economia e la crise della stabilità del diritto. È un compito piu complesso e difficile per 5 ragioni: l'irriducibilità dell'introduzione allo studio del diritto; la crise della distinzione del diritto privato e pubblico; la maggiore consapevolezza del giurista; il rapido mutamento delle condizioni sociali e della legislazione e la pluralità delle fonti giuridiche e la loro complessità.

\section{Scienza giuridica e cultura giuridica}

Perlingiere parla della scienza giuridica, che si caratteriza per il confronto dialettico tra norma e fato e della cultura giuridica, che è, dunque, fruto dell'attività interpretativa di tutti gli operatori del diritto e che è tanto quella dottrinale quanto quella giurisprudenziale.

\section{Filosofi e civilista a confronto: la filosofia nel diritto}

L'incontro del filosofo e del civilista è necessario, poi la norma non può essere compresa fuori della società, pertanto, è necessario unire teoria, del filosofo e pratica, del civilista. La filosofia nel diritto è presente nel ordenamento vigente e l'applicazione della legge lei impone nuove filosofie però è necessario comprendere quale filosofia è presente per l'interpretazione giuridica. 


\section{Finalità pratiche della scienza giuridica e educazione del giurista}

La finalità pratica del diritto è il confronto dialetico tra norma e fato che sono posti in pratica per i legali e per i tribunali. Le scienze giuridica deve essere applicata dai giudici con la sensibilità di interpretare l'ordinamento giuridico in accordo con la realtà. Pertanto, l'attività del giurista se avvale di una cultura ampia e di una conoscenza globale dell'ordinamento.

1- Interpretazioni unilaterali della giuridicità: il particolarismo come forza degenerativa del pluralismo.

L'interpretazione del giurista non può essere unilaterale. Il particolarismo degenera il pluralismo, che è un principio fondamentali dell'ordinamento che assicura l'autonomia collettiva, senza la quale non si può vivere.

\section{2- Crisi dello Stato sociale di diritto}

Lo Stato sociale rappresenta il tentativo di coniugare legalità e giustizia sociale. Lo Stato di diritto si caratterizza per la separazione dei poteri (legislativo, amministrativo e giudiziario) e, pertanto, non pùo essere considerato storicamente antitetico a quello Stato sociale. Lo Stato sociale ha avuto attuazione distorta e parziale, caratterizzata dalla proliferazione caotica di leggi speciali e dalla dilatazione del potere amministrativo (burocrazia). La crise è smarrimento culturale la cultura dei doveri non è difusa e ciò ha causato la crise dello Stato sociale.

\section{Centralità della questione giudiziaria}

L'ordine giudiziaria non sempre è coerente col metodo e con la ideologia utilizzati nella formazione universitaria. Il dibattito è: mancanza di coerenza tra premesse storicoideologiche e proposte concrete; spregiudicatezza nelle operazioni di trasformismo culturale; notevole intolleranza dogmatica verso le idee altrui; individuazione dei grande problemi e mancanza de adeguata sensibilità circa la priorità dei problemi.

\section{GLOSSÁRIO}

Connessioni: conexões

Innanzi: em frente

Rinsaldare: fortalecer

Smarrimento: perda

Spregiudicatezza: falta de escrúpulos

Utenti: usuários 


\section{Resumo 2- Aluno Henrique Mussio Fornazier Volpini}

\section{RIASSUNTO}

Il Diritto Civile Nella Legalità Costituzionale Secondo Il Sistema Italo-Comunitario Delle Fonti, Parte Prima: Diritto e Politica, Metodi e Scuole.

Autore Pietro Perlingieri

\section{Capitolo Primo \\ Diritto giudici e politica}

Nella prima parte di questo capitolo l'autore parla della inquietudini del civilista contemporaneo. Basicamente l'autore parla che la distinzione tradizionale tra il Diritto pubblico e il Diritto privato sta in crisi e che il Diritto non sta inseguendo l'evoluzione dell'economia e della società, per questo il compito del civilista di introdurre gli studente alle scienze giuridiche è più complesso di ieri.

Dopo l'autore parla che la interpretazione della cultura giuridica per gli operattori del diritto bisogna non solo della conoscenza delle legge, ma anche della conoscenza della realtà sociale e dei problemi concreti.

Nella parte tre del testo il tema è il confronto tra filosofi e civilisti. In questa parte l'autore parla che la norma giuridica può solo essere capita nel contesto della società e dei soggetti plurale. La ragion d'essere del diritto e della norma è la coesistenza degli individui nella società. Anche in questa parte l'autore scrive che è molto importante per gli operattori del diritto notare la filosofia che è presente nel ordinamento vigente e gli altre fonti del diritto per aplicare la norma giuridica. La aplicazione dela norma giuridica non deve essere astrata e generale, ma deve corrispondere al momento storicogiuridico.

Pietro trata nella parte quattro della finalità pratica della scienza giuridica e educazione del giurista. Per l'autore il diritto è una scienza pratica e per questo l'atività del giurista non dipende solamente di un strumentario rigido, ma anche di una cultura ampia, di una conoscenza globale dell'ordinamento e dall'analise del fatto concreto.

Per finire, Pietro parla della interpretazione unilaterali della giuridicità, critica il formalismo e parla del particolarismo come una forza degenarativa del diritto della colletività (parte cinque). In parte sei, Pietro scrive a rispetto della crise dello Stato sociale di Diritto, modelo di stato che cerca la garanzia dei diritti sociali (instruzione, salute, lavoro ed ambiente). Le ragioni de questa crisi sono assegnati alla doutrina, alla magistratura ed a legislatori.

\section{Glossario}

Pregnante normativa - Legislação significativa

Avvertono - advertir

Spinta - impulso

Lungaggini - atrasos

Innanzi - primeiro

Ruolo - papel

Consapevolezza - consciência

Spazia - faixas

Adoperate - utilizadas 
Scorgere - notar

Schiacciata - esmagado

Ravvisare - reconhecer

Respingendo - rejeitando

Smarrita - perdido

\title{
Resumo 3- Aluna Lara Espolaor Veronese
}

\section{VALUTAZIONE \\ CORSO DI ITALIANO PER GIURISTI $2^{\circ}$ LIVELLO}

\begin{abstract}
Alunna: Lara Espolaor Veronese
Data: 18/11/2013

Riassunto del testo: "Diritto e politica, metodi e scuole - Capitolo primo: Diritto giudici e politica", pp. 3-16.
\end{abstract}

Il testo letto spiega la nozione de scienza giuridica e il lavoro del interprete della norma giuridica. Secondo l'autore, Pietro Perlingieri, il dovere del civilista é introdurre gli studenti alle scienzi guiridiche. Questo compito è piú complesso per molti ragioni, ad exempio il rapido mutamento tanto delle condizioni sociali, dei costomi, degli stili di vita, quanto della legislazione ed in particolare dei valori fondamentali dell'ordinamento guiridico. La Costituzione Italiane, per exempio, ha avuto molti modificazione, e nell'ani 2000 é caracterizata per una normativazione comunitaria e federalista.

Secondo l'autore la scienza giuridica ha il rischio de insegnar per gli studenti nelle aule dell'università un diritto ben distinto da quello loro conosceranno nella prassi. Il diritto riflette la cultura di una determinata società che siano un iniverso di solucioni per i probleme quotidiano. Così l'attività interpretativa deve confrontare il sistema con il fatto, deve analizzare si la soluzione è corretta per il problema. La norma, pertanto, non può essere compressa fuori della società e la rilevanzia della società civile non può essere valutata separatamente della norma. La coesistenza degli individui nella società rapresenta la ragion d'essere del diritto e della norma.

Spetta all'interprete, dunqui, trovar la filosofia che è il fondamento dell'ordinamento de determinata società. La teoria dell'ordinamento deve corrispondere al momento storico-giuridico e al principio vigente di legalità. Non ha una teoria 
dell'ordinamento astratta e generale, valida per tutti i tempi e luoghi. Così, é necessario sapere o che è stato possibile da fare nell'ordinamento, concretamente.

La scienza giuridica si caratteriza per il confronto tra norma e fatto, che si configura in forme diverse, secondo alcune variabili storice. Quindi, l' attività del giurista non è predeterminata e rigida, ma deve avere una conoscenza globale dell'ordinamento, che è interdisciplinare con le altre scienze sociali. Se é necessario fare leggi adequate è altrettanto necessario formare giuristi che abbiano la sensibilitá di interpretare, conoscere la realità e individuare la normativa da applicare.

L' autore anche analizza i diffeti nell'interpretazioni unilaterali, che non sono adeguate a ravvisare nel sistema giuridico una unitarietà culturale. Sono exempi dell'interpretazioni unilaterali il formalismo, il sostansialismo, il sociologismo, il pragmatismo e il politicismo. Il giurista, pertanto, deve fornire la conoscenza dell'ordinamento e la sua utilizzazione nella società, e non può esprimere la sua personalità.

Da ultimo, Pietro Perlingieri descrive alcuni cause per la crisi dello Stato sociale di diritto, che rappresenta il tentativo di coniugare legalità e giustizia sociale, attraverso la protezione della libertà negative (limitazioni di sovranità dello Stato nei confronti dell'individuo) e della libertà positiva (prestesa dei citadini ad una serie di prestazioni da parte dello Stato). La crisi si verifica con lo smarrimento culturale e del senso civille della legalità e della guistízia. Le ragioni sono molteplici: la doutrina non elabora tecniche adeguate, il legislatore non sempre ha atuato coerentemente i princípi costitucionali e la magistratura non ha saputo offrire una elaborazione attuativa dei valori costitucionali.

\section{GLOSSÁRIO}

- Atteggiamenti - atitudes

- Benessere - bem estar

- Canoni - preceitos

- Compiere - ter lugar

- Compito - tarefa

- Consapevolezza - consciência

- Esigono - exigência

- Fisse - fixa

- Pace - passo

- Pregnante - carregada

- Quasi che - como se

- Raggiunge - atinge 
- Ravvisare - reconhecer

- Rilievo - alívio

- Rinsaldare - fortalecer

- Rinunciatari - desistências

- Rinvenire - descobrir, reencontrar

- Ruolo- papel, posto, cargo

- Scettici - céticos

- Sfocia - causa

- Smarrimento - perda

- Sorgere - avistar

- Spettare - caber a, competir a

- Velleità - ambições

- Vicenda - acontecimento 